\title{
ECONOMICS
}

\section{THE BIG MAC INDEX TWO DECADES ON AN EVALUATION OF BURGERNOMICS}

\author{
by
}

Kenneth W Clements

\author{
Yihui Lan
}

and

Shi Pei Seah

\author{
Business School \\ The University of Western Australia
}

DISCUSSION PAPER $\mathbf{1 0 . 1 4}$ 


\title{
THE BIG MAC INDEX TWO DECADES ON AN EVALUATION OF BURGERNOMICS*
}

\author{
by \\ Kenneth W. Clements \\ Yihui Lan \\ and \\ Shi Pei Seah \\ Business School \\ The University of Western Australia
}

\begin{abstract}
The Big Mac Index, introduced by The Economist magazine more than two decades ago, claims to provide the "true value" of a large number of currencies. This paper assesses the economic value of this index. We show that (i) the index suffers from a substantial bias; (ii) once the bias is allowed for, the index tracks exchange rates reasonably well over the medium to longer term in accordance with relative purchasing power parity theory; (iii) the index is at least as good as the industry standard, the random walk model, in predicting future currency values for all but shortterm horizons; and (iv) future nominal exchange rates are more responsive than prices to currency mispricing. While not perfect, at a cost of less than \$US10 per year, the index seems to provide good value for money.
\end{abstract}

\footnotetext{
${ }^{*}$ We would like to acknowledge the excellent research assistance of Grace Gao, Ze Min Hu, Callum Jones and Tom Simpson, and helpful comments from Aimee Kaye, Geoffrey Kingston and seminar participants at UWA and the Economic Measurement Group Workshop, Centre for Applied Economic Research, UNSW. This research was supported in part by the ARC, ACIL Tasman, AngloGold Ashanti, WA Department of Industry and Resources and the Business School, The University of Western Australia. The views expressed herein are not necessarily those of the supporting bodies.
} 


\section{Introduction}

In 1972, just prior to the collapse of the Bretton-Woods system of fixed exchange rates, the US dollar cost about 40 British pence. By 1985, the dollar had appreciated to 90 pence, but by the end of December 2008 it had fallen back to 67 pence. As such substantial changes in currency values over the longer term are commonplace in a world of floating exchange rates, understanding the valuation of currencies is a significant intellectual challenge and of great importance for economic policy, the smooth functioning of financial markets, and the financial management of many international companies.

While exchange-rate economics is a controversial area, a substantial body of research now finds that over the longer term exchange rates are "anchored" by price levels. This idea is embodied in purchasing power parity (PPP) theory, which states that the exchange rate is proportional to the ratio of price levels in the two countries. To illustrate, Figure 1.1 uses annual data to plot the exchange rate (relative to the US dollar) of the United Kingdom and Japan and the ratio of their price level to that of the US. British prices increased relative to those in the US over the past 30 years, while those of Japan decreased. According to PPP theory, the British pound should have depreciated (an increase in the pound cost of the dollar), and the Japanese yen should have appreciated. This is what in fact happened. Even though at times the exchange rate deviates substantially from the price ratio, there is a distinct tendency for this ratio to play the role of the underlying trend, or anchor, for the exchange rate. That is to say, while the exchange rate meanders around the price ratio, over time it has a tendency to revert to this trend value, so the ratio can be thought of as the "underlying value" of the currency. Figure 1.1 thus provides some prima facie evidence in favour of PPP over the long term.

A new and simple way of making PPP comparisons was introduced in 1986 by The Economist magazine. This involves using the price of a Big Mac hamburger at home and abroad as the price ratio that reflects the underlying value of the currency. This price ratio is known as the "Big Mac Index" (BMI), which forms the basis for "burgernomics". When compared to the actual exchange rate, the BMI purports to give an indication of the extent to which a currency is over- or undervalued according to the law of one price. "[Seeking] to make exchange-rate theory more digestible" (The Economist, $9^{\text {th }}$ April 1998), the Index has been published over a lengthy period for an increasing number of currencies (now more than 40) and is claimed to be a successful new product from a number of perspectives. In the words of The Economist: 
The [Big Mac] Index was first served up in September 1986 as a relatively simple way to calculate the over- and under-valuation of currencies against the dollar. It soon caught on. Such was its popularity that it was updated the following January, and has now become the best-known regular feature in The Economist. ${ }^{1}$

In an instructive metaphor, The Economist (26 ${ }^{\text {th }}$ August 1995) describes the approach underlying the $\mathrm{BMI}$ in the following terms:

Suppose a man climbs five feet up a sea wall, then climbs down twelve feet. Whether he drowns or not depends upon how high above sea-level he was when he started. The same problem arises in deciding whether currencies are under- or over-valued."

The current exchange rate is analogous to the position of the man on the sea wall and the PPP rate is the sea-level, so that whether the currency is correctly priced by the market is determined by reference to its PPP value. The identification of the PPP value of a currency with the sea-level also accords with the idea that "water finds its own level", so that over time the currency should tend to revert to its PPP value. While an informal currency pricing model, the BMI is rooted in PPP theory and provides a fascinating example of the productive interplay between fundamental economic research, journalism and financial markets.

The literature on PPP in general is large and growing, and several good surveys are available, including Froot and Rogoff (1995), Lan and Ong (2003), MacDonald (2007), Rogoff (1996), Sarno and Taylor (2002), Taylor and Taylor (2004) and Taylor (2006). Early contributors to academic research on the BMI include Annaert and Ceuster (1997), Click (1996), Cumby (1996), Ong (1997) and Pakko and Pollard (1996), while more recent papers include Chen et al. (2005), Clements and Lan (2010), Lan (2006) and Parsley and Wei (2007); a comprehensive review of the burgernomics literature is provided later in the paper. As a way of illustrating professional interest in PPP, we conducted a keyword search for the term "purchasing power parity" or "PPP" in Factiva. $^{2}$ As a basis for comparison, we also searched for four broad economic terms -- "inflation", "unemployment", "interest rate" and "exchange rate" -- and another relatively narrow term, "foreign direct investment" (or "FDI"), together with the "Big Mac Index". Figure 1.2 plots on the left-hand axis the number of articles published on each topic in each of the past three decades. As this axis uses a logarithmic scale, the change in the height of the bars from one decade to the next indicates

\footnotetext{
${ }^{1}$ From "Ten Years of the Big Mac Index", published on The Economist web site (http://www.economist.com, consulted 14 July 1999). The Economist also publishes other similar PPP gauges. The "Coca-Cola map" appeared in the magazine in 1997 and shows a strong positive correlation between per capita consumption of Coke in a country and that country's quality of life. In 2004, the "Tall Latte Index" was proposed, which is based on the price of a cup of Tall Latte coffee at Starbucks in more than 30 countries. This index provides roughly similar, albeit not identical, results to the BMI. Inspired by such single-good indices, other institutions have devised similar measures, such as the "iTunes Index" featured in Business Review Weekly, an Australian business magazine, in August 2006, and the "iPod Index" compiled by CommSec Australia in January 2007 (James, 2007a, b).

${ }^{2}$ For an earlier analysis along these lines, see Lan (2002).
} 
the exponential rate of growth for each topic. The right-hand vertical axis gives the average growth rate, on an annual basis, for each topic. It can be seen that PPP has grown at an average annual rate of about 25 percent p.a., which ranks immediately below that of foreign direct investment, while the BMI has almost the same growth rate as FDI of 32 percent. Thus while the number of articles on PPP and the BMI are still smaller than the four broader areas, this topic is clearly of substantial professional importance and growing rapidly.

As the BMI is now a mature product, a broad evaluation of its workings and performance is appropriate. We show that although it is not perfect, the Index offers considerable insight into the operation of currency markets. In Section 2, we set the scene by discussing PPP theory in some detail. Then follows in Section 3 an account of the workings of the BMI, where it is established that it is subject to serious bias. Once the Index is adjusted for this bias, we show in Section 4 that exchange rates tend to revert to the mean, roughly speaking, after a period of about 4 years. Section 5 examines the predictive ability of the BMI and establishes that over (under) -valued currencies subsequently depreciate (appreciate). How this effect is split between a future change in the nominal rate and inflation is discussed in Sections 6 and 7. The possible role of the United States dollar in generating common shocks to all other currencies is explored in Section 8. Section 9 contains a survey of the literature on burgernomics and concluding comments are given in Section 10.

\section{Three Versions of PPP}

This section gives an account of PPP theory by presenting the three versions: Absolute, relative and stochastic. This material provides the theoretical underpinnings for the remainder of the paper.

Let $\mathrm{P}_{\mathrm{i}}$ denote the domestic price of good $\mathrm{i}$ in terms of domestic currency and $\mathrm{P}_{\mathrm{i}}^{*}$ the price of the same good in the foreign country in terms of foreign currency. With zero transaction costs and no barriers to international trade, arbitrage equalises the cost of the good expressed in terms of a common currency:

$$
\mathrm{P}_{\mathrm{i}}=\mathrm{SP}_{\mathrm{i}}^{*}
$$

where $\mathrm{S}$ is the spot exchange rate (the domestic currency cost of a unit of foreign currency). Equation (2.1) is known as the law of one price. The $2 \times 2$ structure of prices can be summarised as follows: 


\begin{tabular}{lcc}
\multirow{2}{*}{ Currency } & \multicolumn{2}{c}{ Location } \\
\cline { 2 - 3 } Home & Home & Foreign \\
Foreign & $\mathrm{P}_{\mathrm{i}}$ & $\mathrm{SP}_{\mathrm{i}}^{*}$ \\
& $\mathrm{P}_{\mathrm{i}} / \mathrm{S}$ & $\mathrm{P}_{\mathrm{i}}^{*}$ \\
\hline
\end{tabular}

As prices in a given row are expressed in terms of the same currency, they are comparable "rowwise", not "column-wise".

Further, let $\mathrm{w}_{\mathrm{i}}$ and $\mathrm{w}_{\mathrm{i}}^{*}$ denote the share of good $\mathrm{i}$ in the economy at home and abroad, with $\sum_{\mathrm{i}=1}^{\mathrm{n}} \mathrm{w}_{\mathrm{i}}=\sum_{\mathrm{i}=1}^{\mathrm{n}} \mathrm{w}_{\mathrm{i}}^{*}=1$, where $\mathrm{n}$ is the number of goods. Then, multiplying both sides of equation (2.1) by $\mathrm{w}_{\mathrm{i}}$ and summing over $\mathrm{i}=1, \ldots, \mathrm{n}$, we obtain

$$
\sum_{\mathrm{i}=1}^{\mathrm{n}} \mathrm{w}_{\mathrm{i}} \mathrm{P}_{\mathrm{i}}=\mathrm{S} \sum_{\mathrm{i}=1}^{\mathrm{n}} \mathrm{w}_{\mathrm{i}} \mathrm{P}_{\mathrm{i}}^{*}
$$

As the left-hand side of this equation is a share-weighted average of the $\mathrm{n}$ prices at home, it is interpreted as a price index, which we write as $\mathrm{P}=\sum_{\mathrm{i}=1}^{\mathrm{n}} \mathrm{w}_{\mathrm{i}} \mathrm{P}_{\mathrm{i}}$. But as the right-hand side of the above equation applies domestic weights to foreign prices, it is not a conventional price index. To make some progress, we need the simplifying assumption that the foreign and domestic weights coincide, so that $\sum_{\mathrm{i}=1}^{\mathrm{n}} \mathrm{w}_{\mathrm{i}} \mathrm{P}_{\mathrm{i}}^{*}=\sum_{\mathrm{i}=1}^{\mathrm{n}} \mathrm{w}_{\mathrm{i}}^{*} \mathrm{P}_{\mathrm{i}}^{*}=\mathrm{P}^{*}$, an index of the price level abroad. Thus we have

$$
\mathrm{P}=\mathrm{SP}^{*},
$$

which is an economy-wide version of condition (2.1). We can interpret $\mathrm{P}$ as the domestic currency cost of a basket of goods at home, while $\mathrm{P}^{*}$ is the cost of the same basket abroad. Thus, SP converts this foreign currency cost into domestic currency units and the ratio $\mathrm{P} /\left(\mathrm{SP}^{*}\right)$ is a measure of the relative price of the two baskets. Expressing equation (2.2) as $\mathrm{S}=\mathrm{P} / \mathrm{P}^{*}$, we obtain the absolute version of PPP, whereby the exchange rate is the ratio of domestic to foreign prices. Using lowercase letters to denote logarithmic values of variables, we obtain

$$
\mathrm{s}=\mathrm{p}-\mathrm{p}^{*} \text {. }
$$

Writing $\mathrm{r}=\mathrm{p}-\mathrm{p}^{*}$ for relative prices, the above can be expressed as $\mathrm{s}=\mathrm{r}$.

Next, we define the home country's real exchange rate as

$$
\mathrm{q}=\log \frac{\mathrm{P}}{\mathrm{SP}^{*}}
$$

which is the logarithmic relative price of the two baskets. According to absolute PPP, the real exchange rate $\mathrm{q}=\mathrm{p}-\mathrm{s}-\mathrm{p}^{*}=\mathrm{r}-\mathrm{s}=0$, and is constant. When $\mathrm{q}>0$, prices at home are too high 
relative to those abroad, and the currency is said to be "overvalued in real terms", and vice-versa. If there is a tendency for the real rate to revert to it PPP value, a non-zero value of q signals some form of disequilibrium, calling for future readjustments of prices and/or the exchange rate.

Before proceeding, it is worthwhile to emphasise the restrictive conditions under which absolute parity holds. The assumption of zero transport costs and other barriers to trade rules out a "wedge" between foreign and domestic prices. It also serves to exclude from PPP considerations all non-traded goods, those goods that do not enter into international trade due to prohibitive transport costs. As in a developed economy non-traded goods constitute something like 70 percent of GDP, their exclusion would seem to limit drastically the applicability of PPP theory, at least in its absolute form. Below, we return to transport costs and in the next section, we return to the related issue of non-traded goods. A further restrictive condition underlying PPP is the assumption that the market basket associated with the price index is identical in the two countries.

We now present a geometric exposition of PPP theory. The left graph of Panel A of Figure 2.1 presents the absolute PPP relationship, which is a 45-degree line passing through the origin. As this PPP line has a unit slope, any combination of $s$ and $r$ that lies on the line satisfies $s=r$, so that the real exchange rate $q=r-s=0$. On this PPP line, an increase in the relative price from $r_{1}$ to $r_{2}$, for example, leads to an equi-proportional depreciation of the nominal exchange rate $s$, as is illustrated by the movement from point $A$ to $B$, whereby $s_{2}-s_{1}=r_{2}-r_{1}$. The PPP ray acts as a boundary that divides up the exchange-rate/price space into two regions of mispricing. As shown on the righthand graph of Panel A, points above the ray indicate an undervaluation of the home-country currency $(q<0)$, where $s$ is too high and/or $r$ is too low. In this region, the price of the domestic basket $(\mathrm{P})$ is below that of the foreign basket $\mathrm{SP}^{*}$. Conversely, points below the PPP ray represent an overvalued domestic currency $(q>0)$. Only at the boundary between these two regions is the currency correctly priced $(q=0)$.

Let us now consider transport costs and any other barriers to the free flow of goods across borders that inhibit the equalisation of prices. With transport costs and other barriers, rather than having equation (2.1), we now have a generalisation $P_{i}=S\left(1+T_{i}\right) P_{i}^{*}$, where $T_{i}$ measures the proportionate wedge between domestic and foreign prices, which for short we term "transport costs". If these costs are approximately constant over time, then

$$
\hat{\mathrm{P}}_{\mathrm{i}}=\hat{\mathrm{S}}+\hat{\mathrm{P}}_{\mathrm{i}}^{*}
$$


where a circumflex (“^”) represents relative change $(\hat{\mathrm{x}}=\mathrm{dx} / \mathrm{x})$. Equation (2.5) represents a weaker version of the law of one price as it is formulated in terms of changes not levels. We can then weight as before and aggregate over goods to obtain

$$
\hat{\mathrm{P}}=\hat{\mathrm{S}}+\hat{\mathrm{P}}^{*}
$$

where $\hat{\mathrm{P}}=\sum_{\mathrm{i}=1}^{\mathrm{n}} \mathrm{w}_{\mathrm{i}} \hat{\mathrm{P}}_{\mathrm{i}}$ is the change in the cost of the basket of goods at home and $\hat{\mathrm{P}}^{*}$ is the corresponding change for the foreign country. As these measures are share-weighted averages of the (infinitesimal) changes in the $\mathrm{n}$ individual prices, they are interpreted as Divisia price indexes. Integrating equation (2.6) we obtain $\mathrm{P}=\mathrm{KSP}^{*}$, where $\mathrm{K}$ is a constant of integration, or in logarithmic form

$$
\mathrm{s}=\mathrm{p}-\mathrm{p}^{*}-\mathrm{k}
$$

This is the relative version of PPP. As $\hat{x}=d x / x=d(\log x)$, equation (2.7) implies

$$
\hat{\mathrm{S}}=\hat{\mathrm{P}}-\hat{\mathrm{P}}^{*}
$$

where $\hat{\mathrm{P}}$ and $\hat{\mathrm{P}}^{*}$ are interpreted as inflation at home and abroad, respectively. In words, the proportionate change in the exchange rate is equal to the inflation differential. Thus high-inflation countries experience depreciating currencies and vice-versa, which is the open-economy version of the quantity theory of money. It is to be noted that equation (2.8) is just a rearrangement of equation (2.6). Note also that relative PPP expressed in (2.7) includes absolute PPP as a special case where $\mathrm{k}$ $=0$, or $\mathrm{K}=1$ in $\mathrm{P}=\mathrm{KSP}^{*}$. To summarise, relative parity implies that the exchange rate is proportional to the price ratio, with the factor of proportionality not necessarily equal to unity. Under absolute parity, the proportionality factor is unity so that the exchange rate equals the price ratio. $^{3}$

Geometrically, under relative PPP the relationship between $\mathrm{s}$ and the relative price $\mathrm{r}=\mathrm{p}-\mathrm{p}^{*}$ is a straight line of the form $\mathrm{s}=\mathrm{r}-\mathrm{k}$, which is presented on the left graph of Panel B of Figure 2.1. Along this line, the real exchange rate is $\mathrm{q}=\mathrm{r}-\mathrm{s}=\mathrm{k}$, which is constant. This relative PPP line also has a unit slope, but an intercept $-\mathrm{k} \neq 0$. Again, as we move up the line from $\mathrm{A}$ to $\mathrm{B}$, an increase in the relative price still leads to an equiproportional depreciation in the nominal exchange rate, so that $s_{2}-s_{1}=r_{2}-r_{1}$. As before, points above the relative PPP line correspond to an undervaluation of the domestic currency $(q-k<0)$ and those below the line correspond to an overvaluation $(q-k>0)$,

\footnotetext{
${ }^{3}$ A further issue about the distinction between absolute and relative PPP should be noted. Almost invariably statistical agencies publish information on the cost of a basket of goods in the form of a price index that has an arbitrary base, which determines the proportionality constant K. Such indexes can only be used for calculations of relative parity, not absolute.
} 
but in comparison with absolute PPP, the boundary between the two regions is now "vertically displaced", as indicated by the graph given on the right-hand side of Panel B in Figure 2.1.

Panel C for Figure 2.1 gives the case of stochastic PPP. ${ }^{4}$ If we denote the stochastic deviation from relative parity by e with $\mathrm{E}(\mathrm{e})=0$ and variance $\sigma^{2}$, the real exchange rate is then the random variable $\mathrm{q}=\mathrm{k}-\mathrm{e}$ with $\operatorname{var}(\mathrm{q})=\sigma^{2}>0$, so that $\mathrm{q}$ is obviously not constant. Initially, suppose for simplicity that $\mathrm{e}$ is a discrete random variable and that $\mathrm{e}_{1}<0$ and $\mathrm{e}_{2}>0$ are its only possible values. When the shock is $e_{1}<0$, we obtain a new, lower 45 -degree line, $s=-k+e_{1}+r$, which has an intercept of $-\mathrm{k}+\mathrm{e}_{1}$; similarly, $\mathrm{e}_{2}>0$ results in the upper line on the left graph of Panel C. Consider the situation in which $\underline{s}$ is the exchange rate and $r_{1}$ is the relative price, so that we are located at the point $\mathrm{W}$ on the left graph of Panel C. If there is now the same increase in the relative price as before, so that $r$ rises from $r_{1}$ to $r_{2}$, then, in the presence of the shock $e_{1}$, we move from $\mathrm{W}$ to the point $\mathrm{X}$ with the rate depreciating to $\mathrm{s}_{0}$. But if the shock is $e_{2}$, the same relative price $\mathrm{r}_{2}$ leads to an exchange rate of $\overline{\mathrm{s}}$, as indicated by the point $\mathrm{Y}$. More generally, if relative prices change within the range $\left[r_{1}, r_{2}\right]$ and if the shocks can now vary continuously within the range $\left[e_{1}, e_{2}\right]$, then the exchange-rate/relative-price points lie somewhere in the shaded parallelogram WXYZ. Thus, the relationship between the exchange rate and prices is $\mathrm{s}=\mathrm{r}-\mathrm{k}+\mathrm{e}$, which is the stochastic version of PPP. Due to the random shocks e, the exchange rate and prices are no longer proportionate. It is to be noted that the height of the shaded parallelogram exceeds its base, which accords with the idea that exchange rates are much more volatile than prices in the short run (Frenkel and Mussa, 1980). However in the long run, as $\mathrm{E}(\mathrm{e})=0$ and thus $\mathrm{E}(\mathrm{s})=\mathrm{r}-\mathrm{k}$, relative PPP holds and the expected value of the real exchange rate $\mathrm{E}(\mathrm{q})=\mathrm{k}$ is constant. Here, $\mathrm{k}$ is the long-run, or equilibrium, value of the real exchange rate.

Therefore in the case of stochastic PPP, the real exchange rate $\mathrm{q}$ is not constant and fluctuates around $\mathrm{k}$, so that exchange rates and prices are scattered around the 45-degree line. This is in contrast to relative PPP, in which $\mathrm{q}$ is a constant value for any combination of $\mathrm{s}$ and $\mathrm{r}$ and all $(\mathrm{s}, \mathrm{r}$ ) pairs locate exactly on the 45-degree line. In other words, stochastic PPP means that there exists a "neutral band" around the 45-degree line that contains values of the exchange rate and prices that identify the currency as being "correctly priced". Under relative PPP, these points are interpreted as deviations from parity. Obviously, the width of the band is the key to this approach: if it is

\footnotetext{
${ }^{4}$ For an earlier rendition of stochastic PPP, see Lan (2002). For related work, see MacDonald and Stein (1999). Note also that MacDonald (2007, p. 42) considers PPP within an environment in which there are transaction costs in moving goods from one country to another. According to this broader version of PPP, there exists a "neutral band" within which exchange rates and prices can fluctuate.
} 
sufficiently wide, then all possible configurations of exchange rates and prices would be contained in the band, and the approach would be vacuous. On the other hand, if the band is sufficiently narrow, all observations would locate outside it, and the approach would always be rejected. One way to strike a balance between the "too wide" and "too narrow" band problems is to proceed probabilistically.

Consider the probability distribution of the real exchange rate $q$ with $\mathrm{E}(\mathrm{q})=\mathrm{k}$ and $\operatorname{var}(q)=\sigma^{2}$. We commence with the symmetric case in which the probability of the exchange rate being undervalued $(\mathrm{q}-\mathrm{k}<0)$ is $\alpha / 2$ and the same $\alpha / 2$ is the probability of the currency being overvalued $(q-k>0)$, where $0<\alpha<1$. In other words, we can interpret $\alpha / 2$ as the mass in each tail of the distribution, so that our task is to characterise the location of the tails. According to Chebyshev's inequality

$$
\operatorname{Pr}(|\mathrm{q}-\mathrm{k}|>\mathrm{c}) \leq \frac{\sigma^{2}}{\mathrm{c}^{2}}
$$

where $\mathrm{c}$ is a positive constant. We interpret $\mathrm{c}$ as defining the boundary, so that $\alpha=\sigma^{2} / \mathrm{c}^{2}$, or $\mathrm{c}=\sqrt{\sigma^{2} / \alpha}$. Thus, the lower bound is $\mathrm{k}-\sqrt{\sigma^{2} / \alpha}$ and the upper bound is $\mathrm{k}+\sqrt{\sigma^{2} / \alpha}$. The region of correct pricing is indicated in the area between the lines DD' and FF' on the right graph of Panel C, which is defined by

$$
\mathrm{k}-\underline{\mathrm{z}} \leq \mathrm{q} \leq \mathrm{k}+\overline{\mathrm{z}}
$$

where $\underline{\mathrm{z}}=\overline{\mathrm{z}}=\sqrt{\sigma^{2} / \alpha}$. The points above the line DD', which correspond to the case $\mathrm{q}<\mathrm{k}-\underline{\mathrm{z}}$, indicate that the currency is undervalued, while points below the line $F^{\prime}(q>k+\bar{z})$ identify overvaluation. Statistically, if we have a number of observations on $\mathrm{q}, \alpha \times 100$ percent of these would lie outside the band and the remaining $(1-\alpha) \times 100$ percent inside it. In the above situation, the deviations are symmetric around the mean, so that there are equal probabilities of currency undervaluation and overvaluation and $\underline{z}=\bar{z}$. In the more general case, the distribution of $q$ is asymmetric and the long-run relative PPP line, EE', does not lie mid-way between the two boundaries $\mathrm{DD}^{\prime}$ and $\mathrm{FF}^{\prime}$.

The above analysis does not hinge on q following any particular probability distribution -- it is distribution free. If we have information on the form of the distribution, then this additional information can be used to tighten the neutral band. Consider for the purpose of illustration the case of the normal distribution whereby $\mathrm{q} \sim \mathrm{N}\left(\mathrm{k}, \sigma^{2}\right)$ and $\alpha=0.05$. Under normality 


$$
\operatorname{Pr}\left[-1.96<\frac{\mathrm{q}-\mathrm{k}}{\sigma}<1.96\right]=1-\alpha=0.95,
$$

so that the neutral band for $\mathrm{q}$ is $[\mathrm{k}-1.96 \sigma, \mathrm{k}+1.96 \sigma]$. Contrast the width of this band with that implied by the Chebyshev's inequality, expression (2.9). With $\alpha=0.05$ as before, we have $\underline{\mathrm{z}}=\overline{\mathrm{z}}=\sqrt{\sigma^{2} / \alpha}=\sqrt{20} \sigma=4.47 \sigma$, so that the neutral band is $[\mathrm{k}-4.47 \sigma, \mathrm{k}+4.47 \sigma]$. Thus the width of the band under normality is $2 \times 1.96 \sigma$, while under Chebyshev's inequality, it is $2 \times 4.47 \sigma$, so that the additional information that the distribution is normal results in a shrinkage of the band width by about 50 percent.

It is worth noting that this approach to currency valuation resembles hypothesis testing. To see this, imagine the existence of an unknown "true" state of the world in which the currency is either correctly or incorrectly priced, and we observe only whether or not the exchange-price configuration is located within the neutral band. There are four possible outcomes of the application of the approach:

(i) When the currency is in fact correctly priced and stochastic PPP identifies this situation accurately, i.e., the $(s, r)$ point is located in the neutral band. As the inference is correct, the procedure works satisfactorily.

(ii) When the currency is in fact correctly priced, but stochastic PPP yields the conclusion that it is undervalued or overvalued. There is an $\alpha \times 100$ percent probability of this incorrect inference being drawn, which is analogous to a Type I error.

(iii) When the currency is in fact incorrectly priced, but stochastic PPP indicates that the currency is correctly priced. This is similar to the case of a Type II error.

(iv) When the currency is in fact incorrectly priced, and stochastic PPP accurately indicates that the currency is incorrectly priced. In this situation, the correct inference is drawn.

The above taxonomy is summarised in the following table: 


\begin{tabular}{lcc}
\multirow{2}{*}{ True currency pricing } & \multicolumn{2}{c}{ Does $(\mathrm{s}, \mathrm{r}$ ) lie in the neutral band? } \\
\cline { 2 - 3 } & Yes & No \\
\hline Correct & Reliable inference & Type I error \\
Incorrect & Type II error & Reliable inference \\
\hline
\end{tabular}

To conclude this section, consider an arbitrary combination of $\mathrm{s}$ and $\mathrm{r}$, which is represented by the same point $\mathrm{C}$ in all three right-hand graphs of Figure 2.1. As $\mathrm{C}$ lies above the PPP ray in Panels A and B, both absolute and relative PPP indicate that the currency is undervalued. However, according to stochastic PPP (Panel C), the currency is correctly priced as the point $\mathrm{C}$ lies within the neutral band. This situation is likely to be frequently encountered in practice with many apparent departures from parity simply associated with the inherent volatility of currency markets. For example, some departures may be insufficient to justify the costs of moving goods internationally and/or taking a currency position, especially if they are expected to soon reverse themselves. Therefore, to value a currency, it is crucial that the proper distinction be made between the three versions of PPP.

\section{The Workings of the Big Mac Index}

The previous section highlighted the restrictive conditions under which absolute parity holds, viz., (i) the absence of barriers to international trade, which also rules out nontraded goods; and (ii) identical baskets underlying the price indexes in the home and foreign countries. The weaker condition of relative PPP largely avoids the first problem, which accounts for its more frequent use in practice, but the problem of identical baskets remains. Surprisingly, the Big Mac Index (BMI) uses absolute parity in the context of a single-good basket, a Big Mac hamburger. In this section, we illustrate the workings of the BMI and, as it purports to have much to say about the workings of the real-world currency markets, we assess how the Index deals with the above two restrictive conditions and how it performs in practice.

Though just a single good, a McDonald's Big Mac hamburger has a variety of tradable ingredients such as ground beef, cheese, lettuce, onions, bread, etc., and non-tradable ingredients such as labour, rent, and electricity, as well as other ingredients such as cooking oil, pickles and sesame seeds. By estimating the Big Mac cost function using the prices of the various ingredients, Parsley and Wei (2007) recover the recipe in "broad" basket form. They find that the shares of important ingredients are: 


\begin{tabular}{lrr} 
Ingredient & Cost share (\%) \\
\hline Tradable & & \\
Beef & 9.0 & \\
Cheese & 9.4 & \\
Bread & $\underline{12.1}$ & 30.5 \\
Nontradable & 45.6 & \\
Labour & 4.6 & \\
Rent & $\underline{5.1}$ & 55.3 \\
Electricity & & $\underline{14.2}$ \\
Other & & 100.0 \\
Total & &
\end{tabular}

We can thus regard the price of a Big Mac as being the cost of a basket of inputs, just like P of the previous section is the cost of a market basket of goods. By comparing the price of a Big Mac in the US and other countries, The Economist magazine judges whether currencies are correctly priced based on the idea that a Big Mac should cost the same everywhere around the world when using a common currency. As the basket associated with the prices can be considered almost identical in the home and foreign countries, the BMI cleverly avoids problem (ii) above associated with absolute PPP. But as transport costs and other trade barriers are not allowed when comparing prices, this is an application of absolute PPP.

As discussed in the previous section, the arbitrage foundation of absolute parity applies to traded goods only. But non-traded goods prices can also be related across countries for at least two reasons. First, if there is substitution between traded and nontraded goods in production and consumption, then in a broad class of general equilibrium models, the change in the price of nontraded goods $\left(\hat{\mathrm{P}}_{\mathrm{N}}\right)$ is a weighted average of the changes in the prices of importables and exportables $\left(\hat{\mathrm{P}}_{\mathrm{M}}, \hat{\mathrm{P}}_{\mathrm{X}}\right): \hat{\mathrm{P}}_{\mathrm{N}}=\omega \hat{\mathrm{P}}_{\mathrm{M}}+(1-\omega) \hat{\mathrm{P}}_{\mathrm{X}}$, where $0 \leq \omega \leq 1$. Thus if nontraded goods are good substitutes for importables, the weight $\omega$ is large, so that the relative price $\mathrm{P}_{\mathrm{N}} / \mathrm{P}_{\mathrm{M}}$ is approximately constant, while a large value of $1-\omega$ implies $\mathrm{P}_{\mathrm{N}} / \mathrm{P}_{\mathrm{X}}$ is approximately constant (see Sjaastad, 1980, for details). Provided the weight $\omega$ is approximately the same at home and abroad, if PPP equalises the prices of traded goods across countries, then there is at least a tendency for the same to be true for their weighted average, the price of non-traded goods. However, as this link is based on substitution in production and consumption, it could possibly take some time for these relative price changes to work themselves through the economy and for there to be full adjustment.

A second mechanism that links prices of nontraded goods across countries is via expectations. If producers of non-traded goods know of the above link between their prices and those of traded goods, they may reasonably use it as a basis for their expectations. This could then 
mean that in setting prices, these producers employ as a short-cut the rule that they change their prices as soon as the exchange rate varies. An example is the plumber in Buenos Aires who puts up his prices as soon as the peso falls. This type of expectations mechanism may be quite rapid in its operation. These two arguments provide a rationale for the inclusion of elements of the cost of nontraded goods in PPP calculations, such as the Big Mac Index.

Figure 3.1 reproduces the Big Mac article published in The Economist of $26^{\text {th }}$ July 2008 . As can be seen from column 4 of the table, the implied PPP of the dollar is just the ratio of the domestic Big Mac price in domestic currency (column 2) to that in the US in terms of dollars (first entry in column 2). This ratio is the purchasing power of one US dollar in terms of Big Macs. However, the actual exchange rate, presented in column 5, may not be the same as this PPP exchange rate. Column 6 is the percentage difference between the PPP exchange rate and the actual exchange rate, a positive (negative) value of which indicates over (under) -valuation of a currency. An overvalued currency indicates that domestic prices are higher than foreign prices $\left[\mathrm{P} /\left(\mathrm{SP}^{*}\right)>1\right]$, and vice-versa. Take as an example Brazil, the fourth country from the top of the list in the table. The first and forth entries in column 2 of the table show that it costs US\$3.57 to buy a Big Mac in the US, and 7.50 reals in Brazil. Thus the implied PPP exchange rate is $7.50 / 3.57=2.10$, as indicated by the third entry of column 4. As the actual exchange rate is 1.58 (the cost of \$US1 in terms of the real), the Brazilian real is overvalued by $(2.10-1.58) / 1.58=+33$ percent (the third entry in column 6 of the table). Given the value of the real and US prices, Brazilian prices are too high, so that a movement towards parity would require some combination of a fall in Brazilian prices and a depreciation of the real.

Tables A1 and A2 of Appendix A1 contain the implied PPP exchange rates and nominal exchange rates of all countries that have their Big Mac data published at least once in $\underline{\text { The }}$ Economist since the inception of the Big Mac Index in 1986. Tables 3.1 and 3.2 are the companion tables for the 24 countries that have all data available over the period of 1994-2008; these data will be used in all computations that follow. In the previous paragraph, we showed that for Brazil in 2008 the BMI is as much as 33 percent above the market exchange rate. An element-by-element comparison of the third row of Table 3.1 with that of Table 3.2 reveals that there are similar large differences in most other years for this country. As will be discussed further below, the same problem of large deviations from parity occurs for most other countries. As under absolute parity these differences should be zero, this is not particularly encouraging for the proposition that BMI has economic content. 
One other feature of Tables 3.1 and 3.2 is worthy of note. The last columns of these tables give the coefficients of variations of the implied PPPs and exchange rates in each country, and Figure 3.2 is the associated scatter. The points corresponding to Brazil, Poland and Russia are located far away from those for the other countries, due to the volatility of monetary conditions in these countries associated with currency redenominations. The left panel of Figure 3.2 shows that in 17 out of the remaining 21 countries, as the points lie above the 45-degree line, the implied PPPs are less volatile than the corresponding exchange rates. This difference between the behaviour of exchange rates and prices was noted long ago by Frenkel and Mussa (1980) who attributed it to the essential distinction between the nature of asset and goods markets. The exchange rate is the price of foreign money and as such, behaves like the prices of other assets traded in deep, organised markets such as shares, bonds and some commodities. The determination of asset prices tends to be dominated by expectations concerning the future course of events. As expectations change due to the receipt of new information, which is unpredictable, the net result is that changes in asset prices themselves are largely unpredictable, giving rise to the substantial volatility of these prices. By contrast, goods prices tend to be determined in flow markets in which expectations play a much less prominent role. It is for this reason that goods prices tend to be more tranquil over time, reflecting changes in the familiar microeconomic factors of incomes, supply conditions, etc. The Big Mac data reflect this difference between the volatility of asset and goods prices.

Under PPP, $\mathrm{P}=\mathrm{SP}^{*}$, or $\mathrm{P} / \mathrm{SP}^{*}=1$. It is convenient to measure disparity logarithmically, so that for country $\mathrm{c}$ in year $\mathrm{t}$, we define $\mathrm{q}_{\mathrm{ct}}=\log \left(\mathrm{P}_{\mathrm{ct}} / \mathrm{S}_{\mathrm{ct}} \mathrm{P}_{\mathrm{t}}^{*}\right)$, as in equation (2.4) where we referred to this measure as the real exchange rate. This $\mathrm{q}_{\mathrm{ct}}$, when multiplied by 100 , is approximately the percentage difference between $\mathrm{P}_{\mathrm{ct}} / \mathrm{P}_{\mathrm{t}}^{*}$ and $\mathrm{S}_{\mathrm{ct}}$, the measure of disparity (or under- or overvaluation) used by The Economist (given in column 6 of the table in Figure 3.1). Under absolute PPP, $\mathrm{q}_{\mathrm{ct}}=0$. Table 3.3 and Figure 3.3 give $\mathrm{q}_{\mathrm{ct}}$ for each of the 24 countries over the 15 -year period and as can be seen, there are frequent departures from absolute PPP. Additionally, in the majority of countries $\mathrm{q}_{\mathrm{ct}}$ fluctuates substantially around its mean over the 15-year period; the exceptions to this general rule are Britain, China, and Hong Kong. One striking pattern is the one-sided nature of the disparities. Among the 24 countries under investigation, eight countries -- Australia, China, Hong Kong, Malaysia, Poland, Russia, Singapore and Thailand -- always have undervalued currencies. The currencies of Britain, Demark and Switzerland are always overvalued, while the Czech koruna, the Hungarian forint and the Mexican peso are undervalued in all but one year. Moreover, the Swedish krona is overvalued in all years except one. Thus for almost $8+3+3+1=15$ cases out of 
a total of 24, the BMI declares the currencies to be continuously (or almost continuously) over- or under-valued for each of the 15 years. These strings of persistent disparities over a fairly lengthy period in almost two-thirds of the cases raise serious questions about the credibility of the BMI as a pricing rule for currencies. To assess the current value of a currency, it would seem desirable for a robust pricing rule to appropriately incorporate past mispricing. The sustained nature of the departures from PPP, departures that are distinctly one-sided, means that past mispricing is ignored by the BMI. Below, we explore further this problem.

To test the significance of the pattern of deviations from parity, we employ two tests, one based on a contingency table and the other a runs test. Consider again the signs of successive pricing errors. If these errors are independent, then the probability of the currency being over- or under-valued in year $t+1$ is unaffected by mispricing in year $t$. To examine this hypothesis, in Table 3.4 we tabulate the mispricing for all currencies in all years, cross-classified by sign in consecutive years $t$ and $t+1$. As the observed $\chi^{2}$ value is 211.9 (given in the last entry of the last column of the table), we reject the hypothesis of independence on a year-on-year basis. Next, we repeat this test with the horizon extended from 1 year to $2,3, \ldots, 14$, and Table 3.5 reveals that independence is again rejected over most of these longer horizons regardless of whether or not overlapping observations are omitted.

Now consider a runs test. A run is a subsequence of consecutive numbers of the same sign, immediately preceded and followed by numbers of the opposite sign, or by the beginning or end of the sequence. If a currency is correctly priced, it is expected that the number of runs in the signs of the deviation is consistent with that of a random series. For example, the first row of Table 3.6 shows that for Argentina the signs of its $\mathrm{q}$ are ++++-+--------+ , which comprise five runs. If there are $\mathrm{T}$ observations and positive and negative values occur randomly, then the number of runs, $R$, is a random variable with mean $E(R)=\left(T+2 T_{+} T_{-}\right) / T$ and variance $\quad \operatorname{var} R=2 \mathrm{~T}_{+} \mathrm{T}_{-}\left(2 \mathrm{~T}_{+} \mathrm{T}_{-}-\mathrm{T}\right) / \mathrm{T}^{2}(\mathrm{~T}-1)$, where $\mathrm{T}_{+}$and $\mathrm{T}_{-}$are the total number of observations with positive and negative signs, respectively, with $\mathrm{T}_{+}+\mathrm{T}_{-}=\mathrm{T}$. Asymptotically, the distribution of $R$ is normal and the test statistic $Z=[R-E(R)] / \sqrt{\operatorname{var} R} \sim N(0,1)$. The results, given in Table 3.6, show that the null of randomness is rejected in a substantial number of countries. Although this result is subject to the qualification that this test has only an asymptotic justification, there seems to be considerable evidence against the hypothesis of randomness.

Next, we test whether or not the disparities are significantly different from zero, which amounts to a test of bias in the BMI. The shaded regions of Figure 3.3 are the two-standard-error 
bands for the mean exchange rates. These bands include zero only for Argentina, Chile, Japan and South Korea, so we can reject the hypothesis that $q=0$ for the remaining 20 countries. In Figure 3.4 we present the mean real exchange rates with countries grouped into four regions. This figure reveals that all currencies except those for the five high-income European regions/countries -- the Euro area, Britain, Sweden, Denmark and Switzerland -- are undervalued on average. It is notable that among the Asians, the currencies of China, Malaysia, Hong Kong and Thailand are all substantially undervalued. ${ }^{5}$ As exchange rates are expressed relative to the US dollar, some inferences about the value of the dollar can be drawn by averaging disparities over all non-dollar currencies, as is done in the third last row of Table 3.3. Thus we see that in 2008 on average the 24 currencies were undervalued by about 5 percent, which is equivalent to saying that the US dollar is overvalued by this amount. The value of the dollar over time is thus given by the entries of the third last row of Table 3.3 with the signs changed. Figure 3.5 plots these values of the dollar and as can be seen, it was most overvalued around 2001 and has been falling since then. The obvious qualification to this measure is that all 24 countries are equally weighted in valuing the dollar; more complex weighting schemes could be easily explored, but these would be unlikely to change the broad conclusion of an overvalued, but falling dollar.

Due to the 1997 Asian financial crisis, it is natural to divide the whole 15-year period into subperiods, before and after 1997, as in Table 3.7. There are two notable features here. (i) In the majority of countries, currencies become more undervalued (or less overvalued) following the Asian crisis. (ii) The changes in the means over the two periods are mostly significant. The results of testing the hypothesis that the real exchange rate is zero can be summarised as follows:

\begin{tabular}{lccc} 
& \multicolumn{3}{c}{ Period } \\
\cline { 2 - 4 } & $\begin{array}{c}1994-1997 \\
(\%)\end{array}$ & $\begin{array}{c}1998-2008 \\
(\%)\end{array}$ & $\begin{array}{c}1994-2008 \\
(\%)\end{array}$ \\
\hline Significantly positive & 29 & 21 & 21 \\
Significantly negative & 54 & 79 & 67 \\
Insignificant & 17 & 0 & 13 \\
\hline Total & 100 & 100 & 100
\end{tabular}

Thus, we see that sustained mispricing is almost the rule for the BMI. If the BMI is meant to play the role of the long-term, or equilibrium exchange rate, to which the actual rate is attracted, then an under- or overvaluation would signal subsequent equilibrating adjustments of the exchange rate and/or prices. But lengthy periods of substantial, sustained and significant mispricing demonstrate

\footnotetext{
${ }^{5}$ The productivity-bias hypothesis of Balassa (1964) and Samuelson (1964) says that the currencies of rich (poor) countries are over (under) -valued. While it is true that in Figure 3.4 the five countries (regions) with $q>0$ all have high incomes, countries with $\mathrm{q}<0$ include Canada, Australia, New Zealand, Hong Kong and Singapore, all of which should probably also be classified as rich. Thus the evidence in Figure 3.4 does not provide unambiguous support for the productivity-bias hypothesis.
} 
that such a mechanism is not at work. In a fundamental sense, the Big Mac Index fails, so that the Big Mac metric of currency mispricing cannot be taken at face value. In large part, the reason for this failure is that the BMI relies on absolute PPP, which ignores barriers to the international equalisation of prices. Fortunately, a simple modification to the BMI restores its predictive power, as is shown in the section after the next.

To summarise this section, we have established the following:

- The BMI uses the cost of a Big Mac hamburger as the metric for judging whether or not the currency is mispriced. As this product is made according to approximately the same recipe in all countries, the BMI avoids one of the major problems usually associated with absolute PPP. That problem is that the baskets underlying price indexes at home and abroad are likely to be substantially different, so that the ratio of the indexes reflects a combination of compositional disparities, as well as currency fundamentals.

- A well-known empirical regularity is that exchange rates are more volatile than prices. The Big Mac prices reflect this regularity.

- There are substantial, sustained and significant deviations of exchange rates from the BMI. The under- and over-valuations of currencies based on the BMI published by The Economist cannot be accepted as a reliable measure of mispricing. The BMI needs to be enhanced before it has substantial practical power.

\section{The Bias-Adjusted BMI and the Speed of Adjustment}

The above discussion implies that the BMI is a biased indicator of absolute currency values. Thus rather than absolute PPP holding in the form of $\mathrm{S}=\mathrm{P} / \mathrm{P}^{*}$, we have $\mathrm{S}=\mathrm{B}\left(\mathrm{P} / \mathrm{P}^{*}\right)$, where $\mathrm{B}$ is the bias, or $\mathrm{s}=\mathrm{b}+\mathrm{p}-\mathrm{p}^{*}$ in logarithmic terms. This, of course, is just relative PPP of Section 2 with $\mathrm{B}=1 / \mathrm{K}$ or $\mathrm{b}=-\mathrm{k}$. In this section, we analyse the extent to which the bias-adjusted BMI tracks exchange rates by formulating it in terms of changes over time, $\Delta \mathrm{s}=\Delta \mathrm{p}-\Delta \mathrm{p}^{*}$.

To proceed we have to specify the length of the horizon for exchange-rate and price changes. ${ }^{6}$ For any positive variable $\mathrm{X}_{\mathrm{t}}(\mathrm{t}=1, \ldots, \mathrm{T})$, define $\Delta_{(\mathrm{h})} \mathrm{X}_{\mathrm{t}}=\log \mathrm{X}_{\mathrm{t}}-\log \mathrm{X}_{\mathrm{t}-\mathrm{h}}$ as the logarithmic h-year change and $\Delta^{(\mathrm{h})} \mathrm{x}_{\mathrm{t}}=(1 / \mathrm{h}) \Delta_{(\mathrm{h})} \mathrm{x}_{\mathrm{t}}$ as the corresponding annualised change, $\mathrm{h}=1, \ldots, \mathrm{T}-1, \quad \mathrm{t}=\mathrm{h}+1, \ldots, \mathrm{T} . \quad$ As $\quad \Delta^{(\mathrm{h})} \mathrm{x}_{\mathrm{t}}=(1 / \mathrm{h}) \sum_{\mathrm{s}=0}^{\mathrm{h}-1} \Delta_{(1)} \mathrm{x}_{\mathrm{t}-\mathrm{s}}=(1 / \mathrm{h}) \sum_{\mathrm{s}=0}^{\mathrm{h}-1}\left(\mathrm{x}_{\mathrm{t}-\mathrm{s}}-\mathrm{x}_{\mathrm{t}-\mathrm{s}-1}\right), \quad$ the annualised change over a horizon of $h$ years is the average of the $h$ one-year changes. Writing

\footnotetext{
${ }^{6}$ For related analyses, see Flood and Taylor (1996), Isard (1995, p. 49), Lothian (1985) and Obstfeld (1995).
} 
$\mathrm{r}_{\mathrm{ct}}=\mathrm{p}_{\mathrm{ct}}-\mathrm{p}_{\mathrm{t}}^{*}$ for the Big Mac price in country $\mathrm{c}$ in terms of that in the US (as before), relative PPP implies that, for horizon $\mathrm{h}, \Delta_{(\mathrm{h})} \mathrm{s}_{\mathrm{ct}}=\Delta_{(\mathrm{h})} \mathrm{r}_{\mathrm{ct}}$, or dividing both sides by $\mathrm{h}$,

$$
\Delta^{(\mathrm{h})} \mathrm{S}_{\mathrm{ct}}=\Delta^{(\mathrm{h})} \mathrm{r}_{\mathrm{ct}} \text {. }
$$

Equation (4.1) states that exchange-rate changes are equal to the relative-price changes, with changes expressed as annual averages. To examine the content of this equation, we initially set $\mathrm{h}=$ 1 and plot one-year exchange rates changes against the corresponding price changes for all countries. The graph on the top left-hand corner of Figure 4.1 contains the results. As can be seen, there is considerable dispersion around the solid 45-degree line, with a root-mean-squared error (RMSE) of 14 percent. $^{7}$ In the other panels of the figure, as the horizon $\mathrm{h}$ increases, the points become noticeably closer to the 45-degree line and the RMSE falls continuously to end up at 2 percent for $\mathrm{h}=14$ years. To clarify matters, Figure 4.2 provides a blow up of the graphs for $\mathrm{h}=1$, 6 and 12.

To shed more light on the decrease in volatility as the horizon increases, consider the following parsimonious data-generating process for the real exchange rate

$$
\mathrm{q}_{\mathrm{t}}=\alpha+\beta \mathrm{q}_{\mathrm{t}-1}+\varepsilon_{\mathrm{t}}
$$

where $\alpha$ and $\beta$ are constants and the random disturbance term $\varepsilon_{t}$ is iid, independent of $\mathrm{q}_{\mathrm{t}-1}$, with a zero mean and variance $\sigma_{\varepsilon}^{2}$. Figure 3.3 showed that there is considerable persistence in the behaviour of q over time, which could be consistent with model (4.2) with a high value of $\beta$. The stationarity of the real rate implies $0<\beta<1$, and the variance of $q$ is $\sigma^{2}=\sigma_{\varepsilon}^{2} /\left(1-\beta^{2}\right)$. On the other hand, if follows a random walk, we have $\beta=1$, so that $\mathrm{q}_{\mathrm{t}}=\alpha+\mathrm{q}_{\mathrm{t}-1}+\varepsilon_{\mathrm{t}}=\left(\mathrm{t}-\mathrm{t}_{0}\right) \alpha+\mathrm{q}_{\mathrm{t}_{0}}+\sum_{\mathrm{s}=\mathrm{t}_{0}+1}^{\mathrm{t}} \varepsilon_{\mathrm{s}}$, where $\mathrm{q}_{\mathrm{t}_{0}}$ is the initial value. Hence, its variance at time $\mathrm{t}$ is $\sigma_{\mathrm{t}}^{2}=\left(\mathrm{t}-\mathrm{t}_{0}\right) \sigma_{\varepsilon}^{2}$ if the initial value is treated as fixed.

To examine the variance of the annualised change over horizon $h, \Delta^{(\mathrm{h})} \mathrm{q}_{\mathrm{t}}$, consider first the stationary case, in which $0<\beta<1$. Equation (4.2) implies $\mathrm{q}_{\mathrm{t}}-\mathrm{q}_{\mathrm{t}-\mathrm{h}}=\beta\left(\mathrm{q}_{\mathrm{t}-1}-\mathrm{q}_{\mathrm{t}-\mathrm{h}-1}\right)+\varepsilon_{\mathrm{t}}-\varepsilon_{\mathrm{t}-\mathrm{h}}$ $(\mathrm{h}>0)$, which can be written as $\Delta^{(\mathrm{h})} \mathrm{q}_{\mathrm{t}}=\beta \Delta^{(\mathrm{h})} \mathrm{q}_{\mathrm{t}-1}+\Delta^{(\mathrm{h})} \varepsilon_{\mathrm{t}}$, so that

$$
\operatorname{var}\left[\Delta^{(\mathrm{h})} \mathrm{q}_{\mathrm{t}}\right]=\beta^{2} \operatorname{var}\left[\Delta^{(\mathrm{h})} \mathrm{q}_{\mathrm{t}}\right]+\frac{2}{\mathrm{~h}^{2}} \sigma_{\varepsilon}^{2}-\frac{2 \beta}{\mathrm{h}} \operatorname{cov}\left[\Delta^{(\mathrm{h})} \mathrm{q}_{\mathrm{t}-1}, \varepsilon_{\mathrm{t}-\mathrm{h}}\right]
$$

The covariance term in the above is

\footnotetext{
${ }^{7}$ This RMSE is the square root of the ratio of $\sum_{\mathrm{c}} \sum_{\mathrm{t}}\left(\Delta_{(1)} \mathrm{r}_{\mathrm{ct}}-\Delta_{(1)} \mathrm{s}_{\mathrm{ct}}\right)^{2}$ to the number of observations, which measures the dispersion of real exchange rate changes over a one-year horizon.
} 


$$
\operatorname{cov}\left[\Delta^{(h)} \mathrm{q}_{\mathrm{t}-1}, \varepsilon_{\mathrm{t}-\mathrm{h}}\right]= \begin{cases}\operatorname{cov}\left[\mathrm{q}_{\mathrm{t}-1}-\mathrm{q}_{\mathrm{t}-2}, \varepsilon_{\mathrm{t}-1}\right]=\operatorname{cov}\left[\mathrm{q}_{\mathrm{t}-1}, \varepsilon_{\mathrm{t}-1}\right]=\sigma_{\varepsilon}^{2} & \text { if } \mathrm{h}=1 \\ \operatorname{cov}\left[\mathrm{q}_{\mathrm{t}-1}-\mathrm{q}_{\mathrm{t}-\mathrm{h}-1}, \varepsilon_{\mathrm{t}-\mathrm{h}}\right]=0 & \text { if } \mathrm{h}>1\end{cases}
$$

so that

$$
\operatorname{var}\left[\Delta^{(h)} q_{t}\right]= \begin{cases}\frac{2(1-\beta)}{1-\beta^{2}} \sigma_{\varepsilon}^{2}=\frac{2}{1+\beta} \sigma_{\varepsilon}^{2} & \text { if } h=1 \\ \frac{2}{h^{2}\left(1-\beta^{2}\right)} \sigma_{\varepsilon}^{2} & \text { if } h>1 .\end{cases}
$$

Therefore, we can see that $\operatorname{var}\left[\Delta^{(h)} q_{t}\right]$ decreases when the horizon $h$ increases for the stationary case. This is represented in Panel A of Figure 4.3 by the reciprocal quadratic curve of the form $\operatorname{var}\left[\Delta^{(\mathrm{h})} \mathrm{q}_{\mathrm{t}}\right] \propto 1 / \mathrm{h}^{2}$, with $\beta=0.6$.

If $\beta=1$, equation (4.2) implies that $\mathrm{q}_{\mathrm{t}}-\mathrm{q}_{\mathrm{t}-\mathrm{h}}=\mathrm{h} \alpha+\sum_{\mathrm{s}=\mathrm{t}-\mathrm{h}+1}^{\mathrm{t}} \varepsilon_{\mathrm{s}}$. When divided by $\mathrm{h}$, we have $\Delta^{(\mathrm{h})} \mathrm{q}_{\mathrm{t}}=\alpha+\frac{1}{\mathrm{~h}} \sum_{\mathrm{s}=\mathrm{t}-\mathrm{h}+1}^{\mathrm{t}} \varepsilon_{\mathrm{s}}$, so that

$$
\operatorname{var}\left[\Delta^{(\mathrm{h})} \mathrm{q}_{\mathrm{t}}\right]=\frac{1}{\mathrm{~h}^{2}} \operatorname{var}\left[\sum_{\mathrm{s}=\mathrm{t}-\mathrm{h}+1}^{\mathrm{t}} \varepsilon_{\mathrm{s}}\right]=\frac{\sigma_{\varepsilon}^{2}}{\mathrm{~h}}
$$

which is represented in Panel A of Figure 4.3 by the reciprocal curve of the form $\operatorname{var}\left[\Delta^{(h)} q_{t}\right] \propto 1 / h$. We can see that here $\operatorname{var}\left[\Delta^{(h)} q_{t}\right]$ also declines, but at rate $h$, which is slower than in the stationary case. This contrast is more apparent by considering total volatility, defined as $\operatorname{var}\left[\Delta_{(\mathrm{h})} \mathrm{q}_{\mathrm{t}}\right]=\mathrm{h}^{2} \operatorname{var}\left[\Delta^{(\mathrm{h})} \mathrm{q}_{\mathrm{t}}\right]$. From equations (4.3) for $\mathrm{h}>1$ and (4.4), we have

$$
\operatorname{var}\left[\Delta_{(\mathrm{h})} \mathrm{q}_{\mathrm{t}}\right]=\left\{\begin{array}{cc}
\frac{2}{1-\beta^{2}} \sigma_{\varepsilon}^{2} & \beta<1 \\
\mathrm{~h} \sigma_{\varepsilon}^{2} & \beta=1,
\end{array}\right.
$$

which is constant when $\beta<1$ and increases linearly when $\beta=1$, as indicated in Panel $\mathrm{B}$ of Figure 4.3 .

Equation (4.5) is a key result that shows that when the real rate is stationary, the total volatility is constant as the length of the horizon expands, while it increases in the non-stationary case. Although this is based on the simple AR(1) model, the implications carry over to more general cases. For a given horizon h, the RMSE of Figure 4.1 is the standard deviation of the annualised changes, or an estimate of $\sqrt{\operatorname{var}\left[\Delta^{(h)} q_{t}\right]}$. Thus $h \times$ RMSE is the standard deviation of the total changes, $\sqrt{\operatorname{var}\left[\Delta_{(\mathrm{h})} \mathrm{q}_{\mathrm{t}}\right]}$, which under stationarity will also be constant with respect to $\mathrm{h}$. We use the RMSEs from Figure 4.1 in Figure 4.4 to plot $h \times$ RMSE against the horizon. As can be seen, total 
volatility first increases and after about 4 years fluctuates within a band that is less than 10 percentage points wide. It seems not unreasonable to interpret this evidence as saying real rates are stationary, that is, relative purchasing parity holds at longer horizons.

The above analysis shows that as the PPP adjustment mechanism is not evident until after a longish period, the speed of adjustment of exchange rates to prices is not rapid, which presumably reflects transaction costs, informational costs, sticky prices due to contracts and menu costs, etc. But over the medium-term of more than three years, the tendency for exchange rates to reflect PPP is clear. In the context of the discussion of Section 2, it seems that stochastic PPP with a relatively high value of the variance $\sigma^{2}$ is the way to think of the relationship between exchange rates and prices in the short term. ${ }^{8}$

8 Conventional tests of the stationarity of real exchange rates are usually based on the equation $\Delta \mathrm{q}_{\mathrm{t}}=\alpha+\rho \mathrm{q}_{\mathrm{t}-1}+\Sigma_{\mathrm{k}} \lambda_{\mathrm{k}} \Delta \mathrm{q}_{\mathrm{t}-\mathrm{k}}+\varepsilon_{\mathrm{t}}$. The null hypothesis of a unit root is $\rho=0$, while the alternative of stationarity corresponds to $-1<\rho<0$. To implement this approach with the Big Mac data, due to the limited sample size ( $\mathrm{T}=15$, before lags), a parsimonious specification that omits $\Delta \mathrm{q}_{\mathrm{t}-\mathrm{k}}$ on the right-hand side has to be employed. Following Lan (2006), we can gain efficiency by exploiting the multicurrency $(\mathrm{N}=24)$ nature of the data and take a panel/SUR approach to estimate the model $\Delta \mathrm{q}_{\mathrm{ct}}=\alpha_{\mathrm{c}}+\rho \mathrm{q}_{\mathrm{c}, \mathrm{t}-1}+\varepsilon_{\mathrm{ct}}$, for $\mathrm{c}=1, \ldots, \mathrm{N}$ currencies and $\mathrm{t}=2, \ldots, \mathrm{T}$ years, where the parameter $\rho$ takes a common value to conserve degrees of freedom.

To allow for common shocks, the disturbances $\varepsilon_{\mathrm{ct}}$ are correlated across currencies with $\mathrm{N} \times \mathrm{N}$ covariance matrix $\mathrm{E}\left(\boldsymbol{\varepsilon}_{\mathrm{t}} \boldsymbol{\varepsilon}_{\mathrm{t}}^{\prime}\right)=\boldsymbol{\Sigma}$, where $\boldsymbol{\varepsilon}_{\mathrm{t}}=\left[\varepsilon_{\mathrm{ct}}\right]$. However, as the number of currencies exceeds the sample size $(\mathrm{N}>\mathrm{T})$, there is an undersized sample problem and the conventional estimate of $\Sigma$ is singular. To deal with the problem, Lan (2006) patterns $\Sigma$ in two ways. (i) A type of block-independence whereby countries are classified into three blocks: Asia Pacific, Europe and other. As it is assumed that exchange rate innovations between countries in different blocks are uncorrelated, this is called "block-sectional independence". (ii) A process which summarises the cross-country dependence in one factor common to all countries. The common factor approach uses as weights the shares in world trade and world GDP. Using Lan's (2006) iterative methodology, which involves bias-adjustments, the results are:

\begin{tabular}{|c|c|c|c|}
\hline & \multicolumn{3}{|c|}{ Covariance matrix specified as } \\
\hline & \multirow{2}{*}{$\begin{array}{c}\text { Block-sectional } \\
\text { independence }\end{array}$} & \multicolumn{2}{|c|}{ Common factor model } \\
\hline & & Trade & GDP \\
\hline Estimated $\rho$ & -0.18 & -0.11 & -0.09 \\
\hline Half-life (years), $-\log 2 / \log (1+\rho)$ & 3.5 & 5.9 & 7.3 \\
\hline Test statistic for $H_{0}: \rho=0$ & -4.15 & -4.84 & -4.16 \\
\hline $\begin{array}{r}\text { Critical value } 1 \% \\
5 \% \\
10 \%\end{array}$ & $\begin{array}{l}-6.50 \\
-4.17 \\
-3.35\end{array}$ & $\begin{array}{l}-4.84 \\
-3.72 \\
-3.33\end{array}$ & $\begin{array}{l}-5.19 \\
-4.22 \\
-3.37\end{array}$ \\
\hline
\end{tabular}

Thus, the unit root hypothesis is rejected at about the 5 percent level for all three cases. The estimated half-lives indicate relatively slow adjustment, which is consistent with the other results of this section. We also test the assumption of a common $\rho$ for all countries using a quasi F-test (Lan, 2006). The test statistic is 2.35 under block-sectional independence $(5 \%$ critical value $=6.35), 0.24$ under the trade-based common factor model $(0.40)$ and 0.27 with the GDP-based common factor model (0.48), so we are unable to reject the hypothesis. 


\section{Does the BMI Predict Future Currency Movements?}

In this section, we examine the predictive power of the Big Mac Index by asking the question, can a currency be expected to appreciate (depreciate) in the future if it is currently undervalued (overvalued)? And if it does mean revert in this manner, how long does it take? For an early analysis along these lines, see Cumby (1996).

As our objective is to examine the information contained in the current BMI regarding future currency values, we start by defining the horizon for future changes in the real rate as

$$
\Delta_{(h)} q_{t+h}=q_{t+h}-q_{t},
$$

which is the future change in $\mathrm{q}$ from the year $\mathrm{t}$ to $\mathrm{t}+\mathrm{h}$. This total change in $\mathrm{q}$ over $\mathrm{h}$ years is just the sum of the corresponding $h$ annual changes, $\Delta_{(h)} q_{t+h}=\sum_{s=0}^{h-1} \Delta_{(1)} q_{t+h-s}=\sum_{s=0}^{h-1}\left(q_{t+h-s}-q_{t+h-s-1}\right)$. Regarding current mispricing, the use of $\mathrm{q}_{\mathrm{t}}$ would not be satisfactory due to the bias identified above in Section 3. Instead we use

$$
\mathrm{d}_{\mathrm{t}}=\mathrm{q}_{\mathrm{t}}-\overline{\mathrm{q}},
$$

with $\overline{\mathrm{q}}$ the sample mean, which can be interpreted as the equilibrium exchange rate. Thus, now the currency is over (under) -valued if $d_{t}>0(<0)$. Under PPP, deviations from parity die out, so that if $d_{t}>0(<0)$, the future value $q_{t+h}$ decreases (increases) relative to the current value $q_{t}$. To examine whether this is the case, we plot in Figure 5.1 the subsequent changes $\Delta_{(\mathrm{h})} \mathrm{q}_{\mathrm{t}+\mathrm{h}}$ against $\mathrm{d}_{\mathrm{t}}$ using the 24-country Big Mac data for horizons of $h=1, \ldots, 14$ years. PPP predicts that the points should lie in the second and fourth quadrants of the graphs, and Figure 5.1 shows this is indeed mostly the case, with the pattern becoming more pronounced as the horizon increases. To examine the statistical significance of this pattern, we first carry out a $\chi^{2}$-test of the independence of $\Delta_{(\mathrm{h})} \mathrm{q}_{\mathrm{t}+\mathrm{h}}$ and $\mathrm{d}_{\mathrm{t}} \cdot{ }^{9}$ The test statistic is contained in the top box of each graph in Figure 5.1, and is significant for all horizons except 14 years (for which there are few observations), so we can reject independence. Figure 5.2 plots the test statistic against the horizon $\mathrm{h}$ and it can be seen that a maximum is reached for a horizon of $h=5$ or 6 , so that in this sense the current deviation best predicts subsequent changes over a five- or six-year horizon.

In each panel of Figure 5.1 we also report the least-squares estimates of the predictive regression

$$
\Delta_{(\mathrm{h})} \mathrm{q}_{\mathrm{t}+\mathrm{h}}=\eta^{\mathrm{h}}+\phi^{\mathrm{h}} \mathrm{d}_{\mathrm{t}}+\mathrm{u}_{\mathrm{t}}^{\mathrm{h}}
$$

\footnotetext{
${ }^{9}$ This test is based on a $2 \times 2$ contingency table with rows for the sign of $d_{t}$ and columns for the sign of $\Delta_{(h)} q_{t+h}$.
} 
where, for horizon $h, \eta^{h}$ is the intercept, $\phi^{h}$ the slope and $u_{t}^{h}$ a zero-mean disturbance term. Panel A of Table 5.1 reproduces the estimates of this regression in the first line for each horizon, while column 6 reproduces the $\chi^{2}$ values discussed in the previous paragraph; the information in column 7 will be discussed subsequently. To examine the effect of inclusion of an intercept, we report for each horizon the slope coefficient when the intercept is suppressed, and the results are qualitatively similar. Panel B of Table 5.1 redoes the analysis with non-overlapping observations only, and in all four sets of results

- overlapping and non-overlapping, with and without an intercept - the slope coefficient is significantly negative, indicating that the adjustment goes in the expected direction.

To further interpret equation (5.3), we combine equations (5.1), (5.2) and (5.3) to obtain

$$
\mathrm{q}_{\mathrm{t}+\mathrm{h}}=\left(\eta^{\mathrm{h}}-\phi^{\mathrm{h}} \overline{\mathrm{q}}\right)+\left(\phi^{\mathrm{h}}+1\right) \mathrm{q}_{\mathrm{t}}+\mathrm{u}_{\mathrm{t}}^{\mathrm{h}} .
$$

Under PPP, $\mathrm{q}_{\mathrm{t}+\mathrm{h}}$ converges to the equilibrium value $\overline{\mathrm{q}}$, so that

$$
\eta^{\mathrm{h}}=0, \quad \phi^{\mathrm{h}}=-1 .
$$

A test of restriction (5.5) reveals whether or not there is full adjustment to mispricing over horizon h. The F-statistics for (5.5) are presented in column 7 and 13 of Table 5.1 for the overlapping and non-overlapping cases. For the purposes of testing, the results for the non-overlapping case are more reliable and as can be seen from Panel B, the F-statistic is minimised for a three-year horizon and is not significant. The F-statistic is also not significant for a six-year horizon, but is significant for all other horizons. These results point to the conclusion that roughly speaking, over a period of three to six years there is more or less full adjustment of the rate to mispricing.

Panel A of Figure 5.3 plots the estimated intercepts and slopes, $\eta^{\mathrm{h}}$ and $\phi^{\mathrm{h}}$, against the horizon when overlapping observations are omitted. Three comments can be made. First, the intercepts are negative for all horizons up to 10, but many of the 95-percent confidence intervals include zero. Second, the slope generally decreases with $\mathrm{h}$ and the 95-percent confidence interval includes -1 for horizons 3 to 6 years as well as 9 years. As the absolute value of $\phi^{\mathrm{h}}$ is the fraction of the total adjustment that occurs over horizon $\mathrm{h}$, it is reasonable for a larger share of the adjustment to be completed over a longer horizon. Third, we should possibly pay more attention to the estimated slope, rather than the intercept. If, for some reason, the equilibrium rate differs from the mean $\bar{q}$, then the difference would be absorbed into the intercept, which becomes non-zero even if PPP holds. 
Next, consider as an illustrative example the AR(1) case, equation (4.2), $q_{t}=\alpha+\beta q_{t-1}+\varepsilon_{t}$, so that

$$
\mathrm{q}_{\mathrm{t}+\mathrm{h}}=\frac{\alpha\left(1-\beta^{\mathrm{h}-1}\right)}{1-\beta}+\beta^{\mathrm{h}} \mathrm{q}_{\mathrm{t}}+\sum_{\mathrm{j}=1}^{\mathrm{h}} \beta^{\mathrm{h}-\mathrm{j}} \varepsilon_{\mathrm{t}+\mathrm{j}}
$$

Equating the intercepts and slopes of the right-hand-sides of equations (5.4) and (5.6), we have $\left(\eta^{\mathrm{h}}-\phi^{\mathrm{h}} \overline{\mathrm{q}}\right)=\alpha\left(1-\beta^{\mathrm{h}-1}\right) /(1-\beta),\left(\phi^{\mathrm{h}}+1\right)=\beta^{\mathrm{h}}$, or

$$
\eta^{\mathrm{h}}=\overline{\mathrm{q}} \beta^{\mathrm{h}}\left(1-\frac{1}{\beta}\right), \quad \phi^{\mathrm{h}}=\beta^{\mathrm{h}}-1 .
$$

We use $\bar{q}=-0.2$, the grand average from the Big Mac data, and $\beta=0.6$, as before, in equation (5.7) to plot the intercept $\eta^{\mathrm{h}}$ and slope $\phi^{\mathrm{h}}$ against $\mathrm{h}$, and Panel B of Figure 5.3 gives the results. As these plots do not match those of Panel A too well, it seems that the actual data generating process is somewhat more complex than the simple AR(1) model.

Since the work of Meese and Rogoff $(1983 a, b)$, the random walk model has become the gold standard by which to judge the forecast performance of exchange-rate models. Accordingly, we compare the forecasts from the Big Mac Index and the bias-adjusted BMI with those from a random walk. Under the BMI, absolute parity holds and the forecast real exchange rate at any horizon $\mathrm{h}$ is zero, $\mathrm{q}_{\mathrm{t}+\mathrm{h}}=0$; the bias-adjusted BMI, as represented by equations (5.3) and (5.5), implies $\mathrm{q}_{\mathrm{t}+\mathrm{h}}=\overline{\mathrm{q}}$; and the random walk predicts no change, $\mathrm{q}_{\mathrm{t}+\mathrm{h}}=\mathrm{q}_{\mathrm{t}}$. We compute the root-mean-squared error of the forecasts over all currencies and years for horizons $h=1, \ldots, 14$, and Figure 5.4 shows that the random walk model outperforms the BMI for all horizons, which is the familiar Meese-Rogoff result. ${ }^{10}$ However the figure also reveals that beyond a one-year horizon the bias-adjusted BMI

${ }^{10}$ Note that in addition to the RMSEs of Figure 5.4, earlier we presented another set in Figure 4.1. These are related as follows. For simplicity, suppose there are $\mathrm{T}$ realisations of one exchange rate, which we forecast for all horizons by sample mean $\overline{\mathrm{q}}$. Denote the RMSE for horizon h by

$$
\operatorname{RMSE}_{1}^{\mathrm{h}}=\sqrt{(1 / \mathrm{T}) \sum_{\mathrm{t}=1}^{\mathrm{T}}\left(\mathrm{q}_{\mathrm{t}+\mathrm{h}}-\overline{\mathrm{q}}\right)^{2}},
$$

which is a simplified expression for the RMSEs presented in Figure 5.4 associated with the bias-adjusted BMI. The corresponding simplified expression for the RMSEs of Figure 4.1 is

$$
\operatorname{RMSE}_{2}^{\mathrm{h}}=(1 / \mathrm{h}) \sqrt{(1 / \mathrm{T}) \sum_{\mathrm{t}=1}^{\mathrm{T}}\left(\mathrm{q}_{\mathrm{t}+\mathrm{h}}-\mathrm{q}_{\mathrm{t}}\right)^{2}} .
$$

If $\mathrm{q}_{\mathrm{t}}$ does not deviate too much from $\overline{\mathrm{q}}, \operatorname{RMSE}_{2}^{\mathrm{h}} \approx(1 / \mathrm{h}) \mathrm{RMSE}_{1}^{\mathrm{h}}$. While this is only an approximation, this relationship is likely to be the main reason that the RMSEs of Figure 4.1 decrease substantially with the horizon h, while those of Figure 5.4 do not exhibit this pattern.

In the AR(1) case, $\mathrm{q}_{\mathrm{t}}=\alpha+\beta \mathrm{q}_{\mathrm{t}-1}+\varepsilon_{\mathrm{t}}=\overline{\mathrm{q}}+\sum_{\mathrm{j}=0}^{\infty} \beta^{\mathrm{j}} \varepsilon_{\mathrm{t}-\mathrm{j}}$, and the simplified expression for the first version of the of the square of the RMSE is

$$
\left(\operatorname{RMSE}_{1}^{\mathrm{h}} \mid \operatorname{AR}(1)\right)^{2}=(1 / \mathrm{T}) \sum_{\mathrm{t}=1}^{\mathrm{T}}\left(\sum_{\mathrm{j}=0}^{\infty} \beta^{\mathrm{j}} \varepsilon_{\mathrm{t}+\mathrm{h}-\mathrm{j}}\right)^{2} \text {, with } \mathrm{E}\left[\left(\operatorname{RMSE}_{1}^{\mathrm{h}} \mid \operatorname{AR}(1)\right)^{2}\right]=\frac{\sigma_{\varepsilon}^{2}}{1-\beta^{2}} .
$$


beats the random walk. For example, for a 4-year horizon, the RMSE is about 40 percent for the BMI, 30 percent for the random walk and something less than 20 percent for the bias-adjusted BMI. This is an encouraging result for the bias-adjusted BMI.

This section can be summarised as follows:

- The direction of future changes in currency values is clearly not independent of current deviations from parity: Overvalued currencies subsequently depreciate, while undervalued ones appreciate.

- The adjustment to deviations from parity tends to be more or less fully complete over a period of three to six years.

- The bias-adjusted Big Mac Index beats the random walk model for all but one-year horizons, demonstrating that it has considerable predictive power regarding future currency values.

\section{The Split Between the Nominal Rate and Prices}

In this section, we examine the relationship between mispricing and the two components of the real exchange rate -- the nominal exchange rate and inflation -- over different horizons in the future.

From the definition of the real exchange rate, $\mathrm{q}_{\mathrm{t}}=\log \left(\mathrm{P}_{\mathrm{t}} / \mathrm{S}_{\mathrm{t}} \mathrm{P}_{\mathrm{t}}^{*}\right)$, and using the previous change notation of $\Delta_{(\mathrm{h})} \mathrm{X}_{\mathrm{t}+\mathrm{h}}=\log \left(\mathrm{X}_{\mathrm{t}+\mathrm{h}} / \mathrm{X}_{\mathrm{t}}\right)$ we have the identity

$$
\Delta_{(\mathrm{h})} \mathrm{q}_{\mathrm{t}+\mathrm{h}}=-\Delta_{(\mathrm{h})} \mathrm{s}_{\mathrm{t}+\mathrm{h}}+\Delta_{(\mathrm{h})} \mathrm{r}_{\mathrm{t}+\mathrm{h}}
$$

where, e. g., $\Delta_{(\mathrm{h})} \mathrm{r}_{\mathrm{t}+\mathrm{h}}=\Delta_{(\mathrm{h})} \mathrm{p}_{\mathrm{t}+\mathrm{h}}-\Delta_{(\mathrm{h})} \mathrm{p}_{\mathrm{t}+\mathrm{h}}^{*}$ is the cumulative inflation differential over $\mathrm{h}$ years in the future. Equation (6.1) decomposes the future change in the real rate into the corresponding changes in the nominal rate and the inflation differential. A positive value of $\Delta_{(\mathrm{h})} \mathrm{q}_{\mathrm{t}+\mathrm{h}}$ means that the inflation differential exceeds the nominal depreciation of the exchange rate, which amounts to a real appreciation over an h-year horizon.

To examine the mean-reverting behaviour of the two components over different horizons, consider predictive regressions analogous to equation (5.3):

The corresponding second version is

$$
\left(\operatorname{RMSE}_{2}^{\mathrm{h}} \mid \operatorname{AR}(1)\right)^{2}=\left(1 / \mathrm{h}^{2}\right)(1 / \mathrm{T}) \sum_{\mathrm{t}=1}^{\mathrm{T}}\left[\sum_{\mathrm{j}=0}^{\infty} \beta^{\mathrm{j}}\left(\varepsilon_{\mathrm{t}+\mathrm{h}-\mathrm{j}}-\varepsilon_{\mathrm{t}-\mathrm{j}}\right)\right]^{2} \text {, with } \mathrm{E}\left[\left(\operatorname{RMSE}_{2}^{\mathrm{h}} \mid \operatorname{AR}(1)\right)^{2}\right]=\frac{2\left(1-2 \beta^{\mathrm{h}}\right)}{\mathrm{h}^{2}} \frac{\sigma_{\varepsilon}^{2}}{1-\beta^{2}} .
$$

As $\mathrm{E}\left[\left(\operatorname{RMSE}_{2}^{\mathrm{h}} \mid \mathrm{AR}(1)\right)^{2}\right]=\left[2\left(1-2 \beta^{\mathrm{h}}\right) / \mathrm{h}^{2}\right] \cdot \mathrm{E}\left[\left(\operatorname{RMSE}_{1}^{\mathrm{h}} \mid \mathrm{AR}(1)\right)^{2}\right]$, there is a similar relationship between the two measures whereby the first is independent of the horizon, while the second declines with $\mathrm{h}$. 


$$
-\Delta_{(\mathrm{h})} \mathrm{s}_{\mathrm{t}+\mathrm{h}}=\eta_{\mathrm{s}}^{\mathrm{h}}+\phi_{\mathrm{s}}^{\mathrm{h}} \mathrm{d}_{\mathrm{t}}+\mathrm{u}_{\mathrm{st}}^{\mathrm{h}}, \quad \Delta_{(\mathrm{h})} \mathrm{r}_{\mathrm{t}+\mathrm{h}}=\eta_{\mathrm{r}}^{\mathrm{h}}+\phi_{\mathrm{r}}^{\mathrm{h}} \mathrm{d}_{\mathrm{t}}+\mathrm{u}_{\mathrm{rt}}^{\mathrm{h}},
$$

where, for horizon $\mathrm{h}, \eta_{\mathrm{s}}^{\mathrm{h}}, \phi_{\mathrm{s}}^{\mathrm{h}}, \eta_{\mathrm{r}}^{\mathrm{h}}$ and $\phi_{\mathrm{r}}^{\mathrm{h}}$ are parameters, $\mathrm{d}_{\mathrm{t}}$ is current mispricing defined by equation (5.2), and $\mathrm{u}_{\mathrm{st}}^{\mathrm{h}}$ and $\mathrm{u}_{\mathrm{rt}}^{\mathrm{h}}$ are zero-mean error terms. ${ }^{11}$ The parameters in equations (5.3) and (6.2) satisfy

$$
\eta_{\mathrm{s}}^{\mathrm{h}}+\eta_{\mathrm{r}}^{\mathrm{h}}=\eta^{\mathrm{h}}, \quad \phi_{\mathrm{s}}^{\mathrm{h}}+\phi_{\mathrm{r}}^{\mathrm{h}}=\phi^{\mathrm{h}},
$$

while the errors satisfy $u_{s t}^{h}+u_{r t}^{h}=u_{t}^{h}$. To interpret model (6.2), for simplicity we set the two intercepts $\eta_{\mathrm{s}}^{\mathrm{h}}=\eta_{\mathrm{r}}^{\mathrm{h}}=0$ and the error terms to their expected value of zero, so that $-\Delta_{(\mathrm{h})} \mathrm{s}_{\mathrm{t}+\mathrm{h}}=\phi_{\mathrm{s}}^{\mathrm{h}} \mathrm{d}_{\mathrm{t}}, \quad \Delta_{(\mathrm{h})} \mathrm{r}_{\mathrm{t}+\mathrm{h}}=\phi_{\mathrm{r}}^{\mathrm{h}} \mathrm{d}_{\mathrm{t}}$. Adding both sides of these two equations then gives $\Delta_{(\mathrm{h})} \mathrm{q}_{\mathrm{t}+\mathrm{h}}=\left(\phi_{\mathrm{s}}^{\mathrm{h}}+\phi_{\mathrm{r}}^{\mathrm{h}}\right) \mathrm{d}_{\mathrm{t}}$, or $\mathrm{d}_{\mathrm{t}}=\Delta_{(\mathrm{h})} \mathrm{q}_{\mathrm{t}+\mathrm{h}} /\left(\phi_{\mathrm{s}}^{\mathrm{h}}+\phi_{\mathrm{r}}^{\mathrm{h}}\right)$. Substituting back this expression for d gives

$$
-\Delta_{(\mathrm{h})} \mathrm{s}_{\mathrm{t}+\mathrm{h}}=\lambda^{\mathrm{h}} \Delta_{(\mathrm{h})} \mathrm{q}_{\mathrm{t+h}}, \quad \Delta_{(\mathrm{h})} \mathrm{r}_{\mathrm{t}+\mathrm{h}}=\left(1-\lambda^{\mathrm{h}}\right) \Delta_{(\mathrm{h})} \mathrm{q}_{\mathrm{t}+\mathrm{h}},
$$

where $\lambda^{\mathrm{h}}=\phi_{\mathrm{s}}^{\mathrm{h}} /\left(\phi_{\mathrm{s}}^{\mathrm{h}}+\phi_{\mathrm{r}}^{\mathrm{h}}\right)$. As $\left(\phi_{\mathrm{s}}^{\mathrm{h}}+\phi_{\mathrm{r}}^{\mathrm{h}}\right)$ is the response of $\mathrm{q}$ to mispricing $\mathrm{d}, \lambda^{\mathrm{h}}$ is the share of this response that is brought about via the nominal rate, while $\left(1-\lambda^{\mathrm{h}}\right)$ is the share for prices.

The least-squares estimator automatically satisfies the aggregation constraints (6.3), and Table 6.1 presents the results using the 24-country Big Mac data for horizons $h=1, \ldots, 14$. As most of the parameters are insignificant, the split between the nominal rate and inflation cannot be precisely estimated. The $\chi^{2}$-values in this table test the independence between (i) $-\Delta_{(k)} s_{t+h}$ and $d_{t}$, and (ii) $\Delta_{(\mathrm{b})} \mathrm{r}_{\mathrm{t}+\mathrm{h}}$ and $\mathrm{d}_{\mathrm{t}}$. As for most horizons the $\chi^{2}$-values for the nominal rate are considerably higher than those for inflation, we can possibly conclude that future changes in the real rate are mainly bought about by nominal exchange rates, but recognise the uncertainty in the split. Looking at Panel B of the table, which refers to the non-overlapping case, it can be seen that the $\chi^{2}$-value for the nominal rate is maximised for a horizon of 4-7 years, which is not too different to the pattern for the real rate (Table 5.1).

${ }^{11}$ Model (6.2) can also be viewed as being part of the reduced form of a system of simultaneous equations. The structural equations comprise (5.3) and (using an obvious notation)

$$
-\Delta_{(\mathrm{h})} \mathrm{s}_{\mathrm{t}+\mathrm{h}}=\alpha_{\mathrm{s}}^{\mathrm{h}}+\beta_{\mathrm{s}}^{\mathrm{h}} \Delta_{(\mathrm{h})} \mathrm{q}_{\mathrm{t}+\mathrm{h}}+\varepsilon_{\mathrm{st}}^{\mathrm{h}}, \quad \Delta_{(\mathrm{h})} \mathrm{r}_{\mathrm{t}+\mathrm{h}}=\alpha_{\mathrm{r}}^{\mathrm{h}}+\beta_{\mathrm{r}}^{\mathrm{h}} \Delta_{(\mathrm{h})} \mathrm{q}_{\mathrm{t}+\mathrm{h}}+\varepsilon_{\mathrm{rt}}^{\mathrm{h}},
$$

where the endogenous variables are $-\Delta_{(h)} \mathrm{s}_{\mathrm{t}+\mathrm{h}}, \Delta_{(\mathrm{h})} \mathrm{q}_{\mathrm{t+h}}$ and $\Delta_{(\mathrm{h})} \mathrm{r}_{\mathrm{t}+\mathrm{h}}$, while $\mathrm{d}_{\mathrm{t}}$ is exogenous. Substituting the right-hand side of equation (5.3) for $\Delta_{(h)} q_{t+h}$ in (6.2') then yields the reduced form, model (6.2) with

$$
\eta_{\mathrm{x}}^{\mathrm{h}}=\alpha_{\mathrm{x}}^{\mathrm{h}}+\phi_{\mathrm{x}}^{\mathrm{h}} \eta^{\mathrm{h}}, \quad \phi_{\mathrm{x}}^{\mathrm{h}}=\beta_{\mathrm{x}}^{\mathrm{h}} \phi^{\mathrm{h}}, \quad \mathrm{u}_{\mathrm{xt}}^{\mathrm{h}}=\varepsilon_{\mathrm{xt}}^{\mathrm{h}}+\beta_{\mathrm{x}}^{\mathrm{h}} \mathrm{u}_{\mathrm{t}}^{\mathrm{h}} \quad \mathrm{x}=\mathrm{s}, \mathrm{r} .
$$


There are four countries that experienced considerable monetary turmoil associated with currency redenominations or a sudden switch from a fixed to floating regime. These are Argentina, Brazil, Poland and Russia. When analysing nominal magnitudes like exchange rates and prices, it is possible that this type of disruption could substantially affect the results. When model (6.2) is reestimated with these countries omitted, two major changes occur. First, the tendency for changes in the real exchange rate to be brought about by variations in the nominal rate is substantially more pronounced. Second, the estimates are now much more precisely estimated. For details, see Appendix A3. The possible explanation for these changes is that most, if not all, of the changes in the exchange rates and prices that accompany monetary turmoil is unexpected. As these changes are only weakly related to past currency mispricing, including the experience of these four countries with the others skews the results and blurs the role of the nominal rate in doing most of the "heavy lifting" in the adjustment process.

Next, suppose that at some horizon $\mathrm{H}$ there is complete adjustment of the real rate to mispricing, so that

$$
\Delta_{(\mathrm{H})} \mathrm{q}_{\mathrm{t}+\mathrm{H}}=-\mathrm{d}_{\mathrm{t}} .
$$

According to this equation, if, for example, the currency is today undervalued by 10 percent $\left(d_{t}=-0.10\right)$, then over the next $H$ years it appreciates by the same amount, $q_{t+H}-q_{t}=0.10$. The complete adjustment restriction (5.5) then takes the form $\eta^{\mathrm{H}}=0, \phi^{\mathrm{H}}=-1$, so that (6.3) becomes

$$
\eta_{\mathrm{s}}^{\mathrm{H}}+\eta_{\mathrm{r}}^{\mathrm{H}}=0, \quad \phi_{\mathrm{s}}^{\mathrm{H}}+\phi_{\mathrm{r}}^{\mathrm{H}}=-1 .
$$

The hypothesis of complete adjustment restricts the equations for the nominal rate and inflation according to $\left(6.3^{\prime}\right)$. We use the seemingly unrelated estimator (SURE) to estimate the two equations in (6.2) as a system with the cross-equation restriction (6.3') imposed, and interpret the full adjustment horizon $H$ as being successively equal to $1, \ldots, 14$ years. Table 6.2 contains the results. While many of the estimates are again imprecisely determined, for the non-overlapping case, most of the estimates of $\phi_{\mathrm{s}}^{\mathrm{H}}$ for 2-4 year horizons are less than one standard error away from 1, which points to the nominal rate doing the bulk of the adjusting. But as the standard errors are still high, we conclude that the precise measurement of the nominal/inflation split remains elusive. However, when the four high-inflation countries are omitted from the analysis, the results become more informative with the nominal rate more clearly playing the role of the dominant adjuster to mispricing; see Appendix A3 for details. 


\section{The Geometry of Adjustment}

In this section, we consider further the adjustment process by developing a simple geometric framework that highlights the relative flexibility of the exchange rate and prices.

Consider model (6.2) for the complete-adjustment horizon H. Restriction (6.3') means that model (6.2) then becomes

$$
-\Delta_{(\mathrm{H})} \mathrm{s}_{\mathrm{t}+\mathrm{H}}=\phi_{\mathrm{s}}^{\mathrm{H}} \mathrm{d}_{\mathrm{t}}, \quad \Delta_{(\mathrm{H})} \mathrm{r}_{\mathrm{t}+\mathrm{H}}=-\left(1+\phi_{\mathrm{s}}^{\mathrm{H}}\right) \mathrm{d}_{\mathrm{t}},
$$

where for simplicity we have suppressed the intercepts and set the disturbances at their expected values of zero. The above equations can be written as

$$
\Delta_{(\mathrm{H})} \mathrm{s}_{\mathrm{t}+\mathrm{H}}=\gamma \mathrm{d}_{\mathrm{t}}, \quad \Delta_{(\mathrm{H})} \mathrm{r}_{\mathrm{t}+\mathrm{H}}=-(1-\gamma) \mathrm{d}_{\mathrm{t}},
$$

where $\gamma=-\phi_{s}^{H}$. If the currency is undervalued $\left(d_{t}<0\right)$, then prices at home are too low relative to those abroad, that is, $p_{t}<s_{t}+p_{t}^{*}+\bar{q}$. Thus, we expect $d_{t}<0$ to be associated with (i) a future nominal appreciation, $\Delta_{(\mathrm{H})} \mathrm{s}_{\mathrm{t}+\mathrm{H}} \leq 0$, implying that $\gamma \geq 0$, and/or (ii) a rise in relative inflation, $\Delta_{(\mathrm{H})} \mathrm{r}_{\mathrm{t}+\mathrm{H}} \geq 0$, implying $-(1-\gamma) \leq 0$. Accordingly, $0 \leq \gamma \leq 1$, which means that the nominal rate changes by a fraction $\gamma$ of the mispricing, while relative inflation changes by the remainder $1-\gamma$. When the nominal rate does most of the adjusting, the parameter $\gamma>0.5$, and we have the ranking of changes

$$
\left|\Delta_{(\mathrm{H})} \mathrm{r}_{\mathrm{t}+\mathrm{H}}\right|<\left|\Delta_{(\mathrm{H})} \mathrm{s}_{\mathrm{t}+\mathrm{H}}\right|<\left|\mathrm{d}_{\mathrm{t}}\right| .
$$

In words, the change in the rate is bracketed by the change in relative inflation and the initial mispricing.

Combining the two equations in (7.1) to eliminate $d_{t}$ yields

$$
\Delta_{(\mathrm{H})} \mathrm{s}_{\mathrm{t}+\mathrm{H}}=-\left(\frac{\gamma}{1-\gamma}\right) \Delta_{(\mathrm{H})} \mathrm{r}_{\mathrm{t}+\mathrm{H}} .
$$

As the parameter $\gamma$ is a positive fraction, the ratio $-\gamma /(1-\gamma)$ on the right-hand side of the above falls in the range $[-\infty, 0]$. Equation (7.2) describes the simultaneous adjustment of the exchange rate and prices in the future to current mispricing, with $-\gamma /(1-\gamma)$ the elasticity of the rate with respect to the price ratio $\mathrm{P} / \mathrm{P}^{*}$ along the adjustment path. It is to be noted that as equation (7.2) deals with the equilibrating adjustments to mispricing, or a deviation from parity, this equation does not describe a PPP-type of relation whereby the rate and prices move proportionally. It follows from the way in which the deviation from equilibrium is defined, $d_{t}=q_{t}-\bar{q}$, together with the definition of 
the real exchange rate, $\mathrm{q}=\mathrm{p}-\mathrm{p}^{*}-\mathrm{s}$, that a deviation of either sign results in equilibrating adjustments in the nominal rate and inflation that are negatively correlated. This is the reason why the elasticity in equation $(7.2),-\gamma /(1-\gamma)$, is negative. This elasticity characterises the trade-off between a higher nominal rate and a lower price level, and vice-versa, required to return the real rate back to its equilibrium value $\overline{\mathrm{q}}$.

The schedule FF in Figure 7.1 corresponds to equation (7.2). This schedule passes through the origin and has slope $-\gamma /(1-\gamma)<0$ that reflects the nature of the flexibility of the monetary side of the economy, that is, the relative flexibility of the rate as compared to prices. Going back to equation (7.1), when the nominal rate bears all of adjustment to mispricing, and relative inflation remains unchanged, $\gamma=1$ and $1-\gamma=0$, and the FF schedule is vertical. In the opposite extreme where the rate is fixed, $\gamma=0,1-\gamma=1$ and FF coincides with the horizontal axis. In a fundamental sense, the slope of FF reflects the relative cost of changes in the exchange rate, as compared to price changes. Related considerations include whether or not the country pursues inflation targeting as the objective of monetary policy, and the extent to which the value of the currency is "managed" by the monetary authorities.

One way to obtain some additional information regarding the split between the nominal rate and inflation is to employ the signal extraction technique (Lucas, 1973). Write the real exchange rate as the sum of its two components as

$$
\mathrm{q}=\mathrm{r}+\mathrm{x},
$$

where $\mathrm{r}=\mathrm{p}-\mathrm{p}^{*}$ is the relative price and $\mathrm{x}=-\mathrm{s}=\mathrm{q}-\mathrm{r}$ is the negative nominal rate, the logarithmic foreign currency cost of a unit of domestic currency. ${ }^{12}$ Assume that (i) $r$ is normally distributed with mean $\overline{\mathrm{r}}$ and variance $\sigma_{\mathrm{r}}^{2}$; (ii) $\mathrm{x}$ is normal with mean $\overline{\mathrm{x}}$ and variance $\sigma_{\mathrm{x}}^{2}$; and (iii) $\mathrm{r}$ and $\mathrm{x}$ are orthogonal. Our objective is to forecast x given q. We start with a linear conditional forecast of $\mathrm{r}$,

$$
\mathrm{r}_{\mathrm{f}}=\theta+\kappa q,
$$

where the subscript "f" denotes the forecast. Minimisation of the mean squared error, defined as $\mathrm{E}\left(\mathrm{r}_{\mathrm{f}}-\mathrm{r}\right)^{2}$, gives

$$
\theta=(1-\kappa) \overline{\mathrm{r}}-\kappa \overline{\mathrm{x}}, \quad \kappa=\frac{\sigma_{\mathrm{r}}^{2}}{\sigma_{\mathrm{x}}^{2}+\sigma_{\mathrm{r}}^{2}} .
$$

Substituting the first member of (7.5) into (7.4) yields $r_{f}=(1-\kappa) \bar{r}+\kappa(q-\bar{x})$. Based on equation (7.3), we then have

\footnotetext{
${ }^{12}$ In this paragraph, for notational simplicity we suppress subscript $\mathrm{t}$ for $\mathrm{q}, \mathrm{r}$ and $\mathrm{x}$ (or $\mathrm{s}$ ).
} 


$$
E\left(x_{f} \mid r_{f}\right)=q-r_{f}=(1-\kappa)(q-\bar{r})+\kappa \bar{x} .
$$

The above equation shows that the conditional forecast of the nominal rate is a weighted average of (i) the deviation of the real rate from the long-run relative price and (ii) the historical mean of the nominal rate. If $\sigma_{\mathrm{x}}^{2}=\sigma_{\mathrm{s}}^{2} \gg \sigma_{\mathrm{r}}^{2}$ (as seems to be the case empirically), the second member of (7.5) gives $\kappa \approx 0$, so that the real rate term in (7.6) is accorded most of the weight in forecasting the nominal rate. That is, expression (7.6) becomes $\mathrm{E}\left(\mathrm{x}_{\mathrm{f}} \mid \mathrm{r}_{\mathrm{f}}\right) \approx \mathrm{q}-\overline{\mathrm{r}}$, which implies $\mathrm{E}\left(\Delta \mathrm{x}_{\mathrm{f}} \mid \mathrm{r}_{\mathrm{f}}\right) \approx \Delta \mathrm{q}$. In words, the future change in the real rate is almost entirely brought about by the nominal rate adjusting. In the context of the full-adjustment horizon $\mathrm{H}$, we can then write equation (6.4) as $\Delta_{(\mathrm{H})} \mathrm{s}_{\mathrm{t}+\mathrm{H}} \approx \mathrm{d}_{\mathrm{t}}$, which from equation (7.1), means $\gamma \approx 1$ and the FF schedule in Figure 7.1 is near vertical in this case.

To be able to say where the economy locates on FF, we need more information regarding the link between mispricing, the change in the exchange rate and inflation. This is provided by combining equation (6.4) and identity (6.1) for $\mathrm{h}=\mathrm{H}$ :

$$
\Delta_{(\mathrm{H})} \mathrm{s}_{\mathrm{t}+\mathrm{H}}=\mathrm{d}_{\mathrm{t}}+\Delta_{(\mathrm{H})} \mathrm{r}_{\mathrm{t}+\mathrm{H}} .
$$

To interpret this equation, first consider the overvaluation case, so that $d_{t}>0$. Equation (7.7) then gives the combinations of the future nominal depreciation and higher inflation at home required to eliminate the overvaluation. These combinations are represented by the schedule OO (for overvaluation) in Figure 7.1. This schedule has a slope of 45 degrees and an intercept on the vertical axis of $d_{t}>0$. As the schedule indicates, the initial overvaluation could lead to (i) an equiproportional nominal depreciation with inflation unchanged $\left(\Delta_{(\mathrm{H})} \mathrm{s}_{\mathrm{t}+\mathrm{H}}=\mathrm{d}_{\mathrm{t}}, \Delta_{(\mathrm{H})} \mathrm{r}_{\mathrm{t}+\mathrm{H}}=0\right.$ ); (ii) no change in the nominal rate, with all of the adjustment falling on inflation $\left(\Delta_{(\mathrm{H})} \mathrm{s}_{\mathrm{t}+\mathrm{H}}=0, \Delta_{(\mathrm{H})} \mathrm{r}_{\mathrm{t}+\mathrm{H}}=-\mathrm{d}_{\mathrm{t}}\right)$; or (iii) any combination thereof. The overall equilibrium is given by the point $\mathrm{E}$ in Figure 7.1, the intersection of the $\mathrm{OO}$ and FF schedules. As can be seen, the overvaluation leads to a sharing of the adjustment between a depreciation and a slowing of inflation. It is to be noted that the point $\mathrm{E}$ is uniquely determined by (i) the initial overvaluation, which gives the location of $\mathrm{OO}$; and (ii) the degree of relative flexibility of the exchange rate, as measured by the slope of FF. ${ }^{13}$

\footnotetext{
${ }^{13}$ The intercepts in the two equations in (6.2), $\eta_{\mathrm{s}}^{\mathrm{h}}$ and $\eta_{\mathrm{r}}^{\mathrm{h}}$, represent the changes in the rate and relative inflation that occur for reasons other than mispricing. For simplicity of exposition, in the above we set the intercepts to zero. When
} these terms are nonzero, equation (7.2) becomes

$$
\Delta_{(\mathrm{H})} \mathrm{s}_{\mathrm{t}+\mathrm{H}}=-\frac{\eta_{\mathrm{s}}^{\mathrm{H}}}{1-\gamma}-\left(\frac{\gamma}{1-\gamma}\right) \Delta_{(\mathrm{H})} \mathrm{r}_{\mathrm{t}+\mathrm{H}} .
$$


The above discussion refers to the situation in which the currency is initially overvalued. The undervaluation case is represented in Figure 7.1 by the schedule UU, so that the overall equilibrium is given by the point $\mathrm{E}^{\prime}$. Here the undervaluation leads to a subsequent appreciation and higher inflation.

\section{Is There a Dollar Effect?}

In the above discussion, currency mispricing is identified with the excess of the real exchange rate q over its mean $\overline{\mathrm{q}}$. This reflects the preponderance of nonzero means in Figure 3.3, but Figure 3.5 also reveals that the corresponding mean for the US dollar is also far away from zero and, importantly, there are large swings in the currency below and above the mean. As the 24 other currencies are all expressed in terms of the dollar, they could thus be subject to common shocks due to dollar fluctuations. In this section, we investigate this possibility.

Equation (5.2) defines mispricing as $d_{t}=q_{t}-\bar{q}$. We extend this to allow for a shock that hits all currencies simultaneously at time $t, x_{t}$, by redefining mispricing as $d_{t}^{\prime}=d_{t}-x_{t}$. As it is desirable for mispricing to have a zero expectation, we need $\sum_{t} x_{t}=0$, so that $E\left(d_{t}^{\prime}\right)=0$. Replacing $d_{t}$ on the right-hand side of the predictive regression (5.3) with $d_{t}^{\prime}$, we then obtain

$$
\Delta_{(\mathrm{h})} \mathrm{q}_{\mathrm{t}+\mathrm{h}}=\Sigma_{\tau} \alpha_{\tau, \tau+\mathrm{h}} \mathrm{D}_{\tau, \mathrm{t}}+\phi^{\mathrm{h}} \mathrm{d}_{\mathrm{t}}+\mathrm{u}_{\mathrm{t}}^{\mathrm{h}}
$$

where $\alpha_{\tau, \tau+h}=\eta^{h}-\phi^{h} x_{\tau}$ is the coefficient of the time dummy variable $D_{\tau, \mathrm{t}}$, which takes the value of one if $\tau=\mathrm{t}$, zero otherwise. Note that $\sum_{\mathrm{t}} \mathrm{x}_{\mathrm{t}}=0$ implies $\left(1 / \mathrm{N}^{\mathrm{h}}\right) \Sigma_{\tau} \alpha_{\tau, \tau+\mathrm{h}}=\eta^{\mathrm{h}}$, where $\mathrm{N}^{\mathrm{h}}$ is the number of year coefficients for horizon h, so that the time effects "wash out" over the whole period.

Table 8.1 contains the estimates of equation (8.1) for $h=1, \ldots, 14$. To further allow for common shocks across countries, we use robust standard errors involving a cluster correction whereby the disturbances are equicorrelated (Kleok, 1981). The coefficients of the time dummies are cross-currency averages of the change in q over the relevant horizons, after adjusting for the initial mispricing, as measured by the term $\phi^{\mathrm{h}} \mathrm{d}_{\mathrm{t}}$; averaging over all non-dollar currencies extracts

Thus if $\eta_{\mathrm{s}}^{\mathrm{H}}<0$, which amounts to an "autonomous" depreciation in the rate, the term $-\eta_{\mathrm{s}}^{\mathrm{H}} /(1-\gamma)>0$, and the FF schedule in Figure 7.1 now has a positive intercept on the vertical axis, rather than passing through the origin. Accordingly, a given initial overvaluation is now associated with a larger subsequent depreciation of the rate and a smaller decrease in relative inflation. Vice versa when $\eta_{\mathrm{s}}^{\mathrm{H}}>0$. 
the common dollar effect. ${ }^{14}$ Many of these year coefficients are significant, and for a given horizon, they vary substantially, which points to the importance of the dollar effect. It can be seen from the first row of the table (which refers to $h=1$ ) that the year coefficients are initially positive, then negative and end up positive. This pattern is the mirror image of the path of the US dollar given in Figure 3.5. The year 2008 plays a prominent role as the time effects involving this year, $\alpha_{\tau, 2008}, \tau=1994, \ldots, 2007$, are always among the largest in Table 8.1; these coefficients are the last entries of columns 2-15 of Panel A. Depending on the base year for the comparison, these estimates range from about 8 to 23 percent and are always highly significant. These values reflect the sharp depreciation of the dollar, or the appreciation of other currencies, in 2008 (see Figure 3.5). The importance of the dollar effects is also underscored by the increase in all relevant values of $\mathrm{R}^{2}$ in going from Table 5.1 (where the year effects are excluded) to Table 8.1. The estimates of $\eta^{\mathrm{h}}$ and the slope coefficients given in columns 16 and 17 of Table 8.1 are close to what they were before in Table 5.1. Additionally, in the non-overlapping case, the F-statistics for the hypothesis of full adjustment are not significant for three- and six-year horizons, as before. ${ }^{15}$

Next, we add time effects to the analysis of the split between the nominal rate and prices. In broad outline, this extension reveals little change from the results of Section 6 where the time effects are omitted. In particular, we continue to find that it is difficult to quantity the split in a precise manner. The detailed results are contained in Tables A4-A6 of Appendix A2. But, as before, when the four high-inflation countries are omitted, the nominal rate bears a larger burden of the adjustment than does inflation. However, this finding is somewhat less pronounced than before when the time effects (and the high-inflation countries) were omitted. See Tables A9-A11 of Appendix A3 for details.

\footnotetext{
${ }^{14}$ To illustrate, consider the first entry in column 2 of Panel A of Table 8.1, $10.3\left(\times 100^{-1}\right)$, which is the estimate of $\alpha_{\tau, \tau+h}$ for $\tau=1994, h=1$. From equation (8.1) for this transition, we have $\mathrm{q}_{\mathrm{c}, 1995}-\mathrm{q}_{\mathrm{c}, 1994}=\alpha_{1994,1995}+\phi^{1} \mathrm{~d}_{\mathrm{c}, 1994}=\alpha_{1994,1995}+\phi^{1}\left(\mathrm{q}_{\mathrm{c}, 1994}-\overline{\mathrm{q}}\right)$, where we have set the disturbance at its expected value of zero. Using an obvious notation, we average this equation over currencies: $q_{0,1995}-q_{0,1994}=\alpha_{1994,1995}+\phi^{1}\left(q_{\bullet, 1994}-\bar{q}\right)$. From Table 3.3, the means over the 24 countries of $\mathrm{q}$ in 1994 and 1995 are $\mathrm{q}_{0_{01994}}=-8.28, \mathrm{q}_{\mathrm{o}_{1195}}=-1.58$, while the grand mean over all years and currencies is $\overline{\mathrm{q}}=-18.75\left(\right.$ all $\left.\times 100^{-1}\right)$. Using these values, together with the estimate from Table 8.1 of $\phi^{1}$ of -0.344 (first entry of column 17 ), we have

$$
\alpha_{1994,1995}=q_{\bullet, 1995}-q_{\bullet, 1994}-\phi^{1}\left(q_{\bullet, 1994}-\bar{q}\right)=-1.58+8.28+0.344(-8.28+18.75)=10.30\left(\text { all } \times 100^{-1}\right),
$$

which matches our estimated coefficient of 10.3 percent. Note that if $\phi^{\mathrm{h}}=-1$, as it is under the hypothesis of full adjustment, then the expression for the year coefficient simplifies to $\alpha_{\tau, \tau+\mathrm{h}}=\mathrm{q}_{\boldsymbol{\bullet}_{\tau+\mathrm{h}}}-\overline{\mathrm{q}}$, which is just the deviation of the cross-currency average $\mathrm{q}$ in the relevant year from the grand mean. As the estimated slope coefficients in Panel B of Table 8.1 for horizons of 3-7 years are close to -1, this simplified interpretation applies for these cases.

${ }^{15}$ The F-statistic for $\mathrm{h}=7$ is now insignificant also.
} 
To summarise, the persistent swings of the dollar play a role in the adjustment to mispricing of non-dollar currencies. But even when these effects are allowed for, in broad outline the results of Sections 5 and 6 continue to hold: Within a period of three to six years, currency mispricing is more or less eliminated.

\section{The Burgernomics Literature}

This section reviews the literature on the Big Mac Index. Cumby (1996) is widely known as the first burgernomics paper and was originally a 1995 Georgetown University working paper. Almost at the same time however, the paper by Ong (1995) was presented at the ANU/UWA PhD Conference in Economics and Business in Perth, held in November 1995, and later published as Ong (1997). As far as we are aware, there are in total 22 academic papers and one book on the Big Mac Index/burgernomics. Table 9.1 lists these publications in chronicle order. These papers can be broadly grouped into two categories, (i) the basic foundations and (ii) "adventurous" applications.

Regarding basic foundations, Cumby (1996) finds out that the half-life of deviations from the Big Mac parity is about one year, and these deviations provide significant information for forecasting exchange rates and Big Mac prices. Lutz (2001) applies Cumby's methodology to 12 price series published by the bank UBS as well as aggregate CPI data. Click (1996), Fujiki and Kitamura (2003) and Caetano et al. (2004) find country incomes to be important in explaining deviations from Big Mac PPP. Yang (2004) uses the BMI to evaluate the Chinese yuan and finds that currencies of low-income countries are overvalued due to the insufficient weight accorded to nontradables. Ong (1997) finds that Big Macs are surprisingly accurate in tracking exchange rates over the long run. She also proposes the "No-Frills Index" by excluding nontradable components from the Big Mac Index, and establishes that this performs better than the BMI. Using Big Mac prices, Ong (1998a) analyses the Asian currency crisis, while Ong (1998b), Ong and Mitchell (2000), and Ashenfelter and Jurajda (2001) compare wages in different countries. Ong (2003) is the only book on burgernomics, and this comprises a series of papers by her and coauthors. Pakko and Pollard (1996, 2003) conclude that Big Macs are a useful but flawed PPP measure as deviations from absolute PPP are persistent while those from relative PPP are transitory. Chen et al. (2007) compare the behaviour of Big Mac prices with CPIs and find that the BMI supports the validity of PPP better than the CPI does. Parsley and Wei (2007), discussed previously in Section 3, relate the price of a Big Mac to the costs of its ingredients and find that the speed of convergence of the overall Big Mac real exchange rate is bracketed by that for its tradable and nontradable inputs.

Annaert and Ceuster (1997) pursue a different line of research in one of the first adventurous applications of burgernomics. They construct currency portfolios selected on the basis of the Big 
Mac Index whereby undervalued currencies are bought and undervalued ones sold, and their results show that Big Macs can serve as a useful international asset allocator. Given their volatility, exchange rates are notoriously difficult to forecast. As the previous US Fed Chairman, Alan Greenspan (2004), puts it, "despite extensive efforts on the part of analysts, to my knowledge, no model projecting directional movements in exchange rates is significantly superior to tossing a coin." There is now an emerging stream of burgernomics that investigates whether the BMI can be used to forecast exchange rates. Lan (2006) uses Big Mac prices to forecast the whole distribution of future exchange rates, employing a novel iterative approach to adjust for econometric problems associated with the estimation of dynamic panel models where the number of observations is not large. The provision of the whole distribution emphasises forecast uncertainty that enables users to make financial decisions in an informed manner with the appropriate degree of caution. Clements and Lan (2010) extend Lan (2006) and use Monte Carlo simulations to provide real-time exchangerate forecasts for any horizon into the future.

\section{Concluding Comments}

The Economist magazine advocates as a currency pricing rule the formula $\mathrm{S}=\mathrm{P} / \mathrm{P}^{*}$, where $\mathrm{S}$ is the exchange rate (the domestic currency cost of one US dollar), $\mathrm{P}$ is the price of a Big Mac hamburger in the country in question and $\mathrm{P}^{*}$ is the price in the US. Thus an increase in the domestic price, relative to the US price, leads to a depreciation of the domestic currency. The rule is a precise, numerical relationship between the exchange rate and the relative price that can be used to identify mispricing of the currency in a quick and convenient way. This is a novel and controversial application of the purchasing power parity theory of exchange rates that is known as the Big Mac Index and is published annually by The Economist for a large number of currencies.

The cost of a full-page advertisement in The Economist must be something like \$US50,000. For the magazine to continue to publish an annual article on the Big Mac Index for more than two decades means that it is worth this opportunity cost, at least in the mind of the editor. This paper assessed the broader value of the BMI by analysing its properties and ability to track exchange rates. The major findings of the paper are:

- The index is a biased predictor of currency values.

- Once the bias is allowed for, the index tracks exchange rates reasonably well over the medium to longer term in accordance with relative purchasing power parity theory.

- The index is at least as good as the industry standard, the random walk model, in predicting future currency values for all but short-term horizons. 
- Future nominal exchange rates are more responsive than prices to currency mispricing.

Thus, while it is not perfect, as the cost of the magazine is less than \$US10, the index seems to provide good value for money. In showing that relative prices act as an "attractor" or "anchor" for exchange rates over the longer term, our results also have implications for exchange-rate economics: As currencies of high (low)-inflation countries depreciate (appreciate), over longer horizons economic fundamentals tend to dominate currency pricing. 


\section{APPENDIX}

\section{A1. The Big Mac Data}

The Economist magazine has been publishing the Big Mac index (henceforth, BMI) on an annual basis since 1986. The data presented in Tables A1, A2 and A3 are compiled from a number of issues of the magazine from 1986 to 2008. They consist of, respectively, the implied PPP exchange rates, nominal exchange rates and real exchange rates of all countries that have appeared at least once in The Economist. Note that the data for 2002-08 is also based on information contained in the on-line BMI articles found on the Economist website. Some of this information is not contained in the hard copy versions of the articles.

In years when countries were not included in either the printed or online versions of the articles the corresponding cells of Tables A1, A2 and A3 have been left blank. Note also that to ensure internal consistency, the implied PPP (IPPP) exchange rates were calculated from the Big Mac (BM) prices. The only exceptions to this rule are for 2004 and 2005, when a slightly different layout was used for the BMI articles. As nominal exchange rates and prices were not quoted in these years, we used the IPPP values and prices to reverse engineer the nominal exchange rates. The majority of exchange rates in the BMI articles are expressed in terms of the domestic currency price of one US dollar. However, from 1993 onwards, the British pound, the Euro and the Irish pound were quoted in reciprocal form, which we inverted.

We have made adjustments for five discrepancies found in the published data:

(1) Brazil 1986. The prices of a BM is listed by The Economist as Cz\$2.5 in Brazil and $\$ 1.6$ in the US. The IPPP is $2.5 / 1.6=1.5625$. However, the article lists the IPPP as 7.80, suggesting that the Brazilian price should be $7.8 \times 1.6=12.48$. As the article proceeds to use 7.8 as the IPPP for the overvaluation calculation, it seems that the error lies in the price, so we use 12.48 for this price.

(2) Chile 1999. The last digit of the Chilean BM price is omitted from the article: The price is recorded as 1,25, whereas in all other years the price is around 1250 pesos. Using $\mathrm{P}=\mathrm{IPPP} \times \mathrm{P}^{*}$ with $\mathrm{IPPP}=518$ and $\mathrm{P}^{*}=\$ 2.43$, we have $518 \times 2.43=1258.74$. Thus, the omitted last digit is 9 (rounded up from 8.74), so we use 1,259 for this price.

(3) France 1999. The prices are listed as 8.5 francs and 2.43 dollars, while the IPPP is 7.20. These values are not internally consistent. It seems that the price in France should be $7.20 \times 2.43=17.496$ francs. As this price is much more inline with previous values, we use 7.2 as the IPPP value. 
(4) Denmark 1998. The IPPP rate is listed as 9.28, while using the listed prices, we computed it at 9.297. To keep things internally consistent, we use the latter rate.

(5) France 1986. As with Denmark 1998, there is a small deviation between the listed IPPP and our internally consistent calculated value, 10.30 vs 10.25 . Again, we use the internally consistent calculated value. ${ }^{16}$

In the text of the paper, we use the Big Mac data for 24 countries/areas over the period of 1994 to 2008 , so that the total number of observations is $24 \times 15=360$. Tables $3.1-3.3$ show the respective implied PPP exchange rates, nominal exchange rates and real exchange rates. In two instances, Big Mac prices and nominal exchange rates are missing: New Zealand 1994 and the Czech Republic 1999. In these cases, nominal exchange rates are taken from the International Monetary Fund's International Financial Statistics database (http://www.imfstatistics.org/imf/). The Big Mac prices are computed on the basis of the one-year percentage change in the Consumer Price Index (henceforth, CPI), again taken from IFS. For example, the IPPP for New Zealand in 1994 is computed as $[\mathrm{P} /(1+\pi)] / \mathrm{P}^{*}$, where $\mathrm{P}$ is the 1995 price of a BM in New Zealand, $\pi$ is the $1994 \mathrm{CPI}$ rate of inflation in New Zealand and $\mathrm{P}^{*}$ is the \$US 1994 price of a BM in the US.

As the euro was not introduced until 1999, official data are unavailable for this currency from 1994 to 1998. However, the Big Mac data for the six member countries included in our data -Belgium, France, Germany, Italy, Holland, and Spain -- exist for the pre-euro period. For the years 1994-98 we estimated the euro exchange rate as follows. Let $S_{c t}$ be the nominal exchange rate (the domestic-currency cost of \$US1) for European country $c \quad(c=1, \ldots, 6)$ in year $t$ $(t=1994, \ldots, 1998)$, the values of which are listed in The Economist, and $E_{c t}$ be the corresponding exchange rate for the European Currency Unit (the currency basket that was the effective predecessor to the Euro), which is available on Inforeuro (http://ec.europa.eu/budget/inforeuro/index.cfm?Language=en). Then, $\mathrm{S}_{\mathrm{ct}} / \mathrm{E}_{\mathrm{ct}}$ is the cost of the dollar in terms of ECUs. Using the April ECU rates, the resulting values of $\mathrm{S}_{\mathrm{ct}} / \mathrm{E}_{\mathrm{ct}}$ are very nearly the same for each country. The small differences are likely to be the result of rounding errors or changes in the currency values that occurred between the end-of-month (April) exchange rates on Inforeuro and the days within the month of April to which the data contained in The Economist articles refer (the $9^{\text {th }}, 15^{\text {th }}, 27^{\text {th }}, 12^{\text {th }}$ and $11^{\text {th }}$ of April for 1994-98, respectively). These differences are eliminated by averaging, so the euro exchange rate is defined as $E_{t}=(1 / 6) \sum_{c=1}^{6} S_{c t} / E_{c t}$. As $P_{c t}$

\footnotetext{
${ }^{16}$ Items 4 and 5 above are the only instances where internally calculated IPPPs differ from the Economist's - internal consistent calculations yield more decimal places, but when rounded the figures are identical.
} 
is the price of a BM in country $\mathrm{c}$ in terms of domestic currency, $\mathrm{P}_{\mathrm{ct}} / \mathrm{E}_{\mathrm{ct}}$ is the price in ECUs (euros). For the period 1994-98, we define "the" price of a BM in Europe as the average over the six countries, so the corresponding IPPP is the ratio of $(1 / 6) \sum_{c=1}^{6} \mathrm{P}_{c t} / \mathrm{E}_{\mathrm{ct}}$ to the US price.

\section{A2. Additional Results with Time Effects}

Tables 6.1 and 6.2 of the text give the results for the predictive regressions when the real rate is decomposed into the nominal rate and relative inflation components. Tables A4-A6 of this Appendix give the corresponding results when time effects are added. As mentioned in the text, the inclusion of the time effects has little impact on the results. When all 24 countries are considered, it remains difficult to split precisely the overall adjustment of the real exchange rate between the nominal rate and prices.

\section{A3. High Inflation and Monetary Turmoil}

In 1994, 1995 and 1998, the Brazilian real, Polish zloty and Russian rouble, respectively, were redenominated. This can be seen from the prices and exchange rates for these countries in Tables 3.1 and 3.2, as well as in the volatility measures of Figure 3.2. Additionally, following the floating of its currency in 2002, there was considerable monetary turmoil in Argentina. What is the impact of these episodes on the performance of the Big Mac Index? As large increases in prices tend to be offset by corresponding depreciations of the currency that restore the real rate, at least as an approximation, the impact of high inflation and redenominations is likely to be less pronounced when the real rate is analysed. In what follows, we thus redo some of the analysis that involves the nominal exchange rate.

We start with predictive regressions of Section 6 of the paper,

$$
-\Delta_{(\mathrm{h})} \mathrm{s}_{\mathrm{t}+\mathrm{h}}=\eta_{\mathrm{s}}^{\mathrm{h}}+\phi_{\mathrm{s}}^{\mathrm{h}} \mathrm{d}_{\mathrm{t}}+\mathrm{u}_{\mathrm{st}}^{\mathrm{h}}, \quad \Delta_{(\mathrm{h})} \mathrm{r}_{\mathrm{t}+\mathrm{h}}=\eta_{\mathrm{r}}^{\mathrm{h}}+\phi_{\mathrm{r}}^{\mathrm{h}} \mathrm{d}_{\mathrm{t}}+\mathrm{u}_{\mathrm{rt}}^{\mathrm{h}},
$$

where, for horizon $h, \eta_{s}^{\mathrm{h}}, \phi_{s}^{\mathrm{h}}, \eta_{\mathrm{r}}^{\mathrm{h}}$ and $\phi_{\mathrm{r}}^{\mathrm{h}}$ are parameters, $\mathrm{d}_{\mathrm{t}}$ is current mispricing defined by equation (5.2), and $\mathrm{u}_{\mathrm{st}}^{\mathrm{h}}$ and $\mathrm{u}_{\mathrm{rt}}^{\mathrm{h}}$ are zero-mean error terms. Table A7 presents the estimates of model (A3.1) with the four high-inflation countries omitted. In comparison with the results when these four countries were included (Table 6.1), there is now a tendency for $\left|\phi_{\mathrm{s}}^{\mathrm{h}}\right|$ to be higher and $\left|\phi_{\mathrm{r}}^{\mathrm{h}}\right|$ lower, making $\phi_{\mathrm{s}}^{\mathrm{h}} /\left(\phi_{\mathrm{s}}^{\mathrm{h}}+\phi_{\mathrm{r}}^{\mathrm{h}}\right)$ closer to unity, so that the nominal rate does more of the adjusting. Moreover, the estimates are more precisely determined and intercepts (the autonomous changes in exchange rates and prices) are now considerably smaller. 
As discussed in Section 6 of the text, when there is complete adjustment at horizon $\mathrm{H}$, the intercepts and slopes of model (A3.1) satisfy $\eta_{\mathrm{s}}^{\mathrm{H}}+\eta_{\mathrm{r}}^{\mathrm{H}}=0, \phi_{\mathrm{s}}^{\mathrm{H}}+\phi_{\mathrm{r}}^{\mathrm{H}}=-1$. The two equations in (A3.1) with this cross-equation restriction imposed can be estimated by SURE and Table A8 contains the results when the four countries are omitted. Comparing these results to those of Table 6.2, again we see a substantially clearer picture with the nominal rate doing the vast bulk of the adjustment, the values of the intercepts falling and the parameters being better determined.

Tables A4-A6 above give the results, for all 24 countries, pertaining to the split between the nominal rate and prices when time effects are added. Tables A9-A11 contain the corresponding results when the four high-inflation countries are omitted. Now, there is a slight tendency for there to be a more equal sharing of the adjustment between the nominal rate and inflation, but still the exchange rate does the majority of the work.

The above discussion of the results when the high-inflation countries are excluded involves the additional dimension of time effects both included and excluded. To assist with an understanding of the presentation of these results, Table A12 provides an analytical overview of the structure of the various pairwise comparisons. Thus, for example, the first entries of columns 2 and 3 of this table refer to Tables 6.1 and A7. A comparison of these two tables reveals the impact of the high inflation countries on the results pertaining to the effect of mispricing on the nominal exchange rate, when time effects are excluded. Similarly, from the first two elements of column 3, A7 and A9, the impact on the nominal rate results of the inclusion of time effects, when the highinflation countries are excluded, is given by the comparison between Tables A7 and A9. 


\section{REFERENCES}

Annaert, J., and M. J. K. Ceuster (1997). "The Big Mac: More than a Junk Asset Allocator?" International Review of Financial Analysis 6: 79-192.

Ashenfelter, O., and S. Jurajda (2001). "Cross-country Comparison of Wage Rates: The Big Mac Index." Unpublished paper, available at http://economics.uchicago.edu/download/bigmac.pdf.

Balassa, B. (1964). "The Purchasing Power Parity Doctrine: A Reappraisal." Journal of Political Economy 72: 584-96.

Caetano, S., G. Moura and S. Da Silva (2004). "Big Mac Parity, Income and Trade.” Economics Bulletin 6: 1-8.

Chen, C.-F., C.-H. Shen and C.-A. Wang (2007). "Does PPP hold for Big Mac Prices or the Consumer Price Index? Evidence from Panel Cointegration.” Economics Bulletin 6: 1-15.

Clementi, F., M. Gallegati and A. Palestrini (2010). "A Big Mac Test of Price Dynamics and

Dispersion Across Euro Area." Available at http://ssrn.com/abstract=1536700.

Clements, K. W., and Y. Lan (2010). "A New Approach to Forecasting Exchange Rates.” Journal of International Money and Finance doi:10.1016/j.jimf.2010.03.009.

Click, R. W. (1996). "Contrarian MacParity." Economics Letters 53: 209-12.

Cumby, R. E. (1996). "Forecasting Exchange Rates and Relative Prices with the Hamburger Standard: Is What You Want What You Get with McParity?" NBER Working Paper 5675.

Flood, R., and M. Taylor (1996). "Exchange Rate Economics: What's Wrong with the Conventional Macro Approach?" In J. Frankel, G. Galli and A. Giocannini (eds) The Microstructure of Foreign Exchange Markets. Chicago: The University of Chicago Press. Pp. 261-94.

Frenkel, J. A., and M. L. Mussa (1980). "The Efficiency of the Foreign Exchange Market and Measures of Turbulence." American Economic Review 70: 374-81.

Froot, K. A., and K. Rogoff (1995). "Perspectives on PPP and Long-Run Real Exchange Rates." In G. Grossman and K. Rogoff (eds) Handbook of International Economics. Volume 3. Amsterdam: North-Holland. Pp. 1647-88.

Fujiki, H., and Y. Kitamura (2003). “The Big Mac Standard: The Statistical Illustration.” Discussion Paper 446, Institute of Economic Research, Hitotsubashi University.

Fukumoto,Y. (2009). "International Price Dispersions of the Big Mac and Economic Integration." Mimeo, Osaka University of Economics.

Greenspan, A. (2004). "Remarks." Panel discussion on "The Euro in Wider Circles", European Banking Congress 2004, Frankfurt, November 19.

Isard, P. (1995). Exchange Rate Economics. Cambridge: Cambridge University Press.

James, C. (2007a). "The CommSec iPod Index: Global Comparisons." CommSec Economic Insight, 18 January 2007.

James, C. (2007b). "The CommSec iPod Index: Consumers Win as Prices Fall: Global Comparisons and Currency Changes." CommSec Economic Insight, 18 May 2007. Available at http:// images.comsec.com.au/ipo/UploadedImages/ipodindexe771774183be45349abe6efea3d52610.pd f. Consulted on 10 September 2007.

Kleok, T. (1981). "OLS Estimation of a Model where a Microvariable is Explained by Aggregates and Contemporaneous Disturbances are Equicorrelated." Econometrica 49: 205-207.

Lan, Y. (2002). "The Explosion of Purchasing Power Parity." In M. Manzur (ed) Exchange Rates, Interest Rates and Commodity Prices. Elgar: Cheltenham, UK. Pp. 9-38.

Lan, Y. (2006). "Equilibrium Exchange Rates and Currency Forecasts: A Big Mac Perspective." International Economics and Finance Journal 1: 291-311.

Lan, Y., and L. L. Ong (2003). "The Growing Evidence on Purchasing Power Parity.” In L. L. Ong The Big Mac Index: Applications of Purchasing Power Parity. UK: Palgrave MacMillan. Pp. 29-50. 
Lothian, J. R. (1985). "Equilibrium Relationships Between Money and Other Economic Variables." American Economic Review 75: 828-35.

Lucas, R. E. (1973). "Some International Evidence on Output-Inflation Tradeoffs." $\underline{\text { American }}$ Economic Review 63: 326-34.

Lutz, M. (2001). "Beyond Burgernomics and MacParity: Exchange-Rate Forecasts Based on the Law of One Price." Unpublished manuscript, University of St. Gallen.

MacDonald, R. (2007). Exchange Rate Economics: Theories and Evidence. Milton Park, UK: Routledge.

MacDonald, R., and J. L. Stein (1999). "Introduction: Equilibrium Exchange Rates." In R. MacDonald and J. L. Stein (eds) Equilibrium Exchange Rates. Boston: Kluwer.

Meese, R. A. and K. Rogoff (1983a). "Empirical Exchange Rate Models of the Seventies: Do They Fit Out of Sample?" Journal of International Economics 14: 3-24.

Meese, R. A. and K. Rogoff (1983b). "The Out-of-Sample Failure of Empirical Exchange Rates: Sampling Error or Misspecification?" In J. A. Frenkel (ed) Exchange Rates and International Macroeconomics. Chicago: University of Chicago Press.

Monson, T. D. (undated). “The Big Mac Index Revisited.” Mimeo, Michigan Technological

University.

Obstfeld, M. (1995). "International Currency Experience: New Lessons and Lessons Relearned." Brookings Papers on Economic Activity 1: 119-220.

Ong, L. L. (1995). "Burgernomics: the Economics of the Big Mac Standard." Presented at the ANU/UWA PhD Conference in Economics and Business, The University of Western Australia.

Ong, L. L. (1997). "Burgernomics: the Economics of the Big Mac Standard." Journal of International Money and Finance 16: 865-78.

Ong, L. L. (1998a). "Burgernomics and the ASEAN Currency Crisis." Journal of the Australian Society of Security Analysts 1: 15-16.

Ong, L. L. (1998b). "Big Mac and Wages to Go, Please: Comparing the Purchasing Power of Earnings around the World." Australian Journal of Labour Economics 2: 53-68.

Ong, L. L. (2003). The Big Mac Index: Applications of Purchasing Power Parity. Houndmills: Palgrave Macmillan.

Ong, L. L., and J. D. Mitchell (2000). "Professors and Hamburgers: An International Comparison of Real Academic Salaries." Applied Economics 32: 869-76.

Pakko, M. R., and P. S. Pollard (1996). "For Here to Go? Purchasing Power Parity and the Big Mac." Federal Reserve Bank of St. Louis Review 78: 3-21.

Pakko, M. R., and P. S. Pollard (2003). "Burgernomics: A Big Mac Guide to Purchasing Power Parity." Federal Reserve Bank of St. Louis Review 85: 9-27.

Parsley, D., and S. Wei (2007). "A Prism into the PPP Puzzles: The Micro-Foundations of Big Mac Real Exchange Rates.” Economic Journal 117: 1336-56.

Rogoff, K. (1996). “The Purchasing Power Parity Puzzle.” Journal of Economic Literature 34: 647668.

Samuelson, P. A. (1964). "Theoretical Notes on Trade Problems". Review of Economics and Statistics 46: 145-54.

Sarno, L., and M. P. Taylor (2002). The Economics of Exchange Rates. Cambridge: Cambridge University Press.

Sjaastad, L. A. (1980). “Commercial Policy 'True Tariffs' and Relative Prices.” In J. Black and B. V. Hindley (eds) Current Issues in Commercial Policy and Diplomacy. London: Macmillan.

Taylor, A. M., and M. P. Taylor (2004). "The Purchasing Power Parity Debate." Journal of Economic Perspectives 18: 135-58.

Taylor, M. P. (2006). "Real Exchange Rates and Purchasing Power Parity: Mean Reversion in Economic Thought." Applied Financial Economics 16: 1-17. 
Winkels, R. D. A. (2009). “The Big Mac Portfolio.” Masters Thesis, Tilburg University.

Yang, J. (2004). "Nontradables and the Valuation of RMB: An Evaluation of the Big Mac Index." China Economic Review 15: 353-59. 
FIGURE 1.1

EXCHANGE RATES AND PRICES, 1973-2007

\section{A. United Kingdom}

\section{GBP/USD}

\section{Prices}

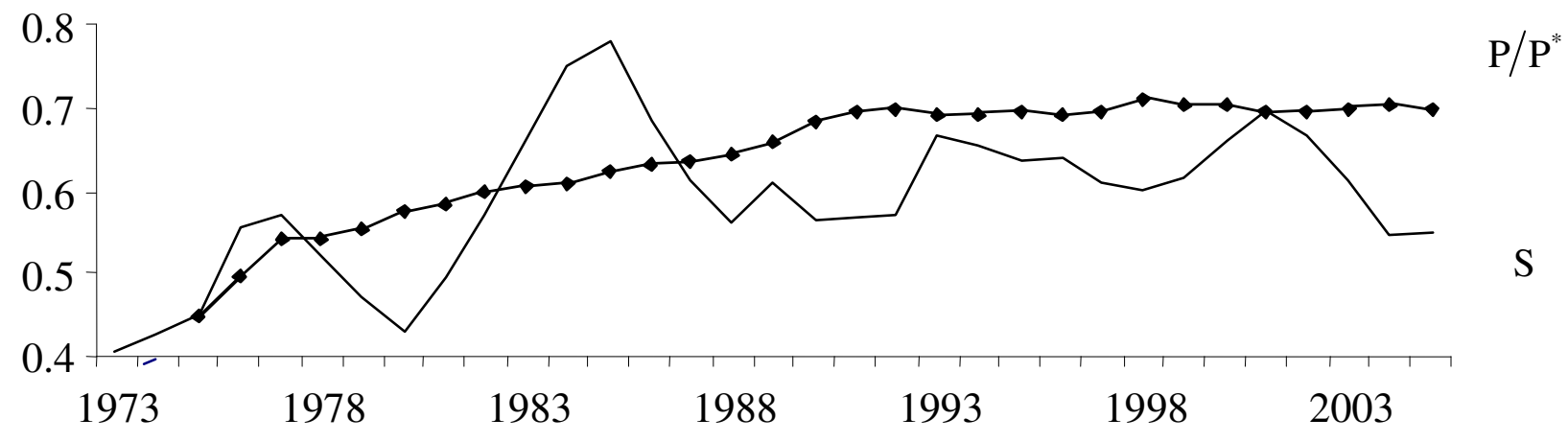

B. Japan

\section{JPY/USD}

\section{Prices}

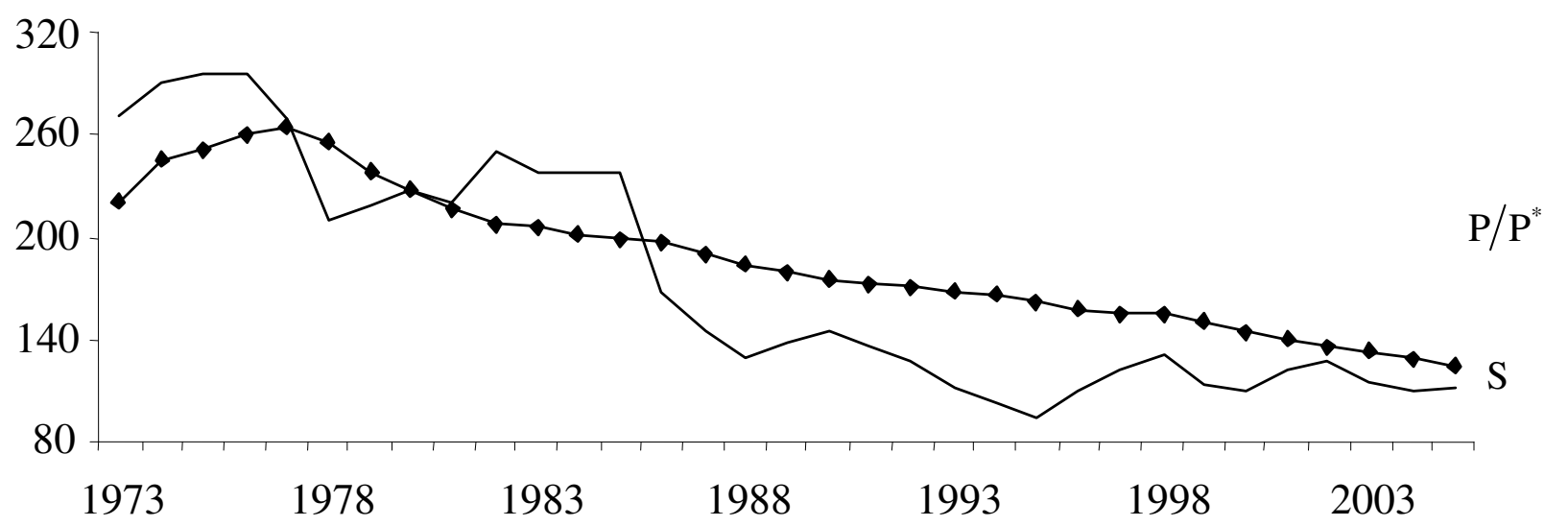

Sources: International Monetary Fund International Financial Statistics, and Pacific Exchange Rate Service (http://pacific.commerce.ubc.ca/xr/data.html).

Note: The price levels are consumer price indices. The base year for each country (Britain 2002, Japan 2006) is chosen to minimize the deviations from parity, $\mathrm{S}-\mathrm{P} / \mathrm{P}^{*}$. This amounts to assuming that PPP holds on average over the 33 years, and determines nothing more than the "average" height of the relative price curve. 


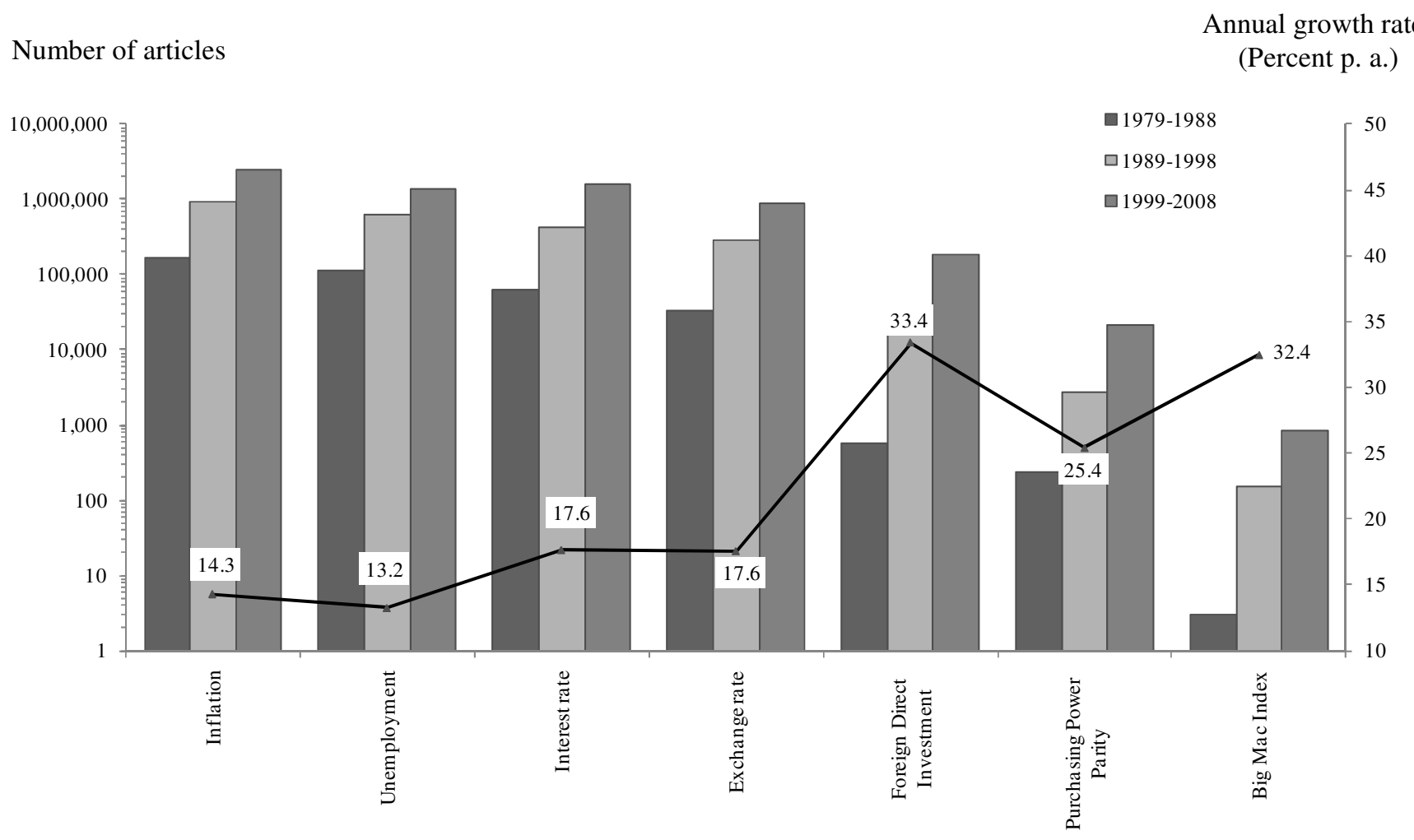

Source: Factiva

(http://global.factiva.com/sb/default.aspx?NAPC=S\&fcpil=en).

Keyword search conducted in July 2010. 
FIGURE 2.1

\section{THE GEOMETRY OF PPP}

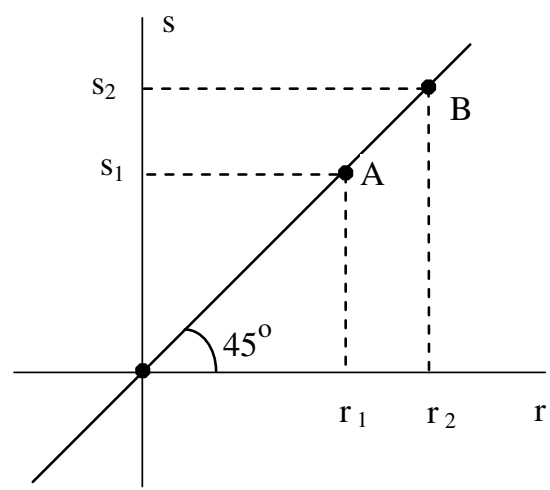

A. Absolute PPP

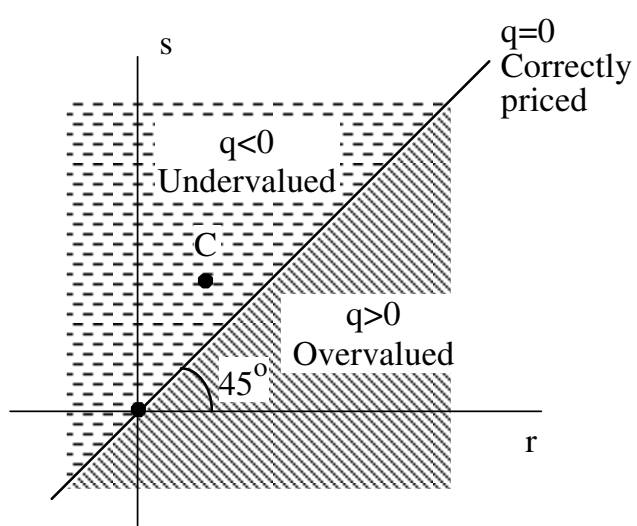

B. Relative PPP
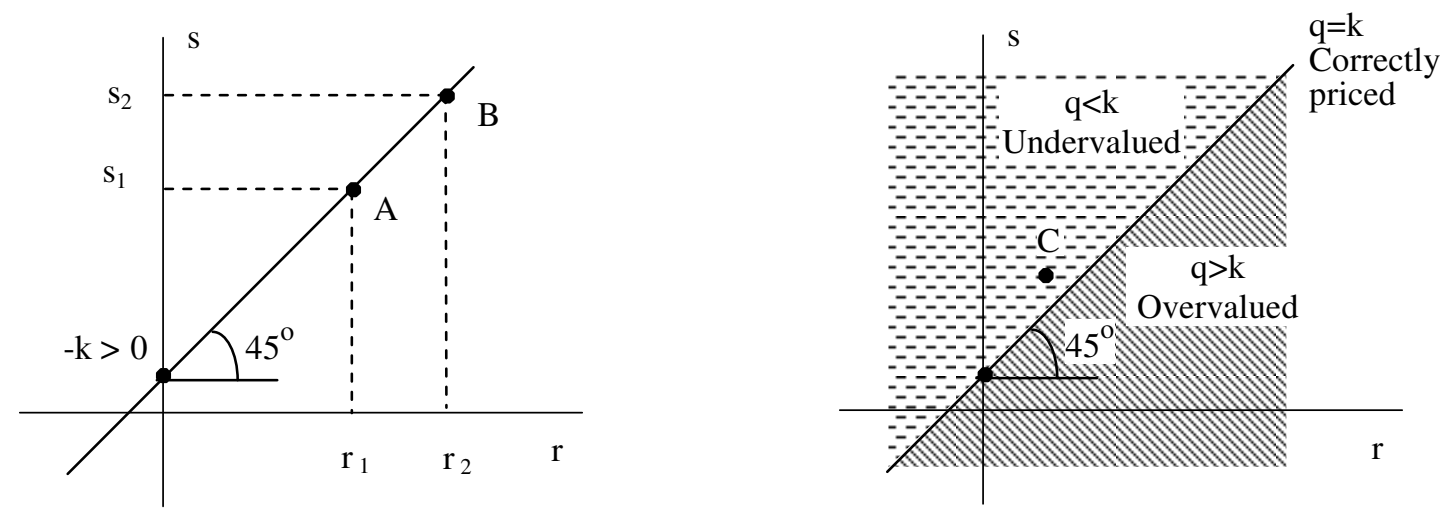

C. Stochastic PPP
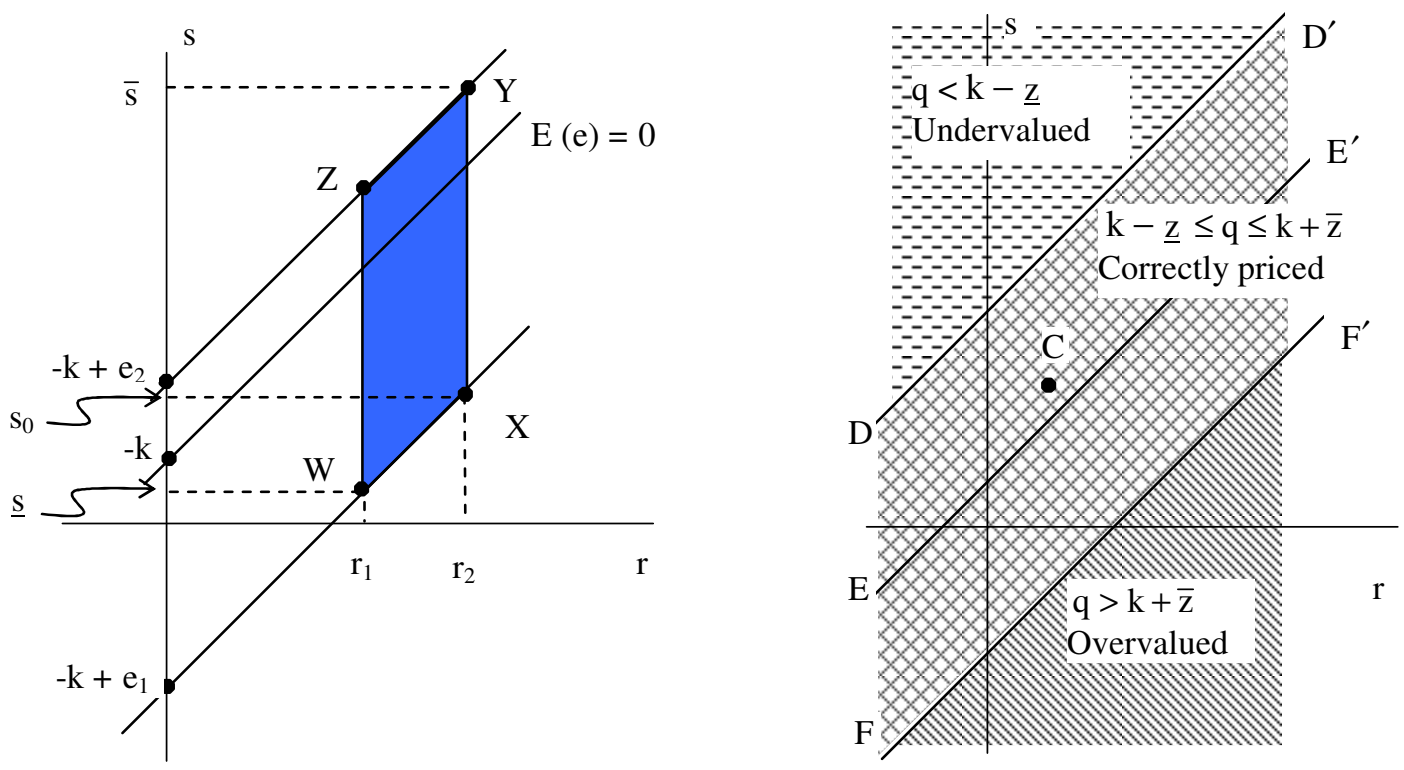
FIGURE 3.1

\section{EXAMPLE OF BIG MAC ARTICLE}

\section{The Big Mac Index}

\section{Sandwiched}

Burgernomics says currencies are very dear in Europe but very cheap in Asia

FVER since the credit storms first broke Llast August, the prices of stocks, bonds, gold and other investment assets have been blown this way and that. Currencies have been pushed around too. Did this buffeting bring them any closer to their underlying fair value? Not according to the Big Mac Index, our lighthearted guide to exchange rates. Many currencies look more out of whack than in July 2007, when we last compared burger prices.

The Big Mac Index is based on the theory of purchasing-power parity (PPP),

\begin{tabular}{|c|c|c|c|c|c|}
\hline \multicolumn{6}{|c|}{ The McCurrency menu } \\
\hline \multirow[b]{3}{*}{ (1) } & \multicolumn{2}{|c|}{$\begin{array}{l}\text { ndard } \\
\qquad \text { Big Mac prices }\end{array}$} & \multirow{3}{*}{$\begin{array}{c}\text { Implied } \\
\text { pppt } \\
\text { of the } \\
\text { dollar } \\
\text { (4) }\end{array}$} & \multirow{3}{*}{$\begin{array}{c}\text { actual } \\
\text { exchange } \\
\text { rate } \\
(5)\end{array}$} & \multirow{3}{*}{$\begin{array}{c}\text { Under (- } \\
\text { /over(+) } \\
\text { valuation } \\
\text { e against } \\
\text { dollar } \\
\text { (6) }\end{array}$} \\
\hline & $\begin{array}{l}\text { In local } \\
\text { currency }\end{array}$ & in dollars* & & & \\
\hline & (2) & (3) & & & \\
\hline United States $₹$ & $\$ 3.57$ & 3.57 & - & - & \\
\hline Argentina & Peso 11.0 & 3.64 & 3.08 & 3.02 & +2 \\
\hline Australia & $A \$ 3.45$ & 3.36 & 0.97 & 1.03 & -6 \\
\hline Brazil & Real 7.50 & 4.73 & 2.10 & 1.58 & +33 \\
\hline Britain & f2.29 & 4.57 & 1.565 & 2.00 & +28 \\
\hline Canada & $C \$ 4.09$ & 4.08 & 1.15 & 1.00 & +14 \\
\hline Chile & Peso 1,550 & 3.13 & 434 & 494 & -12 \\
\hline China & Yuan 12.5 & 1.83 & 3.50 & 6.83 & -49 \\
\hline Czech Republic & Koruna 66.1 & 4.56 & 18.5 & 14.5 & +28 \\
\hline Denmark & DK28.0 & 5.95 & 7.84 & 4.70 & +67 \\
\hline Egypt & Pound 13.0 & 2.45 & 3.64 & 5.31 & -31 \\
\hline Euro Area** & $€ 3.37$ & 5.34 & $1.06 \mathrm{tt}$ & 1.59 & +50 \\
\hline Hong Kong & HK\$13.3 & 1.71 & 3.73 & 7.80 & -52 \\
\hline Hungary & Forint 670 & 4.64 & 187.7 & 144.3 & +30 \\
\hline Indonesia & Rupiah 18,700 & 2.04 & 5,238 & 9,152 & -43 \\
\hline Japan & Yen 280 & 2.62 & 78.4 & 106.8 & -27 \\
\hline Malaysia & Ringgit 5.50 & 1.70 & 1.54 & 3.2 & -52 \\
\hline Mexico & Peso 32.0 & 3.15 & 8.96 & 10.2 & -12 \\
\hline New Zealand & NZ\$ $\$ .90$ & 3.72 & 1.37 & 1.32 & +4 \\
\hline Norway & Kroner 40.0 & 7.88 & 11.2 & 5.08 & +121 \\
\hline Poland & Zloty 7.00 & 3.45 & 1.96 & 2.03 & -3 \\
\hline Russia & Rouble 59.0 & 2.54 & 16.5 & 23.2 & -29 \\
\hline Saudi Arabia & Riyal 10.0 & 2.67 & 2.80 & 3.75 & -25 \\
\hline Singapore & $\$ \$ 3.95$ & 2.92 & 1.11 & 1.35 & -18 \\
\hline South Africa & Rand 16.9 & 2.24 & 4.75 & 7.56 & -37 \\
\hline South Korea & Won 3,200 & 3.14 & 896 & 1,018 & -12 \\
\hline Sweden & SKr 38.0 & 6.37 & 10.6 & 5.96 & +79 \\
\hline Switzerland & SFr6.50 & 6.36 & 1.82 & 1.02 & +78 \\
\hline Taiwan & NT\$75.0 & 2.47 & 21.0 & 30.4 & -31 \\
\hline Thailand & Baht 62.0 & 1.86 & 17.4 & 33.4 & -48 \\
\hline Turkey & lire 5.15 & 4.32 & 1.44 & 1.19 & +21 \\
\hline UAE & Dirhams 10.00 & 2.72 & 2.80 & 3.67 & -24 \\
\hline Colombia & Peso 7000.00 & $3.89 \quad 1$ & 1960.78 & 1798.65 & 9 \\
\hline Costa Rica & Colones 1800.00 & 3.27 & 504.20 & 551.02 & -8 \\
\hline Estonia & Kroon 32.00 & 3.24 & 8.96 & 9.87 & -9 \\
\hline Iceland & Kronur 469.00 & 5.97 & 131.37 & 78.57 & 67 \\
\hline Latvia & Lats 1.55 & 3.50 & 0.43 & 0.44 & -2 \\
\hline Lithuania & Litas 6.90 & 3.17 & 1.93 & 2.18 & -11 \\
\hline Pakistan & Rupee 140.00 & 1.97 & 39.22 & 70.90 & -45 \\
\hline Peru & New Sol 9.50 & 3.35 & 2.66 & 2.84 & -6 \\
\hline Philippines & Peso 87.00 & 1.96 & 24.37 & 44.49 & -45 \\
\hline Slovakia & Koruna 77.00 & 4.03 & 21.57 & 19.13 & 13 \\
\hline Sri Lanka & Rupee 210.00 & 1.95 & 58.82 & 107.55 & -45 \\
\hline Ukraine & Hryvnia 11.00 & 2.39 & 3.08 & 4.60 & -33 \\
\hline Uruguay & Peso 61.00 & 3.19 & 17.09 & 19.15 & -11 \\
\hline & $\begin{array}{l}\text { asing-power parity; lo } \\
\text { "New York, Chicago, At } \\
\text { "Weighted avera }\end{array}$ & $\begin{array}{l}\text { ocal price divid } \\
\text { tlanta and San } \\
\text { age of prices in }\end{array}$ & $\begin{array}{l}\text {-At cu } \\
\text { ided by price } \\
\text { an Francisco } \\
\text { in euro aree }\end{array}$ & 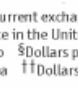 & $\begin{array}{l}\text { ange rates } \\
\text { ited States } \\
\text { per pound } \\
\text { is per euro }\end{array}$ \\
\hline Donal & idd's; The Economist & & & & \\
\hline
\end{tabular}

which says that exchange rates should move to make the price of a basket of goods the same in each country. Our basket contains just a single item, a Big Mac hamburger, but one that is sold around the world. The exchange rate that leaves a Big Mac costing the same in dollars everywhere is our fair-value yardstick.

Only a handful of currencies are close to their Big Mac Ppp. Of the seven currencies that make up the Federal Reserve's major-currency index, only one (the Australian dollar) is within $10 \%$ of its fair value. Most of the rest look expensive. The euro is overvalued by a massive $50 \%$. The British pound, Swedish krona, Swiss franc and Canadian dollar are also trading well above their burger benchmark. All are more overvalued against the dollar than a year ago. Only the Japanese yen, undervalued by $27 \%$, could be considered a snip.

The dollar still buys a lot of burger in the rest of Asia too. The Singapore dollar is undervalued by $18 \%$ and the South Korean won by $12 \%$. The currencies of less well-off Asian countries, such as Indonesia, Malaysia and Thailand, look even cheaper. China's currency is among the most undervalued, though a bit less so than a year ago.

The angrier type of China-basher might conclude that the yuan should revalue so that it is much closer to its burger standard. But care needs to be taken when drawing hard conclusions from fast-food prices. PPP measures show where currencies should end up in the long run. Prices vary with local costs, such as rents and wages, which are lower in poor countries, as well as with the price of ingredients that trade across borders. For this reason, PPP is a more reliable comparison for the currencies of economies with similar levels of income.

For all these caveats, more sophisticated analyses come to broadly similar conclusions to our own. John Lipsky, number two at the IMF, said this week that the euro is above the fund's medium-term valuation benchmark. China's currency is "substantially undervalued" in the IMF's view. The dollar is sandwiched in between. The big drop in the greenback's value since 2002 has left it "close to its medium-term equilibrium level," said Mr Lipsky.

If that judgment is right, the squalls stirred up by the credit crises have moved at least one currency-the world's reserve money-closer to fair value. Curiously the crunch has not shaken faith in two currencies favoured by yield-hungry investors: the Brazilian real and Turkish lira. These two stand out as emerging-market currencies that trade well above their Big Mac PPPS. Both countries have high interest rates. Turkey's central bank recently raised its benchmark rate to $16.75 \%$; Brazil's pushed its key rate up to $13 \%$ on July 23 rd. These rates offer juicy returns for those willing to bear the risks. Those searching for a value meal should look elsewhere.

Source: Derived from The Economist $26^{\text {th }}$ July 2008 and http://www.economist.com/. 
TABLE 3.1

IMPLIED PPP EXCHANGE RATES FOR 24 COUNTRIES, 1994 TO 2008

\begin{tabular}{|c|c|c|c|c|c|c|c|c|c|c|c|c|c|c|c|c|c|c|}
\hline \multirow[t]{2}{*}{ Country } & \multicolumn{15}{|c|}{ Year } & \multirow{2}{*}{ Mean } & \multirow{2}{*}{ SD } & \multirow{2}{*}{$\begin{array}{c}\mathrm{CV} \\
(\times 100)\end{array}$} \\
\hline & 1994 & 1995 & 1996 & 1997 & 1998 & 1999 & 2000 & 2001 & 2002 & 2003 & 2004 & 2005 & 2006 & 2007 & 2008 & & & \\
\hline Argentina & 1.57 & 1.29 & 1.27 & 1.03 & 0.98 & 1.03 & 1.00 & 0.98 & 1.00 & 1.51 & 1.50 & 1.55 & 2.26 & 2.42 & 3.08 & 1.50 & 0.63 & 41.8 \\
\hline Australia & 1.07 & 1.06 & 1.06 & 1.03 & 1.04 & 1.09 & 1.03 & 1.18 & 1.21 & 1.11 & 1.12 & 1.06 & 1.05 & 1.01 & 0.97 & 1.07 & 0.06 & 5.79 \\
\hline Brazil & 652 & 1.04 & 1.25 & 1.23 & 1.21 & 1.21 & 1.18 & 1.42 & 1.45 & 1.68 & 1.86 & 1.93 & 2.07 & 2.02 & 2.10 & 44.9 & 168 & 374 \\
\hline Britain & 0.79 & 0.75 & 0.76 & 0.75 & 0.72 & 0.78 & 0.76 & 0.78 & 0.80 & 0.73 & 0.65 & 0.61 & 0.63 & 0.58 & 0.64 & 0.72 & 0.07 & 10.1 \\
\hline Canada & 1.24 & 1.19 & 1.21 & 1.19 & 1.09 & 1.23 & 1.14 & 1.31 & 1.34 & 1.18 & 1.10 & 1.07 & 1.14 & 1.14 & 1.15 & 1.18 & 0.08 & 6.53 \\
\hline Chile & 412 & 410 & 403 & 496 & 488 & 518 & 502 & 496 & 562 & 517 & 483 & 490 & 503 & 459 & 434 & 478 & 45.8 & 9.57 \\
\hline China & 3.91 & 3.88 & 4.07 & 4.01 & 3.87 & 4.07 & 3.94 & 3.90 & 4.22 & 3.65 & 3.59 & 3.43 & 3.39 & 3.23 & 3.50 & 3.78 & 0.29 & 7.76 \\
\hline Czech Republic & 21.7 & 21.6 & 21.6 & 21.9 & 21.1 & 21.9 & 21.7 & 22.0 & 22.6 & 20.9 & 19.5 & 18.4 & 19.0 & 15.5 & 18.5 & 20.5 & 1.94 & 9.46 \\
\hline Denmark & 11.2 & 11.5 & 10.9 & 10.6 & 9.30 & 10.2 & 9.86 & 9.74 & 9.94 & 10.2 & 9.57 & 9.07 & 8.95 & 8.14 & 7.84 & 9.81 & 1.05 & 10.7 \\
\hline Euro Area & 1.09 & 1.08 & 1.07 & 1.03 & 0.96 & 1.04 & 1.02 & 1.01 & 1.07 & 1.00 & 0.94 & 0.95 & 0.95 & 0.90 & 0.94 & 1.00 & 0.06 & 6.00 \\
\hline Hong Kong & 4.00 & 4.10 & 4.20 & 4.09 & 3.98 & 4.20 & 4.06 & 4.21 & 4.50 & 4.24 & 4.14 & 3.92 & 3.87 & 3.52 & 3.73 & 4.05 & 0.23 & 5.76 \\
\hline Hungary & 73.5 & 82.3 & 90.7 & 112 & 101 & 123 & 135 & 157 & 184 & 181 & 183 & 173 & 181 & 176 & 188 & 143 & 42.1 & 29.5 \\
\hline Japan & 170 & 169 & 122 & 122 & 109 & 121 & 117 & 116 & 105 & 96.7 & 90.3 & 81.7 & 80.6 & 82.1 & 78.4 & 111 & 28.7 & 25.9 \\
\hline Malaysia & 1.64 & 1.62 & 1.59 & 1.60 & 1.68 & 1.86 & 1.80 & 1.78 & 2.02 & 1.86 & 1.74 & 1.72 & 1.77 & 1.61 & 1.54 & 1.72 & 0.13 & 7.56 \\
\hline Mexico & 3.52 & 4.70 & 6.31 & 6.16 & 6.99 & 8.19 & 8.33 & 8.62 & 8.80 & 8.49 & 8.28 & 9.15 & 9.36 & 8.50 & 8.96 & 7.62 & 1.73 & 22.7 \\
\hline New Zealand & 1.25 & 1.27 & 1.25 & 1.34 & 1.35 & 1.40 & 1.34 & 1.42 & 1.59 & 1.46 & 1.50 & 1.45 & 1.44 & 1.35 & 1.37 & 1.39 & 0.09 & 6.74 \\
\hline Poland & 13478 & 1.47 & 1.61 & 1.78 & 2.07 & 2.26 & 2.19 & 2.32 & 2.37 & 2.33 & 2.17 & 2.12 & 2.10 & 2.02 & 1.96 & 900 & 3480 & 386 \\
\hline Russia & 1261 & 3491 & 4025 & 4545 & 4688 & 13.8 & 15.7 & 13.8 & 15.7 & 15.1 & 14.5 & 13.7 & 15.5 & 15.2 & 16.5 & 1211 & 1902 & 157 \\
\hline Singapore & 1.30 & 1.27 & 1.29 & 1.24 & 1.17 & 1.32 & 1.28 & 1.30 & 1.33 & 1.22 & 1.14 & 1.18 & 1.16 & 1.16 & 1.11 & 1.23 & 0.07 & 5.86 \\
\hline South Korea & 1000 & 991 & 975 & 950 & 1016 & 1235 & 1195 & 1181 & 1245 & 1218 & 1103 & 817 & 807 & 850 & 896 & 1032 & 155 & 15.0 \\
\hline Sweden & 11.1 & 11.2 & 11.0 & 10.7 & 9.38 & 9.88 & 9.56 & 9.45 & 10.4 & 11.1 & 10.3 & 10.1 & 10.6 & 9.68 & 10.6 & 10.3 & 0.64 & 6.17 \\
\hline Switzerland & 2.48 & 2.54 & 2.50 & 2.44 & 2.31 & 2.43 & 2.35 & 2.48 & 2.53 & 2.33 & 2.17 & 2.06 & 2.03 & 1.85 & 1.82 & 2.29 & 0.24 & 10.7 \\
\hline Taiwan & 27.0 & 28.0 & 27.5 & 28.1 & 26.6 & 28.8 & 27.9 & 27.6 & 28.1 & 25.8 & 25.9 & 24.5 & 24.2 & 22.0 & 21.0 & 26.2 & 2.34 & 8.91 \\
\hline Thailand & 20.9 & 20.7 & 20.3 & 19.3 & 20.3 & 21.4 & 21.9 & 21.7 & 22.1 & 21.8 & 20.3 & 19.6 & 19.4 & 18.2 & 17.4 & 20.3 & 1.39 & 6.82 \\
\hline
\end{tabular}

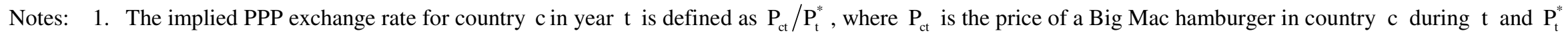
is the corresponding price in the US.

2. SD stands for standard deviation, and $\mathrm{CV}$ is the coefficient of variation.

Source: The Economist. 
TABLE 3.2

NOMINAL EXCHANGE RATES FOR 24 COUNTRIES, 1994 TO 2008

\begin{tabular}{|c|c|c|c|c|c|c|c|c|c|c|c|c|c|c|c|c|c|c|}
\hline \multirow[t]{2}{*}{ Country } & \multicolumn{15}{|c|}{ Year } & \multirow{2}{*}{ Mean } & \multirow{2}{*}{$\mathrm{SD}$} & \multirow{2}{*}{$\begin{array}{c}\mathrm{CV} \\
(\times 100)\end{array}$} \\
\hline & 1994 & 1995 & 1996 & 1997 & 1998 & 1999 & 2000 & 2001 & 2002 & 2003 & 2004 & 2005 & 2006 & 2007 & 2008 & & & \\
\hline Argentina & 1.00 & 1.00 & 1.00 & 1.00 & 1.00 & 1.00 & 1.00 & 1.00 & 3.13 & 2.88 & 2.94 & 2.89 & 3.06 & 3.09 & 3.02 & 1.93 & 1.04 & 53.6 \\
\hline Australia & 1.42 & 1.35 & 1.27 & 1.29 & 1.51 & 1.59 & 1.68 & 1.98 & 1.86 & 1.61 & 1.43 & 1.30 & 1.33 & 1.17 & 1.03 & 1.46 & 0.26 & 17.6 \\
\hline Brazil & 949 & 0.90 & 0.99 & 1.06 & 1.14 & 1.73 & 1.79 & 2.19 & 2.34 & 3.07 & 3.17 & 2.47 & 2.30 & 1.91 & 1.58 & 65.0 & 245 & 376 \\
\hline Britain & 0.69 & 0.62 & 0.66 & 0.61 & 0.60 & 0.62 & 0.63 & 0.70 & 0.69 & 0.63 & 0.56 & 0.55 & 0.53 & 0.50 & 0.50 & 0.61 & 0.07 & 10.9 \\
\hline Canada & 1.39 & 1.39 & 1.36 & 1.39 & 1.42 & 1.51 & 1.47 & 1.56 & 1.57 & 1.45 & 1.37 & 1.25 & 1.12 & 1.05 & 1.00 & 1.35 & 0.18 & 12.9 \\
\hline Chile & 414 & 395 & 408 & 417 & 455 & 484 & 514 & 601 & 655 & 716 & 643 & 593 & 530 & 527 & 494 & 523 & 99.9 & 19.1 \\
\hline China & 8.70 & 8.54 & 8.35 & 8.33 & 8.28 & 8.28 & 8.28 & 8.28 & 8.28 & 8.28 & 8.26 & 8.26 & 8.03 & 7.60 & 6.83 & 8.17 & 0.44 & 5.40 \\
\hline Czech Republic & 29.7 & 26.2 & 27.6 & 29.2 & 34.4 & 35.6 & 39.1 & 39.0 & 34.0 & 28.9 & 26.5 & 24.5 & 22.1 & 21.1 & 14.5 & 28.8 & 6.85 & 23.8 \\
\hline Denmark & 6.69 & 5.43 & 5.85 & 6.52 & 7.02 & 6.91 & 8.04 & 8.46 & 8.38 & 6.78 & 6.22 & 6.06 & 5.82 & 5.46 & 4.70 & 6.56 & 1.10 & 16.8 \\
\hline Euro Area & 0.88 & 0.74 & 0.79 & 0.87 & 0.93 & 0.93 & 1.08 & 1.14 & 1.12 & 0.91 & 0.83 & 0.81 & 0.78 & 0.74 & 0.63 & 0.88 & 0.15 & 16.5 \\
\hline Hong Kong & 7.73 & 7.73 & 7.74 & 7.75 & 7.75 & 7.75 & 7.79 & 7.80 & 7.80 & 7.80 & 7.80 & 7.79 & 7.75 & 7.82 & 7.80 & 7.77 & 0.03 & 0.39 \\
\hline Hungary & 103 & 121. & 150 & 178 & 213 & 237 & 279 & 303 & 272 & 224 & 211 & 204 & 206 & 180 & 144 & 202 & 57.6 & 28.6 \\
\hline Japan & 104 & 84.2 & 107 & 126 & 135 & 120 & 106 & 124 & 130 & 120 & 112 & 107 & 112 & 122 & 107 & 114 & 12.8 & 11.2 \\
\hline Malaysia & 2.69 & 2.49 & 2.49 & 2.50 & 3.72 & 3.80 & 3.80 & 3.80 & 3.80 & 3.80 & 3.79 & 3.81 & 3.63 & 3.43 & 3.20 & 3.38 & 0.55 & 16.4 \\
\hline Mexico & 3.36 & 6.37 & 7.37 & 7.90 & 8.54 & 9.54 & 9.41 & 9.29 & 9.28 & 10.5 & 11.5 & 10.9 & 11.3 & 10.8 & 10.2 & 9.09 & 2.16 & 23.8 \\
\hline New Zealand & 1.74 & 1.51 & 1.47 & 1.45 & 1.82 & 1.87 & 2.01 & 2.47 & 2.24 & 1.78 & 1.64 & 1.40 & 1.62 & 1.28 & 1.32 & 1.71 & 0.34 & 19.8 \\
\hline Poland & 22433 & 2.34 & 2.64 & 3.10 & 3.46 & 3.98 & 4.30 & 4.03 & 4.04 & 3.89 & 3.86 & 3.31 & 3.10 & 2.75 & 2.03 & 1499 & 5791 & 386 \\
\hline Russia & 1775 & 4985 & 4918 & 5739 & 5999 & 24.7 & 28.5 & 28.9 & 31.2 & 31.1 & 29.0 & 28.3 & 27.1 & 25.6 & 23.2 & 1580 & 2445 & 155 \\
\hline Singapore & 1.57 & 1.40 & 1.41 & 1.44 & 1.62 & 1.73 & 1.70 & 1.81 & 1.82 & 1.78 & 1.72 & 1.66 & 1.59 & 1.52 & 1.35 & 1.61 & 0.16 & 9.71 \\
\hline South Korea & 810 & 769 & 779 & 894 & 1474 & 1218 & 1108 & 1325 & 1304 & 1220 & 1176 & 1004 & 952 & 923 & 1018 & 1065 & 216 & 20.3 \\
\hline Sweden & 7.97 & 7.34 & 6.71 & 7.72 & 8.00 & 8.32 & 8.84 & 10.2 & 10.3 & 8.34 & 7.58 & 7.41 & 7.28 & 6.79 & 5.96 & 7.92 & 1.20 & 15.2 \\
\hline Switzerland & 1.44 & 1.13 & 1.23 & 1.47 & 1.52 & 1.48 & 1.70 & 1.73 & 1.66 & 1.37 & 1.28 & 1.25 & 1.21 & 1.21 & 1.02 & 1.38 & 0.21 & 15.5 \\
\hline Taiwan & 26.4 & 25.7 & 27.2 & 27.6 & 33.0 & 33.2 & 30.6 & 32.9 & 34.8 & 34.8 & 33.5 & 31.1 & 32.1 & 32.8 & 30.4 & 31.1 & 3.02 & 9.73 \\
\hline Thailand & 25.3 & 24.6 & 25.3 & 26.1 & 40.0 & 37.6 & 38.0 & 45.5 & 43.3 & 42.7 & 40.6 & 40.5 & 38.4 & 34.5 & 33.4 & 35.7 & 7.19 & 20.1 \\
\hline
\end{tabular}

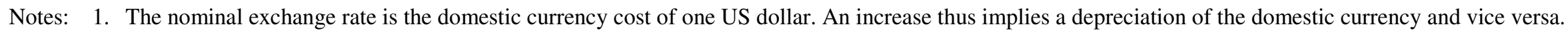

2. SD stands for standard deviation, and $\mathrm{CV}$ is the coefficient of variation.

Source: The Economist. 


\section{FIGURE 3.2}

THE VOLATILITY OF EXCHANGE RATES AND PRICES, 1994-2008

(Coefficients of variation; percentages)

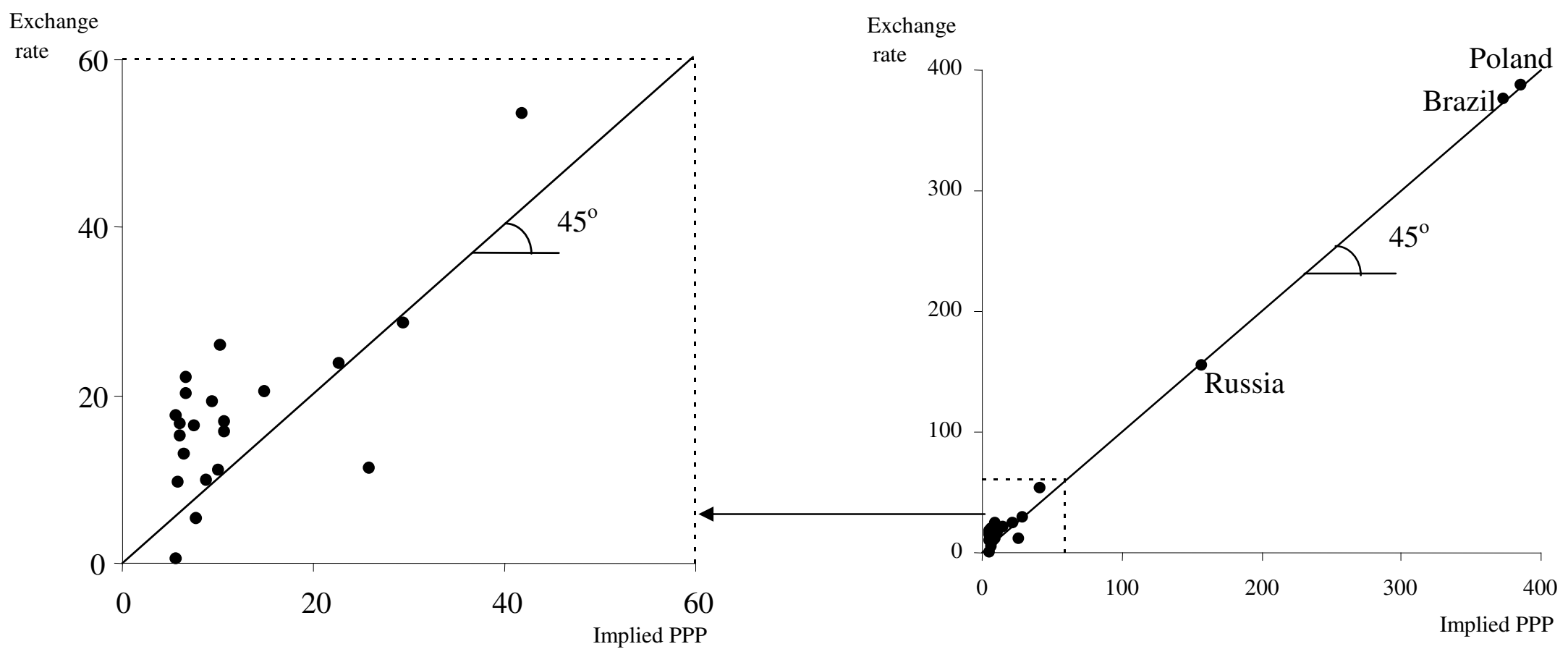


TABLE 3.3

REAL EXCHANGE RATES FOR 24 COUNTRIES, 1994 - 2008

\begin{tabular}{|c|c|c|c|c|c|c|c|c|c|c|c|c|c|c|c|c|c|c|}
\hline \multirow{2}{*}{ Country } & \multicolumn{15}{|c|}{ Year } & \multirow{2}{*}{ Mean } & \multirow{2}{*}{ SE } & \multirow{2}{*}{ t-value } \\
\hline & 1994 & 1995 & 1996 & 1997 & 1998 & 1999 & 2000 & 2001 & 2002 & 2003 & 2004 & 2005 & 2006 & 2007 & 2008 & & & \\
\hline Argentina & 44.80 & 25.70 & 24.00 & 3.25 & -2.37 & 2.84 & -0.40 & -1.59 & -113.7 & -64.38 & -67.27 & -62.37 & -30.39 & -24.47 & 2.01 & -17.62 & 11.05 & -1.60 \\
\hline Australia & -28.75 & -24.56 & -18.14 & -22.21 & -37.76 & -37.71 & -48.74 & -51.66 & -43.42 & -37.46 & -24.49 & -20.21 & -23.79 & -14.53 & -6.38 & -29.32 & 3.35 & -8.74 \\
\hline Brazil & -37.51 & 14.76 & 23.32 & 14.65 & 6.04 & -35.42 & -42.07 & -43.51 & -48.15 & -60.35 & -53.41 & -24.71 & -10.80 & 5.77 & 28.49 & -17.53 & 7.90 & -2.22 \\
\hline Britain & 13.89 & 18.86 & 13.57 & 19.81 & 17.66 & 23.02 & 17.90 & 11.36 & 14.74 & 14.86 & 15.02 & 11.62 & 16.26 & 15.96 & 24.91 & 16.63 & 0.99 & 16.76 \\
\hline Canada & -11.14 & -15.20 & -11.53 & -15.53 & -26.46 & -20.47 & -25.82 & -17.39 & -16.04 & -20.54 & -21.88 & -15.14 & 1.37 & 8.03 & 13.60 & -12.94 & 3.04 & -4.25 \\
\hline Chile & -0.44 & 3.60 & -1.35 & 17.32 & 7.06 & 6.79 & -2.36 & -19.19 & -15.27 & -32.64 & -28.54 & -19.02 & -5.18 & -13.83 & -12.91 & -7.73 & 3.62 & -2.14 \\
\hline China & -79.90 & -78.91 & -71.92 & -73.15 & -76.13 & -70.92 & -74.16 & -75.35 & -67.48 & -81.83 & -83.36 & -87.94 & -86.32 & -85.70 & -66.82 & -77.32 & 1.75 & -44.29 \\
\hline Czech Republic & -31.20 & -19.53 & -24.47 & -28.76 & -48.91 & -48.56 & -59.06 & -57.04 & -40.83 & -32.53 & -30.86 & -28.55 & -14.86 & -30.76 & 24.45 & -31.43 & 5.21 & -6.03 \\
\hline Denmark & 51.49 & 75.30 & 62.33 & 48.98 & 28.09 & 38.80 & 20.41 & 14.13 & 17.07 & 41.23 & 43.04 & 40.33 & 43.05 & 39.91 & 51.21 & 41.03 & 4.26 & 9.63 \\
\hline Euro Area & 21.39 & 37.17 & 30.17 & 16.77 & 3.50 & 11.33 & -5.28 & -11.61 & -4.67 & 9.53 & 12.31 & 15.65 & 19.39 & 19.92 & 40.61 & 14.41 & 3.87 & 3.72 \\
\hline Hong Kong & -65.88 & -63.54 & -61.25 & -63.89 & -66.53 & -61.32 & -65.07 & -61.60 & -55.05 & -60.87 & -63.29 & -68.66 & -69.42 & -79.85 & -73.89 & -65.34 & 1.54 & -42.55 \\
\hline Hungary & -33.77 & -38.51 & -50.33 & -46.34 & -74.45 & -65.55 & -72.55 & -65.69 & -38.90 & -21.42 & -14.05 & -16.29 & -13.13 & -2.27 & 26.28 & -35.13 & 7.40 & -4.74 \\
\hline Japan & 49.14 & 69.39 & 13.15 & -3.65 & -21.05 & 0.82 & 9.99 & -6.89 & -21.15 & -21.61 & -21.88 & -26.83 & -32.84 & -39.59 & -30.87 & -5.59 & 7.94 & -0.70 \\
\hline Malaysia & -49.54 & -42.94 & -44.65 & -44.68 & -79.51 & -71.44 & -74.68 & -75.87 & -62.99 & -71.45 & -77.95 & -79.63 & -71.59 & -75.45 & -73.10 & -66.36 & 3.54 & -18.74 \\
\hline Mexico & 4.70 & -30.44 & -15.47 & -24.93 & -20.00 & -15.27 & -12.23 & -7.46 & -5.37 & -21.57 & -33.23 & -17.06 & -18.89 & -23.90 & -12.92 & -16.94 & 2.52 & -6.73 \\
\hline New Zealand & -32.88 & -17.19 & -16.21 & -7.67 & -30.05 & -29.01 & -39.46 & -55.54 & -34.50 & -19.98 & -9.02 & 3.53 & -12.09 & 5.25 & 3.90 & -19.39 & 4.53 & -4.28 \\
\hline Poland & -50.95 & -46.79 & -49.44 & -55.66 & -51.36 & -56.44 & -67.41 & -55.10 & -53.36 & -51.48 & -57.61 & -44.55 & -39.10 & -30.68 & -3.47 & -47.56 & 3.83 & -12.41 \\
\hline Russia & -34.20 & -35.61 & -20.03 & -23.32 & -24.67 & -58.31 & -59.39 & -74.07 & -68.91 & -72.06 & -69.31 & -72.64 & -55.97 & -51.81 & -33.92 & -50.28 & 5.10 & -9.85 \\
\hline Singapore & -19.21 & -9.62 & -8.71 & -14.98 & -32.38 & -27.29 & -28.78 & -33.16 & -31.72 & -37.96 & -41.24 & -34.37 & -31.42 & -27.17 & -19.90 & -26.53 & 2.56 & -10.36 \\
\hline South Korea & 21.07 & 25.40 & 22.40 & 6.12 & -37.25 & 1.35 & 7.58 & -11.50 & -4.63 & -0.19 & -6.41 & -20.61 & -16.59 & -8.19 & -12.73 & -2.28 & 4.43 & -0.51 \\
\hline Sweden & 33.01 & 42.32 & 49.58 & 33.05 & 15.86 & 17.15 & 7.85 & -8.43 & 1.37 & 28.32 & 30.65 & 30.95 & 38.00 & 35.43 & 58.00 & 27.54 & 4.63 & 5.95 \\
\hline Switzerland & 54.29 & 81.12 & 70.93 & 50.59 & 41.62 & 49.50 & 32.40 & 36.03 & 42.14 & 52.88 & 52.45 & 50.10 & 51.85 & 42.32 & 57.94 & 51.08 & 3.23 & 15.84 \\
\hline Taiwan & 2.09 & 8.63 & 1.25 & 1.79 & -21.70 & -14.19 & -9.28 & -17.71 & -21.34 & -29.81 & -25.82 & -23.88 & -28.28 & -39.97 & -36.95 & -17.01 & 3.88 & -4.39 \\
\hline Thailand & -19.25 & -17.31 & -21.83 & -30.20 & -67.76 & -56.37 & -55.05 & -74.25 & -67.31 & -67.36 & -69.31 & -72.64 & -68.51 & -64.05 & -65.40 & -54.44 & 5.41 & -10.07 \\
\hline Mean & -8.28 & -1.58 & -4.36 & -10.11 & -24.94 & -21.53 & -26.90 & -31.80 & -30.81 & -27.44 & -26.89 & -24.29 & -19.14 & -18.32 & -4.91 & -18.75 & 2.75 & -5.95 \\
\hline SE & 7.83 & 8.73 & 7.64 & 6.79 & 7.04 & 7.28 & 7.03 & 6.64 & 7.01 & 7.53 & 7.73 & 7.66 & 7.40 & 7.49 & 8.22 & 6.75 & 1.97 & \\
\hline t-value & -1.06 & -0.18 & -0.57 & -1.49 & -3.54 & -2.96 & -3.83 & -4.79 & -4.39 & -3.65 & -3.48 & -3.17 & -2.58 & -2.44 & -0.60 & -2.78 & & -9.54 \\
\hline
\end{tabular}

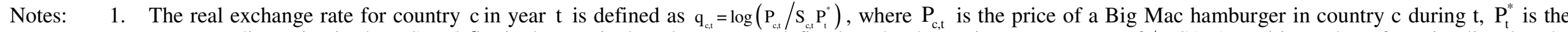
corresponding price in the US and $S_{c, t}$ is the nominal exchange rate, defined as the domestic currency cost of $\$ U S 1$. A positive value of $q_{c, t}$ implies that the domestic currency is overvalued in real terms and vice versa.

2. All entries, except those in the last row and column, are to be divided by 100 .

3. SE is standard error of the mean, which is a multiple $1 / \sqrt{\mathrm{k}}$ of the corresponding standard deviation, where $\mathrm{k}=15$ is the number of observations for the row means and $\mathrm{k}=24$ for the columns means. The t-values provide a test of the hypothesis that the means are zero.

4. The second to last entry in the second to last column, 2.75 , is the standard error of the grand average, calculated as the standard deviation of all $24 \times 15=360$ observations divided by $\sqrt{360}$. The corresponding t-value is presented in the right-bottom entry of the table. 


\section{FIGURE 3.3}

BIG MAC REAL EXCHANGE RATES FOR 24 COUNTRIES, 1994-2008

(Means indicated by dashed-dotted lines; two standard-error bands shaded; all × 100)
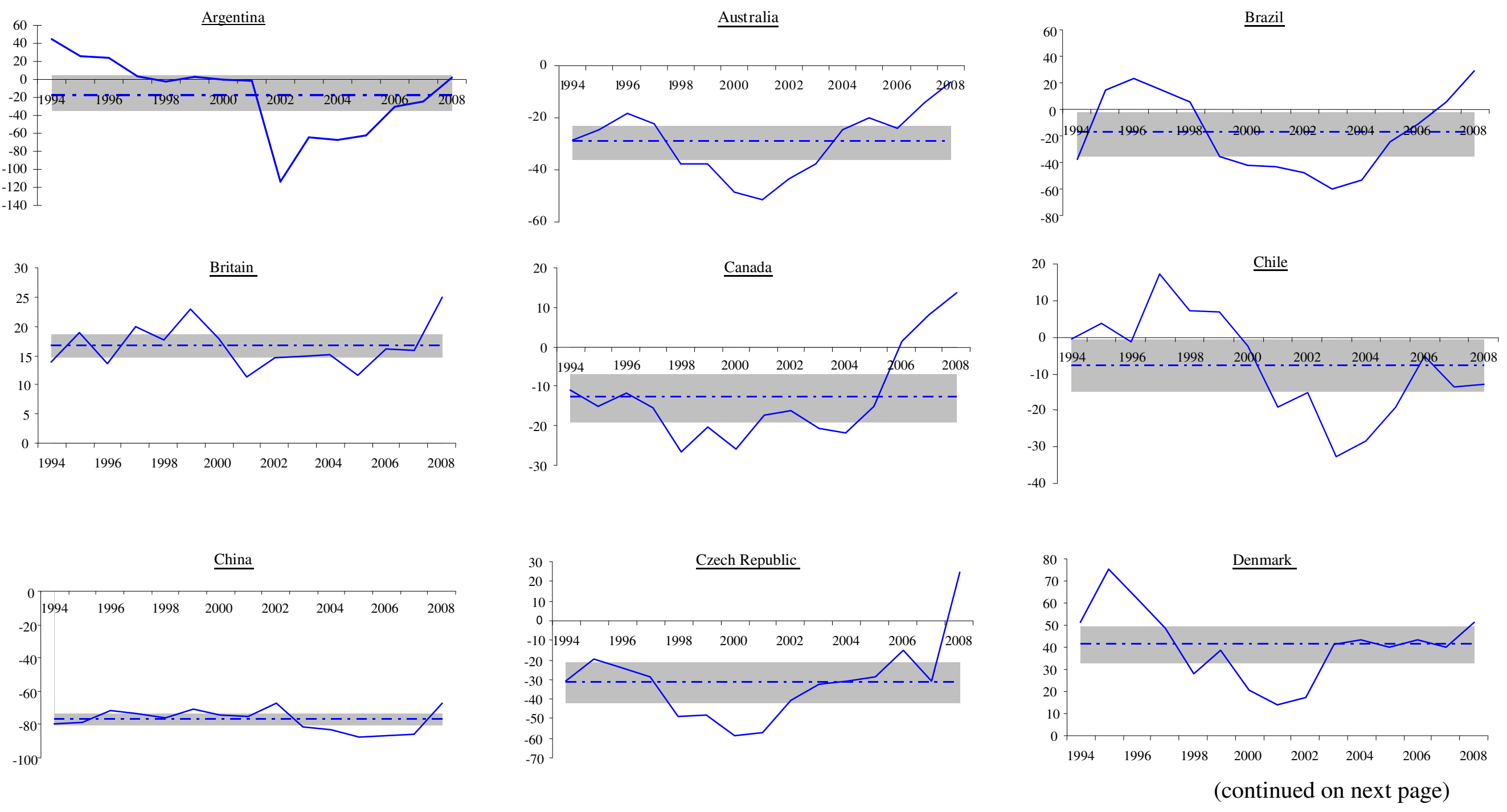
FIGURE 3.3 (continued)

BIG MAC REAL EXCHANGE RATES FOR 24 COUNTRIES, 1994-2008

(Means indicated by dashed-dotted lines; two standard-error bands shaded; all × 100)
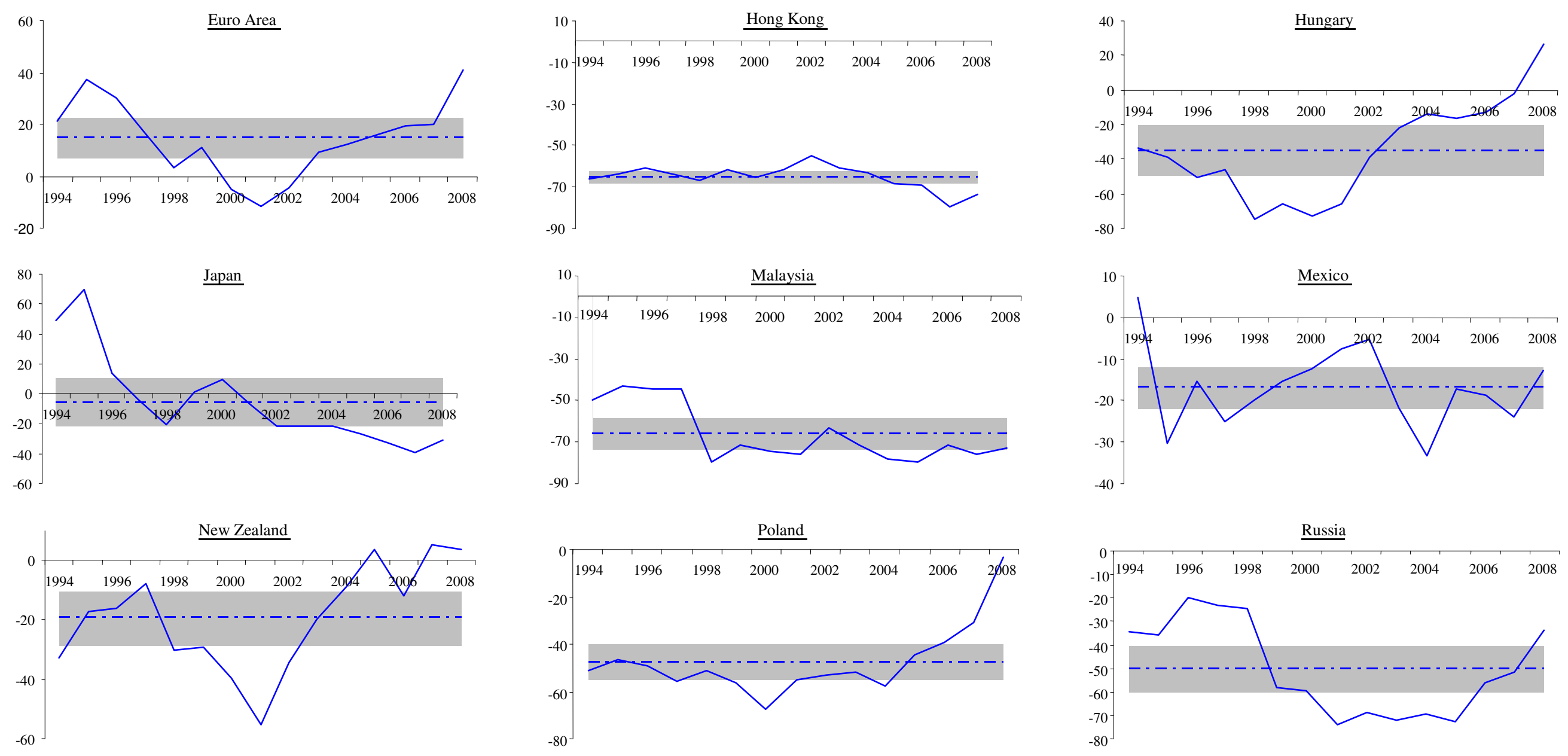

(continued on next page) 
FIGURE 3.3 (continued)

BIG MAC REAL EXCHANGE RATES FOR 24 COUNTRIES, 1994-2008

(Means indicated by dashed-dotted lines; two standard-error bands shaded; all × 100)
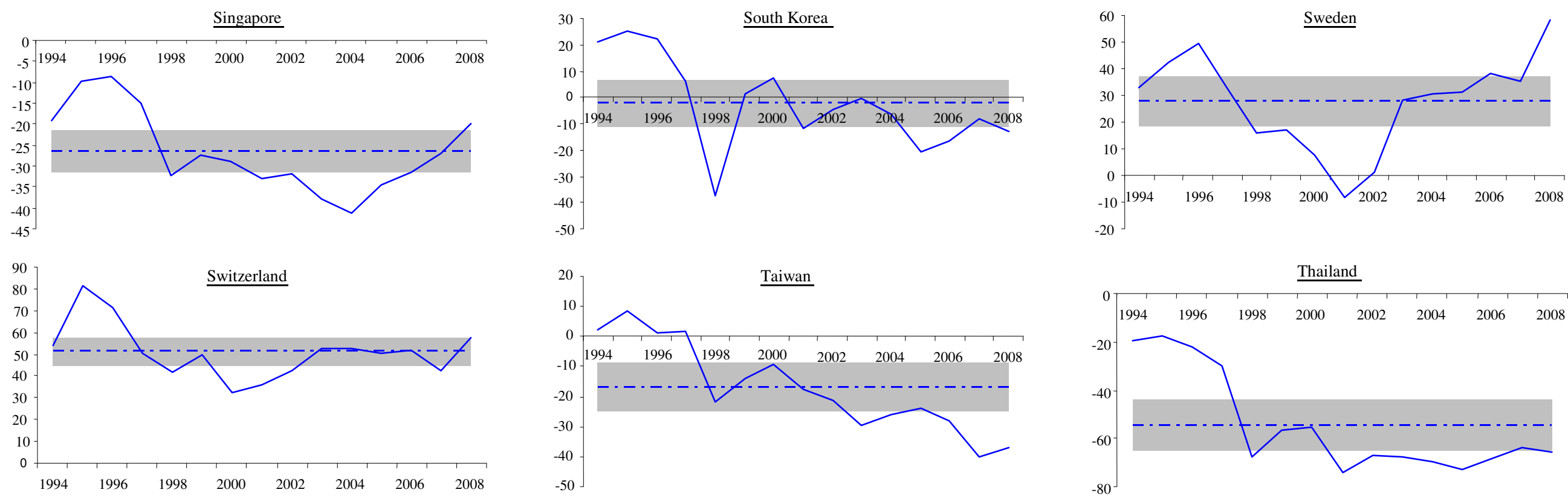
TABLE 3.4

CONTINGENCY TABLE TEST OF SERIAL INDEPENDENCE OF MISPRICING, ONE YEAR HORIZON

\begin{tabular}{|c|c|c|c|}
\hline \multirow{2}{*}{$\begin{array}{l}\text { Mispricing } \\
\text { in year } \mathrm{t}\end{array}$} & \multicolumn{2}{|c|}{ Mispricing in year $\mathrm{t}+1$} & \multirow{2}{*}{ Total } \\
\hline & Undervalued & Overvalued & \\
\hline \multicolumn{4}{|c|}{ I. Observed } \\
\hline \multirow{2}{*}{$\begin{array}{l}\text { Undervalued } \\
\text { Overvalued }\end{array}$} & 221 & 14 & 235 \\
\hline & 15 & 86 & 101 \\
\hline Total & 236 & 100 & 336 \\
\hline \multicolumn{4}{|c|}{ II. Expected under independence } \\
\hline \multirow{2}{*}{$\begin{array}{l}\text { Undervalued } \\
\text { Overvalued }\end{array}$} & 165 & 70 & 235 \\
\hline & 71 & 30 & 101 \\
\hline \multirow[t]{2}{*}{ Total } & 236 & 100 & 336 \\
\hline & III. Squared & leviations & \\
\hline \multirow{3}{*}{$\begin{array}{c}\text { Undervalued } \\
\text { Overvalued } \\
\text { Total }\end{array}$} & 19.0 & 44.7 & 63.7 \\
\hline & 44.1 & 104.1 & 148.2 \\
\hline & 63.1 & 148.8 & 211.9 \\
\hline
\end{tabular}

Note: The $(\mathrm{i}, \mathrm{j})^{\text {th }}$ element of Panel III is $\left(\mathrm{O}_{\mathrm{ij}}-\mathrm{E}_{\mathrm{ij}}\right)^{2} / \mathrm{E}_{\mathrm{ij}}$, where $\mathrm{O}_{\mathrm{ij}}$ and $\mathrm{E}_{\mathrm{ij}}$ are the corresponding observed and expected values.

TABLE 3.5

TESTS OF SERIAL INDEPENDENCE OVER VARIOUS HORIZONS

\begin{tabular}{ccc}
\hline \hline \multirow{2}{*}{$\begin{array}{c}\text { Horizon } \\
\text { Years })\end{array}$} & Observed $\chi^{2}$ value, with overlapping observations \\
\cline { 2 - 3 } & Included & Excluded \\
\hline 1 & 211.9 & 211.9 \\
2 & 162.1 & 81.3 \\
3 & 120.0 & 41.6 \\
4 & 93.0 & 24.1 \\
5 & 74.7 & 23.5 \\
6 & 52.1 & 18.0 \\
7 & 37.7 & 2.5 \\
8 & 33.7 & 6.7 \\
9 & 35.5 & 8.8 \\
10 & 26.3 & 8.8 \\
11 & 18.5 & 5.7 \\
12 & 13.1 & 5.7 \\
13 & 4.8 & 2.1 \\
14 & 1.4 & 1.4 \\
\hline
\end{tabular}

Notes: Under the null of independence, the test statistic follows a $\chi^{2}$ distribution with 1 degree of freedom. The critical value of $\chi_{.05}^{2}(1)$ is 3.8 and $\chi_{.01}^{2}(1)$ is 6.6. 
TABLE 3.6

RUNS TESTS FOR ABSOLUTE PARITY

\begin{tabular}{|c|c|c|c|c|c|}
\hline \multirow{2}{*}{ Country } & \multirow{2}{*}{$\begin{array}{l}\text { Sequence of signs } \\
\text { of disparities }\end{array}$} & \multicolumn{2}{|c|}{ Number of runs } & \multirow{2}{*}{$\begin{array}{l}\text { Standard deviation } \\
\sqrt{\operatorname{var} \mathrm{R}}\end{array}$} & \multirow{2}{*}{$\begin{array}{c}\text { Test } \\
\text { statistic Z }\end{array}$} \\
\hline & & Observed R & Expected E(R) & & \\
\hline Argentina & ++++-+--------+ & 5 & 8.20 & 1.79 & -1.79 \\
\hline Australia & --------------- & 1 & 1.00 & 0.00 & $+\infty$ \\
\hline Brazil & -++++---------++ & 4 & 8.20 & 1.79 & -2.35 \\
\hline Britain & +++++++++++++++ & 1 & 1.00 & 0.00 & $+\infty$ \\
\hline Canada & ------------+++ & 2 & 5.80 & 1.14 & -3.33 \\
\hline Chile & -+-+++---------- & 5 & 6.87 & 1.43 & -1.31 \\
\hline China & --------------- & 1 & 1.00 & 0.00 & $+\infty$ \\
\hline Czech Republic & --------------+ & 2 & 2.87 & 0.34 & -2.55 \\
\hline Denmark & +++++++++++++++ & 1 & 1.00 & 0.00 & $+\infty$ \\
\hline Euro Area & ++++++---++++++ & 3 & 5.80 & 1.14 & -2.45 \\
\hline Hong Kong & --------------- & 1 & 1.00 & 0.00 & $+\infty$ \\
\hline Hungary & ---------------++ & 2 & 2.87 & 0.34 & -2.55 \\
\hline Japan & +++--++--------- & 4 & 7.67 & 1.64 & -2.23 \\
\hline Malaysia & --------------- & 1 & 1.00 & 0.00 & $+\infty$ \\
\hline Mexico & +-------------- & 2 & 2.87 & 0.34 & -2.55 \\
\hline New Zealand & ------------++-++ & 4 & 5.80 & 1.14 & -1.58 \\
\hline Poland & ----------------- & 1 & 1.00 & 0.00 & $+\infty$ \\
\hline Russia & --------------- & 1 & 1.00 & 0.00 & $+\infty$ \\
\hline Singapore & --------------- & 1 & 1.00 & 0.00 & $+\infty$ \\
\hline South Korea & ++++-++--------- & 4 & 8.20 & 1.79 & -2.35 \\
\hline Sweden & +++++++-+++++++ & 3 & 2.87 & 0.34 & 0.39 \\
\hline Switzerland & ++++++++++++++++ & 1 & 1.00 & 0.00 & $+\infty$ \\
\hline Taiwan & ++++------------ & 2 & 6.87 & 1.43 & -3.41 \\
\hline Thailand & ----------------- & 1 & 1.00 & 0.00 & $+\infty$ \\
\hline
\end{tabular}


FIGURE 3.4

THE GEOGRAPHY OF MONEY

OVER/UNDER-VALUATION OF CURRENCIES, 1994-2008 AVERAGES

Mean Real Exchange Rate

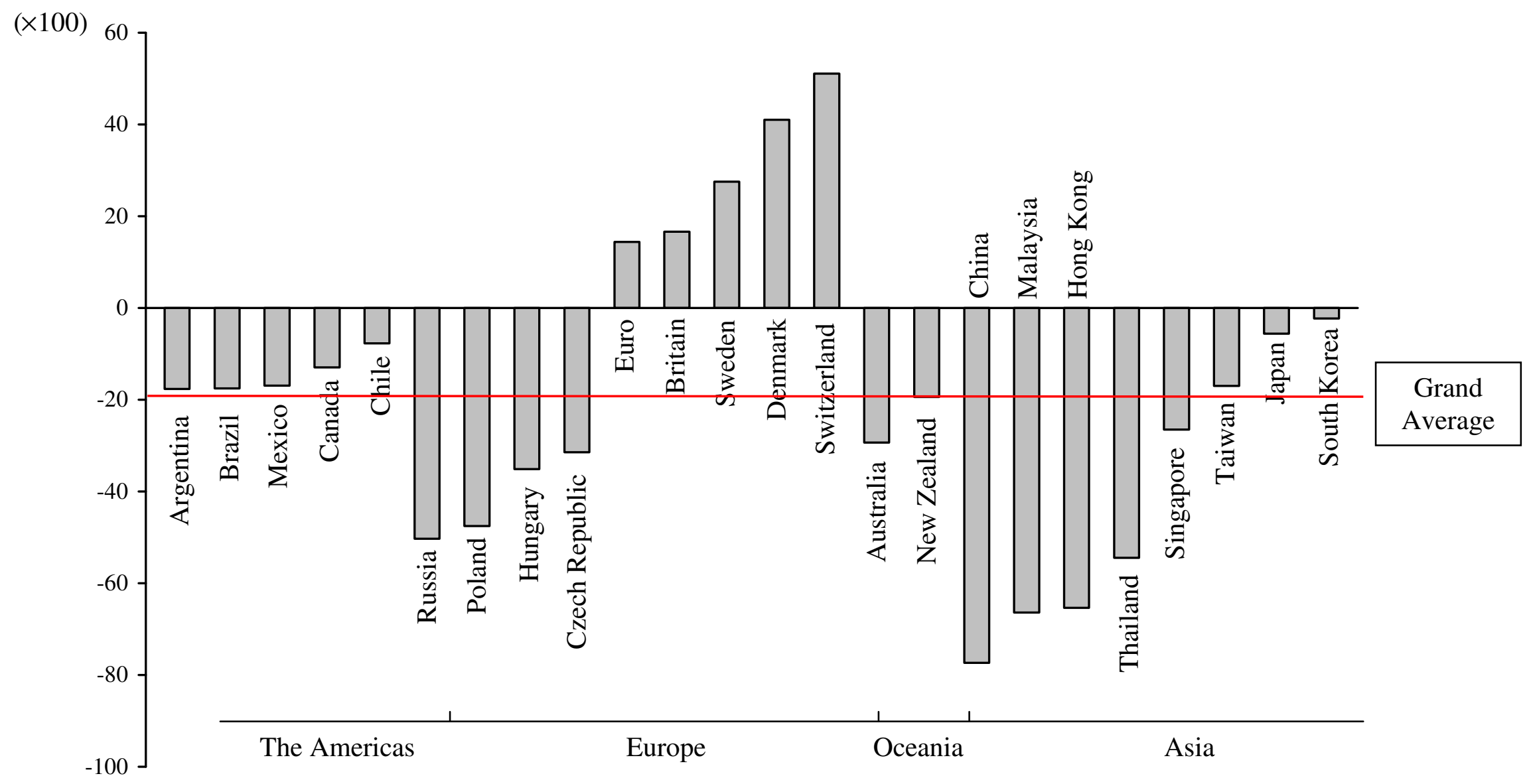


FIGURE 3.5

THE VALUE OF THE US DOLLAR, 1994-2008

(Mean indicated by dashed-dotted line; two standard error band shaded)

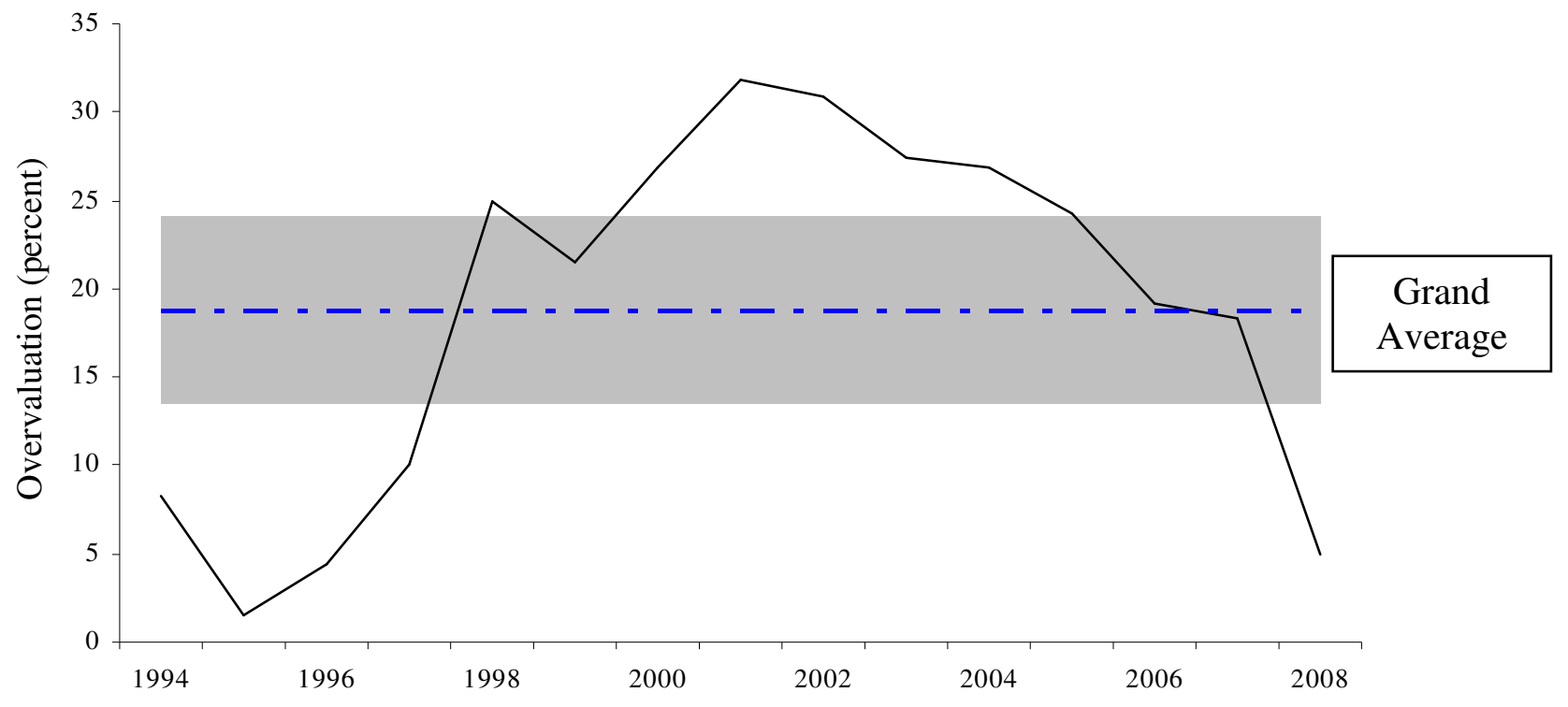


TABLE 3.7

MEAN REAL EXCHANGE RATES

(Logarithmic ratios $\times 100$; standard errors $\times 100$ in parentheses)

\begin{tabular}{|c|c|c|c|c|c|c|c|}
\hline \multirow{3}{*}{$\begin{array}{l}\text { Country } \\
(1) \\
\text { Argentina }\end{array}$} & \multicolumn{6}{|c|}{ Period } & \multirow{2}{*}{$\begin{array}{c}\text { t-value for equality } \\
\text { of means } \\
(5)\end{array}$} \\
\hline & \multicolumn{2}{|c|}{$\begin{array}{c}\text { 1994-1997 } \\
(2)\end{array}$} & \multicolumn{2}{|c|}{$\begin{array}{c}1998-2008 \\
(3)\end{array}$} & \multicolumn{2}{|c|}{$\begin{array}{c}1994-2008 \\
(4)\end{array}$} & \\
\hline & 24.44 & $(8.49)$ & -32.92 & $(11.72)$ & -17.62 & $(11.05)$ & 3.96 \\
\hline Australia & -23.41 & $(2.22)$ & -31.47 & $(4.38)$ & -29.32 & $(3.35)$ & 1.64 \\
\hline Brazil & 3.80 & (13.92) & -25.28 & $(8.69)$ & -17.53 & $(7.90)$ & 1.77 \\
\hline Britain & 16.53 & $(1.63)$ & 16.66 & $(1.26)$ & 16.63 & $(0.99)$ & -0.07 \\
\hline Canada & -13.35 & (1.17) & -12.79 & $(4.18)$ & -12.94 & (3.04) & -0.13 \\
\hline Chile & 4.78 & $(4.32)$ & -12.28 & $(3.90)$ & -7.73 & $(3.62)$ & 2.93 \\
\hline China & -75.97 & $(2.01)$ & -77.82 & $(2.30)$ & -77.33 & $(1.75)$ & 0.61 \\
\hline Czech Republic & -25.99 & $(2.56)$ & -33.41 & $(7.05)$ & -31.43 & $(5.21)$ & 0.99 \\
\hline Denmark & 59.53 & $(6.00)$ & 34.30 & $(3.71)$ & 41.03 & $(4.26)$ & 3.58 \\
\hline Euro Area & 26.38 & $(4.55)$ & 10.06 & (4.39) & 14.41 & (3.87) & 2.58 \\
\hline Hong Kong & -63.64 & $(0.95)$ & -65.96 & $(2.06)$ & -65.34 & (1.54) & 1.02 \\
\hline Hungary & -42.24 & $(3.74)$ & -32.55 & $(10.03)$ & -35.13 & $(7.40)$ & -0.91 \\
\hline Japan & 32.01 & (16.63) & -19.26 & $(4.49)$ & -5.59 & (7.94) & 2.98 \\
\hline Malaysia & -45.45 & $(1.42)$ & -73.97 & (1.43) & -66.37 & (3.54) & 14.15 \\
\hline Mexico & -16.53 & (7.72) & -17.08 & $(2.36)$ & -16.94 & $(2.52)$ & 0.07 \\
\hline New Zealand & -18.49 & $(5.25)$ & -19.72 & (6.01) & -19.39 & $(4.53)$ & 0.16 \\
\hline Poland & -50.71 & (1.86) & -46.41 & $(5.21)$ & -47.56 & (3.83) & -0.78 \\
\hline Russia & -28.29 & (3.89) & -58.28 & $(4.91)$ & -50.28 & $(5.10)$ & 4.79 \\
\hline Singapore & -13.13 & $(2.45)$ & -31.40 & $(1.72)$ & -26.53 & $(2.56)$ & 6.09 \\
\hline South Korea & 18.75 & $(4.31)$ & -9.92 & $(3.68)$ & -2.28 & (4.43) & 5.06 \\
\hline Sweden & 39.49 & (4.01) & 23.19 & (5.66) & 27.54 & (4.63) & 2.35 \\
\hline Switzerland & 64.23 & (7.16) & 46.30 & (2.39) & 51.08 & (3.23) & 2.38 \\
\hline Taiwan & 3.44 & (1.74) & -24.45 & $(2.76)$ & -17.01 & (3.88) & 8.54 \\
\hline Thailand & -22.15 & $(2.84)$ & -66.18 & $(1.79)$ & -54.44 & $(5.41)$ & 13.12 \\
\hline Mean & -6.08 & (1.89) & -23.36 & (2.99) & -18.75 & (3.48) & 4.48 \\
\hline
\end{tabular}




\section{FIGURE 4.1}

\section{SCATTER PLOTS OF EXCHANGE RATES AND PRICES,}

24 COUNTRIES, 1994-2008

(Annualised logarithmic changes $\times 100$ )
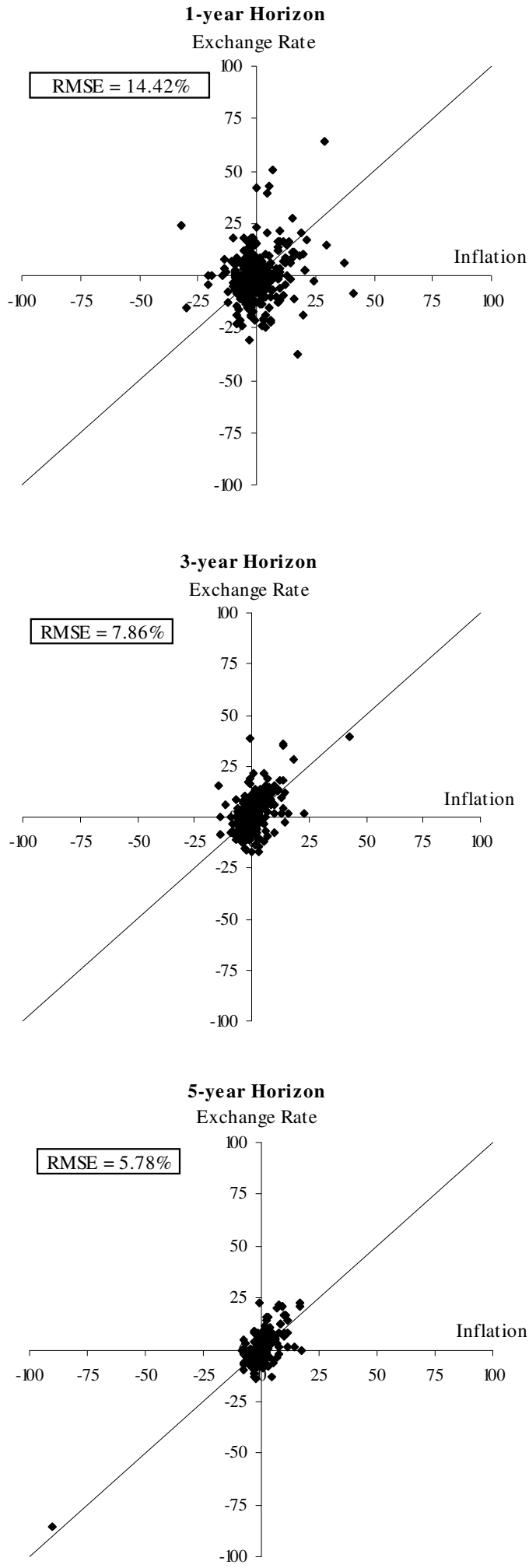
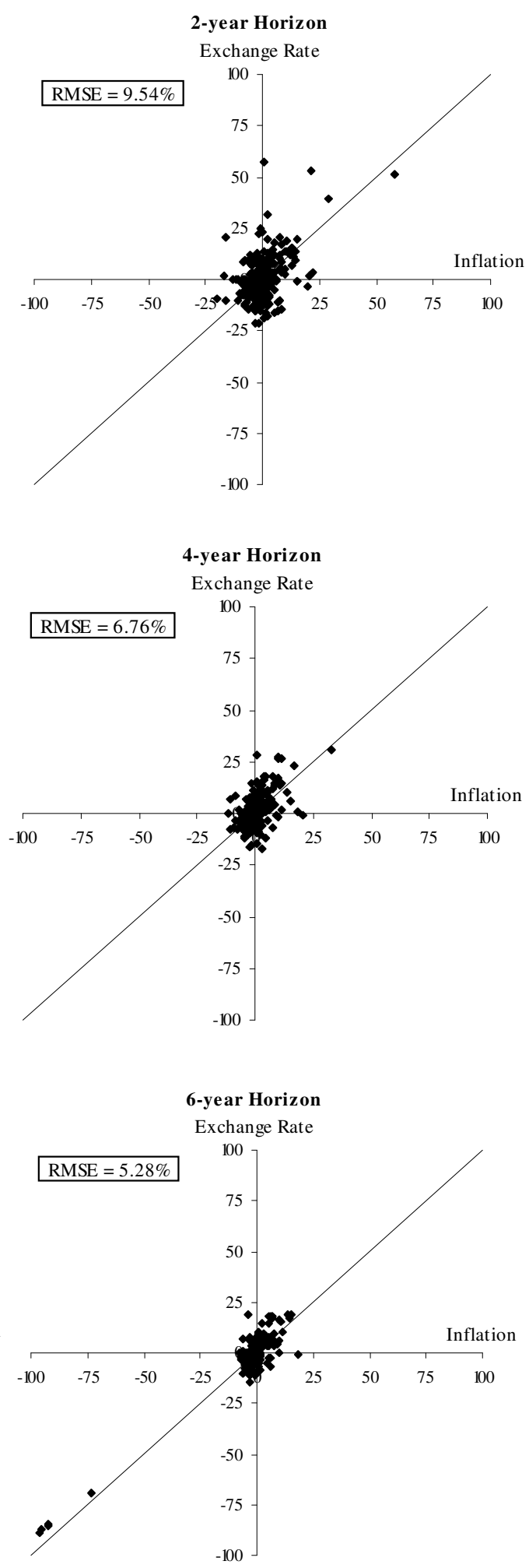

(continued on next page) 
FIGURE 4.1 (continued)

\section{SCATTER PLOTS OF EXCHANGE RATES AND PRICES, 24 COUNTRIES, 1994-2008}

(Annualised logarithmic changes $\times 100$ )
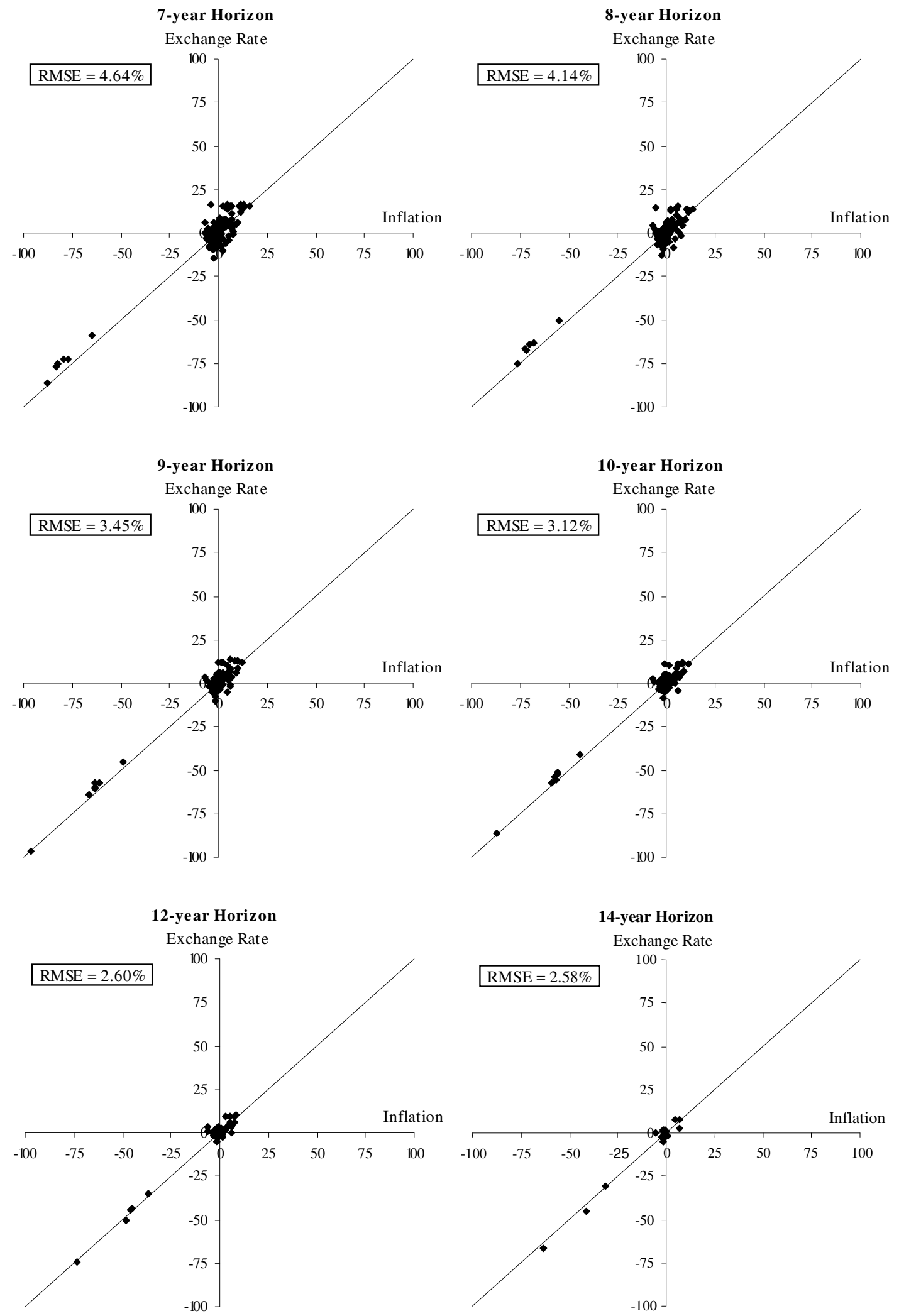

Note: To facilitate presentation, the cases in which the annualised logarithmic changes $(\times 100)$ exceeded $100 \%$ have been omitted. These cases are included in the computation of the RMSEs. 
FIGURE 4.2

\section{BLOW-UP OF SCATTER PLOTS OF EXCHANGE RATES AND PRICES,} 24 COUNTRIES, 1994-2008

(Annualised logarithmic changes $\times 100$ )
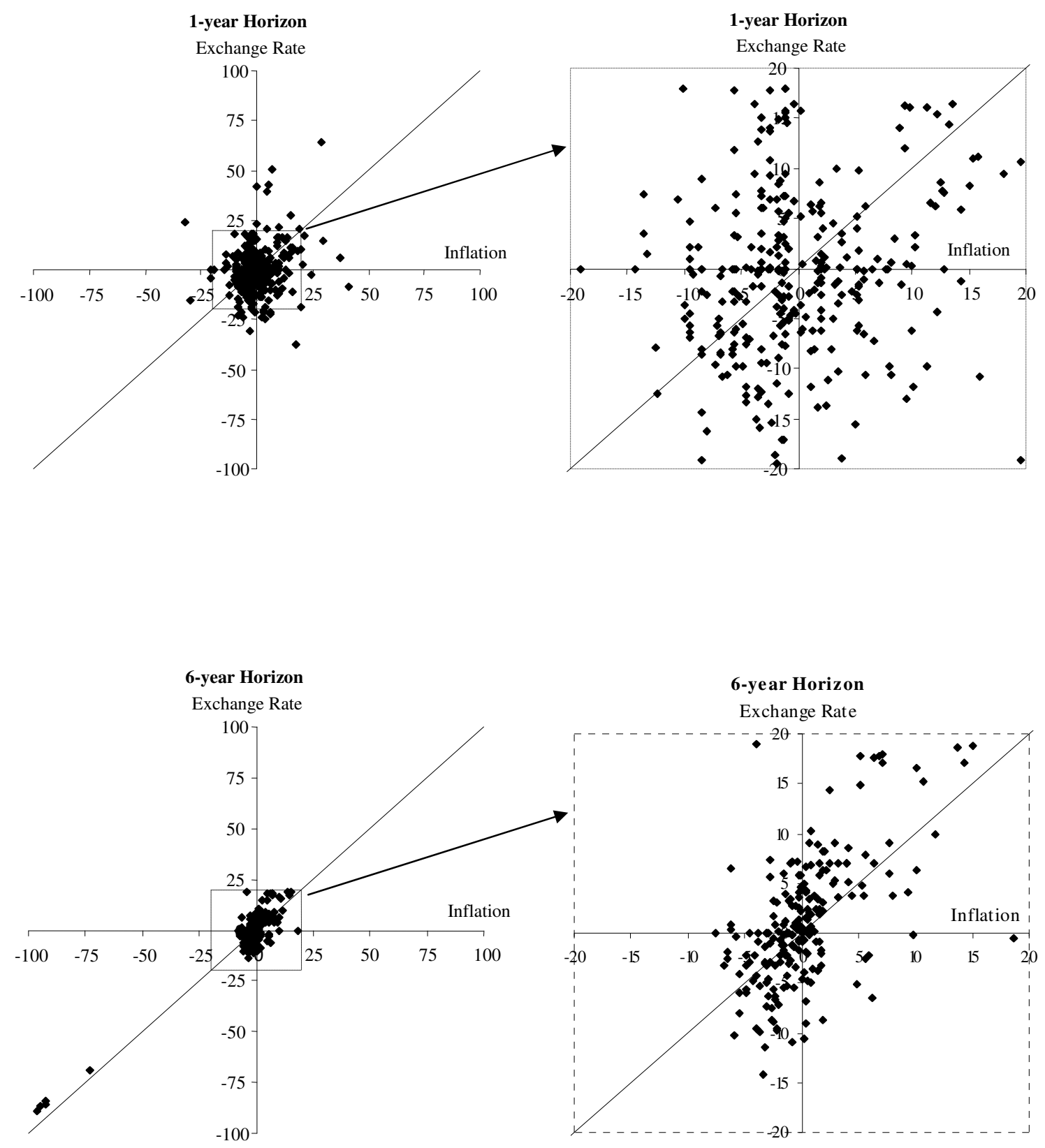

(continued on next page) 
FIGURE 4.2 (continued)

BLOW-UP OF SCATTER PLOTS OF EXCHANGE RATES AND PRICES, FOR 24 COUNTRIES, 1994-2008

(Annualised logarithmic changes $\times 100$ )

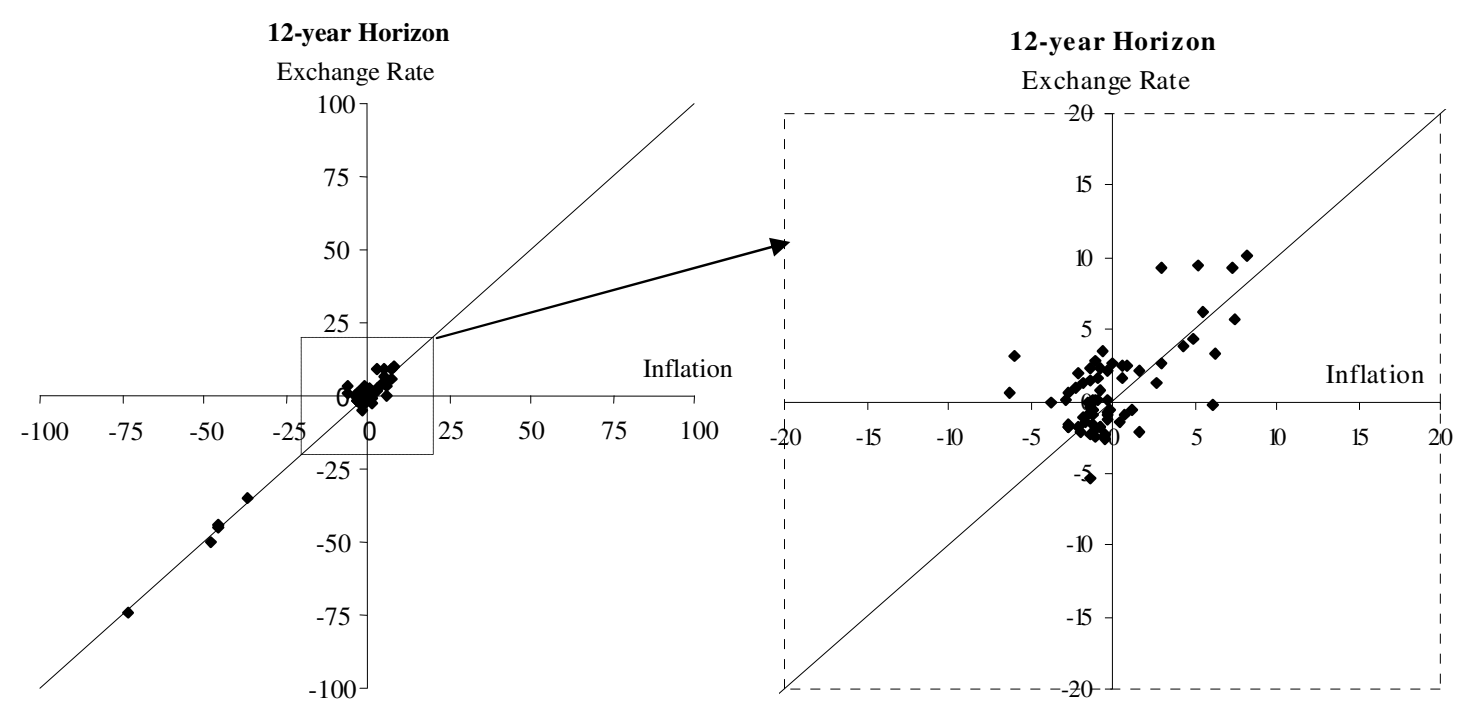

Note: To facilitate presentation, the cases in which the annualised logarithmic changes $(\times 100)$ exceeded $20 \%$ have been omitted. These cases are included in the computation of the RMSEs. 
FIGURE 4.3

\section{VARIANCES OF EXCHANGE RATE CHANGES}
A. Annualised changes
B. Total changes
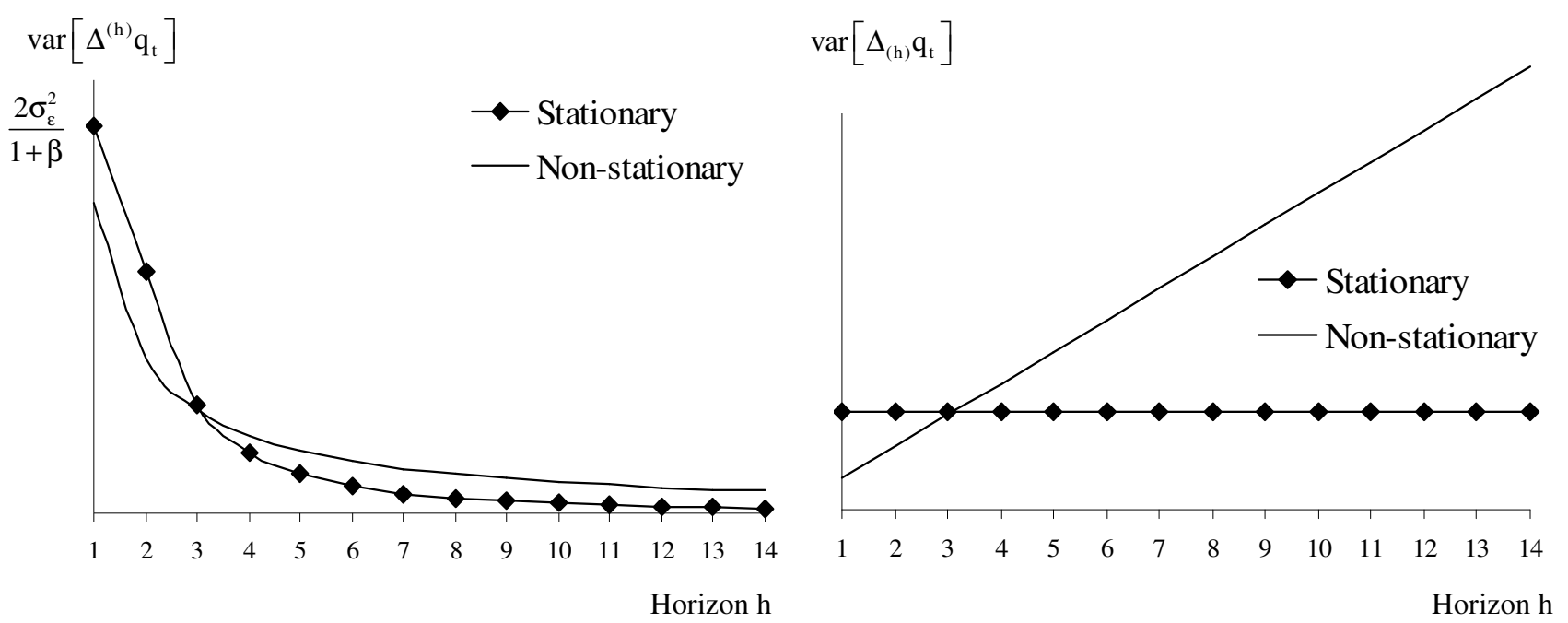

FIGURE 4.4

TOTAL VOLATILITY AND THE HORIZON

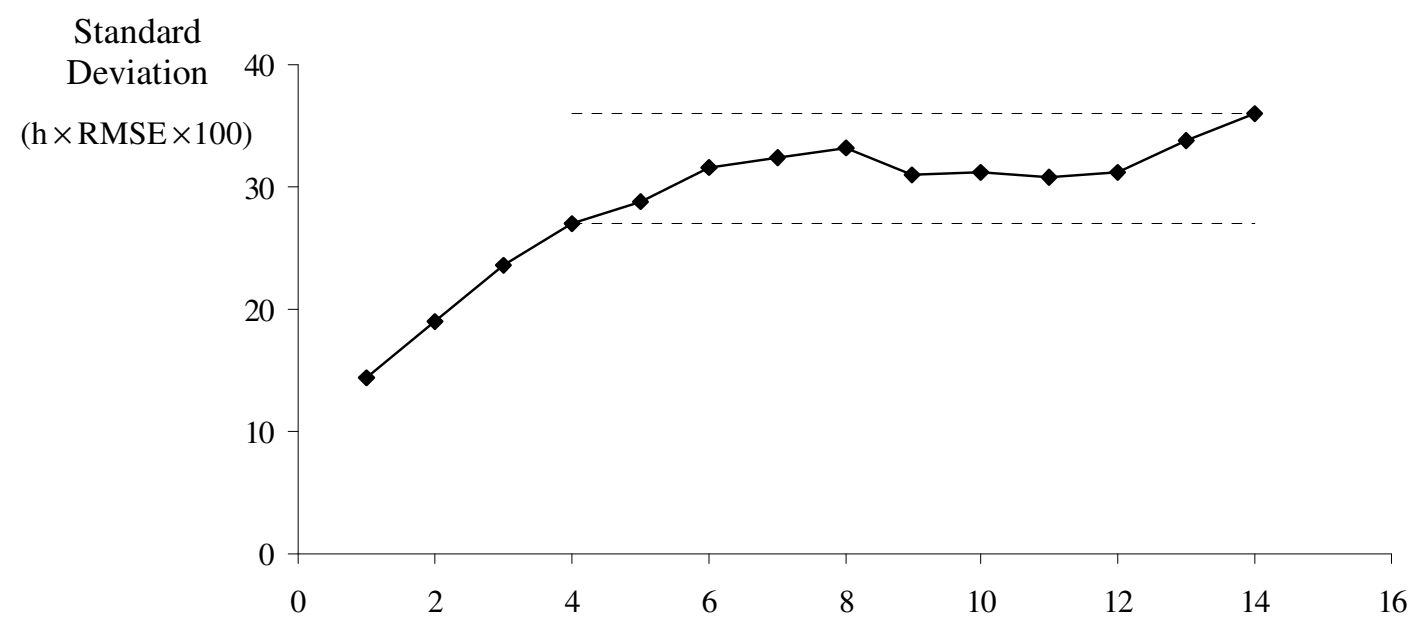

Horizon h

(years) 
FIGURE 5.1

SCATTER PLOTS OF FUTURE REAL EXCHANGE RATES AGAINST

CURRENT DEVIATIONS FROM PARITY, 24 COUNTRIES, 1994-2008

(Logarithmic changes $\times 100$ )
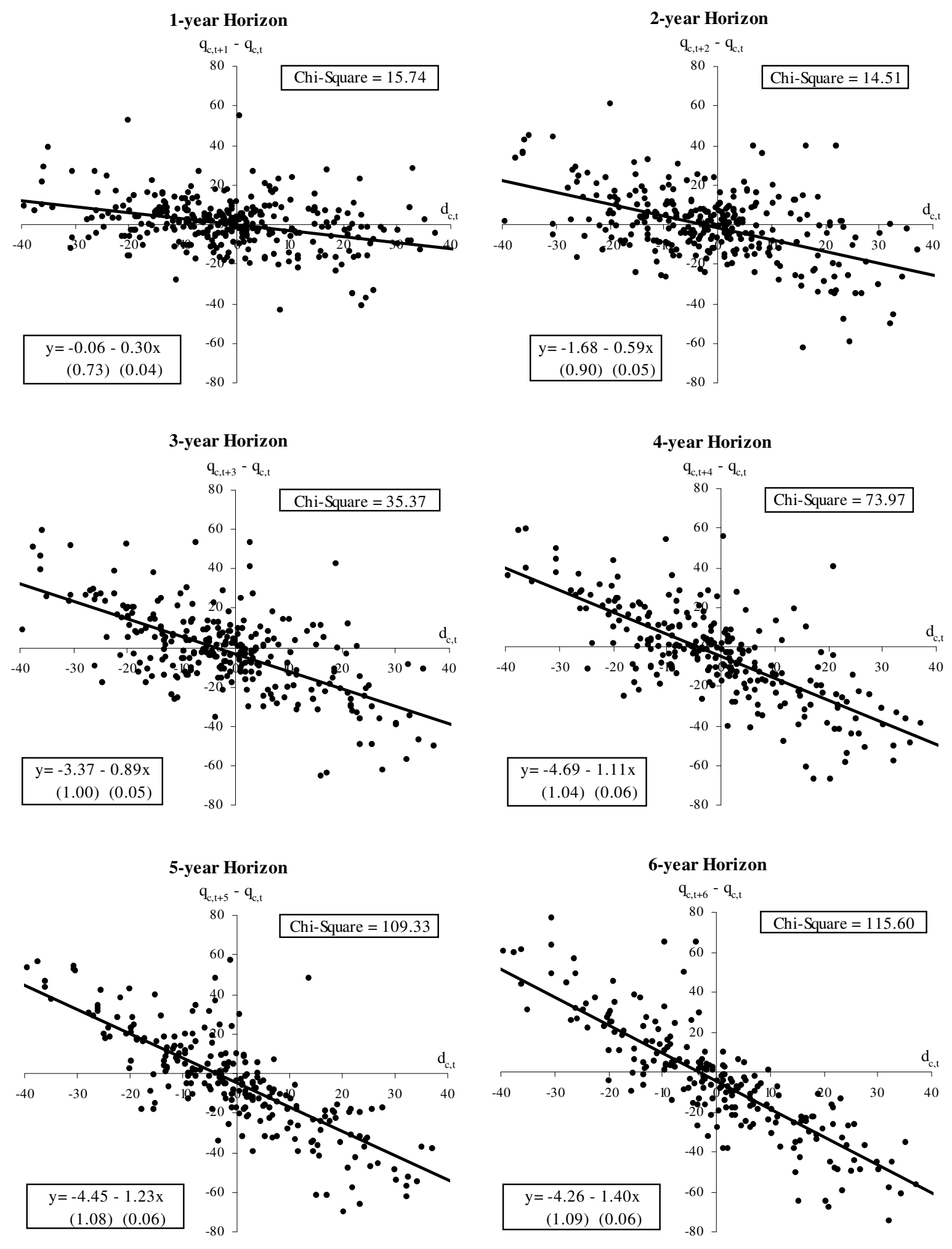

(continued on next page) 
FIGURE 5.1 (continued)

SCATTER PLOTS OF FUTURE REAL EXCHANGE RATES AGAINST

CURRENT DEVIATIONS FROM PARITY, 24 COUNTRIES, 1994-2008

(Logarithmic changes $\times 100$ )
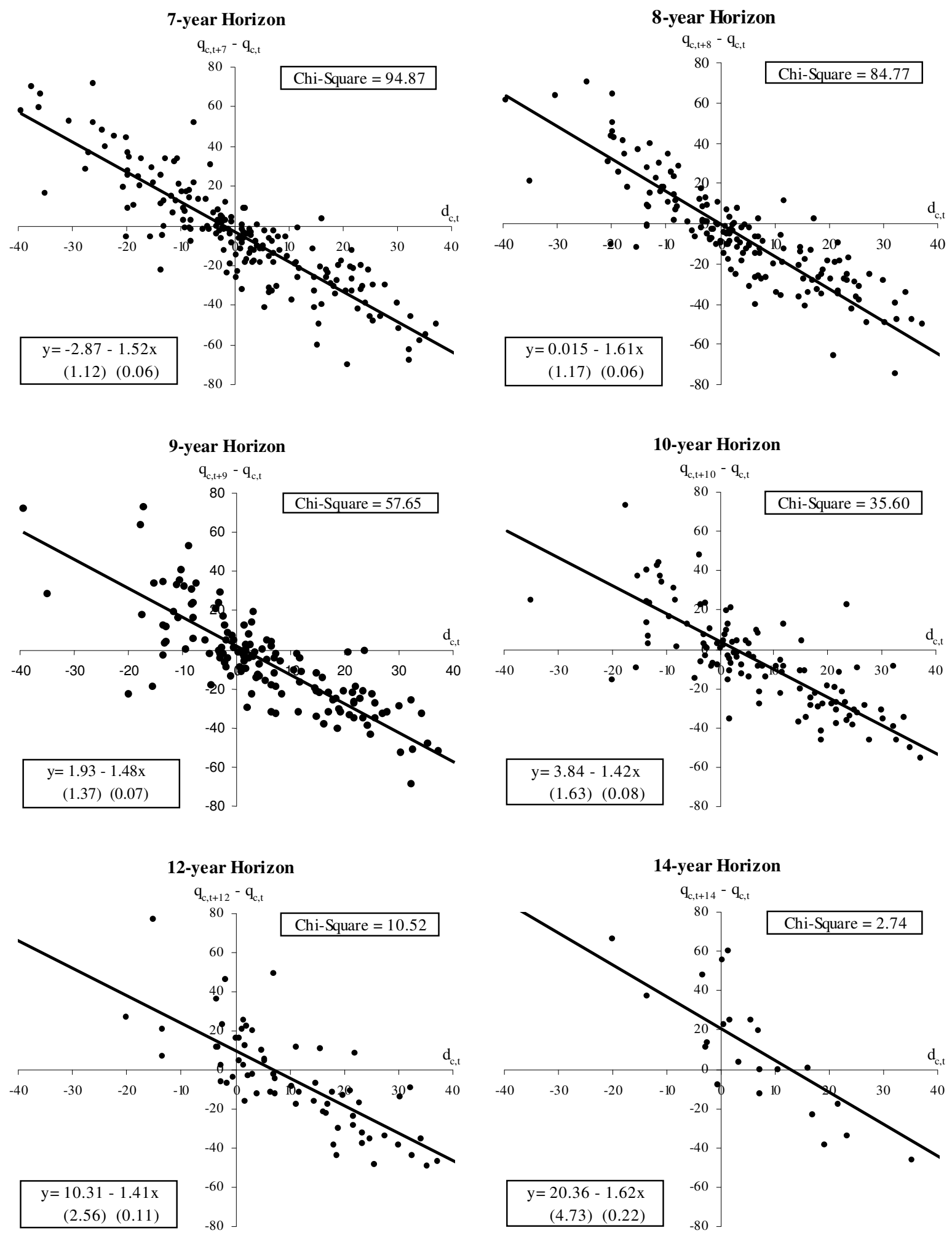

Note: To facilitate presentation, the cases in which the annualised logarithmic changes $(\times 100)$ exceeded $80 \%$ have been omitted. These cases are included in the regression and the chi square value. 
FIGURE 5.2

\section{PREDICTIVE VALUE OF DEVIATIONS FROM PARITY: CHI SQUARE VALUE AGAINST HORIZON}

Chi square value

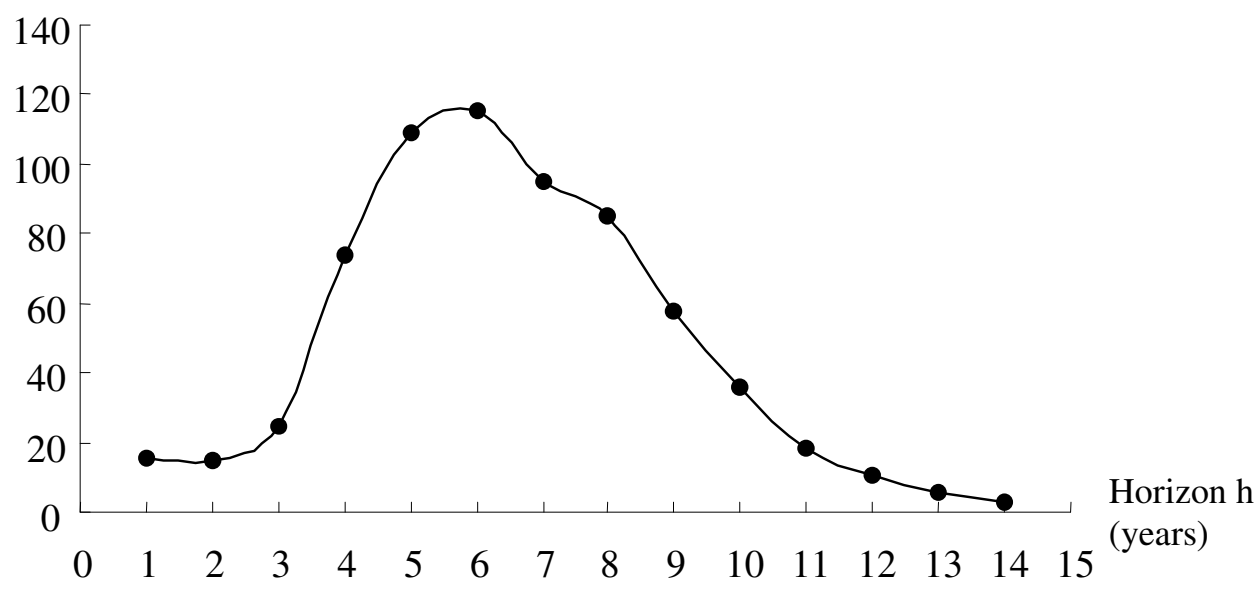


TABLE 5.1

PREDICTIVE REGRESSIONS, REAL EXCHANGE RATES, 24 COUNTRIES, 1994-2008

$\mathrm{q}_{\mathrm{c}, \mathrm{th}}-\mathrm{q}_{\mathrm{c}, \mathrm{t}}=\eta^{\mathrm{h}}+\phi^{\mathrm{h}} \mathrm{d}_{\mathrm{c}, \mathrm{t}}+\mathrm{u}_{\mathrm{c}, \mathrm{t}}^{\mathrm{h}} \quad$ (Standard errors in parentheses)

\begin{tabular}{|c|c|c|c|c|c|c|c|c|c|c|c|c|}
\hline \multirow[b]{2}{*}{$\begin{array}{c}\text { Horizon } \\
\text { h } \\
\text { (1) }\end{array}$} & \multicolumn{6}{|c|}{ A. With overlapping observations } & \multicolumn{6}{|c|}{ B. Without overlapping observations } \\
\hline & $\begin{array}{l}\text { Intercept } \\
\eta^{\mathrm{h}} \times 100 \\
\quad(2)\end{array}$ & $\begin{array}{l}\text { Slope } \\
\phi^{\mathrm{h}} \\
(3)\end{array}$ & $\begin{array}{c}\text { No. of } \\
\text { observations } \\
\text { (4) }\end{array}$ & (5) & (6) & (7) & $\begin{array}{c}\text { Intercept } \\
\eta^{\mathrm{h}} \times 100 \\
\quad(8)\end{array}$ & $\begin{array}{l}\text { Slope } \\
\phi^{\text {h }} \\
(9)\end{array}$ & $\begin{array}{c}\text { No. of } \\
\text { observations } \\
\text { (10) }\end{array}$ & (11) & (12) & (13) \\
\hline 1 & $-0.06(0.73)$ & $\begin{array}{ll}-0.30(0.04) \\
-0.30(0.04)\end{array}$ & $\begin{array}{l}336 \\
336\end{array}$ & 0.14 & 15.74 & $143.39 *$ & $-0.06(0.73)$ & $\begin{array}{l}-0.30(0.04) \\
-0.30(0.04)\end{array}$ & $\begin{array}{l}336 \\
336\end{array}$ & 0.14 & 15.74 & $143.39 *$ \\
\hline 2 & $-1.68(0.90)$ & $\begin{array}{l}-0.59(0.05) \\
-0.59(0.05)\end{array}$ & $\begin{array}{l}312 \\
312\end{array}$ & 0.31 & 14.51 & $35.67 *$ & $-0.36(1.38)$ & $\begin{array}{l}-0.59(0.08) \\
-0.58(0.08)\end{array}$ & $\begin{array}{l}168 \\
168\end{array}$ & 0.27 & 6.65 & $15.54 *$ \\
\hline 3 & $-3.37(1.00)$ & $\begin{array}{l}-0.89(0.05) \\
-0.88(0.06)\end{array}$ & $\begin{array}{l}288 \\
288\end{array}$ & 0.48 & 35.37 & $8.29 *$ & $-2.22(1.49)$ & $\begin{array}{l}-0.87(0.09) \\
-0.88(0.09)\end{array}$ & $\begin{array}{l}96 \\
96\end{array}$ & 0.52 & 19.84 & 2.17 \\
\hline 4 & $-4.69(1.04)$ & $\begin{array}{l}-1.11(0.06) \\
-1.10(0.06)\end{array}$ & $\begin{array}{l}264 \\
264\end{array}$ & 0.60 & 73.97 & $11.86^{*}$ & $-6.46(2.00)$ & $\begin{array}{l}-1.10(0.10) \\
-1.06(0.10)\end{array}$ & $\begin{array}{l}72 \\
72\end{array}$ & 0.65 & 24.50 & $5.42 *$ \\
\hline 5 & $-4.46(1.08)$ & $\begin{array}{l}-1.23(0.06) \\
-1.23(0.06)\end{array}$ & $\begin{array}{c}240 \\
24\end{array}$ & 0.66 & 109.33 & $16.63 *$ & $-5.94(1.93)$ & $\begin{array}{l}-0.88(0.11) \\
-0.96(0.12)\end{array}$ & $\begin{array}{l}48 \\
48\end{array}$ & 0.56 & 19.37 & $4.83^{*}$ \\
\hline 6 & $-4.26(1.09)$ & $\begin{array}{l}-1.40(0.06) \\
-1.41(0.06)\end{array}$ & $\begin{array}{l}216 \\
216\end{array}$ & 0.74 & 115.60 & $33.48^{*}$ & $-4.23(1.98)$ & $\begin{array}{l}-1.04(0.10) \\
-1.05(0.11)\end{array}$ & $\begin{array}{l}48 \\
48\end{array}$ & 0.69 & 30.86 & 2.40 \\
\hline 7 & $-2.87(1.12)$ & $\begin{array}{l}-1.52(0.06) \\
-1.54(0.06)\end{array}$ & $\begin{array}{l}192 \\
192\end{array}$ & 0.77 & 94.87 & $43.46^{*}$ & $-0.14(3.17)$ & $\begin{array}{l}-1.42(0.16) \\
-1.42(0.15)\end{array}$ & $\begin{array}{l}48 \\
48\end{array}$ & 0.64 & 19.86 & $3.65^{*}$ \\
\hline 8 & $0.02(1.17)$ & $\begin{array}{l}-1.62(0.06) \\
-1.61(0.06)\end{array}$ & $\begin{array}{l}168 \\
168\end{array}$ & 0.80 & 84.77 & $50.14 *$ & $-6.71(4.46)$ & $\begin{array}{l}-1.51(0.21) \\
-1.67(0.19)\end{array}$ & $\begin{array}{l}24 \\
24\end{array}$ & 0.70 & 10.29 & $7.80 *$ \\
\hline 9 & $1.94(1.37)$ & $\begin{array}{l}-1.48(0.07) \\
-1.44(0.07)\end{array}$ & $\begin{array}{l}144 \\
144\end{array}$ & 0.74 & 57.65 & $22.20 *$ & $-5.94(3.12)$ & $\begin{array}{l}-1.26(0.15) \\
-1.34(0.13)\end{array}$ & $\begin{array}{l}24 \\
24\end{array}$ & 0.77 & 6.40 & $6.75^{*}$ \\
\hline 10 & $3.84(1.63)$ & $\begin{array}{l}-1.43(0.08) \\
-1.34(0.08)\end{array}$ & $\begin{array}{l}120 \\
120\end{array}$ & 0.72 & 35.60 & $13.54^{*}$ & $-4.16(3.06)$ & $\begin{array}{l}-1.38(0.14) \\
-1.48(0.13)\end{array}$ & $\begin{array}{l}24 \\
24\end{array}$ & 0.81 & 2.67 & $8.17 *$ \\
\hline 11 & $8.02(2.08)$ & $\begin{array}{l}-1.47(0.10) \\
-1.23(0.09)\end{array}$ & $\begin{array}{l}96 \\
96\end{array}$ & 0.70 & 18.50 & $11.67 *$ & $0.22(2.22)$ & $\begin{array}{l}-1.55(0.10) \\
-1.54(0.09)\end{array}$ & $\begin{array}{l}24 \\
24\end{array}$ & 0.91 & 2.67 & $18.01 *$ \\
\hline 12 & $10.31(2.56)$ & $\begin{array}{l}-1.41(0.11) \\
-1.12(0.01)\end{array}$ & $\begin{array}{l}72 \\
72\end{array}$ & 0.68 & 10.52 & $8.96^{*}$ & $4.05(1.89)$ & $\begin{array}{l}-1.42(0.09) \\
-1.33(0.08)\end{array}$ & $\begin{array}{l}24 \\
24\end{array}$ & 0.92 & 2.90 & $11.55^{*}$ \\
\hline 13 & $13.07(3.40)$ & $\begin{array}{l}-1.43(0.14) \\
-1.10(0.13)\end{array}$ & $\begin{array}{l}48 \\
48\end{array}$ & 0.68 & 5.94 & $7.77 *$ & $5.94(2.89)$ & $\begin{array}{l}-1.53(0.14) \\
-1.39(0.13)\end{array}$ & $\begin{array}{l}24 \\
24\end{array}$ & 0.85 & 2.90 & $7.58^{*}$ \\
\hline 14 & $20.37(4.73)$ & $\begin{array}{l}-1.62(0.22) \\
-1.16(0.26)\end{array}$ & $\begin{array}{l}24 \\
24\end{array}$ & 0.71 & 2.74 & $9.61 *$ & $20.37(4.73)$ & $\begin{array}{l}-1.62(0.22) \\
-1.16(0.26)\end{array}$ & $\begin{array}{l}24 \\
24\end{array}$ & 0.71 & 2.74 & $9.61 *$ \\
\hline
\end{tabular}

Notes: 1 . The $\chi^{2}$ statistics of columns 6 and 12 test the hypothesis of the independence of $q-q$ and $d$. Under the null, $\chi^{2}$ has 1 degree of freedom.

2. The F statistics of columns 7 and 13 test the joint hypothesis of $\eta^{\mathrm{h}}=0$ and $\phi^{\mathrm{h}}=-1$. Under the null, F has degrees of freedom equal to 2 and $\mathrm{N}-2$, where $\mathrm{N}$ is the number of observations.

3. An asterisk (*) indicates significant at the 5 percent level. 


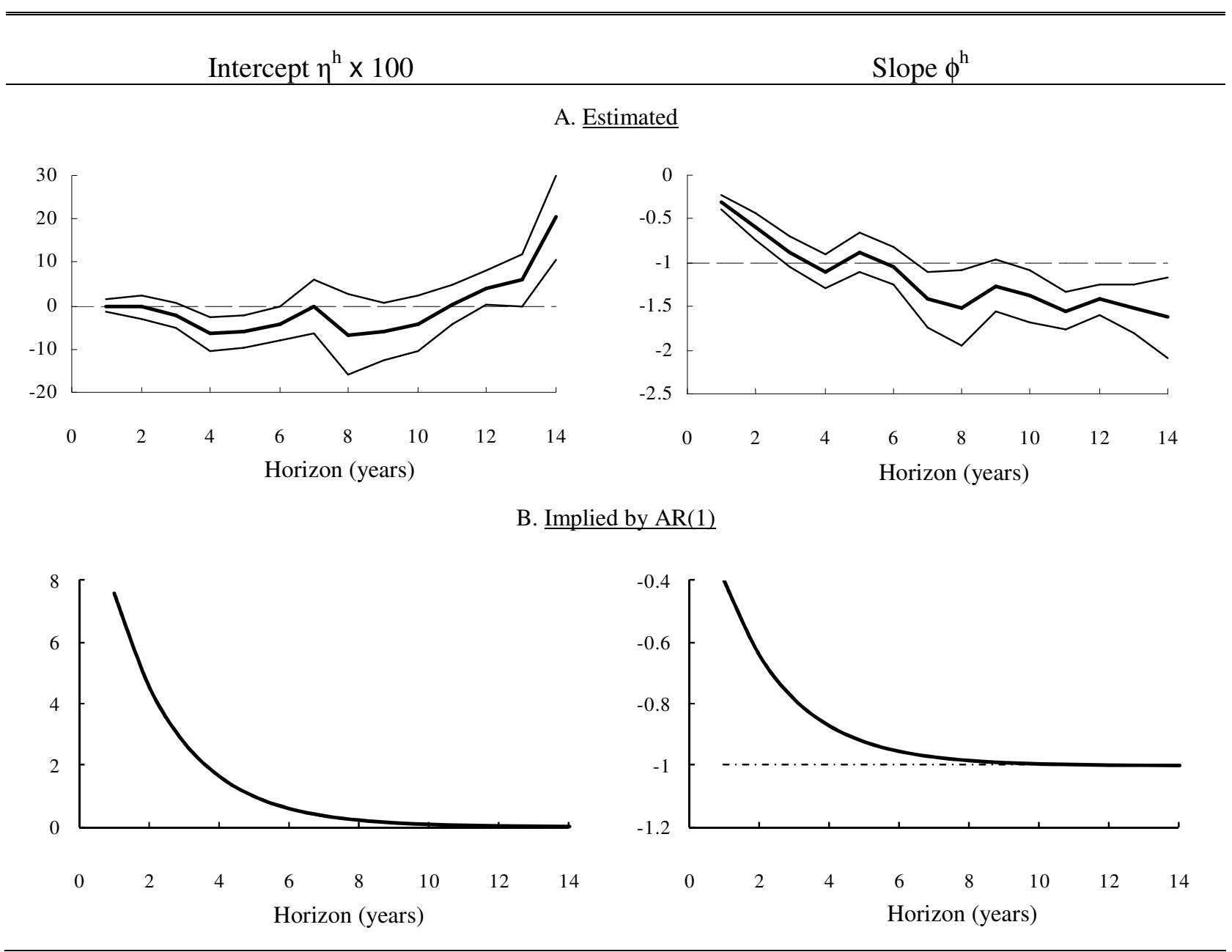

Note: In Panel A the thick lines are estimated parameters, while the thinner lines are the 95 percent confidence limits. 
FIGURE 5.4

THE QUALITY OF THREE SETS OF EXCHANGE-RATE FORECASTS

(Root-Mean-Squared Errors)

A. With overlapping observations

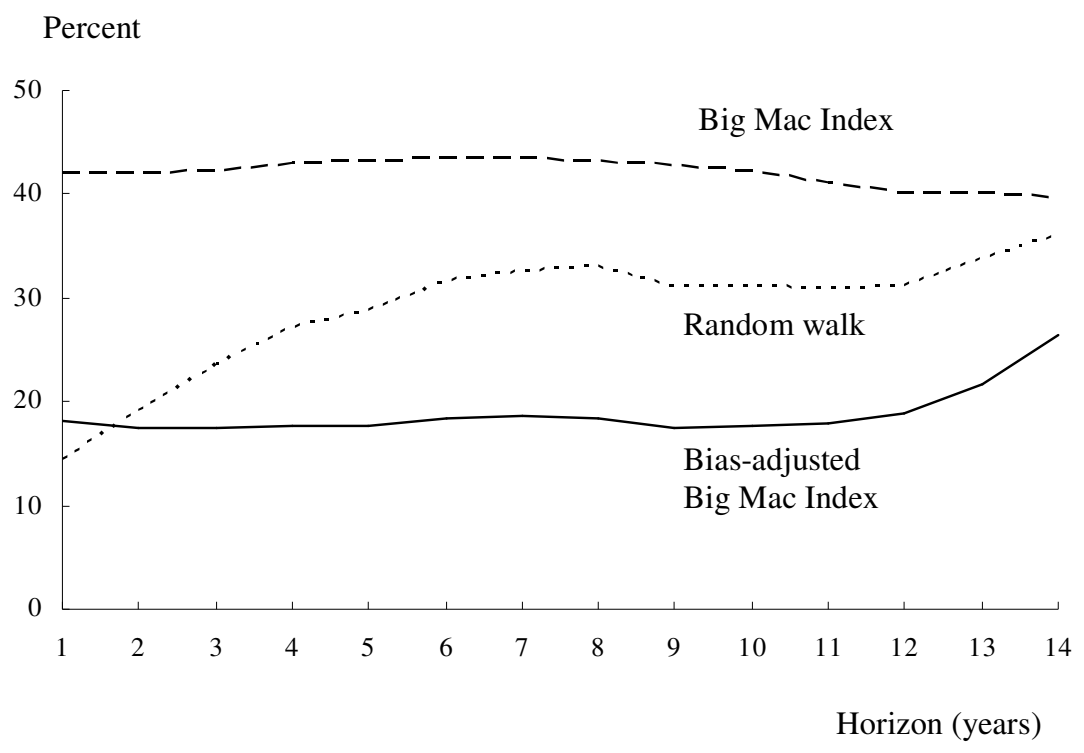

B. Without overlapping observations

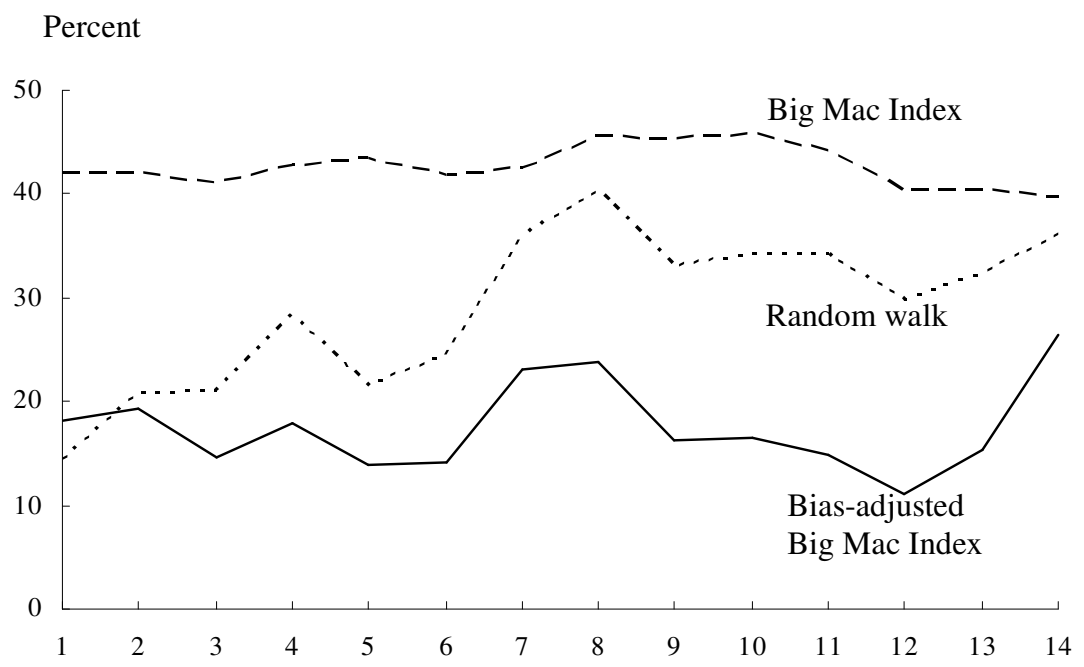

Horizon (years) 
TABLE 6.1

MORE PREDICTIVE REGRESSIONS, 24 COUNTRIES, 1994-2008 (Standard errors in parentheses)

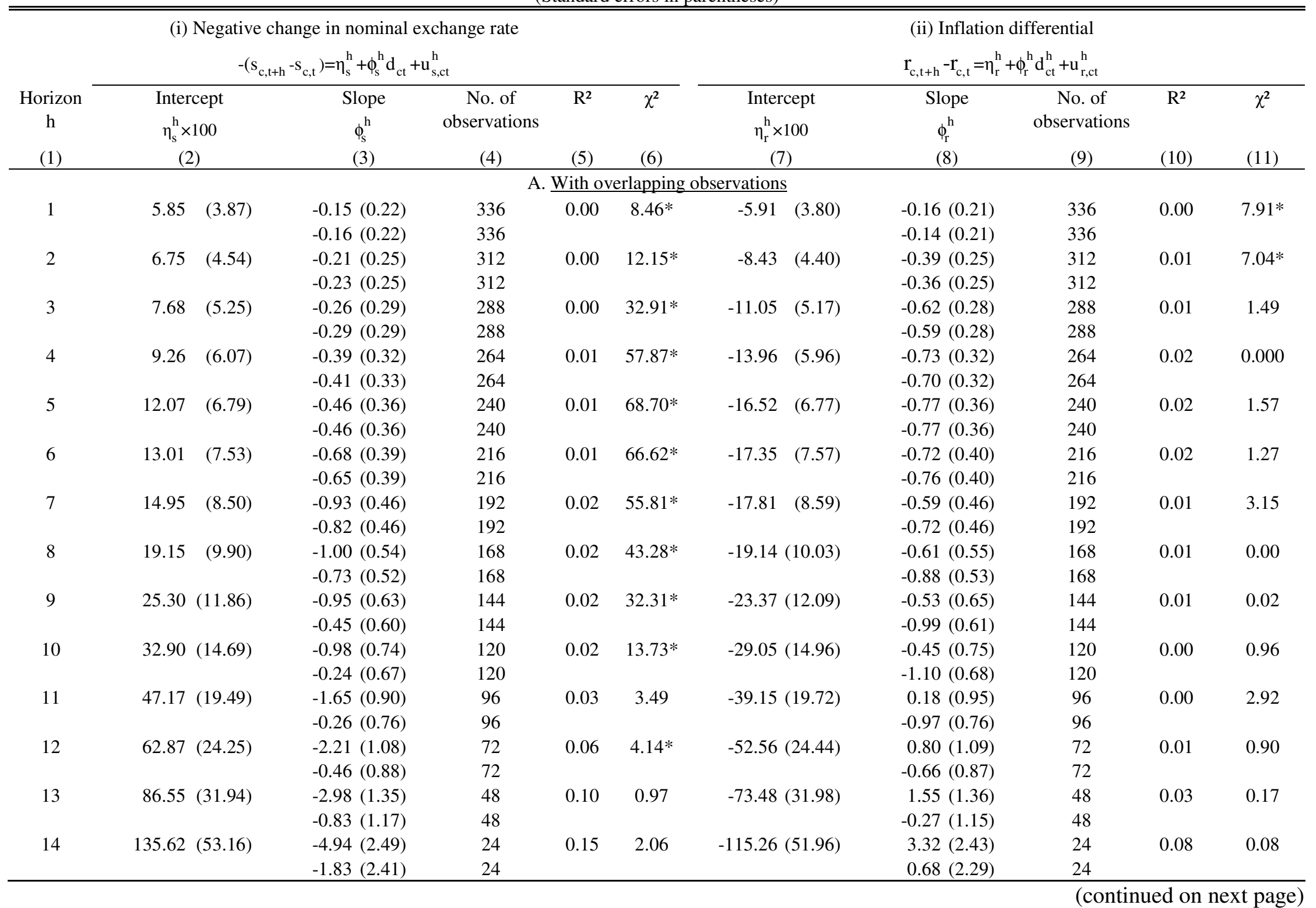


TABLE 6.1 (continued)

MORE PREDICTIVE REGRESSIONS, 24 COUNTRIES, 1994-2008

(Standard errors in parentheses)

\begin{tabular}{|c|c|c|c|c|c|c|c|c|c|c|}
\hline \multirow[b]{2}{*}{$\begin{array}{c}\text { Horizon } \\
\mathrm{h} \\
(1)\end{array}$} & \multicolumn{3}{|c|}{$\begin{array}{l}\text { (i) Negative change in nominal exchange rate } \\
\qquad-\left(\mathrm{s}_{\mathrm{c}, \mathrm{t}+\mathrm{h}}-\mathrm{s}_{\mathrm{c}, \mathrm{t}}\right)=\eta_{\mathrm{s}}^{\mathrm{h}}+\phi_{\mathrm{s}}^{\mathrm{h}} \mathrm{d}_{\mathrm{ct}}+\mathrm{u}_{\mathrm{s}, \mathrm{ct}}\end{array}$} & & & \multicolumn{5}{|c|}{$\begin{array}{l}\text { (ii) Inflation differential } \\
\mathrm{r}_{\mathrm{c}, \mathrm{t}+\mathrm{h}}-\mathrm{r}_{\mathrm{c}, \mathrm{t}}=\eta_{\mathrm{r}}^{\mathrm{h}}+\phi_{\mathrm{r}}^{\mathrm{h}} \mathrm{d}_{\mathrm{ct}}^{\mathrm{h}}+\mathrm{u}_{\mathrm{r}, \mathrm{ct}}^{\mathrm{h}}\end{array}$} \\
\hline & $\begin{array}{c}\text { Intercept } \\
\eta_{\mathrm{s}}^{\mathrm{h}} \times 100 \\
(2)\end{array}$ & $\begin{array}{c}\text { Slope } \\
\phi_{\mathrm{s}}^{\mathrm{h}} \\
(3)\end{array}$ & $\begin{array}{c}\text { No. of } \\
\text { observations } \\
\text { (4) }\end{array}$ & $\begin{array}{l}\mathrm{R}^{2} \\
(5) \\
\end{array}$ & $\begin{array}{l}\chi^{2} \\
(6)\end{array}$ & $\begin{array}{c}\text { Intercept } \\
\eta_{\mathrm{r}}^{\mathrm{h}} \times 100 \\
(7)\end{array}$ & $\begin{array}{c}\text { Slope } \\
\phi_{r}^{\mathrm{h}} \\
(8)\end{array}$ & $\begin{array}{c}\text { No. of } \\
\text { observations } \\
(9) \\
\end{array}$ & $\begin{array}{l}\mathrm{R}^{2} \\
(10)\end{array}$ & $\begin{array}{c}\chi^{2} \\
(11)\end{array}$ \\
\hline \multicolumn{11}{|c|}{ B. Without overlapping observations } \\
\hline 1 & $5.85 \quad(3.87)$ & $\begin{array}{l}-0.15(0.22) \\
-0.16(0.22)\end{array}$ & $\begin{array}{l}336 \\
336\end{array}$ & 0.00 & $8.46^{*}$ & $-5.91 \quad(3.79)$ & $\begin{array}{l}-0.16(0.21) \\
-0.14(0.21)\end{array}$ & $\begin{array}{l}336 \\
336\end{array}$ & 0.00 & $7.91 *$ \\
\hline 2 & $11.55 \quad(7.66)$ & $\begin{array}{l}-0.30(0.42) \\
-0.35(0.42)\end{array}$ & $\begin{array}{l}168 \\
168\end{array}$ & 0.00 & $4.92 *$ & $-11.91 \quad(7.46)$ & $\begin{array}{l}-0.28(0.41) \\
-0.23(0.41)\end{array}$ & $\begin{array}{l}168 \\
168\end{array}$ & 0.00 & $9.00^{*}$ \\
\hline 3 & $17.24(13.14)$ & $\begin{array}{l}-0.71(0.76) \\
-0.68(0.76)\end{array}$ & $\begin{array}{l}96 \\
96\end{array}$ & 0.01 & $15.02 *$ & $-19.45(12.96)$ & $\begin{array}{l}-0.16(0.75) \\
-0.20(0.75)\end{array}$ & $\begin{array}{l}96 \\
96\end{array}$ & 0.00 & 0.74 \\
\hline 4 & $21.06(17.56)$ & $\begin{array}{l}-0.54(0.85) \\
-0.66(0.84)\end{array}$ & $\begin{array}{l}72 \\
72\end{array}$ & 0.01 & $15.47^{*}$ & $-27.52(17.29)$ & $\begin{array}{l}-0.56(0.84) \\
-0.40(0.84)\end{array}$ & $\begin{array}{l}72 \\
72\end{array}$ & 0.01 & 0.16 \\
\hline 5 & $36.34(24.78)$ & $\begin{array}{l}-1.79(1.46) \\
-1.31(1.44)\end{array}$ & $\begin{array}{l}48 \\
48\end{array}$ & 0.03 & $15.97 *$ & $-42.28(24.85)$ & $\begin{array}{l}0.92(1.47) \\
0.35(1.46)\end{array}$ & $\begin{array}{l}48 \\
48\end{array}$ & 0.01 & 0.01 \\
\hline 6 & $35.33(23.92)$ & $\begin{array}{l}-1.43(1.25) \\
-1.32(1.27)\end{array}$ & $\begin{array}{l}48 \\
48\end{array}$ & 0.03 & $18.55^{*}$ & $-39.56(24.38)$ & $\begin{array}{l}0.40(1.28) \\
0.27(1.30)\end{array}$ & $\begin{array}{l}48 \\
48\end{array}$ & 0.00 & 0.17 \\
\hline 7 & 39.73 (23.72) & $\begin{array}{l}-1.72(1.17) \\
-1.85(1.19)\end{array}$ & $\begin{array}{l}48 \\
48\end{array}$ & 0.05 & $30.08^{*}$ & $-39.87(24.25)$ & $\begin{array}{l}0.30(1.20) \\
0.43(1.22)\end{array}$ & $\begin{array}{l}48 \\
48\end{array}$ & 0.00 & $8.07 *$ \\
\hline 8 & $92.91(52.50)$ & $\begin{array}{ll}-4.31 & (2.45) \\
-2.18 & (2.24)\end{array}$ & $\begin{array}{l}24 \\
24\end{array}$ & 0.12 & $6.40^{*}$ & $-99.61(53.62)$ & $\begin{array}{l}2.80(2.51) \\
0.52(2.30)\end{array}$ & $\begin{array}{l}24 \\
24\end{array}$ & 0.05 & 0.00 \\
\hline 9 & $99.31 \quad(51.33)$ & $\begin{array}{ll}-4.31 & (2.40) \\
-2.03 & (2.22)\end{array}$ & $\begin{array}{l}24 \\
24\end{array}$ & 0.13 & $5.45^{*}$ & $-105.24(52.74)$ & $\begin{array}{l}3.05(2.47) \\
0.64(2.29)\end{array}$ & $\begin{array}{l}24 \\
24\end{array}$ & 0.07 & 0.06 \\
\hline 10 & 104.54 & $\begin{array}{l}-4.36(2.37) \\
-1.97(2.22)\end{array}$ & $\begin{array}{l}24 \\
24\end{array}$ & 0.13 & 3.56 & $-108.70(52.58)$ & $\begin{array}{l}2.98(2.46) \\
0.49(2.29)\end{array}$ & $\begin{array}{l}24 \\
24\end{array}$ & 0.06 & 0.00 \\
\hline 11 & $112.15(51.65)$ & $\begin{array}{l}-4.49(2.42) \\
-1.92(2.27)\end{array}$ & $\begin{array}{l}24 \\
24\end{array}$ & 0.14 & 2.74 & $-111.93(52.49)$ & $\begin{array}{l}2.94(2.46) \\
0.38(2.30)\end{array}$ & $\begin{array}{l}24 \\
24\end{array}$ & 0.06 & 0.08 \\
\hline 12 & 115.14 (51.97) & $\begin{array}{ll}-4.57 & (2.43) \\
-1.93 & (2.29)\end{array}$ & $\begin{array}{l}24 \\
24\end{array}$ & 0.14 & 2.74 & $-111.09(52.18)$ & $\begin{array}{l}3.14(2.44) \\
0.60(2.29)\end{array}$ & $\begin{array}{l}24 \\
24\end{array}$ & 0.07 & 0.30 \\
\hline 13 & $123.58 \quad(52.21)$ & $\begin{array}{l}-4.79(2.44) \\
-1.96(2.33)\end{array}$ & $\begin{array}{l}24 \\
24\end{array}$ & 0.15 & 2.06 & $-117.64(51.79)$ & $\begin{array}{l}3.27(2.42) \\
0.57(2.30)\end{array}$ & $\begin{array}{l}24 \\
24\end{array}$ & 0.08 & 0.08 \\
\hline 14 & $135.62(53.16)$ & $\begin{array}{l}-4.94(2.49) \\
-1.83(2.41)\end{array}$ & $\begin{array}{l}24 \\
24\end{array}$ & 0.15 & 2.06 & $-115.26(51.96)$ & $\begin{array}{ll}3.32 & (2.43) \\
0.68 & (2.29)\end{array}$ & $\begin{array}{l}24 \\
24\end{array}$ & 0.08 & 0.08 \\
\hline
\end{tabular}

Notes: 1 . The $\chi^{2}$ statistics in columns 6 and 11 test the hypotheses of the independence between $-\left(s_{c, t+h}-s_{c, t}\right)$ and $d_{c t}$, and $r_{c, t+h}-r_{c, t}$ and $d_{c t}$, respectively. Under the null, $\chi^{2}$ has 1 degree of freedom.

2. An asterisk $(*)$ indicates significant at the 5 percent level. 
TABLE 6.2

SEEMINGLY UNRELATED REGRESSIONS UNDER FULL ADJUSTMENT, 24 COUNTRIES, 1994-2008

\begin{tabular}{|c|c|c|c|c|c|c|}
\hline \multirow[b]{2}{*}{$\begin{array}{l}\text { Horizon } \\
\qquad \begin{array}{c}\mathrm{H} \\
(1)\end{array}\end{array}$} & \multicolumn{3}{|c|}{ With overlapping observations } & \multicolumn{3}{|c|}{ Without overlapping observations } \\
\hline & $\begin{array}{c}\text { Intercept } \\
\eta_{\mathrm{s}}^{\mathrm{H}} \times 100 \\
\quad(2)\end{array}$ & \multirow{2}{*}{$\begin{array}{c}\text { Slope } \\
\phi_{\mathrm{s}}^{\mathrm{H}} \\
(3) \\
-0.72(0.21)\end{array}$} & $\begin{array}{c}\text { No. of } \\
\text { observations } \\
(4)\end{array}$ & $\begin{array}{l}\text { Intercept } \\
\eta_{\mathrm{s}}^{\mathrm{H}} \times 100 \\
\quad(5)\end{array}$ & \multirow{2}{*}{$\begin{array}{c}\text { Slope } \\
\phi_{\mathrm{s}}^{\mathrm{H}} \\
(6) \\
-0.72(0.21)\end{array}$} & \multirow{2}{*}{$\begin{array}{c}\text { No. of } \\
\text { observations } \\
(7) \\
336\end{array}$} \\
\hline \multirow[t]{2}{*}{1} & $5.90 \quad(3.79)$ & & 336 & $5.90 \quad(3.79)$ & & \\
\hline & & $-0.74(0.21)$ & 336 & & $-0.74(0.21)$ & 336 \\
\hline \multirow[t]{2}{*}{2} & $8.38 \quad(4.42)$ & $-0.60(0.25)$ & 312 & $11.97 \quad(7.42)$ & $-0.78(0.40)$ & 168 \\
\hline & & $-0.61(0.25)$ & 312 & & $-0.83(0.41)$ & 168 \\
\hline \multirow[t]{2}{*}{3} & $10.79 \quad(5.15)$ & $-0.37(0.28)$ & 288 & $20.66(12.80)$ & $-0.91(0.74)$ & 96 \\
\hline & & $-0.39(0.28)$ & 288 & & $-0.84(0.75)$ & 96 \\
\hline \multirow[t]{2}{*}{4} & $14.09 \quad(5.94)$ & $-0.27(0.32)$ & 264 & 30.79 (17.02) & $-0.39(0.82)$ & 72 \\
\hline & & $-0.32(0.32)$ & 264 & & $-0.60(0.83)$ & 72 \\
\hline \multirow[t]{2}{*}{5} & $14.80 \quad(6.73)$ & $-0.32(0.36)$ & 240 & $36.95(24.26)$ & $-1.81(1.43)$ & 48 \\
\hline & & $-0.37(0.36)$ & 240 & & $-1.26(1.41)$ & 48 \\
\hline \multirow[t]{2}{*}{6} & $14.36 \quad(7.49)$ & $-0.56(0.39)$ & 216 & $26.54(23.04)$ & $-1.51(1.21)$ & 48 \\
\hline & & $-0.61(0.39)$ & 216 & & $-1.46(1.21)$ & 48 \\
\hline \multirow[t]{2}{*}{7} & $15.14 \quad(8.46)$ & $-0.90(0.46)$ & 192 & $39.65(23.15)$ & $-1.97(1.14)$ & 48 \\
\hline & & $-0.86(0.46)$ & 192 & & $-2.10(1.17)$ & 48 \\
\hline \multirow[t]{2}{*}{8} & $19.16 \quad(9.83)$ & $-1.11(0.53)$ & 168 & $84.01 \quad(49.70)$ & $-4.99(2.33)$ & 24 \\
\hline & & $-0.84(0.52)$ & 168 & & $-3.64(2.13)$ & 24 \\
\hline \multirow[t]{2}{*}{9} & $26.48(11.75)$ & $-1.25(0.63)$ & 144 & 74.44 (46.53) & $-5.41(2.18)$ & 24 \\
\hline & & $-0.66(0.59)$ & 144 & & $-4.41(1.96)$ & 24 \\
\hline \multirow[t]{2}{*}{10} & $35.57(14.52)$ & $-1.28(0.73)$ & 120 & 85.92 (45.67) & $-6.07(2.14)$ & 24 \\
\hline & & $-0.38(0.67)$ & 120 & & $-4.68(1.98)$ & 24 \\
\hline \multirow[t]{2}{*}{11} & $49.86(19.27)$ & $-1.81(0.93)$ & 96 & 112.76 (48.49) & $-6.05(2.27)$ & 24 \\
\hline & & $-0.18(0.76)$ & 96 & & $-3.43(2.19)$ & 24 \\
\hline \multirow[t]{2}{*}{12} & $63.46(23.92)$ & $-2.23(1.07)$ & 72 & 119.41 (49.67) & $-5.01(2.32)$ & 24 \\
\hline & & $-0.34(0.87)$ & 72 & & $-1.30(2.24)$ & 24 \\
\hline \multirow[t]{2}{*}{13} & $81.25(31.24)$ & $-2.81(1.33)$ & 48 & 111.47 (49.46) & $-3.72(2.31)$ & 24 \\
\hline & & $-0.64(1.13)$ & 48 & & $-0.27(2.19)$ & 24 \\
\hline \multirow[t]{2}{*}{14} & $94.84(49.41)$ & $-3.69(2.31)$ & 24 & 94.84 (49.41) & $-3.69(2.31)$ & 24 \\
\hline & & $-1.09(2.03)$ & 24 & & $-1.09(2.03)$ & 24 \\
\hline
\end{tabular}


FIGURE 7.1

\section{IMPLICATIONS OF MISPRICING}

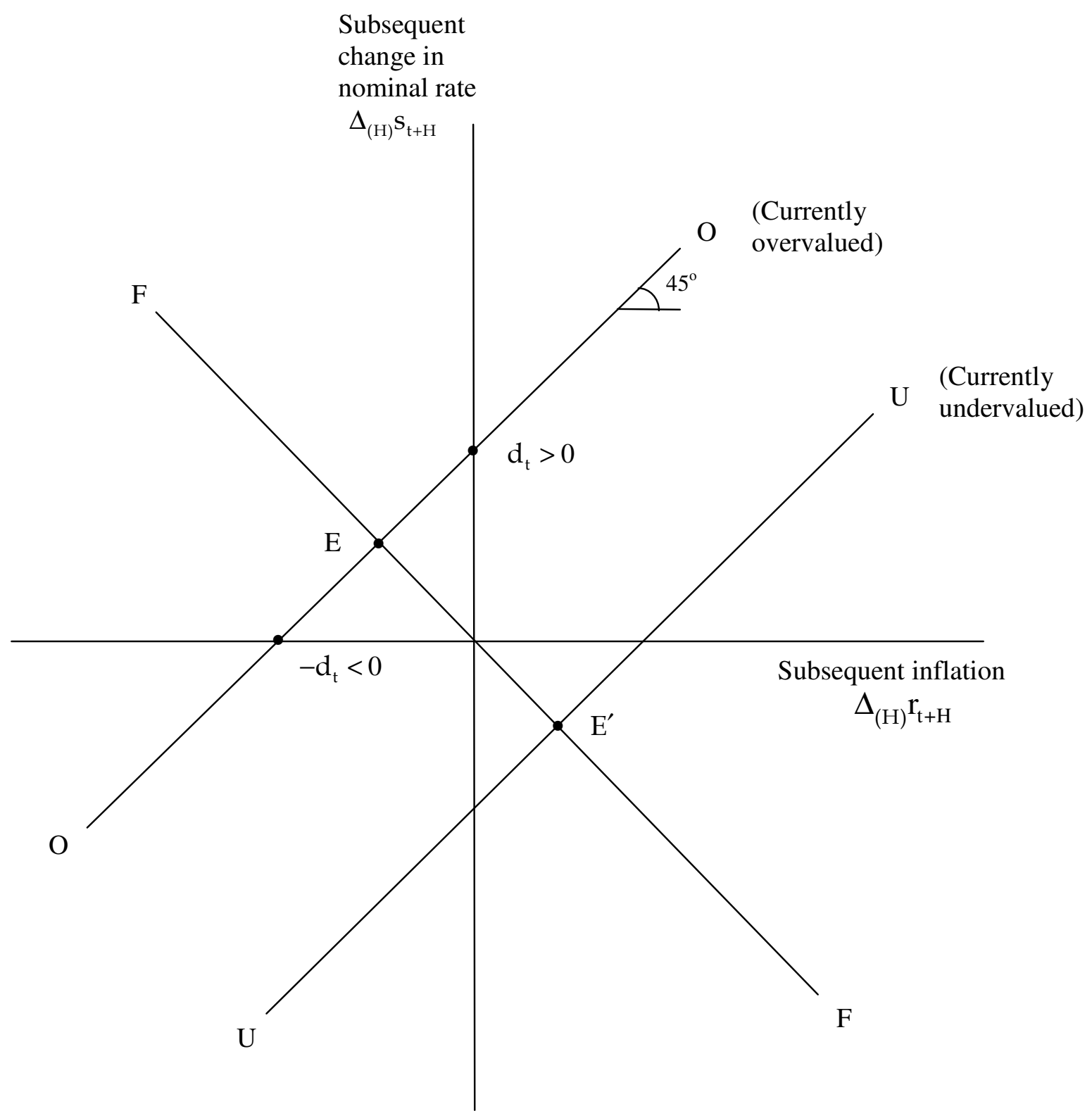


TABLE 8.1

PREDICTIVE REGRESSIONS FOR REAL EXCHANGE RATES WITH TIME DUMMIES, 24 COUNTRIES, 1994-2008

$\mathrm{q}_{\mathrm{c}, \mathrm{t}+\mathrm{h}}-\mathrm{q}_{\mathrm{c}, \mathrm{t}}=\sum_{\tau} \alpha_{\tau, \tau+\mathrm{h}} \mathrm{D}_{\tau, \mathrm{t}}+\phi^{\mathrm{h}} \mathrm{d}_{\mathrm{c}, \mathrm{t}}+\mathrm{u}_{\mathrm{c}, \mathrm{t}}^{\mathrm{h}} \quad$ (Standard errors in parentheses)

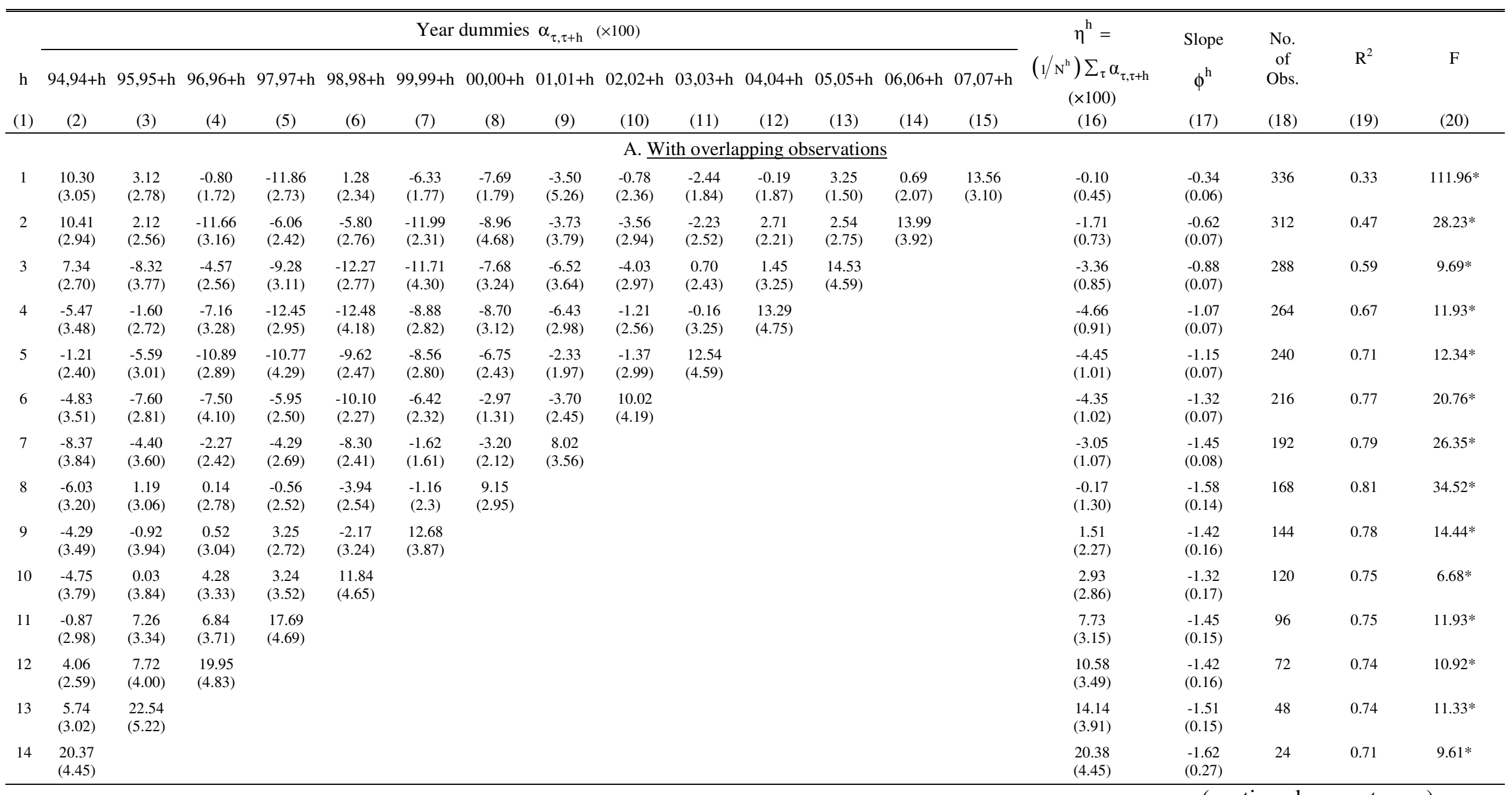

(continued on next page) 
TABLE 8.1 (continued)

PREDICTIVE REGRESSIONS FOR REAL EXCHANGE RATES WITH TIME DUMMIES, 24 COUNTRIES, 1994-2008

$\mathrm{q}_{\mathrm{c}, \mathrm{t}+\mathrm{h}}-\mathrm{q}_{\mathrm{c}, \mathrm{t}}=\sum_{\tau} \alpha_{\tau, \tau+\mathrm{h}} \mathrm{D}_{\tau, \mathrm{t}}+\phi^{\mathrm{h}} \mathrm{d}_{\mathrm{c}, \mathrm{t}}+\mathrm{u}_{\mathrm{c}, \mathrm{t}}^{\mathrm{h}} \quad$ (Standard errors in parentheses)

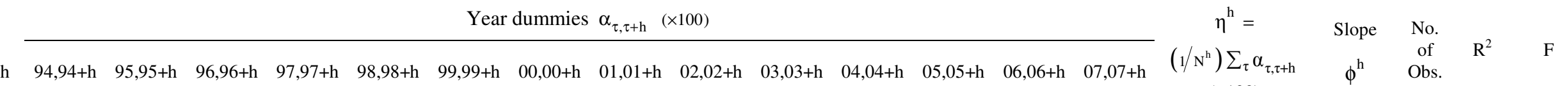

\begin{tabular}{|c|c|c|c|c|c|c|c|c|c|c|c|c|c|c|c|c|c|c|c|}
\hline (1) & $(2)$ & $(3)$ & (4) & (5) & $(6)$ & (7) & $(8)$ & (9) & $(10)$ & $(11)$ & $(12)$ & $(13)$ & $(14)$ & $(15)$ & $(16)$ & $(17)$ & $(18)$ & $(19)$ & $(20)$ \\
\hline \multicolumn{20}{|c|}{ B. Without overlapping observations } \\
\hline 1 & $\begin{array}{l}10.30 \\
(3.05)\end{array}$ & $\begin{array}{c}3.12 \\
(2.78)\end{array}$ & $\begin{array}{l}-0.80 \\
(1.72)\end{array}$ & $\begin{array}{l}-11.86 \\
(2.73)\end{array}$ & $\begin{array}{c}1.28 \\
(2.34)\end{array}$ & $\begin{array}{l}-6.33 \\
(1.77)\end{array}$ & $\begin{array}{l}-7.69 \\
(1.79)\end{array}$ & $\begin{array}{l}-3.50 \\
(5.26)\end{array}$ & $\begin{array}{l}-0.78 \\
(2.36)\end{array}$ & $\begin{array}{l}-2.44 \\
(1.84)\end{array}$ & $\begin{array}{l}-0.19 \\
(1.87)\end{array}$ & $\begin{array}{c}3.25 \\
(1.50)\end{array}$ & $\begin{array}{c}0.69 \\
(2.07)\end{array}$ & $\begin{array}{l}13.56 \\
(3.10)\end{array}$ & $\begin{array}{l}-0.10 \\
(0.45)\end{array}$ & $\begin{array}{l}-0.34 \\
(0.06)\end{array}$ & 336 & 0.33 & $111.96 *$ \\
\hline 2 & $\begin{array}{l}10.29 \\
(3.05)\end{array}$ & & $\begin{array}{l}-11.83 \\
(3.29)\end{array}$ & & $\begin{array}{l}-5.73 \\
(2.79)\end{array}$ & & $\begin{array}{l}-8.86 \\
(4.77)\end{array}$ & & $\begin{array}{l}-3.42 \\
(3.05)\end{array}$ & & $\begin{array}{c}2.81 \\
(2.16)\end{array}$ & & $\begin{array}{l}13.99 \\
(3.90)\end{array}$ & & $\begin{array}{c}-0.392 \\
(0.84)\end{array}$ & $\begin{array}{l}-0.61 \\
(0.07)\end{array}$ & 168 & 0.46 & $13.39 *$ \\
\hline 3 & $\begin{array}{c}7.99 \\
(2.64)\end{array}$ & & & $\begin{array}{c}-8.69 \\
(3.04)\end{array}$ & & & $\begin{array}{l}-8.18 \\
(3.15)\end{array}$ & & & $\begin{array}{c}0.16 \\
(2.38)\end{array}$ & & & & & $\begin{array}{l}-2.18 \\
(0.48)\end{array}$ & $\begin{array}{l}-0.94 \\
(0.07)\end{array}$ & 96 & 0.63 & 1.54 \\
\hline 4 & $\begin{array}{c}-5.23 \\
(3.16)\end{array}$ & & & & $\begin{array}{r}-12.62 \\
(3.92)\end{array}$ & & & & $\begin{array}{l}-1.48 \\
(2.52)\end{array}$ & & & & & & $\begin{array}{c}-6.45 \\
(1.57)\end{array}$ & $\begin{array}{l}-1.09 \\
(0.09)\end{array}$ & 72 & 0.68 & $5.54^{*}$ \\
\hline 5 & $\begin{array}{l}-3.52 \\
(2.25)\end{array}$ & & & & & $\begin{array}{l}-7.94 \\
(2.89)\end{array}$ & & & & & & & & & $\begin{array}{l}-5.73 \\
(1.57)\end{array}$ & $\begin{array}{l}-0.93 \\
(0.10)\end{array}$ & 48 & 0.57 & $4.41^{*}$ \\
\hline 6 & $\begin{array}{l}-9.02 \\
(2.56)\end{array}$ & & & & & & $\begin{array}{c}0.29 \\
(2.29)\end{array}$ & & & & & & & & $\begin{array}{l}-4.36 \\
(0.70)\end{array}$ & $\begin{array}{l}-0.92 \\
(0.08)\end{array}$ & 48 & 0.72 & 2.78 \\
\hline 7 & $\begin{array}{c}-12.48 \\
(2.80)\end{array}$ & & & & & & & $\begin{array}{l}13.14 \\
(4.93)\end{array}$ & & & & & & & $\begin{array}{c}0.33 \\
(2.06)\end{array}$ & $\begin{array}{l}-1.05 \\
(0.17)\end{array}$ & 48 & 0.73 & 0.06 \\
\hline 8 & $\begin{array}{l}-6.71 \\
(3.88)\end{array}$ & & & & & & & & & & & & & & $\begin{array}{l}-6.71 \\
(3.88)\end{array}$ & $\begin{array}{l}-1.51 \\
(0.40)\end{array}$ & 24 & 0.70 & $7.80^{*}$ \\
\hline 9 & $\begin{array}{l}-5.94 \\
(3.85)\end{array}$ & & & & & & & & & & & & & & $\begin{array}{l}-5.94 \\
(3.85)\end{array}$ & $\begin{array}{l}-1.26 \\
(0.22)\end{array}$ & 24 & 0.77 & $6.75^{*}$ \\
\hline 10 & $\begin{array}{c}-4.13 \\
(3.80)\end{array}$ & & & & & & & & & & & & & & $\begin{array}{l}-4.16 \\
(3.76)\end{array}$ & $\begin{array}{l}-1.38 \\
(0.21)\end{array}$ & 24 & 0.81 & $8.17^{*}$ \\
\hline 11 & $\begin{array}{c}0.22 \\
(2.49)\end{array}$ & & & & & & & & & & & & & & $\begin{array}{c}0.22 \\
(2.49)\end{array}$ & $\begin{array}{l}-1.55 \\
(0.12)\end{array}$ & 24 & 0.91 & $18.01^{*}$ \\
\hline 12 & $\begin{array}{c}4.05 \\
(1.88)\end{array}$ & & & & & & & & & & & & & & $\begin{array}{c}4.05 \\
(1.88)\end{array}$ & $\begin{array}{l}-1.42 \\
(0.09)\end{array}$ & 24 & 0.92 & $11.55^{*}$ \\
\hline 13 & $\begin{array}{c}5.94 \\
(2.86)\end{array}$ & & & & & & & & & & & & & & $\begin{array}{c}5.94 \\
(2.86)\end{array}$ & $\begin{array}{l}-1.53 \\
(0.16)\end{array}$ & 24 & 0.85 & $7.58^{*}$ \\
\hline 14 & $\begin{array}{l}20.37 \\
(4.44)\end{array}$ & & & & & & & & & & & & & & $\begin{array}{l}20.37 \\
(4.45)\end{array}$ & $\begin{array}{l}-1.62 \\
(0.27)\end{array}$ & 24 & 0.71 & $9.61^{*}$ \\
\hline
\end{tabular}

Notes: $\quad$ 1. The F statistics of column 20 test the joint hypothesis of $\eta^{\mathrm{h}}=0$ and $\phi^{\mathrm{h}}=-1$ for various values of $\mathrm{h}$.

2. An asterisk $(*)$ indicates significant at the 5 percent level.

3. Standard errors are robust, based on a cluster correction (Kleok, 1981). 
TABLE 9.1

THE BURGERNOMICS LITERATURE

\begin{tabular}{|c|c|c|}
\hline & Author & Key Results \\
\hline 1. & Cumby (1996) & $\begin{array}{l}\text { Deviations from Big Mac PPP tend to die out; half-life is about } 1 \text { year; the Big Mac is a } \\
\text { useful exchange-rate predictor }\end{array}$ \\
\hline 2. & Click (1996) & PPP holds in time-series dimension; departure is due to the productivity bias \\
\hline 3. & $\begin{array}{l}\text { Pakko and } \\
\text { Pollard (1996) }\end{array}$ & $\begin{array}{l}\text { Deviations from absolute PPP are persistent and those from relative PPP are transitory; } \\
\text { Big Macs are a useful but flawed PPP measure }\end{array}$ \\
\hline 4. & $\begin{array}{l}\text { Annaert and } \\
\text { Ceuster (1997) }\end{array}$ & Relative Big Mac PPP is a valuable international asset allocator \\
\hline 5. & Ong (1997) & $\begin{array}{l}\text { BMI surprisingly accurate in tracking exchange rates over the long term (revision of } \\
\text { Ong, 1995) }\end{array}$ \\
\hline 6. & Ong (1998a) & BMI good indicator of currency devaluations \\
\hline 7. & Ong (1998b) & $\begin{array}{l}\text { Significant relationship between Big Mac real wages and the productivity bias, market } \\
\text { status and location }\end{array}$ \\
\hline 8. & $\begin{array}{l}\text { Ong and Mitchell } \\
(2000)\end{array}$ & Big Mac academic real wages and quality-of-life indices useful for relocation decisions \\
\hline 9. & $\begin{array}{l}\text { Ashenfelter and } \\
\text { Jurajda (2001) }\end{array}$ & McWages highly correlated with other wage measures \\
\hline 10. & Lutz (2001) & $\begin{array}{l}\text { Results similar to Cumby (1996) obtained using UBS price series and aggregate CPI } \\
\text { data, but are not robust }\end{array}$ \\
\hline 11. & $\begin{array}{l}\text { Fujiki and } \\
\text { Kitamura (2003) }\end{array}$ & Big Mac PPP sensitive to different models, sample periods and countries \\
\hline 12. & $\begin{array}{l}\text { Pakko and } \\
\text { Pollard (2003) }\end{array}$ & BMI useful but imperfect PPP measure \\
\hline 13. & Ong (2003) & Long-run PPP supported by BMI. BMI works as well as other board price indices \\
\hline 14. & $\begin{array}{l}\text { Caetano et al. } \\
(2004)\end{array}$ & Income and trade openness explain failure of Big Mac PPP \\
\hline 15. & Yang (2004) & Big Mac PPP overestimates currency values of low-income countries \\
\hline 16. & Lan (2006) & BMI used to construct entire distribution of future exchange rates \\
\hline 17. & $\begin{array}{l}\text { Monson } \\
\text { (undated) }\end{array}$ & $\begin{array}{l}\text { Adjustment toward parity is slower than that in Cumby (1996) and Ong (1997). The } \\
\text { local price, rather than the nominal exchange rate, does most of the adjusting. }\end{array}$ \\
\hline 18. & $\begin{array}{l}\text { Chen et al. } \\
(2007)\end{array}$ & BMI supports PPP more than does CPI \\
\hline 19. & $\begin{array}{l}\text { Parsley and Wei } \\
(2007)\end{array}$ & $\begin{array}{l}\text { Speed of adjustment for Big Mac PPP slower than that for tradable inputs, but faster } \\
\text { than that for nontradable inputs }\end{array}$ \\
\hline 20. & $\begin{array}{l}\text { Fukumoto } \\
(2009)\end{array}$ & $\begin{array}{l}\text { Big Mac prices suggest that regional price dispersion has diminished within regions, but } \\
\text { global price dispersion has not decreased }\end{array}$ \\
\hline 21. & Winkels (2009) & $\begin{array}{l}\text { Absolute PPP has predictive value for the performance of an international currency } \\
\text { portfolio in the long run }\end{array}$ \\
\hline 22. & $\begin{array}{l}\text { Clementi et al. } \\
(2010)\end{array}$ & $\begin{array}{l}\text { Inflation has increased and no significant reduction in price dispersion since the } \\
\text { introduction of the euro }\end{array}$ \\
\hline 23. & $\begin{array}{l}\text { Clements and } \\
\text { Lan }(2010)\end{array}$ & $\begin{array}{l}\text { Real-time exchange-rate forecasts derived from BMI; these beat random walk over } \\
\text { medium and longer horizons }\end{array}$ \\
\hline
\end{tabular}


TABLE A1

IMPLIED PPP EXCHANGE RATES, 1986 TO 2008

\begin{tabular}{|c|c|c|c|c|c|c|c|c|c|c|c|c|c|c|c|c|c|c|c|c|c|c|c|}
\hline \multirow[t]{2}{*}{ Country } & \multicolumn{23}{|c|}{ Year } \\
\hline & 1986 & 1987 & 1988 & 1989 & 1990 & 1991 & 1992 & 1993 & 1994 & 1995 & 1996 & 1997 & 1998 & 1999 & 2000 & 2001 & 2002 & 2003 & 2004 & 2005 & 2006 & 2007 & 2008 \\
\hline Argentina & & & & & & & 1.51 & 1.58 & 1.57 & 1.29 & 1.27 & 1.03 & 0.98 & 1.03 & 1.00 & 0.98 & 1.00 & 1.51 & 1.50 & 1.55 & 2.26 & 2.42 & 3.08 \\
\hline Aruba & & & & & & & & & & & & & & & & & 0.94 & 1.51 & 1.41 & 1.62 & 1.60 & & \\
\hline Australia & 1.09 & & 0.82 & 1.04 & 1.05 & 1.09 & 1.16 & 1.08 & 1.07 & 1.06 & 1.06 & 1.03 & 1.04 & 1.09 & 1.03 & 1.18 & 1.21 & 1.11 & 1.12 & 1.06 & 1.05 & 1.01 & 0.97 \\
\hline Austria & & & & & & & & & 14.8 & 16.8 & 15.3 & 14.1 & 13.3 & & & & & & & & & & \\
\hline Bahrain & & & & & & & & & & & & & & & & & 0.34 & 0.31 & & & & & \\
\hline Belarus & & & & & & & & & & & & & & & & & 916 & 904 & 1021 & & & & \\
\hline Belgium & 56.3 & 56.3 & 37.7 & 44.6 & 44.1 & 44.4 & 49.3 & 47.8 & 47.4 & 47.0 & 46.2 & 45.0 & 42.6 & & & & & & & & & & \\
\hline Brazil & 7.80 & & & & & & 1735 & 33772 & 652 & 1.04 & 1.25 & 1.23 & 1.21 & 1.21 & 1.18 & 1.42 & 1.45 & 1.68 & 1.86 & 1.93 & 2.07 & 2.02 & 2.10 \\
\hline Britain & 0.69 & 0.71 & 0.50 & 0.62 & 0.64 & 0.74 & 0.80 & 0.79 & 0.79 & 0.75 & 0.76 & 0.75 & 0.72 & 0.78 & 0.76 & 0.78 & 0.80 & 0.73 & 0.65 & 0.61 & 0.63 & 0.58 & 0.64 \\
\hline Bulgaria & & & & & & & & & & & & & & & & & & 1.10 & 1.03 & 0.98 & 0.97 & & \\
\hline Canada & 1.18 & & 0.86 & 1.06 & 1.00 & 1.04 & 1.26 & 1.21 & 1.24 & 1.19 & 1.21 & 1.20 & 1.09 & 1.23 & 1.14 & 1.31 & 1.34 & 1.18 & 1.10 & 1.07 & 1.14 & 1.14 & 1.15 \\
\hline Chile & & & & & & & & & 412 & 410 & 403 & 496 & 488 & 518 & 502 & 496 & 562 & 517 & 483 & 490 & 503 & 459 & 434 \\
\hline China & & & & & & & 2.88 & 3.73 & 3.91 & 3.88 & 4.07 & 4.01 & 3.87 & 4.07 & 3.94 & 3.90 & 4.22 & 3.65 & 3.59 & 3.43 & 3.39 & 3.23 & 3.50 \\
\hline Colombia & & & & & & & & & & & & & & & & & 2289 & 2288 & 2241 & 2124 & 2097 & 2023 & 1961 \\
\hline Costa Rica & & & & & & & & & & & & & & & & & 351 & 417 & 390 & 369 & 365 & 331 & 504 \\
\hline Croatia & & & & & & & & & & & & & & & & & 5.98 & 5.50 & 5.14 & 4.87 & 4.84 & & \\
\hline Czech Republic & & & & & & & & & 21.7 & 21.6 & 21.6 & 21.9 & 21.1 & & 21.7 & 22.1 & 22.6 & 20.9 & 19.5 & 18.4 & 19.1 & 15.5 & 18.5 \\
\hline Denmark & & 13.4 & 9.52 & 12.3 & 11.6 & 11.9 & 12.4 & 11.3 & 11.2 & 11.5 & 10.9 & 10.6 & 9.30 & 10.2 & 9.86 & 9.74 & 9.94 & 10.2 & 9.57 & 9.07 & 8.95 & 8.14 & 7.84 \\
\hline Dominican Rep & & & & & & & & & & & & & & & & & 20.1 & 22.1 & 20.7 & 19.6 & 19.4 & & \\
\hline Egypt & & & & & & & & & & & & & & & & & & 2.95 & 3.45 & 2.94 & 3.07 & 2.80 & 3.64 \\
\hline Estonia & & & & & & & & & & & & & & & & & 11.5 & 10.9 & 10.2 & 9.64 & 9.52 & 8.80 & 8.96 \\
\hline Euro Area & & & & & & & & & & & & & & 1.04 & 1.02 & 1.01 & 1.07 & 1.00 & 0.94 & 0.95 & 0.95 & 0.90 & 0.94 \\
\hline Fiji & & & & & & & & & & & & & & & & & & & 1.47 & 1.39 & 1.50 & & \\
\hline France & 10.3 & 10.9 & 7.24 & 8.76 & 8.05 & 8.00 & 8.27 & 8.11 & 8.04 & 7.97 & 7.42 & 7.23 & 6.84 & 7.20 & 7.37 & 7.28 & & & & & & & \\
\hline Georgia & & & & & & & & & & & & & & & & & & 1.35 & 1.26 & 1.19 & 1.34 & & \\
\hline Germany & & & & & & 1.91 & 2.01 & 2.02 & 2.00 & 2.07 & 2.08 & 2.03 & 1.93 & 2.04 & 1.99 & 2.01 & & & & & & & \\
\hline Greece & & & & & & & & & 270 & & & & & & & & & & & & & & \\
\hline Guatemala & & & & & & & & & & & & & & & & & 6.43 & 5.90 & 5.52 & 5.47 & 5.57 & & \\
\hline Holland & 2.72 & 2.81 & 2.03 & 2.53 & 2.39 & 2.33 & 2.44 & 2.39 & 2.37 & 2.35 & 2.31 & 2.25 & 2.13 & 2.24 & & & & & & & & & \\
\hline Honduras & & & & & & & & & & & & & & & & & & 9.58 & 12.4 & 11.7 & 11.6 & & \\
\hline Hong Kong & 4.75 & & 3.18 & 3.76 & 3.91 & 3.96 & 4.06 & 3.95 & 4.00 & 4.10 & 4.20 & 4.09 & 3.98 & 4.20 & 4.06 & 4.21 & 4.50 & 4.24 & 4.14 & 3.92 & 3.87 & 3.52 & 3.73 \\
\hline
\end{tabular}


TABLE A1 (continued)

IMPLIED PPP EXCHANGE RATES, 1986 TO 2008

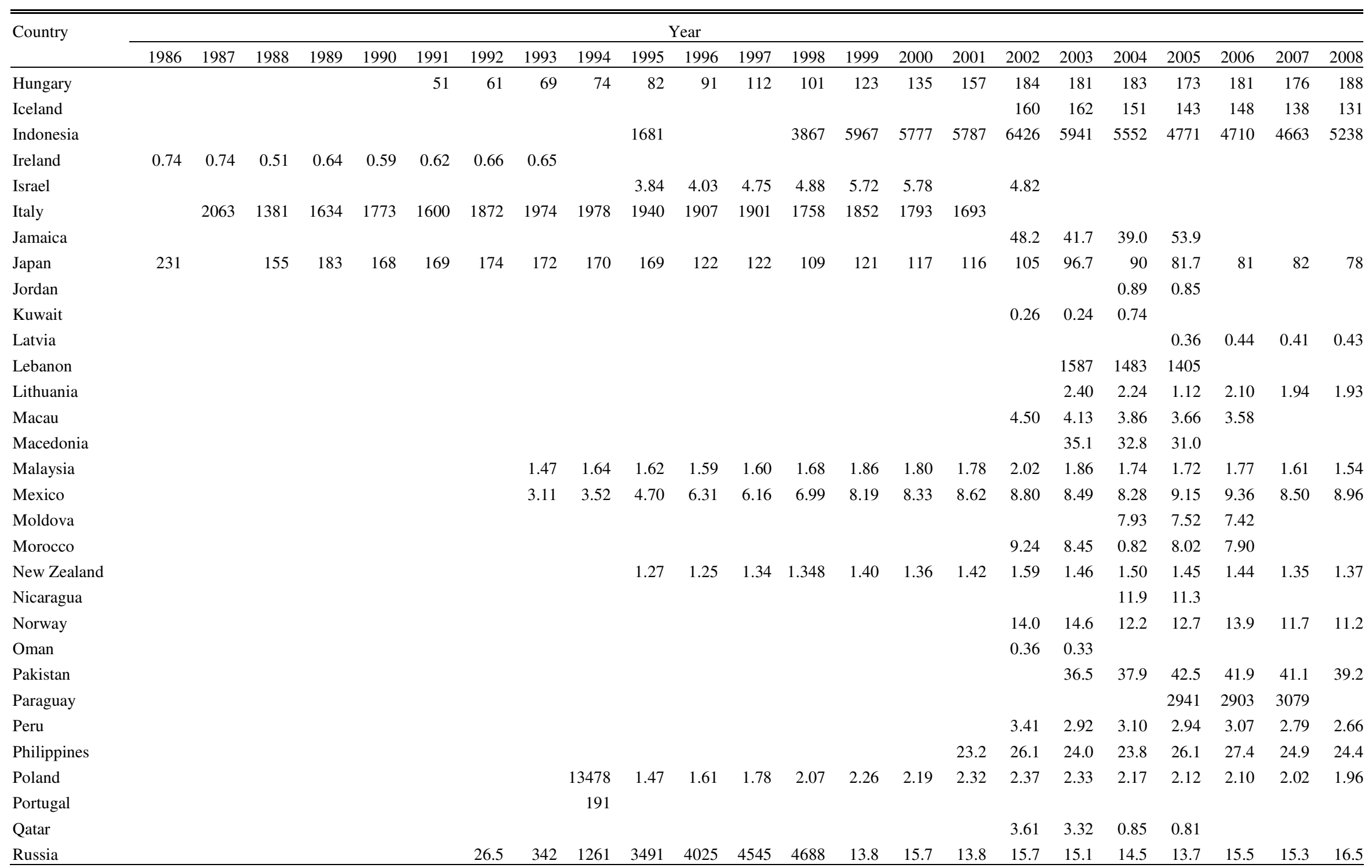


TABLE A1 (continued)

IMPLIED PPP EXCHANGE RATES, 1986 TO 2008

\begin{tabular}{|c|c|c|c|c|c|c|c|c|c|c|c|c|c|c|c|c|c|c|c|c|c|c|c|}
\hline \multirow[t]{2}{*}{ Country } & \multicolumn{23}{|c|}{ Year } \\
\hline & 1986 & 1987 & 1988 & 1989 & 1990 & 1991 & 1992 & 1993 & 1994 & 1995 & 1996 & 1997 & 1998 & 1999 & 2000 & 2001 & 2002 & 2003 & 2004 & 2005 & 2006 & 2007 & 2008 \\
\hline Saudi Arabia & & & & & & & & & & & & & & & & & 3.62 & 3.32 & 0.83 & 2.94 & 2.90 & 2.64 & 2.80 \\
\hline $\begin{array}{l}\text { Serbia \& } \\
\text { Montenegro }\end{array}$ & & & & & & & & & & & & & & & & & & & & 45.8 & & & \\
\hline Singapore & 1.75 & & 1.17 & 1.39 & 1.18 & 1.24 & 2.17 & & 1.30 & 1.27 & 1.29 & 1.24 & 1.17 & 1.32 & 1.28 & 1.30 & 1.33 & 1.22 & 1.14 & 1.18 & 1.16 & 1.16 & 1.11 \\
\hline Slovakia & & & & & & & & & & & & & & & & & 25.3 & 24.4 & 22.8 & 21.6 & 18.7 & 18.0 & 21.6 \\
\hline Slovenia & & & & & & & & & & & & & & & & & 172.7 & 177.1 & 166.0 & 163.0 & 167.7 & & \\
\hline South Africa & & & & & & & & & & & 2.97 & 3.22 & 3.13 & 3.54 & 3.59 & 3.82 & 3.90 & 5.15 & 4.28 & 4.56 & 4.50 & 4.55 & 4.73 \\
\hline South Korea & & & & 1188 & 955 & 933 & 1050 & 1009 & 1000 & 991 & 975 & 950 & 1016 & 1235 & 1195 & 1181 & 1245 & 1218 & 1103 & 817 & 807 & 850 & 896 \\
\hline Soviet Union & & & & & 1.71 & 4.44 & & & & & & & & & & & & & & & & & \\
\hline Spain & 163 & & 119 & 139 & 134 & 156 & 144 & 143 & 150 & 153 & 155 & 155 & 147 & 154 & 149 & 156 & & & & & & & \\
\hline Sri Lanka & & & & & & & & & & & & & & & & & & 50.0 & 48.3 & 57.2 & 61.3 & 61.6 & 58.8 \\
\hline Suriname & & & & & & & & & & & & & & & & & 2410 & 2952 & & & & & \\
\hline Sweden & 10.3 & & 7.74 & 10.4 & 10.9 & 11.6 & 11.6 & 11.2 & 11.1 & 11.2 & 11.0 & 10.7 & 9.38 & 9.88 & 9.56 & 9.45 & 10.4 & 11.1 & 10.3 & 10.1 & 10.7 & 9.68 & 10.6 \\
\hline Switzerland & & & & & & & & 2.50 & 2.48 & 2.54 & 2.50 & 2.44 & 2.31 & 2.43 & 2.35 & 2.48 & 2.53 & 2.33 & 2.17 & 2.06 & 2.03 & 1.85 & 1.82 \\
\hline Taiwan & & & & & & & & & 27.0 & 28.0 & 27.5 & 28.1 & 26.6 & 28.8 & 27.9 & 27.6 & 28.1 & 25.8 & 25.9 & 24.5 & 24.2 & 22.0 & 21.0 \\
\hline Thailand & & & & & & & & 21.1 & 20.9 & 20.7 & 20.3 & 19.3 & 20.3 & 21.4 & 21.9 & 21.7 & 22.1 & 21.8 & 20.3 & 19.6 & 19.4 & 18.2 & 17.4 \\
\hline Turkey & & & & & & & & & & & & & & & & & 6064251 & 383763 & 62069 & 1.31 & 1.36 & 1.39 & 1.44 \\
\hline Ukraine & & & & & & & & & & & & & & & & & 3.53 & 2.58 & 2.5 & 2.37 & 2.74 & 2.71 & 3.08 \\
\hline UAE & & & & & & & & & & & & & & & & & 3.61 & 3.32 & 0.84 & 2.94 & 2.90 & 2.93 & 2.80 \\
\hline Uruguay & & & & & & & & & & & & & & & & & 11.3 & 11.0 & 10.3 & 14.4 & 13.7 & 18.2 & 17.1 \\
\hline Venezuela & & & & & & & 77.6 & & & & & & & & & & 1004 & 1365 & 1517 & 1830 & 1839 & 2170 & \\
\hline West Germany & 2.66 & 2.56 & 1.72 & 2.13 & 1.96 & & & & & & & & & & & & & & & & & & \\
\hline Yugoslavia & & & 962 & 3465 & 7.27 & 14.2 & & & & & & & & & & & 34.1 & 38.8 & & & & & \\
\hline
\end{tabular}

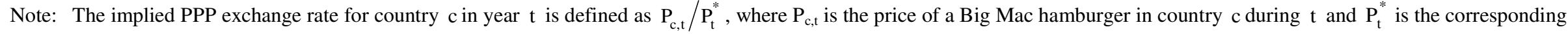
price in the US. 
TABLE A2

NOMINAL EXCHANGE RATES, 1986 TO 2008

\begin{tabular}{|c|c|c|c|c|c|c|c|c|c|c|c|c|c|c|c|c|c|c|c|c|c|c|c|}
\hline \multirow[t]{2}{*}{ Country } & \multicolumn{23}{|c|}{ Year } \\
\hline & 1986 & 1987 & 1988 & 1989 & 1990 & 1991 & 1992 & 1993 & 1994 & 1995 & 1996 & 1997 & 1998 & 1999 & 2000 & 2001 & 2002 & 2003 & 2004 & 2005 & 2006 & 2007 & 2008 \\
\hline Argentina & & & & & & & 0.99 & 1.00 & 1.00 & 1.00 & 1.00 & 1.00 & 1.00 & 1.00 & 1.00 & 1.00 & 3.13 & 2.88 & 2.94 & 2.89 & 3.06 & 3.09 & 3.02 \\
\hline Aruba & & & & & & & & & & & & & & & & & 1.79 & 1.79 & 1.79 & 1.79 & 1.79 & & \\
\hline Australia & 1.64 & & 1.36 & 1.24 & 1.32 & 1.27 & 1.31 & 1.39 & 1.42 & 1.35 & 1.27 & 1.29 & 1.51 & 1.59 & 1.68 & 1.98 & 1.86 & 1.61 & 1.43 & 1.30 & 1.33 & 1.17 & 1.03 \\
\hline Austria & & & & & & & & & 12.0 & 9.72 & 10.7 & 12.0 & 13.0 & & & & & & & & & & \\
\hline Bahrain & & & & & & & & & & & & & & & & & 0.38 & 0.38 & & & & & \\
\hline Belarus & & & & & & & & & & & & & & & & & 1745 & 2018 & 2161 & & & & \\
\hline Belgium & 42.0 & 39.1 & 34.8 & 39.5 & 34.7 & 34.5 & 33.6 & 32.5 & 35.2 & 28.4 & 31.2 & 35.3 & 38.0 & & & & & & & & & & \\
\hline Brazil & 13.8 & & & & & & 2153 & 27521 & 949 & 0.90 & 0.99 & 1.06 & 1.14 & 1.73 & 1.79 & 2.19 & 2.34 & 3.07 & 3.17 & 2.47 & 2.30 & 1.91 & 1.58 \\
\hline Britain & 0.67 & 0.679 & 0.54 & 0.59 & 0.61 & 0.56 & 0.57 & 0.64 & 0.69 & 0.62 & 0.66 & 0.61 & 0.60 & 0.62 & 0.63 & 0.70 & 0.69 & 0.63 & 0.56 & 0.55 & 0.53 & 0.50 & 0.50 \\
\hline Bulgaria & & & & & & & & & & & & & & & & & & 1.78 & 1.62 & 1.60 & 1.54 & & \\
\hline Canada & 1.39 & & 1.24 & 1.19 & 1.16 & 1.15 & 1.19 & 1.26 & 1.39 & 1.39 & 1.36 & 1.39 & 1.42 & 1.51 & 1.47 & 1.56 & 1.57 & 1.45 & 1.37 & 1.25 & 1.12 & 1.05 & 1.00 \\
\hline Chile & & & & & & & & & 414 & 395 & 408 & 417 & 455 & 484 & 514 & 601 & 655 & 716 & 643 & 593 & 530 & 527 & 494 \\
\hline China & & & & & & & 5.44 & 5.68 & 8.70 & 8.54 & 8.35 & 8.33 & 8.28 & 8.28 & 8.28 & 8.28 & 8.28 & 8.28 & 8.26 & 8.26 & 8.03 & 7.60 & 6.83 \\
\hline Colombia & & & & & & & & & & & & & & & & & 2261 & 2914 & 2765 & 2330 & 2504 & 1956 & 1799 \\
\hline Costa Rica & & & & & & & & & & & & & & & & & 351 & 390 & 433 & 474 & 510 & 519 & 551 \\
\hline Croatia & & & & & & & & & & & & & & & & & 8.29 & 6.87 & 6.16 & 5.96 & 5.72 & & \\
\hline Czech Republic & & & & & & & & & 29.7 & 26.2 & 27.6 & 29.2 & 34.4 & & 39.1 & 39.0 & 34.0 & 28.9 & 26.6 & 24.5 & 22.1 & 21.1 & 14.5 \\
\hline Denmark & & 7.19 & 6.36 & 7.33 & 6.39 & 6.42 & 6.32 & 6.06 & 6.69 & 5.43 & 5.85 & 6.52 & 7.02 & 6.91 & 8.04 & 8.46 & 8.38 & 6.78 & 6.22 & 6.06 & 5.82 & 5.46 & 4.70 \\
\hline Dominican Rep & & & & & & & & & & & & & & & & & 17.2 & 23.0 & 45.5 & 28.3 & 32.6 & & \\
\hline Egypt & & & & & & & & & & & & & & & & & & 5.92 & 6.18 & 5.80 & 5.77 & 5.69 & 5.31 \\
\hline Estonia & & & & & & & & & & & & & & & & & 17.6 & 14.3 & 13.0 & 12.8 & 12.3 & 11.5 & 9.87 \\
\hline Euro Area & & & & & & & & & & & & & & 0.93 & 1.08 & 1.14 & 1.12 & 0.91 & 0.83 & 0.81 & 0.78 & 0.73 & 0.63 \\
\hline Fiji & & & & & & & & & & & & & & & & & & & 1.81 & 1.70 & 1.73 & & \\
\hline France & 6.65 & 6.30 & 5.63 & 6.37 & 5.63 & 5.65 & 5.55 & 5.34 & 5.83 & 4.80 & 5.13 & 5.76 & 6.17 & 6.10 & 7.07 & 7.44 & & & & & & & \\
\hline Georgia & & & & & & & & & & & & & & & & & & 2.21 & 1.92 & 1.82 & 1.80 & & \\
\hline Germany & & & & & & 1.67 & 1.64 & 1.58 & 1.71 & 1.38 & 1.52 & 1.71 & 1.84 & 1.82 & 2.11 & 2.22 & & & & & & & \\
\hline \multicolumn{24}{|l|}{ Greece } \\
\hline Guatemala & & & & & & & & & & & & & & & & & 7.90 & 7.87 & 7.96 & 7.61 & 7.59 & & \\
\hline Holland & 2.28 & 2.13 & 1.86 & 2.13 & 1.88 & 1.88 & 1.84 & 1.77 & 1.91 & 1.55 & 1.70 & 1.92 & 2.07 & 2.05 & & & & & & & & & \\
\hline Honduras & & & & & & & & & & & & & & & & & & 17.2 & 18.2 & 18.7 & 18.9 & & \\
\hline Hong Kong & 7.80 & & 7.80 & 7.78 & 7.79 & 7.79 & 7.73 & 7.73 & 7.73 & 7.73 & 7.74 & 7.75 & 7.75 & 7.75 & 7.79 & 7.80 & 7.80 & 7.80 & 7.80 & 7.79 & 7.75 & 7.82 & 7.80 \\
\hline
\end{tabular}


TABLE A2 (continued)

NOMINAL EXCHANGE RATES, 1986 TO 2008

\begin{tabular}{|c|c|c|c|c|c|c|c|c|c|c|c|c|c|c|c|c|c|c|c|c|c|c|c|}
\hline \multirow[t]{2}{*}{ Country } & \multicolumn{23}{|c|}{ Year } \\
\hline & 1986 & 1987 & 1988 & 1989 & 1990 & 1991 & 1992 & 1993 & 1994 & 1995 & 1996 & 1997 & 1998 & 1999 & 2000 & 2001 & 2002 & 2003 & 2004 & 2005 & 2006 & 2007 & 2008 \\
\hline Hungary & & & & & & 75 & 80 & 88 & 103 & 121 & 150 & 178 & 213 & 237 & 279 & 303 & 272 & 224 & 211 & 204 & 206 & 180 & 144 \\
\hline Iceland & & & & & & & & & & & & & & & & & 96.3 & 75.8 & 72.9 & 65.6 & 72.0 & 61.7 & 78.6 \\
\hline Indonesia & & & & & & & & & & 2231 & & & 8500 & 8725 & 7945 & 10855 & 9430 & 8740 & 9096 & 9542 & 9325 & 9015 & 9152 \\
\hline Ireland & 0.74 & 0.70 & 0.62 & 0.71 & 0.63 & 0.62 & 0.61 & 0.65 & & & & & & & & & & & & & & & \\
\hline Israel & & & & & & & & & & 2.95 & 3.17 & 3.38 & 3.70 & 4.04 & 4.05 & & 4.79 & & & & & & \\
\hline Italy & & 1342 & 1229 & 1382 & 1230 & 1239 & 1233 & 1523 & 1641 & 1702 & 1551 & 1683 & 1818 & 1799 & 2088 & 2195 & & & & & & & \\
\hline Jamaica & & & & & & & & & & & & & & & & & 47.4 & 56.7 & 60.2 & 61.1 & & & \\
\hline Japan & 154 & & 124 & 133 & 159 & 135 & 133 & 113 & 104 & 84 & 107 & 126 & 135 & 120 & 106 & 124 & 130 & 120 & 112 & 107 & 112 & 122 & 107 \\
\hline Jordan & & & & & & & & & & & & & & & & & & & 0.71 & 0.71 & & & \\
\hline Kuwait & & & & & & & & & & & & & & & & & 0.31 & 0.30 & 0.29 & & & & \\
\hline Latvia & & & & & & & & & & & & & & & & & & & 0.55 & 0.57 & 0.55 & 0.51 & 0.44 \\
\hline Lebanon & & & & & & & & & & & & & & & & & & 1512 & 1514 & 1509 & & & \\
\hline Lithuania & & & & & & & & & & & & & & & & & & 3.15 & 2.87 & 2.80 & 2.69 & 2.53 & 2.18 \\
\hline Macau & & & & & & & & & & & & & & & & & 8.03 & 8.03 & 8.00 & 8.00 & 7.99 & & \\
\hline Macedonia & & & & & & & & & & & & & & & & & & 55.8 & 51.7 & 49.9 & & & \\
\hline Malaysia & & & & & & & & 2.58 & 2.69 & 2.49 & 2.49 & 2.50 & 3.72 & 3.80 & 3.80 & 3.80 & 3.80 & 3.80 & 3.79 & 3.81 & 3.63 & 3.43 & 3.20 \\
\hline Mexico & & & & & & & & 3.10 & 3.36 & 6.37 & 7.37 & 7.90 & 8.54 & 9.54 & 9.41 & 9.29 & 9.28 & 10.5 & 11.5 & 10.9 & 11.3 & 10.8 & 10.2 \\
\hline Moldova & & & & & & & & & & & & & & & & & & & 11.9 & 12.5 & 13.2 & & \\
\hline Morocco & & & & & & & & & & & & & & & & & 11.5 & 9.82 & 9.15 & 8.99 & 8.71 & & \\
\hline New Zealand & & & & & & & & & & 1.51 & 1.47 & 1.45 & 1.82 & 1.87 & 2.01 & 2.47 & 2.24 & 1.78 & 1.64 & 1.40 & 1.62 & 1.28 & 1.32 \\
\hline Nicaragua & & & & & & & & & & & & & & & & & & & 15.8 & 16.4 & & & \\
\hline Norway & & & & & & & & & & & & & & & & & 8.56 & 7.16 & 6.83 & 6.41 & 6.10 & 5.81 & 5.08 \\
\hline Oman & & & & & & & & & & & & & & & & & 0.39 & 0.39 & & & & & \\
\hline Pakistan & & & & & & & & & & & & & & & & & & 57.8 & 57.9 & 59.7 & 60.1 & 60.4 & 70.9 \\
\hline Paraguay & & & & & & & & & & & & & & & & & & & & 6250 & 5505 & 5145 & \\
\hline Peru & & & & & & & & & & & & & & & & & 3.43 & 3.46 & 3.50 & 3.26 & 3.26 & 3.17 & 2.84 \\
\hline Philippines & & & & & & & & & & & & & & & & 50.3 & 51.0 & 52.5 & 56.1 & 54.3 & 52.6 & 45.9 & 44.5 \\
\hline Poland & & & & & & & & & 22433 & 2.34 & 2.64 & 3.10 & 3.46 & 3.98 & 4.30 & 4.03 & 4.04 & 3.89 & 3.86 & 3.31 & 3.10 & 2.75 & 2.03 \\
\hline Portugal & & & & & & & & & 174 & & & & & & & & & & & & & & \\
\hline Qatar & & & & & & & & & & & & & & & & & 3.64 & 3.64 & 3.63 & 3.65 & & & \\
\hline Russia & & & & & & & 99.0 & 686 & 1775 & 4985 & 4918 & 5739 & 5999 & 24.7 & 28.5 & 28.9 & 31.2 & 31.1 & 29.0 & 28.3 & 27.1 & 25.6 & 23.2 \\
\hline
\end{tabular}


TABLE A2 (continued)

NOMINAL EXCHANGE RATES, 1986 TO 2008

\begin{tabular}{|c|c|c|c|c|c|c|c|c|c|c|c|c|c|c|c|c|c|c|c|c|c|c|c|}
\hline \multirow[t]{2}{*}{ Country } & \multicolumn{23}{|c|}{ Year } \\
\hline & 1986 & 1987 & 1988 & 1989 & 1990 & 1991 & 1992 & 1993 & 1994 & 1995 & 1996 & 1997 & 1998 & 1999 & 2000 & 2001 & 2002 & 2003 & 2004 & 2005 & 2006 & 2007 & 2008 \\
\hline Saudi Arabia & & & & & & & & & & & & & & & & & 3.75 & 3.75 & 3.76 & 3.75 & 3.75 & 3.75 & 3.75 \\
\hline Serbia \& Montenegro & & & & & & & & & & & & & & & & & & & & 67.4 & & & \\
\hline Singapore & 2.15 & & 2.00 & 1.96 & 1.88 & 1.77 & 1.65 & & 1.57 & 1.40 & 1.41 & 1.44 & 1.62 & 1.73 & 1.70 & 1.81 & 1.82 & 1.78 & 1.72 & 1.66 & 1.59 & 1.52 & 1.35 \\
\hline Slovakia & & & & & & & & & & & & & & & & & 46.8 & 37.4 & 33.4 & 31.6 & 29.5 & 24.6 & 19.1 \\
\hline Slovenia & & & & & & & & & & & & & & & & & 253 & 212 & 198 & 194 & 189 & & \\
\hline South Africa & & & & & & & & & & & 4.26 & 4.43 & 5.04 & 6.22 & 6.72 & 8.13 & 10.9 & 7.56 & 6.67 & 6.65 & 6.60 & 6.97 & 7.56 \\
\hline South Korea & & & & 666 & 707 & 721 & 778 & 796 & 810 & 769 & 779 & 894 & 1474 & 1218 & 1108 & 1325 & 1304 & 1220 & 1176 & 1004 & 952 & 923 & 1018 \\
\hline Soviet Union & & & & & 0.60 & 1.74 & & & & & & & & & & & & & & & & & \\
\hline Spain & 133 & & 111 & 117 & 106 & 103 & 102 & 114 & 138 & 124 & 126 & 144 & 156 & 155 & 179 & 189 & & & & & & & \\
\hline Sri Lanka & & & & & & & & & & & & & & & & & & 97 & 99 & 100 & 103 & 111 & 108 \\
\hline Suriname & & & & & & & & & & & & & & & & & 2179 & 2515 & & & & & \\
\hline Sweden & 6.87 & & 5.89 & 6.41 & 6.10 & 6.04 & 5.93 & 7.43 & 7.97 & 7.34 & 6.71 & 7.72 & 8.00 & 8.32 & 8.84 & 10.3 & 10.3 & 8.34 & 7.58 & 7.41 & 7.28 & 6.79 & 5.96 \\
\hline Switzerland & & & & & & & & 1.45 & 1.44 & 1.13 & 1.23 & 1.47 & 1.52 & 1.48 & 1.70 & 1.73 & 1.66 & 1.37 & 1.28 & 1.25 & 1.21 & 1.21 & 1.02 \\
\hline Taiwan & & & & & & & & & 26.4 & 25.7 & 27.2 & 27.6 & 33.0 & 33.2 & 30.6 & 32.9 & 34.8 & 34.8 & 33.5 & 31.1 & 32.1 & 32.8 & 30.4 \\
\hline Thailand & & & & & & & & 25.1 & 25.3 & 24.6 & 25.3 & 26.1 & 40.0 & 37.6 & 38.0 & 45.5 & $\begin{array}{r}43.3 \\
13245\end{array}$ & $\begin{array}{r}42.7 \\
16050\end{array}$ & $\begin{array}{r}40.6 \\
15310\end{array}$ & 40.5 & 38.4 & 34.5 & 33.4 \\
\hline Turkey & & & & & & & & & & & & & & & & & $\begin{array}{r}13245 \\
00\end{array}$ & $\begin{array}{r}16050 \\
0\end{array}$ & $\begin{array}{r}15310 \\
07\end{array}$ & 1.37 & 1.54 & 1.30 & 1.19 \\
\hline Ukraine & & & & & & & & & & & & & & & & & 5.33 & 5.34 & 5.33 & 5.07 & 5.05 & 5.03 & 4.60 \\
\hline UAE & & & & & & & & & & & & & & & & & 3.67 & 3.67 & 3.64 & 3.67 & 3.67 & 3.67 & 3.67 \\
\hline Uruguay & & & & & & & & & & & & & & & & & 16.8 & 28.5 & 29.9 & 24.2 & 23.9 & 23.9 & 19.2 \\
\hline Venezuela & & & & & & & 60.6 & & & & & & & & & & 857 & 1598 & 2973 & 2629 & 2630 & 2147 & \\
\hline West Germany & 2.02 & 1.89 & 1.66 & 1.89 & 1.68 & & & & & & & & & & & & & & & & & & \\
\hline Yugoslavia & & & 1400 & 9001 & 11.7 & 15.1 & & & & & & & & & & & 67.8 & 59.2 & & & & & \\
\hline
\end{tabular}

Note: The nominal exchange rate is the domestic currency cost of one US dollar. An increase thus implies a depreciation of the domestic currency and vice versa. 
TABLE A3

REAL EXCHANGE RATES, 1986 TO 2008

\begin{tabular}{|c|c|c|c|c|c|c|c|c|c|c|c|c|c|c|c|c|c|c|c|c|c|c|c|}
\hline \multirow[t]{2}{*}{ Country } & \multicolumn{23}{|c|}{ Year } \\
\hline & 1986 & 1987 & 1988 & 1989 & 1990 & 1991 & 1992 & 1993 & 1994 & 1995 & 1996 & 1997 & 1998 & 1999 & 2000 & 2001 & 2002 & 2003 & $3 \quad 2004$ & $\begin{array}{r}2005 \\
+\end{array}$ & 2006 & 2007 & 2008 \\
\hline Argentina & & & & & & & 42.01 & 45.68 & 44.8 & 25.7 & 24 & 3.252 & -2.372 & 2.84 & -0.399 & -1.587 & -113.7 & -64.38 & -67.27 & -62.37 & -30.39 & -24.47 & 2.007 \\
\hline Aruba & & & & & & & & & & & & & & & & & -64.43 & -16.82 & -23.62 & -9.957 & -11.42 & & \\
\hline Australia & -40.51 & & -51.09 & -17.63 & -23.32 & -15.39 & -12.18 & -25.74 & -28.75 & -24.56 & -18.14 & -22.21 & -37.76 & -37.71 & -48.74 & -51.66 & -43.42 & -37.46 & $5-24.49$ & -20.21 & -23.79 & -14.53 & -6.375 \\
\hline Austria & & & & & & & & & 20.85 & 54.78 & 35.46 & 15.77 & 2.449 & & & & & & & & & & \\
\hline Bahrain & & & & & & & & & & & & & & & & & -10.72 & -19.19 & & & & & \\
\hline Belarus & & & & & & & & & & & & & & & & & -64.49 & -80.3 & $3-74.99$ & & & & \\
\hline Belgium & 29.21 & 36.29 & 7.89 & 12.04 & 24.1 & 25.33 & 38.52 & 38.75 & 29.74 & 50.34 & 39.23 & 24.37 & 11.38 & & & & & & & & & & \\
\hline Brazil & -57.05 & & & & & & -21.58 & 20.47 & -37.51 & 14.76 & 23.32 & 14.65 & 6.037 & -35.42 & -42.07 & -43.51 & -48.15 & -60.35 & -53.41 & -24.71 & -10.8 & 5.771 & 28.49 \\
\hline Britain & 2.578 & 3.899 & -8.115 & 5.565 & 4.231 & 28.17 & 33.21 & 20.27 & 13.89 & 18.86 & 13.57 & 19.81 & 17.66 & 23.02 & 17.9 & 11.36 & 14.74 & 14.86 & $\begin{array}{l}5 \\
6\end{array}$ & 11.71 & 16.26 & 15.96 & $5 \quad 24.91$ \\
\hline Bulgaria & & & & & & & & & & & & & & & & & & -48.16 & $5-44.95$ & -48.71 & -46.79 & & \\
\hline Canada & -16.27 & & -36.86 & -11.16 & -15.3 & -9.628 & 5.738 & -4.006 & -11.14 & -15.2 & -11.53 & -15.53 & -26.46 & -20.47 & -25.82 & -17.39 & -16.04 & -20.54 & -21.88 & -15.14 & 1.373 & 8.033 & 13.6 \\
\hline Chile & & & & & & & & & -0.442 & 3.601 & -1.347 & 17.32 & 7.059 & 6.789 & -2.364 & -19.19 & -15.27 & -32.64 & -28.54 & -19.02 & -5.184 & -13.83 & -12.91 \\
\hline China & & & & & & & -63.71 & -42.11 & -79.9 & -78.91 & -71.92 & -73.15 & -76.13 & -70.92 & -74.16 & -75.35 & -67.48 & -81.83 & -83.36 & -87.94 & -86.32 & -85.7 & -66.82 \\
\hline Colombia & & & & & & & & & & & & & & & & & 1.238 & -24.19 & -21.03 & -9.237 & -17.75 & 3.391 & 8.631 \\
\hline Costa Rica & & & & & & & & & & & & & & & & & 0.115 & 6.688 & -10.54 & -25.13 & -33.58 & -44.86 & $5-8.879$ \\
\hline Croatia & & & & & & & & & & & & & & & & & -32.6 & -22.28 & $3-18.09$ & -20.21 & -16.73 & & \\
\hline Czech Republic & & & & & & & & & -31.2 & -19.53 & -24.47 & -28.76 & -48.91 & & -59.06 & -57.04 & -40.83 & -32.53 & -30.86 & -28.55 & -14.86 & -30.76 & 24.45 \\
\hline Denmark & & 62.55 & 40.32 & 51.38 & 59.55 & 61.62 & 67.74 & 62.25 & 51.49 & 75.3 & 62.33 & 48.98 & 28.09 & 38.8 & 20.41 & 14.13 & 17.07 & 41.23 & 343.04 & 40.33 & 43.05 & 39.91 & 51.21 \\
\hline Dominican Rep & & & & & & & & & & & & & & & & & 15.48 & -3.81 & -78.71 & -36.7 & -52.14 & & \\
\hline Egypt & & & & & & & & & & & & & & & & & & -69.58 & -58.23 & -68.02 & -63.28 & -70.99 & -37.72 \\
\hline Estonia & & & & & & & & & & & & & & & & & -43.03 & -27.28 & -24.49 & -28.12 & -25.66 & -26.79 & -9.633 \\
\hline Euro Area & & & & & & & & & & & & & & 11.33 & -5.285 & -11.61 & -4.674 & 9.531 & 12.31 & 15.69 & 19.39 & 20.58 & 40.61 \\
\hline Fiji & & & & & & & & & & & & & & & & & & & -21.03 & -20.21 & -14.27 & & \\
\hline France & 43.75 & 54.56 & 25.13 & 31.89 & 35.7 & 34.78 & 39.82 & 41.84 & 32.18 & 50.76 & 36.84 & 22.75 & 10.25 & 16.58 & 4.163 & -2.126 & & & & & & & \\
\hline Georgia & & & & & & & & & & & & & & & & & & -49.52 & -42.29 & -42.53 & -29.61 & & \\
\hline Germany & & & & & & 13.49 & 22.55 & 24.45 & 15.67 & 40.5 & 31.19 & 16.9 & 4.961 & 11.27 & -5.953 & -10.04 & & & & & & & \\
\hline \multicolumn{24}{|l|}{ Greece } \\
\hline Guatemala & & & & & & & & & & & & & & & & & -20.66 & -28.74 & + -36.66 & -33 & -31.04 & & \\
\hline Holland & 17.59 & 27.7 & 8.711 & 17 & 23.85 & 21.6 & 28.34 & 30.05 & 21.56 & 41.58 & 30.63 & 15.95 & 2.806 & 8.988 & & & & & & & & & \\
\hline Honduras & & & & & & & & & & & & & & & & & & -58.57 & -38.16 & -47.13 & -48.84 & & \\
\hline Hong Kong & -49.6 & & -89.73 & -72.65 & -68.95 & -67.77 & -64.3 & -67.21 & -65.88 & -63.54 & -61.25 & -63.89 & -66.53 & -61.32 & -65.07 & -61.6 & -55.05 & -60.87 & -63.29 & -68.66 & -69.42 & -79.85 & $5-73.89$ \\
\hline
\end{tabular}

(continued on next page) 
TABLE A3 (continued)

REAL EXCHANGE RATES, 1986 TO 2008

\begin{tabular}{|c|c|c|c|c|c|c|c|c|c|c|c|c|c|c|c|c|c|c|c|c|c|c|c|}
\hline \multirow[t]{2}{*}{ Country } & \multicolumn{23}{|c|}{ Year } \\
\hline & 1986 & 1987 & 1988 & 1989 & 1990 & 1991 & 1992 & 1993 & 1994 & 1995 & 1996 & 1997 & 1998 & 1999 & 2000 & 2001 & 2002 & 2003 & 2004 & 2005 & 2006 & 2007 & 2008 \\
\hline Hungary & & & & & & -38.51 & -27.18 & -24.73 & -33.77 & -38.51 & -50.33 & -46.34 & -74.45 & -65.55 & -72.55 & -65.69 & -38.9 & -21.42 & -14.05 & -16.29 & -13.13 & -2.274 & 26.28 \\
\hline Iceland & & & & & & & & & & & & & & & & & 50.92 & 75.95 & 72.87 & 77.92 & 72.1 & 80.16 & 51.4 \\
\hline Indonesia & & & & & & & & & & -28.3 & & & -78.75 & -37.99 & -31.87 & -62.89 & -38.36 & -38.6 & -49.37 & 161.1 & -68.31 & -65.93 & -55.8 \\
\hline Ireland & -0.338 & 5.488 & -19.44 & -9.824 & -6.406 & 0.358 & 8.196 & -0.035 & & & & & & & & & & & & & & & \\
\hline Israel & & & & & & & & & & 26.27 & 23.89 & 34.07 & 27.74 & 34.78 & 35.51 & & 0.609 & & & & & & \\
\hline Italy & & 43.01 & 11.64 & 16.73 & 36.55 & 25.57 & 41.76 & 25.92 & 18.69 & 13.07 & 20.65 & 12.17 & -3.367 & 2.896 & -15.24 & -25.97 & & & & & & & \\
\hline Jamaica & & & & & & & & & & & & & & & & & 1.659 & -30.7 & -43.34 & -12.52 & & & \\
\hline Japan & 40.65 & & 22.19 & 32.01 & 5.614 & 22.4 & 26.59 & 41.71 & 49.14 & 69.39 & 13.15 & -3.647 & -21.05 & 0.82 & 9.986 & -6.887 & -21.15 & -21.61 & -21.88 & -26.83 & -32.84 & -39.59 & -30.87 \\
\hline Jordan & & & & & & & & & & & & & & & & & & & 23 & 17.9 & & & \\
\hline Kuwait & & & & & & & & & & & & & & & & & -17.19 & -22.38 & 92.73 & & & & \\
\hline Latvia & & & & & & & & & & & & & & & & & & & -37.20 & -46.61 & -23.35 & -22.41 & -1.333 \\
\hline Lebanon & & & & & & & & & & & & & & & & & & 4.847 & -2.091 & -7.11 & & & \\
\hline Lithuania & & & & & & & & & & & & & & & & & & -27.25 & -24.93 & -91.93 & -24.91 & -26.79 & -12.04 \\
\hline Macau & & & & & & & & & & & & & & & & & -57.96 & -66.42 & -72.82 & -78.19 & -80.26 & & \\
\hline Macedonia & & & & & & & & & & & & & & & & & & -46.48 & -45.49 & -47.66 & & & \\
\hline Malaysia & & & & & & & & -56.3 & -49.54 & -42.94 & -44.65 & -44.68 & -79.51 & -71.44 & -74.68 & -75.87 & -62.99 & -71.45 & -77.95 & -79.63 & -71.59 & -75.45 & -73.1 \\
\hline Mexico & & & & & & & & 0.311 & 4.701 & -30.44 & -15.47 & -24.93 & -20 & -15.27 & -12.23 & -7.462 & -5.366 & -21.57 & -33.23 & -17.06 & -18.89 & -23.9 & -12.92 \\
\hline Moldova & & & & & & & & & & & & & & & & & & & -40.72 & -50.86 & -57.61 & & \\
\hline Morocco & & & & & & & & & & & & & & & & & -22.17 & -14.59 & -241.2 & -11.41 & -9.72 & & \\
\hline New Zealand & & & & & & & & & & -17.19 & -16.21 & -7.668 & -30.05 & -29.01 & -39.46 & -55.54 & -34.5 & -19.98 & -9.015 & 3.532 & -12.09 & 5.248 & 3.904 \\
\hline Nicaragua & & & & & & & & & & & & & & & & & & & -28.08 & -37.17 & & & \\
\hline Norway & & & & & & & & & & & & & & & & & 49.6 & 71.08 & 58.01 & 68.33 & 82.15 & 70.26 & 79.1 \\
\hline Oman & & & & & & & & & & & & & & & & & -7.603 & -16.07 & & & & & \\
\hline Pakistan & & & & & & & & & & & & & & & & & & -45.88 & -42.29 & -33.91 & -35.99 & -38.61 & -59.22 \\
\hline Paraguay & & & & & & & & & & & & & & & & & & & & -75.38 & -63.98 & -51.34 & \\
\hline Peru & & & & & & & & & & & & & & & & & -0.478 & -17.14 & -12.08 & -10.32 & -6.184 & -12.92 & -6.508 \\
\hline Philippines & & & & & & & & & & & & & & & & -77.26 & -66.97 & -78.34 & -85.77 & -73.32 & -65.15 & -61.05 & -60.19 \\
\hline Poland & & & & & & & & & -50.95 & -46.79 & -49.44 & -55.66 & -51.36 & -56.44 & -67.41 & -55.1 & -53.36 & -51.48 & -57.61 & -44.55 & -39.1 & -30.68 & -3.469 \\
\hline Portugal & & & & & & & & & 9.481 & & & & & & & & & & & & & & \\
\hline Qatar & & & & & & & & & & & & & & & & & -0.704 & -9.171 & -145 & -150.4 & & & \\
\hline Russia & & & & & & & -131.8 & -69.58 & -34.2 & -35.61 & -20.03 & -23.32 & -24.67 & -58.31 & -59.39 & -74.07 & -68.91 & -72.06 & -69.31 & -72.64 & -55.97 & -51.81 & -33.92 \\
\hline
\end{tabular}


TABLE A3 (continued)

REAL EXCHANGE RATES, 1986 TO 2008

\begin{tabular}{|c|c|c|c|c|c|c|c|c|c|c|c|c|c|c|c|c|c|c|c|c|c|c|c|}
\hline \multirow[t]{2}{*}{ Country } & \multicolumn{23}{|c|}{ Year } \\
\hline & 1986 & 1987 & 1988 & 1989 & 1990 & 1991 & 1992 & 1993 & 1994 & 1995 & 1996 & 1997 & $7 \quad 1998$ & 1999 & 2000 & 2001 & 2002 & 2003 & 2004 & 2005 & 2006 & 2007 & 2008 \\
\hline Saudi Arabia & & & & & & & & & & & & & & & & & -3.681 & -12.15 & -151.1 & -24.29 & -25.59 & -35.12 & -29.17 \\
\hline Serbia \& Montenegro & & & & & & & & & & & & & & & & & & & & -38.6 & & & \\
\hline Singapore & -20.59 & & -53.48 & -34.64 & -46.42 & -35.23 & 27.35 & & -19.21 & -9.623 & -8.711 & -14.98 & -32.38 & -27.29 & -28.78 & -33.16 & -31.72 & -37.96 & -41.24 & -34.37 & -31.42 & -27.17 & $\begin{array}{l}79.9 \\
7\end{array}$ \\
\hline Slovakia & & & & & & & & & & & & & & & & & -61.5 & -42.9 & -38.16 & -38.13 & -45.53 & -31.37 & 12 \\
\hline Slovenia & & & & & & & & & & & & & & & & & -38.19 & -17.97 & -18.09 & -17.84 & -11.93 & & \\
\hline South Africa & & & & & & & & & & & -36.2 & -31.8 & -47.8 & -56.39 & -62.81 & -75.56 & -102.9 & -38.43 & -44.41 & -37.65 & -38.3 & -42.75 & -46.81 \\
\hline South Korea & & & & 57.88 & 30.02 & 25.81 & 30 & 23.69 & 21.07 & 25.4 & 22.4 & 6.119 & -37.25 & 1.351 & 7.577 & -11.5 & -4.632 & -0.188 & -6.408 & -20.61 & -16.59 & -8.188 & -12.73 \\
\hline Soviet Union & & & & & 104.4 & 93.78 & & & & & & & & & & & & & & & & & \\
\hline Spain & 20.03 & & 7.167 & 16.95 & 23.51 & 41.23 & 34.37 & 22.35 & 8.338 & 21.03 & 20.5 & 7.335 & -6.294 & -0.439 & -18.07 & -19.5 & & & & & & & \\
\hline Sri Lanka & & & & & & & & & & & & & & & & & & -70.41 & -72.11 & -55.88 & -51.91 & -58.91 & -60.34 \\
\hline Suriname & & & & & & & & & & & & & & & & & 10.06 & 16.02 & & & & & \\
\hline Sweden & 40.62 & & 27.32 & 48.36 & 58.13 & 64.88 & 67.48 & 40.9 & 33.01 & 42.32 & 49.58 & 33.05 & 15.86 & 17.15 & 7.848 & -8.431 & 1.367 & 28.32 & 30.65 & 30.95 & 38 & 35.43 & 58 \\
\hline Switzerland & & & & & & & & 54.47 & 54.29 & 81.12 & 70.93 & 50.59 & 41.62 & 49.5 & 32.4 & 36.03 & 42.14 & 52.88 & 52.45 & 50.1 & 51.85 & 42.32 & 257.94 \\
\hline Taiwan & & & & & & & & & 2.086 & 8.633 & 1.251 & 1.792 & -21.7 & -14.19 & -9.279 & -17.71 & -21.34 & -29.81 & -25.82 & -23.88 & -28.28 & -39.97 & $7-36.95$ \\
\hline Thailand & & & & & & & & -17.82 & -19.25 & -17.31 & -21.83 & -30.2 & -67.76 & -56.37 & -55.05 & -74.25 & -67.31 & -67.36 & -69.31 & -72.64 & -68.51 & -64.05 & $5-65.4$ \\
\hline Turkey & & & & & & & & & & & & & & & & & 19.3 & -14.55 & -11.69 & -4.683 & -12.81 & 6.907 & 19.25 \\
\hline Ukraine & & & & & & & & & & & & & & & & & -41.2 & -72.63 & -75.72 & -76.07 & -61.07 & -61.75 & -40.07 \\
\hline UAE & & & & & & & & & & & & & & & & & -1.525 & -9.992 & -146.5 & -22.23 & -23.44 & -22.43 & -27.02 \\
\hline Uruguay & & & & & & & & & & & & & & & & & -40.15 & -95.23 & -106.5 & -51.96 & $5-56.05$ & -27.35 & $5 \quad-11.4$ \\
\hline Venezuela & & & & & & & 24.71 & & & & & & & & & & 15.83 & -15.74 & -67.27 & -36.23 & -35.77 & 1.07 & \\
\hline West Germany & 27.38 & 30.61 & 3.288 & 11.89 & 15.14 & & & & & & & & & & & & & & & & & & \\
\hline Yugoslavia & & & -37.49 & -95.45 & -47.72 & -6.121 & & & & & & & & & & & -68.62 & -42.39 & & & & & \\
\hline
\end{tabular}

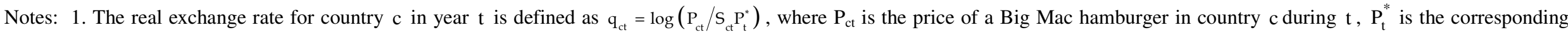
price in the US and $S_{c t}$ is the nominal exchange rate, defined as the domestic currency cost of $\$ U S 1$. A positive value of $q_{c, t}$ implies that the domestic currency is overvalued in real terms and vice versa.

2. All entries are to be divided by 100 . 
TABLE A4

PREDICTIVE REGRESSIONS WITH TIME DUMMIES, CHANGES IN NOMINAL EXCHANGE RATES, 24 COUNTRIES, 1994-2008

$$
-\left(\mathrm{s}_{\mathrm{c}, \mathrm{t}+\mathrm{h}}-\mathrm{s}_{\mathrm{c}, \mathrm{t}}\right)=\sum_{\tau} \alpha_{\mathrm{s}, \tau, \tau+\mathrm{h}} \mathrm{D}_{\tau, \mathrm{t}}+\phi_{\mathrm{s}}^{\mathrm{h}} \mathrm{d}_{\mathrm{c}, \mathrm{t}}+\mathrm{u}_{\mathrm{s}, \mathrm{c}, \mathrm{t}}^{\mathrm{h}} \quad \text { (Standard errors in parentheses) }
$$

\begin{tabular}{|c|c|c|c|c|c|c|c|c|c|c|c|c|c|c|c|c|c|c|}
\hline \multirow[b]{2}{*}{$\begin{array}{l}\mathrm{h} \\
(1) \\
\end{array}$} & \multicolumn{14}{|c|}{ Year dummies $\alpha_{\mathrm{s}, \tau, \tau+\mathrm{h}} \quad(\times 100)$} & \multirow{2}{*}{$\begin{array}{c}\eta^{\mathrm{h}}= \\
\left(1 / \mathrm{N}^{\mathrm{h}}\right) \sum_{\tau} \alpha_{\mathrm{s}, \tau, \tau+\mathrm{h}} \\
(\times 100) \\
(16)\end{array}$} & \multirow{2}{*}{$\begin{array}{l}\text { Slope } \\
\phi_{\mathrm{S}}^{\mathrm{h}} \\
(17)\end{array}$} & \multirow{2}{*}{$\begin{array}{c}\text { No. } \\
\text { of } \\
\text { Obs. } \\
\\
(18)\end{array}$} & \multirow[b]{2}{*}{$\begin{array}{l}\mathrm{R}^{2} \\
\text { (19) } \\
\end{array}$} \\
\hline & $\begin{array}{c}94,94+\mathrm{h} \\
(2)\end{array}$ & $\begin{array}{c}95,95+h \\
(3)\end{array}$ & $\begin{array}{c}96,96+h \\
(4)\end{array}$ & $\begin{array}{c}97,97+h \\
(5)\end{array}$ & $\begin{array}{c}98,98+h \\
(6) \\
\end{array}$ & $\begin{array}{c}99,99+h \\
(7)\end{array}$ & $\begin{array}{c}00,00+h \\
(8) \\
\end{array}$ & $\begin{array}{c}01,01+\mathrm{h} \\
(9)\end{array}$ & $\begin{array}{c}02,02+\mathrm{h} \\
(10)\end{array}$ & $\begin{array}{c}03,03+\mathrm{h} \\
(11)\end{array}$ & $\begin{array}{c}04,04+\mathrm{h} \\
(12)\end{array}$ & $\begin{array}{c}05,05+\mathrm{h} \\
(13)\end{array}$ & $\begin{array}{c}06,06+h \\
(14)\end{array}$ & $\begin{array}{c}07,07+\mathrm{h} \\
(15)\end{array}$ & & & & \\
\hline \multicolumn{19}{|c|}{ A. With overlapping observations } \\
\hline 1 & $\begin{array}{c}69.84 \\
(49.02)\end{array}$ & $\begin{array}{c}0.86 \\
(6.38)\end{array}$ & $\begin{array}{l}-2.00 \\
(5.75)\end{array}$ & $\begin{array}{l}-9.89 \\
(4.12)\end{array}$ & $\begin{array}{c}17.82 \\
(24.57)\end{array}$ & $\begin{array}{l}-4.50 \\
(2.09)\end{array}$ & $\begin{array}{l}-10.14 \\
(3.80)\end{array}$ & $\begin{array}{l}-7.94 \\
(6.57)\end{array}$ & $\begin{array}{c}2.72 \\
(6.03)\end{array}$ & $\begin{array}{c}2.02 \\
(4.08)\end{array}$ & $\begin{array}{c}3.72 \\
(2.86)\end{array}$ & $\begin{array}{c}0.53 \\
(2.22)\end{array}$ & $\begin{array}{c}5.94 \\
(1.84)\end{array}$ & $\begin{array}{l}10.64 \\
(2.55)\end{array}$ & $\begin{array}{c}5.69 \\
(3.25)\end{array}$ & $\begin{array}{l}-0.31 \\
(0.37)\end{array}$ & 336 & 0.07 \\
\hline 2 & $\begin{array}{c}65.28 \\
(49.23)\end{array}$ & $\begin{array}{l}-5.80 \\
(9.06)\end{array}$ & $\begin{array}{r}-14.74 \\
(8.00)\end{array}$ & $\begin{array}{c}9.72 \\
(20.01)\end{array}$ & $\begin{array}{c}14.26 \\
(25.17)\end{array}$ & $\begin{array}{l}-12.09 \\
(2.68)\end{array}$ & $\begin{array}{r}-13.95 \\
(6.38)\end{array}$ & $\begin{array}{l}-1.33 \\
(9.02)\end{array}$ & $\begin{array}{l}7.58 \\
(7.95)\end{array}$ & $\begin{array}{c}8.37 \\
(4.59)\end{array}$ & $\begin{array}{c}6.06 \\
(3.93)\end{array}$ & $\begin{array}{c}6.66 \\
(3.16)\end{array}$ & $\begin{array}{l}16.45 \\
(3.07)\end{array}$ & & $\begin{array}{c}6.65 \\
(4.57)\end{array}$ & $\begin{array}{l}-0.29 \\
(0.51)\end{array}$ & 312 & 0.06 \\
\hline 3 & $\begin{array}{c}58.78 \\
(49.58)\end{array}$ & $\begin{array}{l}-18.47 \\
(11.52)\end{array}$ & $\begin{array}{c}4.88 \\
(15.93)\end{array}$ & $\begin{array}{c}6.01 \\
(18.48)\end{array}$ & $\begin{array}{c}6.67 \\
(26.38)\end{array}$ & $\begin{array}{l}-15.99 \\
(4.83)\end{array}$ & $\begin{array}{l}-7.46 \\
(8.23)\end{array}$ & $\begin{array}{c}3.46 \\
(11.08)\end{array}$ & $\begin{array}{l}13.89 \\
(8.85)\end{array}$ & $\begin{array}{l}10.66 \\
(5.81)\end{array}$ & $\begin{array}{l}12.17 \\
(5.20)\end{array}$ & $\begin{array}{l}17.20 \\
(4.52)\end{array}$ & & & $\begin{array}{c}7.65 \\
(6.56)\end{array}$ & $\begin{array}{l}-0.29 \\
(0.64)\end{array}$ & 288 & 0.05 \\
\hline 4 & $\begin{array}{c}47.67 \\
(49.93)\end{array}$ & $\begin{array}{c}3.62 \\
(15.02)\end{array}$ & $\begin{array}{c}3.21 \\
(15.82)\end{array}$ & $\begin{array}{c}-0.43 \\
(18.79)\end{array}$ & $\begin{array}{c}1.90 \\
(26.82)\end{array}$ & $\begin{array}{l}-9.95 \\
(5.53)\end{array}$ & $\begin{array}{l}-3.89 \\
(8.98)\end{array}$ & $\begin{array}{c}7.89 \\
(11.01)\end{array}$ & $\begin{array}{l}14.46 \\
(9.45)\end{array}$ & $\begin{array}{l}15.52 \\
(6.36)\end{array}$ & $\begin{array}{l}21.56 \\
(6.08)\end{array}$ & & & & $\begin{array}{c}9.23 \\
(8.80)\end{array}$ & $\begin{array}{l}-0.43 \\
(0.68)\end{array}$ & 264 & 0.03 \\
\hline 5 & $\begin{array}{c}67.69 \\
(47.86)\end{array}$ & $\begin{array}{c}0.45 \\
(13.80)\end{array}$ & $\begin{array}{c}-4.01 \\
(15.07)\end{array}$ & $\begin{array}{c}-4.11 \\
(17.86)\end{array}$ & $\begin{array}{c}8.16 \\
(27.53)\end{array}$ & $\begin{array}{l}-5.33 \\
(6.23)\end{array}$ & $\begin{array}{c}2.11 \\
(9.27)\end{array}$ & $\begin{array}{c}9.76 \\
(12.33)\end{array}$ & $\begin{array}{c}20.18 \\
(10.70)\end{array}$ & $\begin{array}{l}25.78 \\
(7.61)\end{array}$ & & & & & $\begin{array}{c}12.07 \\
(11.39)\end{array}$ & $\begin{array}{l}-0.45 \\
(0.78)\end{array}$ & 240 & 0.05 \\
\hline 6 & $\begin{array}{c}66.00 \\
(47.81)\end{array}$ & $\begin{array}{c}-3.96 \\
(13.95)\end{array}$ & $\begin{array}{c}-5.24 \\
(14.12)\end{array}$ & $\begin{array}{c}3.94 \\
(17.12)\end{array}$ & $\begin{array}{c}11.69 \\
(28.37)\end{array}$ & $\begin{array}{c}0.38 \\
(6.02)\end{array}$ & $\begin{array}{c}2.82 \\
(9.86)\end{array}$ & $\begin{array}{c}13.37 \\
(13.21)\end{array}$ & $\begin{array}{c}28.43 \\
(12.06)\end{array}$ & & & & & & $\begin{array}{c}13.05 \\
(12.16)\end{array}$ & $\begin{array}{l}-0.64 \\
(0.86)\end{array}$ & 216 & 0.05 \\
\hline 7 & $\begin{array}{c}61.67 \\
(48.63)\end{array}$ & $\begin{array}{c}-2.48 \\
(12.78)\end{array}$ & $\begin{array}{c}5.72 \\
(12.54)\end{array}$ & $\begin{array}{c}11.35 \\
(15.99)\end{array}$ & $\begin{array}{c}15.97 \\
(29.77)\end{array}$ & $\begin{array}{c}1.74 \\
(6.73)\end{array}$ & $\begin{array}{c}6.31 \\
(11.96)\end{array}$ & $\begin{array}{c}19.77 \\
(16.71)\end{array}$ & & & & & & & $\begin{array}{c}15.01 \\
(12.61)\end{array}$ & $\begin{array}{l}-0.95 \\
(1.11)\end{array}$ & 192 & 0.05 \\
\hline 8 & $\begin{array}{c}58.88 \\
(48.69)\end{array}$ & $\begin{array}{c}5.82 \\
(12.81)\end{array}$ & $\begin{array}{c}11.98 \\
(12.58)\end{array}$ & $\begin{array}{c}18.52 \\
(15.33)\end{array}$ & $\begin{array}{c}17.53 \\
(30.83)\end{array}$ & $\begin{array}{c}7.49 \\
(7.06)\end{array}$ & $\begin{array}{l}15.93 \\
(13.4)\end{array}$ & & & & & & & & $\begin{array}{c}19.45 \\
(13.23)\end{array}$ & $\begin{array}{l}-1.06 \\
(1.28)\end{array}$ & 168 & 0.04 \\
\hline 9 & $\begin{array}{c}63.98 \\
(48.36)\end{array}$ & $\begin{array}{c}8.32 \\
(12.67)\end{array}$ & $\begin{array}{c}16.37 \\
(12.16)\end{array}$ & $\begin{array}{c}19.64 \\
(14.48)\end{array}$ & $\begin{array}{c}24.37 \\
(31.64)\end{array}$ & $\begin{array}{l}18.35 \\
(7.80)\end{array}$ & & & & & & & & & $\begin{array}{c}25.17 \\
(14.50)\end{array}$ & $\begin{array}{l}-0.94 \\
(1.43)\end{array}$ & 144 & 0.03 \\
\hline 10 & $\begin{array}{c}67.60 \\
(48.56)\end{array}$ & $\begin{array}{c}12.80 \\
(13.30)\end{array}$ & $\begin{array}{c}17.13 \\
(12.11)\end{array}$ & $\begin{array}{c}24.82 \\
(13.89)\end{array}$ & $\begin{array}{c}35.51 \\
(32.21)\end{array}$ & & & & & & & & & & $\begin{array}{c}31.57 \\
(17.30)\end{array}$ & $\begin{array}{l}-0.83 \\
(1.53)\end{array}$ & 120 & 0.03 \\
\hline 11 & $\begin{array}{c}80.74 \\
(50.12)\end{array}$ & $\begin{array}{c}26.35 \\
(17.93)\end{array}$ & $\begin{array}{c}32.67 \\
(17.83)\end{array}$ & $\begin{array}{c}41.02 \\
(18.71)\end{array}$ & & & & & & & & & & & $\begin{array}{c}45.20 \\
(23.23)\end{array}$ & $\begin{array}{l}-1.49 \\
(1.26)\end{array}$ & 96 & 0.05 \\
\hline 12 & $\begin{array}{c}88.60 \\
(51.43)\end{array}$ & $\begin{array}{c}41.65 \\
(22.65)\end{array}$ & $\begin{array}{c}50.93 \\
(23.17)\end{array}$ & & & & & & & & & & & & $\begin{array}{c}60.39 \\
(29.96)\end{array}$ & $\begin{array}{c}-2.03 \\
(1.11)\end{array}$ & 72 & 0.07 \\
\hline 13 & $\begin{array}{l}102.82 \\
(54.39)\end{array}$ & $\begin{array}{c}65.55 \\
(30.42)\end{array}$ & & & & & & & & & & & & & $\begin{array}{c}84.19 \\
(40.16)\end{array}$ & $\begin{array}{l}-2.81 \\
(1.25)\end{array}$ & 48 & 0.11 \\
\hline 14 & $\begin{array}{l}135.62 \\
(62.56)\end{array}$ & & & & & & & & & & & & & & $\begin{array}{l}135.62 \\
(62.56)\end{array}$ & $\begin{array}{l}-4.94 \\
(2.25)\end{array}$ & 24 & 0.15 \\
\hline
\end{tabular}

TABLE A4 (continued)

(continued on next page) 
PREDICTIVE REGRESSIONS WITH TIME DUMMIES, CHANGES IN NOMINAL EXCHANGE RATES, 24 COUNTRIES, 1994-2008

$-\left(\mathrm{s}_{\mathrm{c}, \mathrm{t}+\mathrm{h}}-\mathrm{s}_{\mathrm{c}, \mathrm{t}}\right)=\sum_{\tau} \alpha_{\mathrm{s}, \tau, \tau+\mathrm{h}} \mathrm{D}_{\tau, \mathrm{t}}+\phi_{\mathrm{s}}^{\mathrm{h}} \mathrm{d}_{\mathrm{c}, \mathrm{t}}+\mathrm{u}_{\mathrm{s}, \mathrm{c}, \mathrm{t}}^{\mathrm{h}} \quad$ (Standard errors in parentheses)

\begin{tabular}{|c|c|c|c|c|c|c|c|c|c|c|c|c|c|c|c|c|c|c|}
\hline \multirow[b]{2}{*}{$\begin{array}{l}\mathrm{h} \\
\text { (1) } \\
\end{array}$} & \multicolumn{14}{|c|}{ Year dummies $\alpha_{s, \tau, \tau+h} \quad(\times 100)$} & \multirow{2}{*}{$\begin{array}{c}\eta^{\mathrm{h}}= \\
\left(1 / \mathrm{N}^{\mathrm{h}}\right) \sum_{\tau} \alpha_{\mathrm{s}, \tau, \tau+\mathrm{h}} \\
(\times 100) \\
(16)\end{array}$} & \multirow{2}{*}{$\begin{array}{l}\text { Slope } \\
\phi_{\mathrm{S}}^{\mathrm{h}} \\
(17)\end{array}$} & \multirow{2}{*}{$\begin{array}{c}\text { No. } \\
\text { of } \\
\text { Obs. } \\
(18)\end{array}$} & \multirow{2}{*}{$\begin{array}{l}\mathrm{R}^{2} \\
\text { (19) } \\
\end{array}$} \\
\hline & $\begin{array}{c}94,94+\mathrm{h} \\
(2)\end{array}$ & $\begin{array}{c}95,95+h \\
(3) \\
\end{array}$ & $\begin{array}{c}96,96+\mathrm{h} \\
(4) \\
\end{array}$ & $\begin{array}{c}97,97+h \\
(5) \\
\end{array}$ & $\begin{array}{c}98,98+h \\
(6) \\
\end{array}$ & $\begin{array}{c}99,99+h \\
(7) \\
\end{array}$ & $\begin{array}{c}00,00+\mathrm{h} \\
(8) \\
\end{array}$ & $\begin{array}{c}01,01+\mathrm{h} \\
(9) \\
\end{array}$ & $\begin{array}{c}02,02+\mathrm{h} \\
(10) \\
\end{array}$ & $\begin{array}{c}03,03+\mathrm{h} \\
(11)\end{array}$ & $\begin{array}{c}04,04+\mathrm{h} \\
(12) \\
\end{array}$ & $\begin{array}{c}05,05+h \\
(13)\end{array}$ & $\begin{array}{c}06,06+h \\
(14)\end{array}$ & $\begin{array}{c}07,07+\mathrm{h} \\
(15)\end{array}$ & & & & \\
\hline \multicolumn{19}{|c|}{ B. Without overlapping observations } \\
\hline 1 & $\begin{array}{c}69.84 \\
(49.02)\end{array}$ & $\begin{array}{c}0.86 \\
(6.38)\end{array}$ & $\begin{array}{l}-2.00 \\
(5.75)\end{array}$ & $\begin{array}{l}-9.89 \\
(4.12)\end{array}$ & $\begin{array}{c}17.82 \\
(24.57)\end{array}$ & $\begin{array}{l}-4.50 \\
(2.09)\end{array}$ & $\begin{array}{l}-10.14 \\
(3.80)\end{array}$ & $\begin{array}{l}-7.94 \\
(6.57)\end{array}$ & $\begin{array}{c}2.72 \\
(6.03)\end{array}$ & $\begin{array}{c}2.02 \\
(4.08)\end{array}$ & $\begin{array}{c}3.72 \\
(2.86)\end{array}$ & $\begin{array}{c}0.53 \\
(2.22)\end{array}$ & $\begin{array}{c}5.94 \\
(1.84)\end{array}$ & $\begin{array}{l}10.64 \\
(2.55)\end{array}$ & $\begin{array}{c}5.69 \\
(3.25)\end{array}$ & $\begin{array}{l}-0.31 \\
(0.37)\end{array}$ & 336 & 0.07 \\
\hline 2 & $\begin{array}{c}68.23 \\
(50.96)\end{array}$ & & $\begin{array}{l}-10.69 \\
(10.25)\end{array}$ & & $\begin{array}{c}12.52 \\
(25.83)\end{array}$ & & $\begin{array}{c}-16.24 \\
(6.99)\end{array}$ & & $\begin{array}{c}4.19 \\
(10.12)\end{array}$ & & $\begin{array}{c}3.77 \\
(5.32)\end{array}$ & & $\begin{array}{l}16.34 \\
(3.58)\end{array}$ & & $\begin{array}{l}11.16 \\
(6.41)\end{array}$ & $\begin{array}{l}-0.58 \\
(0.67)\end{array}$ & 168 & 0.07 \\
\hline 3 & $\begin{array}{c}71.96 \\
(53.54)\end{array}$ & & & $\begin{array}{c}16.89 \\
(21.41)\end{array}$ & & & $\begin{array}{c}-17.72 \\
(11.18)\end{array}$ & & & $\begin{array}{c}-0.28 \\
(10.51)\end{array}$ & & & & & $\begin{array}{c}17.71 \\
(11.21)\end{array}$ & $\begin{array}{l}-1.55 \\
(1.03)\end{array}$ & 96 & 0.07 \\
\hline 4 & $\begin{array}{c}54.19 \\
(54.93)\end{array}$ & & & & $\begin{array}{c}-1.95 \\
(28.88)\end{array}$ & & & & $\begin{array}{c}6.96 \\
(15.30)\end{array}$ & & & & & & $\begin{array}{c}19.73 \\
(14.41)\end{array}$ & $\begin{array}{l}-1.05 \\
(1.22)\end{array}$ & 72 & 0.03 \\
\hline 5 & $\begin{array}{c}95.48 \\
(58.57)\end{array}$ & & & & & $\begin{array}{c}-12.69 \\
(9.68)\end{array}$ & & & & & & & & & $\begin{array}{c}41.39 \\
(25.98)\end{array}$ & $\begin{array}{l}-3.11 \\
(1.69)\end{array}$ & 48 & 0.12 \\
\hline 6 & $\begin{array}{c}88.01 \\
(56.44)\end{array}$ & & & & & & $\begin{array}{l}-14.31 \\
(14.99)\end{array}$ & & & & & & & & $\begin{array}{c}36.85 \\
(22.80)\end{array}$ & $\begin{array}{l}-2.74 \\
(1.42)\end{array}$ & 48 & 0.10 \\
\hline 7 & $\begin{array}{c}83.34 \\
(56.70)\end{array}$ & & & & & & & $\begin{array}{c}-7.22 \\
(19.16)\end{array}$ & & & & & & & $\begin{array}{c}38.06 \\
(21.20)\end{array}$ & $\begin{array}{l}-3.02 \\
(1.47)\end{array}$ & 48 & 0.01 \\
\hline 8 & $\begin{array}{c}92.91 \\
(62.24)\end{array}$ & & & & & & & & & & & & & & $\begin{array}{c}92.91 \\
(62.24)\end{array}$ & $\begin{array}{l}-4.31 \\
(2.24)\end{array}$ & 24 & 0.12 \\
\hline 9 & $\begin{array}{c}99.31 \\
(60.23)\end{array}$ & & & & & & & & & & & & & & $\begin{array}{c}99.31 \\
(60.23)\end{array}$ & $\begin{array}{l}-4.31 \\
(2.15)\end{array}$ & 24 & 0.13 \\
\hline 10 & $\begin{array}{l}104.54 \\
(59.56)\end{array}$ & & & & & & & & & & & & & & $\begin{array}{l}104.54 \\
(59.56)\end{array}$ & $\begin{array}{l}-4.36 \\
(2.12)\end{array}$ & 24 & 0.13 \\
\hline 11 & $\begin{array}{l}112.14 \\
(60.56)\end{array}$ & & & & & & & & & & & & & & $\begin{array}{l}112.15 \\
(60.56)\end{array}$ & $\begin{array}{l}-4.49 \\
(2.18)\end{array}$ & 24 & 0.14 \\
\hline 12 & $\begin{array}{l}115.14 \\
(61.07)\end{array}$ & & & & & & & & & & & & & & $\begin{array}{l}115.14 \\
(61.07)\end{array}$ & $\begin{array}{l}-4.57 \\
(2.19)\end{array}$ & 24 & 0.14 \\
\hline 13 & $\begin{array}{l}123.58 \\
(61.37)\end{array}$ & & & & & & & & & & & & & & $\begin{array}{l}123.58 \\
(61.37)\end{array}$ & $\begin{array}{l}-4.79 \\
(2.20)\end{array}$ & 24 & 0.15 \\
\hline 14 & $\begin{array}{l}135.62 \\
(62.56)\end{array}$ & & & & & & & & & & & & & & $\begin{array}{l}135.62 \\
(62.56)\end{array}$ & $\begin{array}{l}-4.94 \\
(2.25)\end{array}$ & 24 & 0.15 \\
\hline
\end{tabular}

Note: Standard errors are robust, based on a cluster correction (Kleok, 1981). 
TABLE A5

PREDICTIVE REGRESSIONS WITH TIME DUMMIES, INFLATION DIFFERENTIALS, 24 COUNTRIES, 1994-2008

$$
r_{c, t+h}-r_{c, t}=\sum_{\tau} \alpha_{r, \tau, \tau+h} D_{\tau, t}+\phi_{r}^{h} d_{c, t}+u_{r, c, t}^{h}
$$

(Standard errors in parentheses)

\begin{tabular}{|c|c|c|c|c|c|c|c|c|c|c|c|c|c|c|c|c|c|c|}
\hline \multirow[b]{2}{*}{$\mathrm{h}$} & \multicolumn{14}{|c|}{ Year dummies $\alpha_{r, \tau, \tau+h} \quad(\times 100)$} & \multirow{2}{*}{$\begin{array}{c}\eta^{\mathrm{h}}= \\
\left(1 / \mathrm{N}^{\mathrm{h}}\right) \sum_{\tau} \alpha_{\mathrm{r}, \tau} \\
(\times 100) \\
(16)\end{array}$} & \multirow{2}{*}{$\begin{array}{l}\text { Slope } \\
\phi_{\mathrm{r}}^{\mathrm{h}} \\
(17)\end{array}$} & \multirow{2}{*}{$\begin{array}{c}\text { No. } \\
\text { of } \\
\text { Obs. } \\
\text { (18) }\end{array}$} & \multirow[b]{2}{*}{$\begin{array}{l}\mathrm{R}^{2} \\
\text { (19) }\end{array}$} \\
\hline & $94,94+\mathrm{h}$ & $95,95+h$ & $96,96+h$ & $97,97+h$ & $98,98+h$ & $99,99+h$ & $00,00+h$ & $01,01+\mathrm{h}$ & $02,02+\mathrm{h}$ & $03,03+h$ & $\begin{array}{c}04,04+h \\
(12)\end{array}$ & $\begin{array}{c}05,05+h \\
(13)\end{array}$ & $06,06+h$ & $07,07+h$ & & & & \\
\hline \multicolumn{19}{|c|}{ A. With overlapping observations } \\
\hline 1 & $\begin{array}{l}-59.54 \\
(48.22)\end{array}$ & $\begin{array}{c}2.26 \\
(6.40)\end{array}$ & $\begin{array}{c}1.20 \\
(5.68)\end{array}$ & $\begin{array}{l}-1.97 \\
(3.25)\end{array}$ & $\begin{array}{l}-16.54 \\
(25.56)\end{array}$ & $\begin{array}{l}-1.83 \\
(0.91)\end{array}$ & $\begin{array}{c}2.44 \\
(3.93)\end{array}$ & $\begin{array}{c}4.44 \\
(4.49)\end{array}$ & $\begin{array}{l}-3.50 \\
(5.17)\end{array}$ & $\begin{array}{l}-4.46 \\
(3.56)\end{array}$ & $\begin{array}{l}-3.92 \\
(3.50)\end{array}$ & $\begin{array}{c}2.72 \\
(2.26)\end{array}$ & $\begin{array}{l}-5.25 \\
(1.14)\end{array}$ & $\begin{array}{c}2.92 \\
(1.60)\end{array}$ & $\begin{array}{l}-5.79 \\
(3.09)\end{array}$ & $\begin{array}{l}-0.04 \\
(0.37)\end{array}$ & 336 & 0.05 \\
\hline 2 & $\begin{array}{l}-54.86 \\
(48.52)\end{array}$ & $\begin{array}{c}7.91 \\
(8.86)\end{array}$ & $\begin{array}{c}3.08 \\
(7.54)\end{array}$ & $\begin{array}{l}-15.78 \\
(20.49)\end{array}$ & $\begin{array}{l}-20.06 \\
(25.51)\end{array}$ & $\begin{array}{c}0.10 \\
(1.88)\end{array}$ & $\begin{array}{c}4.99 \\
(4.49)\end{array}$ & $\begin{array}{l}-2.41 \\
(6.95)\end{array}$ & $\begin{array}{c}-11.14 \\
(6.74)\end{array}$ & $\begin{array}{l}-10.60 \\
(4.95)\end{array}$ & $\begin{array}{l}-3.35 \\
(4.29)\end{array}$ & $\begin{array}{l}-4.12 \\
(3.16)\end{array}$ & $\begin{array}{l}-2.46 \\
(2.02)\end{array}$ & & $\begin{array}{l}-8.36 \\
(4.43)\end{array}$ & $\begin{array}{l}-0.33 \\
(0.49)\end{array}$ & 312 & 0.05 \\
\hline 3 & $\begin{array}{l}-51.44 \\
(49.30)\end{array}$ & $\begin{array}{c}10.14 \\
(11.39)\end{array}$ & $\begin{array}{c}-9.45 \\
(15.92)\end{array}$ & $\begin{array}{l}-15.24 \\
(18.40)\end{array}$ & $\begin{array}{l}-18.95 \\
(26.89)\end{array}$ & $\begin{array}{c}4.28 \\
(2.07)\end{array}$ & $\begin{array}{l}-0.22 \\
(6.50)\end{array}$ & $\begin{array}{l}-9.98 \\
(9.27)\end{array}$ & $\begin{array}{c}-17.93 \\
(8.69)\end{array}$ & $\begin{array}{l}-9.96 \\
(5.92)\end{array}$ & $\begin{array}{l}-10.73 \\
(5.23)\end{array}$ & $\begin{array}{l}-2.67 \\
(4.27)\end{array}$ & & & $\begin{array}{c}-11.01 \\
(6.51)\end{array}$ & $\begin{array}{l}-0.59 \\
(0.63)\end{array}$ & 288 & 0.05 \\
\hline 4 & $\begin{array}{c}-53.14 \\
(49.06)\end{array}$ & $\begin{array}{l}-5.22 \\
(14.7)\end{array}$ & $\begin{array}{c}-10.38 \\
(15.33)\end{array}$ & $\begin{array}{l}-12.02 \\
(18.95)\end{array}$ & $\begin{array}{l}-14.38 \\
(26.56)\end{array}$ & $\begin{array}{c}1.06 \\
(3.49)\end{array}$ & $\begin{array}{l}-4.81 \\
(7.08)\end{array}$ & $\begin{array}{l}-14.32 \\
(10.06)\end{array}$ & $\begin{array}{l}-15.67 \\
(8.91)\end{array}$ & $\begin{array}{c}-15.68 \\
(6.04)\end{array}$ & $\begin{array}{l}-8.27 \\
(5.52)\end{array}$ & & & & $\begin{array}{l}-13.89 \\
(8.82)\end{array}$ & $\begin{array}{c}-0.64 \\
(0.66)\end{array}$ & 264 & 0.04 \\
\hline 5 & $\begin{array}{c}-68.90 \\
(48.41)\end{array}$ & $\begin{array}{c}-6.04 \\
(13.06)\end{array}$ & $\begin{array}{c}-6.88 \\
(14.71)\end{array}$ & $\begin{array}{c}-6.66 \\
(17.88)\end{array}$ & $\begin{array}{l}-17.77 \\
(27.45)\end{array}$ & $\begin{array}{l}-3.23 \\
(4.28)\end{array}$ & $\begin{array}{l}-8.87 \\
(8.56)\end{array}$ & $\begin{array}{l}-12.09 \\
(12.17)\end{array}$ & $\begin{array}{c}-21.54 \\
(10.38)\end{array}$ & $\begin{array}{r}-13.23 \\
(7.23)\end{array}$ & & & & & $\begin{array}{c}-16.52 \\
(11.56)\end{array}$ & $\begin{array}{l}-0.70 \\
(0.77)\end{array}$ & 240 & 0.05 \\
\hline 6 & $\begin{array}{l}-70.83 \\
(48.74)\end{array}$ & $\begin{array}{c}-3.64 \\
(13.55)\end{array}$ & $\begin{array}{c}-2.25 \\
(14.49)\end{array}$ & $\begin{array}{c}-9.89 \\
(17.50)\end{array}$ & $\begin{array}{l}-21.80 \\
(27.97)\end{array}$ & $\begin{array}{l}-6.79 \\
(5.13)\end{array}$ & $\begin{array}{l}-5.78 \\
(9.79)\end{array}$ & $\begin{array}{l}-17.07 \\
(13.46)\end{array}$ & $\begin{array}{l}-18.41 \\
(11.49)\end{array}$ & & & & & & $\begin{array}{l}-17.38 \\
(12.28)\end{array}$ & $\begin{array}{l}-0.68 \\
(0.85)\end{array}$ & 216 & 0.05 \\
\hline 7 & $\begin{array}{l}-70.04 \\
(49.05)\end{array}$ & $\begin{array}{c}-1.92 \\
(14.49)\end{array}$ & $\begin{array}{c}-7.99 \\
(13.59)\end{array}$ & $\begin{array}{l}-15.64 \\
(16.42)\end{array}$ & $\begin{array}{l}-24.27 \\
(29.76)\end{array}$ & $\begin{array}{l}-3.36 \\
(6.79)\end{array}$ & $\begin{array}{c}-9.51 \\
(12.33)\end{array}$ & $\begin{array}{l}-11.75 \\
(17.36)\end{array}$ & & & & & & & $\begin{array}{l}-18.06 \\
(12.77)\end{array}$ & $\begin{array}{l}-0.49 \\
(1.12)\end{array}$ & 192 & 0.04 \\
\hline 8 & $\begin{array}{c}-64.92 \\
(50.11)\end{array}$ & $\begin{array}{c}-4.63 \\
(13.93)\end{array}$ & $\begin{array}{c}-11.84 \\
(13.47)\end{array}$ & $\begin{array}{l}-19.08 \\
(15.96)\end{array}$ & $\begin{array}{l}-21.47 \\
(30.39)\end{array}$ & $\begin{array}{l}-8.65 \\
(7.44)\end{array}$ & $\begin{array}{c}-6.77 \\
(13.72)\end{array}$ & & & & & & & & $\begin{array}{l}-19.62 \\
(13.47)\end{array}$ & $\begin{array}{l}-0.51 \\
(1.26)\end{array}$ & 168 & 0.03 \\
\hline 9 & $\begin{array}{l}-68.26 \\
(50.38)\end{array}$ & $\begin{array}{c}-9.24 \\
(15.12)\end{array}$ & $\begin{array}{c}-15.85 \\
(13.77)\end{array}$ & $\begin{array}{l}-16.39 \\
(14.81)\end{array}$ & $\begin{array}{c}-26.54 \\
(31.49)\end{array}$ & $\begin{array}{l}-5.67 \\
(8.50)\end{array}$ & & & & & & & & & $\begin{array}{l}-23.66 \\
(15.00)\end{array}$ & $\begin{array}{l}-0.49 \\
(1.46)\end{array}$ & 144 & 0.03 \\
\hline 10 & $\begin{array}{l}-72.35 \\
(50.83)\end{array}$ & $\begin{array}{c}-12.77 \\
(15.88)\end{array}$ & $\begin{array}{c}-12.85 \\
(13.56)\end{array}$ & $\begin{array}{c}-21.58 \\
(14.25)\end{array}$ & $\begin{array}{l}-23.67 \\
(32.11)\end{array}$ & & & & & & & & & & $\begin{array}{c}-28.64 \\
(18.00)\end{array}$ & $\begin{array}{l}-0.49 \\
(1.57)\end{array}$ & 120 & 0.03 \\
\hline 11 & $\begin{array}{l}-81.61 \\
(51.3)\end{array}$ & $\begin{array}{c}-19.09 \\
(18.93)\end{array}$ & $\begin{array}{c}-25.83 \\
(17.95)\end{array}$ & $\begin{array}{c}-23.33 \\
(18.19)\end{array}$ & & & & & & & & & & & $\begin{array}{l}-37.47 \\
(23.58)\end{array}$ & $\begin{array}{c}0.05 \\
(1.31)\end{array}$ & 96 & 0.03 \\
\hline 12 & $\begin{array}{l}-84.55 \\
(51.98)\end{array}$ & $\begin{array}{l}-33.93 \\
(23.21)\end{array}$ & $\begin{array}{c}-30.98 \\
(22.74)\end{array}$ & & & & & & & & & & & & $\begin{array}{l}-49.82 \\
(29.96)\end{array}$ & $\begin{array}{c}0.61 \\
(1.19)\end{array}$ & 72 & 0.03 \\
\hline 13 & $\begin{array}{l}-97.09 \\
(53.93)\end{array}$ & $\begin{array}{l}-43.01 \\
(29.52)\end{array}$ & & & & & & & & & & & & & $\begin{array}{l}-70.05 \\
(39.26)\end{array}$ & $\begin{array}{c}1.31 \\
(1.30)\end{array}$ & 48 & 0.05 \\
\hline 14 & $\begin{array}{c}-115.26 \\
(61.02)\end{array}$ & & & & & & & & & & & & & & $\begin{array}{c}-115.26 \\
(61.02)\end{array}$ & $\begin{array}{c}3.32 \\
(2.18)\end{array}$ & 24 & 0.08 \\
\hline
\end{tabular}

(continued on next page) 
TABLE A5 (continued)

PREDICTIVE REGRESSIONS WITH TIME DUMMIES, INFLATION DIFFERENTIALS, 24 COUNTRIES, 1994-2008

$$
\mathrm{r}_{\mathrm{c}, \mathrm{t}+\mathrm{h}}-\mathrm{r}_{\mathrm{c}, \mathrm{t}}=\sum_{\tau} \alpha_{\mathrm{r}, \tau, \tau+\mathrm{h}} \mathrm{D}_{\tau, \mathrm{t}}+\phi_{\mathrm{r}}^{\mathrm{h}} \mathrm{d}_{\mathrm{c}, \mathrm{t}}+\mathrm{u}_{\mathrm{r}, \mathrm{c}, \mathrm{t}}^{\mathrm{h}} \quad \text { (Standard errors in parentheses) }
$$

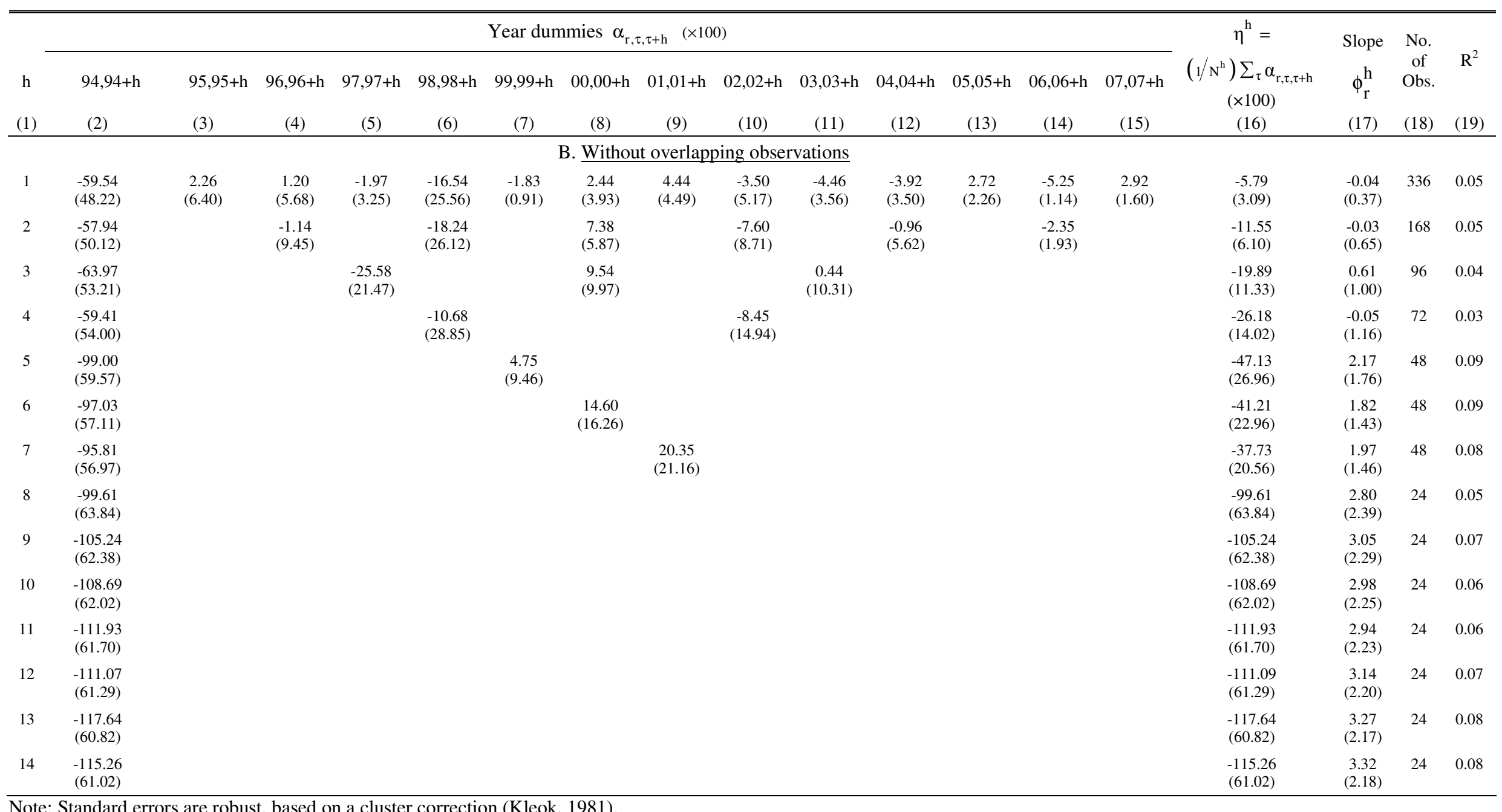

Note: Standard errors are robust, based on a cluster correction (Kleok, 1981). 
TABLE A6

SEEMINGLY UNRELATED REGRESSIONS UNDER FULL ADJUSTMENT WITH TIME DUMMIES, 24 COUNTRIES, 1994-2008

$$
-\left(\mathrm{s}_{\mathrm{c}, \mathrm{t}+\mathrm{H}}-\mathrm{s}_{\mathrm{c}, \mathrm{t}}\right)=\sum_{\tau} \alpha_{\mathrm{s}, \tau, \tau+\mathrm{H}} \mathrm{D}_{\tau, \mathrm{t}}+\phi_{\mathrm{s}}^{\mathrm{H}} \mathrm{d}_{\mathrm{c}, \mathrm{t}}+\mathrm{u}_{\mathrm{s}, \mathrm{c}, \mathrm{t}}^{\mathrm{H}} \text { and } \mathrm{r}_{\mathrm{c}, \mathrm{t}+\mathrm{H}}-\mathrm{r}_{\mathrm{c}, \mathrm{t}}=\sum_{\tau} \alpha_{\mathrm{r}, \tau, \tau+\mathrm{H}} \mathrm{D}_{\tau, \mathrm{t}}+\phi_{\mathrm{r}}^{\mathrm{H}} \mathrm{d}_{\mathrm{c}, \mathrm{t}}+\mathrm{u}_{\mathrm{r}, \mathrm{c}, \mathrm{t}}^{\mathrm{H}} \quad \text { with } \eta_{\mathrm{s}}^{\mathrm{H}}+\eta_{\mathrm{r}}^{\mathrm{H}}=0, \phi_{\mathrm{s}}^{\mathrm{H}}+\phi_{\mathrm{r}}^{\mathrm{H}}=-1
$$

(Standard errors in parentheses)

\begin{tabular}{|c|c|c|c|c|c|c|c|c|c|c|c|c|c|c|c|c|c|}
\hline \multirow[b]{2}{*}{$\begin{array}{l}\mathrm{H} \\
\text { (1) }\end{array}$} & \multicolumn{14}{|c|}{ Year dummies $\alpha_{\mathrm{s}, \tau, \tau+\mathrm{H}}(\times 100)$} & \multirow{2}{*}{$\begin{array}{c}\eta^{\mathrm{H}}= \\
\left(1 / \mathrm{N}^{\mathrm{H}}\right) \sum_{\tau} \alpha_{\mathrm{s}, \tau, \tau+\mathrm{H}} \\
(\times 100) \\
(16)\end{array}$} & \multirow{2}{*}{$\begin{array}{l}\text { Slope } \\
\phi_{\mathrm{S}}^{\mathrm{H}} \\
(17)\end{array}$} & \multirow{2}{*}{$\begin{array}{c}\text { No. } \\
\text { of } \\
\text { Obs } \\
(18)\end{array}$} \\
\hline & $\begin{array}{c}94,94+\mathrm{H} \\
(2)\end{array}$ & $\begin{array}{c}95,95+\mathrm{H} \\
(3)\end{array}$ & $\begin{array}{c}96,96+\mathrm{H} \\
(4)\end{array}$ & $\begin{array}{c}97,97+\mathrm{H} \\
(5)\end{array}$ & $\begin{array}{c}98,98+\mathrm{H} \\
(6)\end{array}$ & $\begin{array}{c}99,99+\mathrm{H} \\
(7)\end{array}$ & $\begin{array}{c}00,00+\mathrm{H} \\
(8)\end{array}$ & $\begin{array}{c}01,01+\mathrm{H} \\
(9)\end{array}$ & $\begin{array}{c}02,02+\mathrm{H} \\
(10)\end{array}$ & $\begin{array}{c}03,03+\mathrm{H} \\
(11)\end{array}$ & $\begin{array}{c}04,04+\mathrm{H} \\
(12)\end{array}$ & $\begin{array}{c}05,05+\mathrm{H} \\
(13)\end{array}$ & $\begin{array}{c}06,06+\mathrm{H} \\
(14)\end{array}$ & $\begin{array}{c}07,07+\mathrm{H} \\
(15)\end{array}$ & & & \\
\hline \multicolumn{18}{|c|}{ A. With overlapping observations } \\
\hline 1 & $\begin{array}{c}75.20 \\
(14.15)\end{array}$ & $\begin{array}{c}9.32 \\
(14.54)\end{array}$ & $\begin{array}{c}5.17 \\
(14.36)\end{array}$ & $\begin{array}{c}-5.37 \\
(14.08)\end{array}$ & $\begin{array}{c}15.49 \\
(14.00)\end{array}$ & $\begin{array}{c}-5.26 \\
(13.94)\end{array}$ & $\begin{array}{l}-13.37 \\
(14.06)\end{array}$ & $\begin{array}{l}-13.43 \\
(14.28)\end{array}$ & $\begin{array}{c}-2.32 \\
(14.23)\end{array}$ & $\begin{array}{c}-1.46 \\
(14.08)\end{array}$ & $\begin{array}{c}0.49 \\
(14.06)\end{array}$ & $\begin{array}{c}-1.50 \\
(13.99)\end{array}$ & $\begin{array}{c}6.29 \\
(13.92)\end{array}$ & $\begin{array}{c}11.37 \\
(13.92)\end{array}$ & $\begin{array}{c}5.76 \\
(3.73)\end{array}$ & $\begin{array}{l}-0.77 \\
(0.25)\end{array}$ & 336 \\
\hline 2 & $\begin{array}{c}70.22 \\
(16.05)\end{array}$ & $\begin{array}{c}1.21 \\
(16.53)\end{array}$ & $\begin{array}{c}-8.59 \\
(16.30)\end{array}$ & $\begin{array}{c}14.10 \\
(15.96)\end{array}$ & $\begin{array}{c}14.08 \\
(15.86)\end{array}$ & $\begin{array}{l}-11.22 \\
(15.78)\end{array}$ & $\begin{array}{l}-14.73 \\
(15.94)\end{array}$ & $\begin{array}{l}-3.62 \\
(16.21)\end{array}$ & $\begin{array}{c}5.59 \\
(16.14)\end{array}$ & $\begin{array}{c}7.42 \\
(15.96)\end{array}$ & $\begin{array}{c}5.28 \\
(15.94)\end{array}$ & $\begin{array}{c}6.67 \\
(15.84)\end{array}$ & $\begin{array}{c}18.05 \\
(15.76)\end{array}$ & & $\begin{array}{c}8.03 \\
(4.44)\end{array}$ & $\begin{array}{l}-0.60 \\
(0.29)\end{array}$ & 312 \\
\hline 3 & $\begin{array}{c}62.35 \\
(18.02)\end{array}$ & $\begin{array}{l}-14.27 \\
(18.58)\end{array}$ & $\begin{array}{c}8.82 \\
(18.32)\end{array}$ & $\begin{array}{c}9.41 \\
(17.91)\end{array}$ & $\begin{array}{c}8.71 \\
(17.80)\end{array}$ & $\begin{array}{l}-13.65 \\
(17.70)\end{array}$ & $\begin{array}{c}-5.61 \\
(17.89)\end{array}$ & $\begin{array}{c}4.86 \\
(18.20)\end{array}$ & $\begin{array}{c}15.38 \\
(18.13)\end{array}$ & $\begin{array}{c}12.46 \\
(17.91)\end{array}$ & $\begin{array}{c}14.03 \\
(17.89)\end{array}$ & $\begin{array}{c}19.29 \\
(17.78)\end{array}$ & & & $\begin{array}{l}10.15 \\
(5.20)\end{array}$ & $\begin{array}{l}-0.38 \\
(0.33)\end{array}$ & 288 \\
\hline 4 & $\begin{array}{c}51.74 \\
(20.17)\end{array}$ & $\begin{array}{c}7.21 \\
(20.84)\end{array}$ & $\begin{array}{c}7.00 \\
(20.52)\end{array}$ & $\begin{array}{c}3.77 \\
(20.05)\end{array}$ & $\begin{array}{c}7.16 \\
(19.91)\end{array}$ & $\begin{array}{c}-4.93 \\
(19.80)\end{array}$ & $\begin{array}{c}1.52 \\
(20.01)\end{array}$ & $\begin{array}{c}13.65 \\
(20.39)\end{array}$ & $\begin{array}{c}20.15 \\
(20.30)\end{array}$ & $\begin{array}{c}20.96 \\
(20.05)\end{array}$ & $\begin{array}{c}26.96 \\
(20.01)\end{array}$ & & & & $\begin{array}{l}14.11 \\
(6.09)\end{array}$ & $\begin{array}{l}-0.35 \\
(0.38)\end{array}$ & 264 \\
\hline 5 & $\begin{array}{c}68.92 \\
(21.41)\end{array}$ & $\begin{array}{c}1.26 \\
(22.19)\end{array}$ & $\begin{array}{c}-3.03 \\
(21.83)\end{array}$ & $\begin{array}{c}-2.77 \\
(21.26)\end{array}$ & $\begin{array}{c}10.44 \\
(21.11)\end{array}$ & $\begin{array}{c}-3.26 \\
(20.97)\end{array}$ & $\begin{array}{c}4.53 \\
(21.23)\end{array}$ & $\begin{array}{c}12.48 \\
(21.67)\end{array}$ & $\begin{array}{c}22.84 \\
(21.57)\end{array}$ & $\begin{array}{c}28.22 \\
(21.27)\end{array}$ & & & & & $\begin{array}{l}13.96 \\
(6.78)\end{array}$ & $\begin{array}{l}-0.39 \\
(0.43)\end{array}$ & 240 \\
\hline 6 & $\begin{array}{c}66.22 \\
(22.59)\end{array}$ & $\begin{array}{c}-4.10 \\
(23.48)\end{array}$ & $\begin{array}{c}-5.23 \\
(23.07)\end{array}$ & $\begin{array}{c}4.26 \\
(22.42)\end{array}$ & $\begin{array}{c}12.82 \\
(22.24)\end{array}$ & $\begin{array}{c}1.32 \\
(22.09)\end{array}$ & $\begin{array}{c}4.05 \\
(22.38)\end{array}$ & $\begin{array}{c}14.86 \\
(22.89)\end{array}$ & $\begin{array}{c}29.87 \\
(22.77)\end{array}$ & & & & & & $\begin{array}{l}13.76 \\
(7.55)\end{array}$ & $\begin{array}{l}-0.59 \\
(0.47)\end{array}$ & 216 \\
\hline 7 & $\begin{array}{c}61.63 \\
(24.08)\end{array}$ & $\begin{array}{c}-2.78 \\
(25.24)\end{array}$ & $\begin{array}{c}5.52 \\
(24.70)\end{array}$ & $\begin{array}{c}11.38 \\
(23.86)\end{array}$ & $\begin{array}{c}16.58 \\
(23.62)\end{array}$ & $\begin{array}{c}2.21 \\
(23.42)\end{array}$ & $\begin{array}{c}6.99 \\
(23.80)\end{array}$ & $\begin{array}{c}20.64 \\
(24.47)\end{array}$ & & & & & & & $\begin{array}{l}15.27 \\
(8.54)\end{array}$ & $\begin{array}{l}-0.92 \\
(0.56)\end{array}$ & 192 \\
\hline 8 & $\begin{array}{c}59.40 \\
(25.72)\end{array}$ & $\begin{array}{c}6.97 \\
(27.10)\end{array}$ & $\begin{array}{c}12.86 \\
(26.46)\end{array}$ & $\begin{array}{c}18.86 \\
(25.45)\end{array}$ & $\begin{array}{c}16.46 \\
(25.17)\end{array}$ & $\begin{array}{c}6.74 \\
(24.93)\end{array}$ & $\begin{array}{c}14.66 \\
(25.39)\end{array}$ & & & & & & & & $\begin{array}{l}19.42 \\
(9.73)\end{array}$ & $\begin{array}{l}-1.16 \\
(0.63)\end{array}$ & 168 \\
\hline 9 & $\begin{array}{c}65.88 \\
(27.56)\end{array}$ & $\begin{array}{c}12.02 \\
(29.23)\end{array}$ & $\begin{array}{c}19.32 \\
(28.46)\end{array}$ & $\begin{array}{c}21.06 \\
(27.24)\end{array}$ & $\begin{array}{c}21.82 \\
(26.89)\end{array}$ & $\begin{array}{c}16.71 \\
(26.60)\end{array}$ & & & & & & & & & $\begin{array}{c}26.13 \\
(11.29)\end{array}$ & $\begin{array}{l}-1.20 \\
(0.72)\end{array}$ & 144 \\
\hline 10 & $\begin{array}{c}70.13 \\
(30.09)\end{array}$ & $\begin{array}{c}16.91 \\
(32.05)\end{array}$ & $\begin{array}{c}20.58 \\
(31.13)\end{array}$ & $\begin{array}{l}26.91 \\
(29.7)\end{array}$ & $\begin{array}{c}34.07 \\
(29.29)\end{array}$ & & & & & & & & & & $\begin{array}{c}33.72 \\
(13.62)\end{array}$ & $\begin{array}{l}-1.07 \\
(0.81)\end{array}$ & 120 \\
\hline 11 & $\begin{array}{c}81.44 \\
(31.80)\end{array}$ & $\begin{array}{c}27.37 \\
(34.28)\end{array}$ & $\begin{array}{c}33.57 \\
(33.13)\end{array}$ & $\begin{array}{c}41.65 \\
(31.31)\end{array}$ & & & & & & & & & & & $\begin{array}{c}46.01 \\
(16.31)\end{array}$ & $\begin{array}{l}-1.54 \\
(0.94)\end{array}$ & 96 \\
\hline 12 & $\begin{array}{c}87.04 \\
(34.00)\end{array}$ & $\begin{array}{c}39.59 \\
(36.99)\end{array}$ & $\begin{array}{c}49.08 \\
(35.60)\end{array}$ & & & & & & & & & & & & $\begin{array}{c}58.57 \\
(20.51)\end{array}$ & $\begin{array}{l}-1.96 \\
(1.07)\end{array}$ & 72 \\
\hline 13 & $\begin{array}{c}92.43 \\
(38.20)\end{array}$ & $\begin{array}{c}52.32 \\
(42.29)\end{array}$ & & & & & & & & & & & & & $\begin{array}{c}72.38 \\
(28.46)\end{array}$ & $\begin{array}{l}-2.39 \\
(1.33)\end{array}$ & 48 \\
\hline 14 & $\begin{array}{c}94.84 \\
(49.41)\end{array}$ & & & & & & & & & & & & & & $\begin{array}{c}94.84 \\
(49.41)\end{array}$ & $\begin{array}{l}-3.69 \\
(2.31)\end{array}$ & 24 \\
\hline
\end{tabular}

(continued on next page) 
TABLE A6 (continued)

SEEMINGLY UNRELATED REGRESSIONS UNDER FULL ADJUSTMENT WITH TIME DUMMIES, 24 COUNTRIES, 1994-2008

$$
-\left(\mathrm{s}_{\mathrm{c}, \mathrm{t}+\mathrm{H}}-\mathrm{s}_{\mathrm{c}, \mathrm{t}}\right)=\sum_{\tau} \alpha_{\mathrm{s}, \tau, \tau+\mathrm{H}} \mathrm{D}_{\tau, \mathrm{t}}+\phi_{\mathrm{s}}^{\mathrm{H}} \mathrm{d}_{\mathrm{c}, \mathrm{t}}+\mathrm{u}_{\mathrm{s}, \mathrm{c}, \mathrm{t}}^{\mathrm{H}} \text { and } \mathrm{r}_{\mathrm{c}, \mathrm{t}+\mathrm{H}}-\mathrm{r}_{\mathrm{c}, \mathrm{t}}=\sum_{\tau} \alpha_{\mathrm{r}, \tau, \tau+\mathrm{H}} \mathrm{D}_{\tau, \mathrm{t}}+\phi_{\mathrm{r}}^{\mathrm{H}} \mathrm{d}_{\mathrm{c}, \mathrm{t}}+\mathrm{u}_{\mathrm{r}, \mathrm{c}, \mathrm{t}}^{\mathrm{H}} \quad \text { with } \eta_{\mathrm{s}}^{\mathrm{H}}+\eta_{\mathrm{r}}^{\mathrm{H}}=0, \phi_{\mathrm{s}}^{\mathrm{H}}+\phi_{\mathrm{r}}^{\mathrm{H}}=-1
$$

(Standard errors in parentheses)

\begin{tabular}{|c|c|c|c|c|c|c|c|c|c|c|c|c|c|c|c|c|c|}
\hline \multirow[b]{2}{*}{$\begin{array}{l}\mathrm{H} \\
\text { (1) }\end{array}$} & \multicolumn{14}{|c|}{ Year dummies $\alpha_{\mathrm{s}, \tau, \tau+\mathrm{H}}(\times 100)$} & \multirow{2}{*}{$\begin{array}{c}\eta^{\mathrm{H}}= \\
\left(1 / \mathrm{N}^{\mathrm{H}}\right) \sum_{\tau} \alpha_{\mathrm{s}, \tau, \tau+\mathrm{H}} \\
(\times 100) \\
(16)\end{array}$} & \multirow{2}{*}{$\begin{array}{l}\text { Slope } \\
\phi_{\mathrm{S}}^{\mathrm{h}} \\
(17)\end{array}$} & \multirow{2}{*}{$\begin{array}{c}\text { No. } \\
\text { of } \\
\text { Obs. } \\
\text { (18) }\end{array}$} \\
\hline & $\begin{array}{c}94,94+\mathrm{H} \\
(2)\end{array}$ & $\begin{array}{c}95,95+\mathrm{H} \\
(3) \\
\end{array}$ & $\begin{array}{c}96,96+\mathrm{H} \\
(4) \\
\end{array}$ & $\begin{array}{c}97,97+\mathrm{H} \\
(5)\end{array}$ & $\begin{array}{c}98,98+\mathrm{H} \\
(6) \\
\end{array}$ & $\begin{array}{c}99,99+\mathrm{H} \\
(7) \\
\end{array}$ & $\begin{array}{c}00,00+\mathrm{H} \\
(8)\end{array}$ & $\begin{array}{c}01,01+\mathrm{H} \\
(9) \\
\end{array}$ & $\begin{array}{c}02,02+\mathrm{H} \\
(10)\end{array}$ & $\begin{array}{c}03,03+\mathrm{H} \\
(11) \\
\end{array}$ & $\begin{array}{c}04,04+\mathrm{H} \\
(12) \\
\end{array}$ & $\begin{array}{c}05,05+\mathrm{H} \\
(13)\end{array}$ & $\begin{array}{c}06,06+\mathrm{H} \\
(14) \\
\end{array}$ & $\begin{array}{c}07,07+\mathrm{H} \\
(15) \\
\end{array}$ & & & \\
\hline \multicolumn{18}{|c|}{ B. Without overlapping observations } \\
\hline 1 & $\begin{array}{c}75.20 \\
(14.16)\end{array}$ & $\begin{array}{c}9.32 \\
(14.55)\end{array}$ & $\begin{array}{c}5.17 \\
(14.36)\end{array}$ & $\begin{array}{c}-5.37 \\
(14.08)\end{array}$ & $\begin{array}{c}15.49 \\
(14.00)\end{array}$ & $\begin{array}{c}-5.26 \\
(13.94)\end{array}$ & $\begin{array}{l}-13.37 \\
(14.06)\end{array}$ & $\begin{array}{c}-13.43 \\
(14.28)\end{array}$ & $\begin{array}{c}-2.32 \\
(14.23)\end{array}$ & $\begin{array}{c}-1.46 \\
(14.08)\end{array}$ & $\begin{array}{c}0.49 \\
(14.06)\end{array}$ & $\begin{array}{c}-1.50 \\
(13.99)\end{array}$ & $\begin{array}{c}6.29 \\
(13.92)\end{array}$ & $\begin{array}{c}11.37 \\
(13.92)\end{array}$ & $\begin{array}{c}5.76 \\
(3.77)\end{array}$ & $\begin{array}{l}-0.77 \\
(0.25)\end{array}$ & 336 \\
\hline 2 & $\begin{array}{c}73.05 \\
(19.98)\end{array}$ & & $\begin{array}{c}-4.40 \\
(20.49)\end{array}$ & & $\begin{array}{c}11.12 \\
(19.59)\end{array}$ & & $\begin{array}{l}-18.38 \\
(19.75)\end{array}$ & & $\begin{array}{c}0.59 \\
(20.17)\end{array}$ & & $\begin{array}{c}1.64 \\
(19.75)\end{array}$ & & $\begin{array}{c}17.11 \\
(19.39)\end{array}$ & & $\begin{array}{l}11.53 \\
(7.51)\end{array}$ & $\begin{array}{l}-0.95 \\
(0.46)\end{array}$ & 168 \\
\hline 3 & $\begin{array}{c}74.76 \\
(26.73)\end{array}$ & & & $\begin{array}{c}19.58 \\
(26.26)\end{array}$ & & & $\begin{array}{l}-16.09 \\
(26.15)\end{array}$ & & & $\begin{array}{c}1.32 \\
(26.27)\end{array}$ & & & & & $\begin{array}{c}19.89 \\
(13.17)\end{array}$ & $\begin{array}{l}-1.61 \\
(0.85)\end{array}$ & 96 \\
\hline 4 & $\begin{array}{c}62.00 \\
(30.80)\end{array}$ & & & & $\begin{array}{c}8.12 \\
(29.80)\end{array}$ & & & & $\begin{array}{c}17.83 \\
(31.28)\end{array}$ & & & & & & $\begin{array}{c}29.32 \\
(17.68)\end{array}$ & $\begin{array}{l}-0.91 \\
(0.92)\end{array}$ & 72 \\
\hline 5 & $\begin{array}{c}92.78 \\
(35.43)\end{array}$ & & & & & $\begin{array}{l}-14.98 \\
(32.10)\end{array}$ & & & & & & & & & $\begin{array}{c}38.90 \\
(15.92)\end{array}$ & $\begin{array}{l}-3.08 \\
(1.49)\end{array}$ & 48 \\
\hline 6 & $\begin{array}{c}81.57 \\
(34.66)\end{array}$ & & & & & & $\begin{array}{l}-18.82 \\
(33.52)\end{array}$ & & & & & & & & $\begin{array}{c}31.37 \\
(24.11)\end{array}$ & $\begin{array}{c}-2.64 \\
(1.34)\end{array}$ & 48 \\
\hline 7 & $\begin{array}{c}83.23 \\
(34.98)\end{array}$ & & & & & & & $\begin{array}{c}-7.18 \\
(36.56)\end{array}$ & & & & & & & $\begin{array}{c}38.03 \\
(25.29)\end{array}$ & $\begin{array}{l}-3.02 \\
(1.37)\end{array}$ & 48 \\
\hline 8 & $\begin{array}{c}84.01 \\
(49.70)\end{array}$ & & & & & & & & & & & & & & $\begin{array}{c}84.01 \\
(49.70)\end{array}$ & $\begin{array}{l}-4.99 \\
(2.33)\end{array}$ & 24 \\
\hline 9 & $\begin{array}{c}74.44 \\
(46.53)\end{array}$ & & & & & & & & & & & & & & $\begin{array}{c}74.44 \\
(46.53)\end{array}$ & $\begin{array}{l}-5.41 \\
(2.18)\end{array}$ & 24 \\
\hline 10 & $\begin{array}{c}85.92 \\
(45.67)\end{array}$ & & & & & & & & & & & & & & $\begin{array}{c}85.92 \\
(45.67)\end{array}$ & $\begin{array}{l}-6.07 \\
(2.14)\end{array}$ & 24 \\
\hline 11 & $\begin{array}{l}112.76 \\
(48.49)\end{array}$ & & & & & & & & & & & & & & $\begin{array}{l}112.76 \\
(48.49)\end{array}$ & $\begin{array}{l}-6.05 \\
(2.27)\end{array}$ & 24 \\
\hline 12 & $\begin{array}{l}119.41 \\
(49.69)\end{array}$ & & & & & & & & & & & & & & $\begin{array}{l}119.41 \\
(49.69)\end{array}$ & $\begin{array}{l}-5.01 \\
(2.32)\end{array}$ & 24 \\
\hline 13 & $\begin{array}{l}111.47 \\
(49.46)\end{array}$ & & & & & & & & & & & & & & $\begin{array}{l}111.47 \\
(49.46)\end{array}$ & $\begin{array}{l}-3.72 \\
(2.31)\end{array}$ & 24 \\
\hline 14 & $\begin{array}{c}94.84 \\
(49.41)\end{array}$ & & & & & & & & & & & & & & $\begin{array}{c}94.84 \\
(49.41)\end{array}$ & $\begin{array}{c}-3.69 \\
(2.31) \\
\end{array}$ & 24 \\
\hline
\end{tabular}


TABLE A7

MORE PREDICTIVE REGRESSIONS, 20 COUNTRIES (ARGENTINA, BRAZIL, POLAND, RUSSIA OMITTED), 1994-2008

(Standard errors in parentheses)

\begin{tabular}{|c|c|c|c|c|c|c|c|c|c|c|}
\hline \multirow[b]{2}{*}{$\begin{array}{l}\text { Horizon } \\
\mathrm{h} \\
(1)\end{array}$} & \multicolumn{5}{|c|}{$\begin{array}{l}\text { (i) Negative change in nominal exchange rate } \\
\qquad-\left(\mathrm{s}_{\mathrm{c}, \mathrm{t}+\mathrm{h}}-\mathrm{s}_{\mathrm{c}, \mathrm{t}}\right)=\eta_{\mathrm{s}}^{\mathrm{h}}+\phi_{\mathrm{s}}^{\mathrm{h}} \mathrm{d}_{\mathrm{ct}}+\mathrm{u}_{\mathrm{s}, \mathrm{ct}}^{\mathrm{h}}\end{array}$} & \multicolumn{5}{|c|}{$\begin{array}{l}\text { (ii) Inflation differential } \\
r_{c, t+h}-r_{c, t}=\eta_{r}^{h}+\phi_{r}^{h} d_{c t}^{h}+u_{r, c t}^{h}\end{array}$} \\
\hline & $\begin{array}{l}\text { Intercept } \\
\eta_{\mathrm{s}}^{\mathrm{h}} \times 100 \\
(2)\end{array}$ & $\begin{array}{l}\text { Slope } \\
\phi_{\mathrm{s}}^{\mathrm{h}} \\
(3)\end{array}$ & $\begin{array}{c}\text { No. of } \\
\text { observations } \\
\text { (4) }\end{array}$ & $\begin{array}{l}\mathrm{R}^{2} \\
(5)\end{array}$ & $\chi^{2}$ & $\begin{array}{l}\text { Intercept } \\
\eta_{\mathrm{r}}^{\mathrm{h}} \times 100 \\
(7)\end{array}$ & $\begin{array}{l}\text { Slope } \\
\phi_{\mathrm{r}}^{\mathrm{h}} \\
(8)\end{array}$ & $\begin{array}{c}\text { No. of } \\
\text { observations } \\
\text { (9) }\end{array}$ & $\begin{array}{l}\mathrm{R}^{2} \\
(10) \\
\end{array}$ & $\chi^{2}$ \\
\hline \multicolumn{11}{|c|}{ A. With overlapping observations } \\
\hline 1 & $0.31(0.66)$ & $\begin{array}{l}-0.15(0.04) \\
-0.15(0.04)\end{array}$ & 280 & 0.04 & 6.54 & $-0.49 \quad(0.43)$ & $\begin{array}{l}-0.13(0.03) \\
-0.13(0.03)\end{array}$ & 280 & 0.07 & 6.05 \\
\hline 2 & $-0.47(0.97)$ & $\begin{array}{l}-0.43(0.06) \\
-0.43(0.06)\end{array}$ & 260 & 0.15 & 8.57 & $-1.24 \quad(0.64)$ & $\begin{array}{l}-0.17(0.04) \\
-0.16(0.04)\end{array}$ & 260 & 0.06 & 3.67 \\
\hline 3 & $-1.47(1.19)$ & $\begin{array}{l}-0.72(0.08) \\
-0.71(0.08)\end{array}$ & 240 & 0.26 & $29.53^{*}$ & $-1.58 \quad(0.84)$ & $\begin{array}{l}-0.16(0.06) \\
-0.18(0.06)\end{array}$ & 240 & 0.04 & 0.09 \\
\hline 4 & $-2.04(1.41)$ & $\begin{array}{l}-0.96(0.09) \\
-0.95(0.09)\end{array}$ & 220 & 0.34 & $51.84^{*}$ & $-2.04 \quad(1.08)$ & $\begin{array}{l}-0.12(0.07) \\
-0.12(0.07)\end{array}$ & 220 & 0.01 & 0.19 \\
\hline 5 & $-1.57(1.60)$ & $\begin{array}{l}-1.13(0.10) \\
-1.13(0.10)\end{array}$ & 200 & 0.39 & $65.20^{*}$ & $-1.86(1.31)$ & $\begin{array}{l}-0.06(0.08) \\
-0.06(0.08)\end{array}$ & 200 & 0.00 & 2.81 \\
\hline 6 & $-1.25(1.76)$ & $\begin{array}{l}-1.30(0.11) \\
-1.30(0.11)\end{array}$ & 180 & 0.46 & $62.37 *$ & $-2.12(1.52)$ & $\begin{array}{l}-0.05(0.09) \\
-0.05(0.09)\end{array}$ & 180 & 0.00 & 1.57 \\
\hline 7 & $-1.08(1.83)$ & $\begin{array}{l}-1.33(0.11) \\
-1.34(0.11)\end{array}$ & 160 & 0.49 & $52.64^{*}$ & $-1.33(1.73)$ & $\begin{array}{l}-0.09(0.10) \\
-0.09(0.10)\end{array}$ & 160 & 0.01 & 3.39 \\
\hline 8 & $0.78(2.00)$ & $\begin{array}{l}-1.16(0.12) \\
-1.15(0.12)\end{array}$ & 140 & 0.40 & $41.05^{*}$ & $-0.72 \quad(2.00)$ & $\begin{array}{l}-0.28(0.12) \\
-0.29(0.12)\end{array}$ & 140 & 0.04 & 0.00 \\
\hline 9 & $2.72(2.30)$ & $\begin{array}{l}-1.00(0.14) \\
-0.95(0.13)\end{array}$ & 120 & 0.31 & $28.27 *$ & $-1.09 \quad(2.28)$ & $\begin{array}{l}-0.41(0.14) \\
-0.43(0.13)\end{array}$ & 120 & 0.07 & 0.03 \\
\hline 10 & $3.38(2.65)$ & $\begin{array}{l}-0.90(0.15) \\
-0.83(0.14)\end{array}$ & 100 & 0.27 & $10.52 *$ & $0.21 \quad(2.67)$ & $\begin{array}{l}-0.58(0.15) \\
-0.57(0.14)\end{array}$ & 100 & 0.13 & 2.56 \\
\hline 11 & $3.12(3.66)$ & $\begin{array}{l}-0.66(0.20) \\
-0.56(0.16)\end{array}$ & 80 & 0.12 & 1.92 & $4.82 \quad(3.59)$ & $\begin{array}{l}-0.92(0.20) \\
-0.77(0.16)\end{array}$ & 80 & 0.22 & 4.03 \\
\hline 12 & $3.45(4.59)$ & $\begin{array}{l}-0.58(0.23) \\
-0.47(0.18)\end{array}$ & 60 & 0.10 & 1.62 & $7.18 \quad(4.49)$ & $\begin{array}{l}-1.03(0.22) \\
-0.81(0.18)\end{array}$ & 60 & 0.27 & 2.38 \\
\hline 13 & $6.57(5.96)$ & $\begin{array}{l}-0.59(0.27) \\
-0.41(0.22)\end{array}$ & 40 & 0.11 & 0.23 & $5.21 \quad(5.99)$ & $\begin{array}{l}-0.97(0.27) \\
-0.82(0.22)\end{array}$ & 40 & 0.25 & 1.91 \\
\hline
\end{tabular}


TABLE A7 (continued)

MORE PREDICTIVE REGRESSIONS, 20 COUNTRIES (ARGENTINA, BRAZIL, POLAND, RUSSIA OMITTED), 1994-2008

(Standard errors in parentheses)

(i) Negative change in nominal exchange rate

(ii) Inflation differential

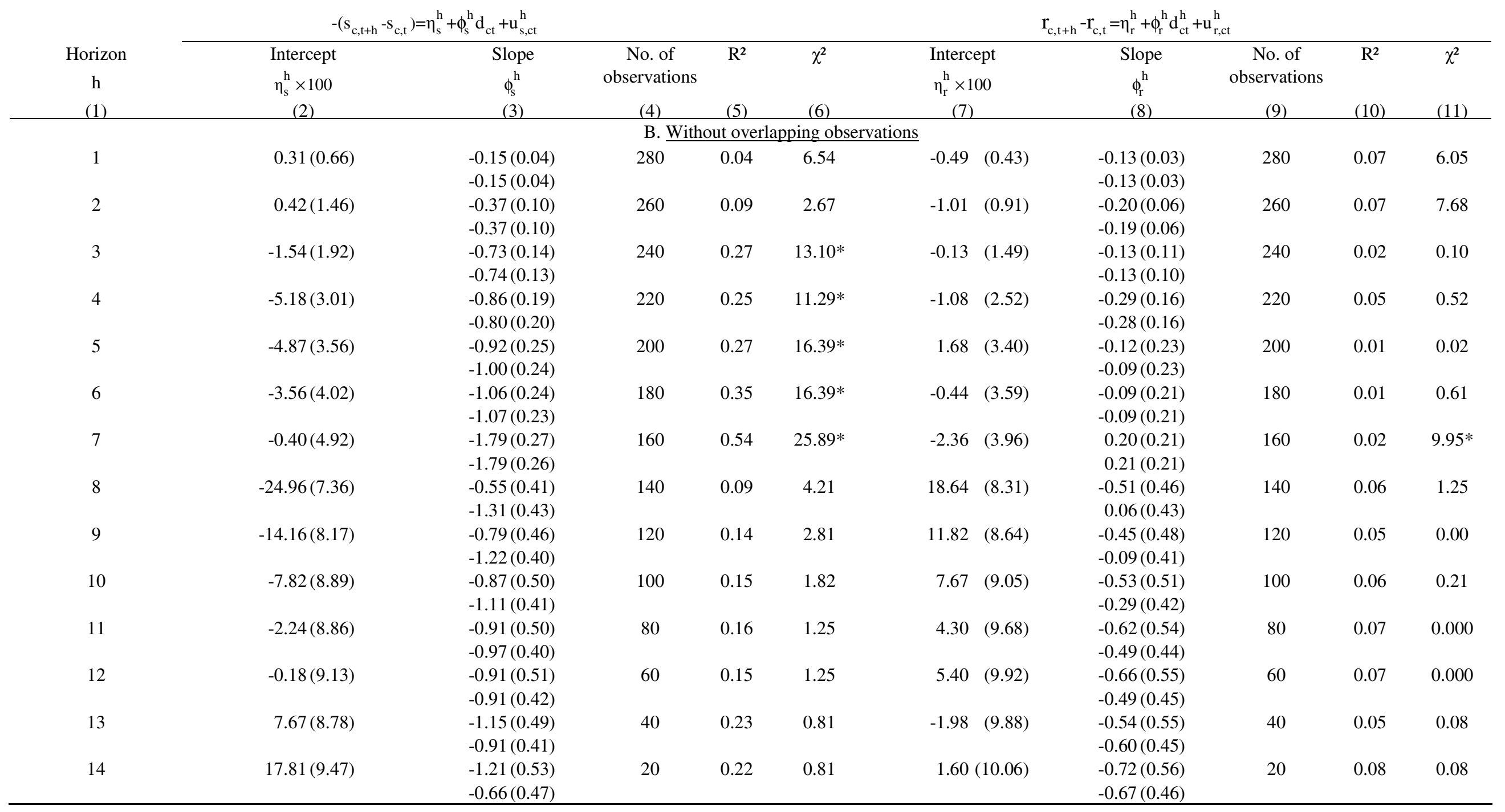

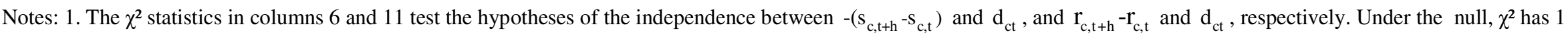
degree of freedom.

2. An asterisk (*) indicates significant at the 5 percent level. 
TABLE A8

SEEMINGLY UNRELATED REGRESSIONS UNDER FULL ADJUSTMENT,

20 COUNTRIES (ARGENTINA, BRAZIL, POLAND, RUSSIA OMITTED), 1994-2008

\begin{tabular}{|c|c|c|c|c|c|c|}
\hline \multirow[b]{2}{*}{$\begin{array}{c}\text { Horizon } \\
\qquad \begin{array}{c}\mathrm{H} \\
(1)\end{array}\end{array}$} & \multicolumn{3}{|c|}{ With overlapping observations } & \multicolumn{3}{|c|}{ Without overlapping observations } \\
\hline & $\begin{array}{c}\text { Intercept } \\
\eta_{\mathrm{s}}^{\mathrm{H}} \times 100 \\
\text { (2) }\end{array}$ & $\begin{array}{c}\text { Slope } \\
\phi_{\mathrm{s}}^{\mathrm{H}} \\
(3)\end{array}$ & $\begin{array}{c}\text { No. of } \\
\text { observations } \\
\text { (4) }\end{array}$ & $\begin{array}{l}\text { Intercept } \\
\eta_{\mathrm{s}}^{\mathrm{H}} \times 100 \\
\quad\end{array}$ & $\begin{array}{c}\text { Slope } \\
\phi_{s}^{\mathrm{H}} \\
(6)\end{array}$ & $\begin{array}{c}\text { No. of } \\
\text { observations } \\
\text { (7) }\end{array}$ \\
\hline 1 & $0.40(0.45)$ & $\begin{array}{l}-0.51(0.03) \\
-0.51(0.03)\end{array}$ & 280 & $0.40(0.45)$ & $\begin{array}{l}-0.51(0.03) \\
-0.51(0.03)\end{array}$ & 280 \\
\hline 2 & $0.39(0.60)$ & $\begin{array}{l}-0.63(0.04) \\
-0.63(0.04)\end{array}$ & 260 & $0.72(0.88)$ & $\begin{array}{l}-0.59(0.06) \\
-0.59(0.06)\end{array}$ & 140 \\
\hline 3 & $0.05(0.73)$ & $\begin{array}{l}-0.78(0.05) \\
-0.78(0.05)\end{array}$ & 240 & $-0.71(1.21)$ & $\begin{array}{l}-0.80(0.09) \\
-0.80(0.09)\end{array}$ & 80 \\
\hline 4 & $0.00(0.89)$ & $\begin{array}{l}-0.92(0.06) \\
-0.92(0.06)\end{array}$ & 220 & $-2.05(1.97)$ & $\begin{array}{l}-0.78(0.13) \\
-0.76(0.13)\end{array}$ & 60 \\
\hline 5 & $0.15(1.04)$ & $\begin{array}{l}-1.04(0.07) \\
-1.04(0.07)\end{array}$ & 200 & $-3.28(2.44)$ & $\begin{array}{l}-0.90(0.17) \\
-0.96(0.16)\end{array}$ & 40 \\
\hline 6 & $0.44(1.17)$ & $\begin{array}{l}-1.13(0.07) \\
-1.13(0.07)\end{array}$ & 180 & $-1.56(2.67)$ & $\begin{array}{l}-0.98(0.16) \\
-0.99(0.16)\end{array}$ & 40 \\
\hline 7 & $0.13(1.27)$ & $\begin{array}{l}-1.12(0.08) \\
-1.12(0.08)\end{array}$ & 160 & $0.98(3.18)$ & $\begin{array}{l}-1.50(0.17) \\
-1.50(0.17)\end{array}$ & 40 \\
\hline 8 & $0.75(1.43)$ & $\begin{array}{l}-0.94(0.09) \\
-0.93(0.08)\end{array}$ & 140 & $-21.80(5.44)$ & $\begin{array}{l}-0.52(0.30) \\
-1.19(0.30)\end{array}$ & 20 \\
\hline 9 & $1.90(1.63)$ & $\begin{array}{l}-0.80(0.10) \\
-0.71(0.02)\end{array}$ & 120 & $-12.99(5.81)$ & $\begin{array}{l}-0.67(0.33) \\
-1.67(0.29)\end{array}$ & 20 \\
\hline 10 & $1.59(1.90)$ & $\begin{array}{l}-0.66(0.11) \\
-0.63(0.10)\end{array}$ & 100 & $-7.75(6.21)$ & $\begin{array}{l}-0.67(0.35) \\
-0.91(0.29)\end{array}$ & 20 \\
\hline 11 & $-0.85(2.59)$ & $\begin{array}{l}-0.37(0.14) \\
-0.40(0.11)\end{array}$ & 80 & $-3.27(6.44)$ & $\begin{array}{l}-0.64(0.36) \\
-0.74(0.30)\end{array}$ & 20 \\
\hline 12 & $-1.87(3.24)$ & $\begin{array}{l}-0.27(0.16) \\
-0.33(0.13)\end{array}$ & 60 & $-2.79(6.61)$ & $\begin{array}{l}-0.63(0.37) \\
-0.71(0.31)\end{array}$ & 20 \\
\hline 13 & $0.68(4.24)$ & $\begin{array}{l}-0.31(0.20) \\
-0.29(0.16)\end{array}$ & 40 & $4.83(6.51)$ & $\begin{array}{l}-0.80(0.36) \\
-0.65(0.30)\end{array}$ & 20 \\
\hline 14 & $8.10(6.93)$ & $\begin{array}{l}-0.74(0.39) \\
-0.50(0.33)\end{array}$ & 20 & $8.10(6.93)$ & $\begin{array}{l}-0.74(0.39) \\
-0.50(0.33)\end{array}$ & 20 \\
\hline
\end{tabular}


TABLE A9

PREDICTIVE REGRESSIONS WITH TIME DUMMIES, CHANGES IN NOMINAL EXCHANGE RATES,

\section{COUNTRIES (ARGENTINA, BRAZIL, POLAND, RUSSIA OMITTED), 1994-2008}

$-\left(\mathrm{s}_{\mathrm{c}, \mathrm{t}+\mathrm{h}}-\mathrm{s}_{\mathrm{c}, \mathrm{t}}\right)=\sum_{\tau} \alpha_{\mathrm{s}, \tau, \tau+\mathrm{h}} \mathrm{D}_{\tau, \mathrm{t}}+\phi_{\mathrm{s}}^{\mathrm{h}} \mathrm{d}_{\mathrm{c}, \mathrm{t}}+\mathrm{u}_{\mathrm{s}, \mathrm{c}, \mathrm{t}}^{\mathrm{h}} \quad$ (Standard errors in parentheses)

\begin{tabular}{|c|c|c|c|c|c|c|c|c|c|c|c|c|c|c|c|c|c|c|}
\hline \multirow[b]{2}{*}{$\mathrm{h}$} & \multicolumn{14}{|c|}{ Year dummies $\alpha_{\mathrm{s}, \tau, \tau+h}(\times 100)$} & \multirow{2}{*}{$\begin{array}{c}\eta^{\mathrm{h}}= \\
\left(1 / \mathrm{N}^{\mathrm{h}}\right) \sum_{\tau} \alpha_{\mathrm{s}, \tau, \tau+1} \\
(\times 100) \\
(16)\end{array}$} & \multirow{2}{*}{$\begin{array}{l}\text { Slope } \\
\phi_{\mathrm{S}}^{\mathrm{h}} \\
\text { (17) }\end{array}$} & \multirow{2}{*}{$\begin{array}{c}\text { No. } \\
\text { of } \\
\text { Obs. }\end{array}$} & \multirow{2}{*}{$\begin{array}{l}\mathrm{R}^{2} \\
\text { (19) }\end{array}$} \\
\hline & $\begin{array}{c}94,94+h \\
(2)\end{array}$ & $\begin{array}{c}95,95+\mathrm{h} \\
(3)\end{array}$ & $\begin{array}{c}96,96+h \\
(4)\end{array}$ & $\begin{array}{c}97,97+h \\
(5)\end{array}$ & $\begin{array}{c}98,98+h \\
(6)\end{array}$ & $\begin{array}{c}99,99+h \\
(7)\end{array}$ & $\begin{array}{c}00,00+\mathrm{h} \\
(8)\end{array}$ & $\begin{array}{c}01,01+\mathrm{h} \\
(9)\end{array}$ & $\begin{array}{c}02,02+\mathrm{h} \\
(10)\end{array}$ & $\begin{array}{c}03,03+\mathrm{h} \\
(11)\end{array}$ & $\begin{array}{c}04,04+\mathrm{h} \\
(12)\end{array}$ & $\begin{array}{c}05,05+\mathrm{h} \\
(13)\end{array}$ & $\begin{array}{c}06,06+h \\
(14)\end{array}$ & $\begin{array}{c}07,07+\mathrm{h} \\
(15)\end{array}$ & & & & \\
\hline \multicolumn{19}{|c|}{ A. With overlapping observations } \\
\hline 1 & $\begin{array}{c}5.55 \\
(4.15)\end{array}$ & $\begin{array}{l}-2.52 \\
(2.52)\end{array}$ & $\begin{array}{l}-4.50 \\
(2.04)\end{array}$ & $\begin{array}{l}-13.17 \\
(3.14)\end{array}$ & $\begin{array}{l}-2.17 \\
(1.43)\end{array}$ & $\begin{array}{l}-3.39 \\
(1.89)\end{array}$ & $\begin{array}{l}-9.28 \\
(1.63)\end{array}$ & $\begin{array}{c}0.22 \\
(1.53)\end{array}$ & $\begin{array}{c}7.69 \\
(2.30)\end{array}$ & $\begin{array}{c}5.00 \\
(1.20)\end{array}$ & $\begin{array}{c}4.81 \\
(1.12)\end{array}$ & $\begin{array}{c}1.71 \\
(1.22)\end{array}$ & $\begin{array}{c}5.47 \\
(1.62)\end{array}$ & $\begin{array}{c}9.42 \\
(2.30)\end{array}$ & $\begin{array}{c}0.35 \\
(0.59)\end{array}$ & $\begin{array}{l}-0.11 \\
(0.07)\end{array}$ & 280 & 0.36 \\
\hline 2 & $\begin{array}{c}2.99 \\
(5.09)\end{array}$ & $\begin{array}{l}-5.48 \\
(4.01)\end{array}$ & $\begin{array}{r}-16.35 \\
(3.98)\end{array}$ & $\begin{array}{r}-12.99 \\
(3.00)\end{array}$ & $\begin{array}{l}-7.12 \\
(2.46)\end{array}$ & $\begin{array}{l}-12.25 \\
(2.38)\end{array}$ & $\begin{array}{l}-8.96 \\
(1.92)\end{array}$ & $\begin{array}{c}6.28 \\
(3.41)\end{array}$ & $\begin{array}{l}11.98 \\
(2.99)\end{array}$ & $\begin{array}{c}9.43 \\
(1.84)\end{array}$ & $\begin{array}{c}6.14 \\
(1.54)\end{array}$ & $\begin{array}{c}6.67 \\
(2.03)\end{array}$ & $\begin{array}{l}14.95 \\
(3.09)\end{array}$ & & $\begin{array}{l}-0.36 \\
(0.95)\end{array}$ & $\begin{array}{l}-0.29 \\
(0.12)\end{array}$ & 260 & 0.49 \\
\hline 3 & $\begin{array}{l}-1.18 \\
(5.66)\end{array}$ & $\begin{array}{r}-16.73 \\
(5.38)\end{array}$ & $\begin{array}{r}-15.41 \\
(4.26)\end{array}$ & $\begin{array}{c}-14.96 \\
(3.76)\end{array}$ & $\begin{array}{c}-17.25 \\
(2.55)\end{array}$ & $\begin{array}{c}-10.96 \\
(2.07)\end{array}$ & $\begin{array}{l}-1.83 \\
(2.74)\end{array}$ & $\begin{array}{c}9.54 \\
(4.00)\end{array}$ & $\begin{array}{c}16.09 \\
(3.20)\end{array}$ & $\begin{array}{l}10.70 \\
(2.20)\end{array}$ & $\begin{array}{l}10.97 \\
(2.57)\end{array}$ & $\begin{array}{l}15.69 \\
(3.61)\end{array}$ & & & $\begin{array}{l}-1.28 \\
(1.31)\end{array}$ & $\begin{array}{l}-0.45 \\
(0.15)\end{array}$ & 240 & 0.59 \\
\hline 4 & $\begin{array}{c}-14.08 \\
(6.34)\end{array}$ & $\begin{array}{l}-16.07 \\
(5.99)\end{array}$ & $\begin{array}{l}-17.29 \\
(5.27)\end{array}$ & $\begin{array}{l}-22.66 \\
(4.18)\end{array}$ & $\begin{array}{c}-16.62 \\
(2.43)\end{array}$ & $\begin{array}{l}-2.78 \\
(1.99)\end{array}$ & $\begin{array}{c}2.85 \\
(3.07)\end{array}$ & $\begin{array}{l}13.37 \\
(4.42)\end{array}$ & $\begin{array}{c}17.42 \\
(3.15)\end{array}$ & $\begin{array}{c}15.72 \\
(2.94)\end{array}$ & $\begin{array}{l}20.09 \\
(3.78)\end{array}$ & & & & $\begin{array}{l}-1.82 \\
(1.74)\end{array}$ & $\begin{array}{c}-0.56 \\
(0.2)\end{array}$ & 220 & 0.65 \\
\hline 5 & $\begin{array}{c}-14.48 \\
(6.65)\end{array}$ & $\begin{array}{r}-18.18 \\
(6.70)\end{array}$ & $\begin{array}{c}-24.96 \\
(5.85)\end{array}$ & $\begin{array}{l}-20.51 \\
(3.65)\end{array}$ & $\begin{array}{l}-8.81 \\
(3.27)\end{array}$ & $\begin{array}{c}2.57 \\
(2.31)\end{array}$ & $\begin{array}{c}7.61 \\
(3.34)\end{array}$ & $\begin{array}{l}14.58 \\
(4.59)\end{array}$ & $\begin{array}{l}22.49 \\
(3.81)\end{array}$ & $\begin{array}{l}24.96 \\
(4.05)\end{array}$ & & & & & $\begin{array}{l}-1.47 \\
(2.14)\end{array}$ & $\begin{array}{l}-0.62 \\
(0.24)\end{array}$ & 200 & 0.68 \\
\hline 6 & $\begin{array}{l}-16.55 \\
(7.08)\end{array}$ & $\begin{array}{l}-24.88 \\
(7.05)\end{array}$ & $\begin{array}{l}-22.00 \\
(5.53)\end{array}$ & $\begin{array}{l}-11.34 \\
(3.57)\end{array}$ & $\begin{array}{l}-4.41 \\
(3.61)\end{array}$ & $\begin{array}{l}7.55 \\
(2.58)\end{array}$ & $\begin{array}{c}8.82 \\
(3.12)\end{array}$ & $\begin{array}{l}18.64 \\
(4.85)\end{array}$ & $\begin{array}{l}31.29 \\
(4.75)\end{array}$ & & & & & & $\begin{array}{l}-1.43 \\
(2.54)\end{array}$ & $\begin{array}{l}-0.73 \\
(0.25)\end{array}$ & 180 & 0.69 \\
\hline 7 & $\begin{array}{c}-24.49 \\
(7.22)\end{array}$ & $\begin{array}{r}-22.41 \\
(6.55)\end{array}$ & $\begin{array}{l}-13.00 \\
(5.19)\end{array}$ & $\begin{array}{c}-5.52 \\
(3.95)\end{array}$ & $\begin{array}{c}0.37 \\
(3.39)\end{array}$ & $\begin{array}{c}9.48 \\
(2.56)\end{array}$ & $\begin{array}{l}13.95 \\
(3.05)\end{array}$ & $\begin{array}{l}27.55 \\
(5.39)\end{array}$ & & & & & & & $\begin{array}{l}-1.76 \\
(3.01)\end{array}$ & $\begin{array}{l}-0.77 \\
(0.23)\end{array}$ & 160 & 0.69 \\
\hline 8 & $\begin{array}{r}-23.17 \\
(7.01)\end{array}$ & $\begin{array}{r}-14.61 \\
(6.69)\end{array}$ & $\begin{array}{l}-7.97 \\
(5.51)\end{array}$ & $\begin{array}{c}-0.54 \\
(4.11)\end{array}$ & $\begin{array}{c}2.84 \\
(2.89)\end{array}$ & $\begin{array}{l}15.08 \\
(2.65)\end{array}$ & $\begin{array}{l}23.81 \\
(4.24)\end{array}$ & & & & & & & & $\begin{array}{c}-0.65 \\
(3.71)\end{array}$ & $\begin{array}{l}-0.73 \\
(0.24)\end{array}$ & 140 & 0.61 \\
\hline 9 & $\begin{array}{r}-15.63 \\
(7.64)\end{array}$ & $\begin{array}{r}-10.60 \\
(7.34)\end{array}$ & $\begin{array}{l}-3.81 \\
(5.67)\end{array}$ & $\begin{array}{c}0.88 \\
(4.57)\end{array}$ & $\begin{array}{c}9.32 \\
(3.08)\end{array}$ & $\begin{array}{l}24.86 \\
(3.84)\end{array}$ & & & & & & & & & $\begin{array}{c}0.84 \\
(4.57)\end{array}$ & $\begin{array}{l}-0.64 \\
(0.27)\end{array}$ & 120 & 0.49 \\
\hline 10 & $\begin{array}{c}-10.71 \\
(8.22)\end{array}$ & $\begin{array}{c}-6.32 \\
(7.30)\end{array}$ & $\begin{array}{c}-2.47 \\
(6.00)\end{array}$ & $\begin{array}{c}5.97 \\
(4.60)\end{array}$ & $\begin{array}{l}19.49 \\
(4.55)\end{array}$ & & & & & & & & & & $\begin{array}{c}1.19 \\
(5.28)\end{array}$ & $\begin{array}{l}-0.58 \\
(0.27)\end{array}$ & 100 & 0.38 \\
\hline 11 & $\begin{array}{l}-5.56 \\
(8.55)\end{array}$ & $\begin{array}{c}-4.43 \\
(8.13)\end{array}$ & $\begin{array}{c}2.91 \\
(6.43)\end{array}$ & $\begin{array}{c}15.43 \\
(5.55)\end{array}$ & & & & & & & & & & & $\begin{array}{c}2.09 \\
(6.81)\end{array}$ & $\begin{array}{l}-0.57 \\
(0.29)\end{array}$ & 80 & 0.21 \\
\hline 12 & $\begin{array}{l}-3.37 \\
(8.60)\end{array}$ & $\begin{array}{c}1.29 \\
(7.69)\end{array}$ & $\begin{array}{l}12.61 \\
(6.45)\end{array}$ & & & & & & & & & & & & $\begin{array}{c}3.51 \\
(7.33)\end{array}$ & $\begin{array}{l}-0.58 \\
(0.23)\end{array}$ & 60 & 0.15 \\
\hline 13 & $\begin{array}{c}2.65 \\
(8.29)\end{array}$ & $\begin{array}{c}11.67 \\
(7.58)\end{array}$ & & & & & & & & & & & & & $\begin{array}{c}7.16 \\
(7.82)\end{array}$ & $\begin{array}{l}-0.63 \\
(0.21)\end{array}$ & 40 & 0.13 \\
\hline 14 & $\begin{array}{l}17.81 \\
(7.26)\end{array}$ & & & & & & & & & & & & & & $\begin{array}{l}17.81 \\
(7.26)\end{array}$ & $\begin{array}{l}-1.21 \\
(0.56)\end{array}$ & 20 & 0.22 \\
\hline
\end{tabular}

(continued on next page) 
TABLE A9 (continued)

PREDICTIVE REGRESSIONS WITH TIME DUMMIES, CHANGES IN NOMINAL EXCHANGE RATES,

20 COUNTRIES (ARGENTINA, BRAZIL, POLAND, RUSSIA OMITTED), 1994-2008

$-\left(\mathrm{s}_{\mathrm{c}, \mathrm{t}+\mathrm{h}}-\mathrm{s}_{\mathrm{c}, \mathrm{t}}\right)=\sum_{\tau} \alpha_{\mathrm{s}, \tau, \tau+\mathrm{h}} \mathrm{D}_{\tau, \mathrm{t}}+\phi_{\mathrm{s}}^{\mathrm{h}} \mathrm{d}_{\mathrm{c}, \mathrm{t}}+\mathrm{u}_{\mathrm{s}, \mathrm{c}, \mathrm{t}}^{\mathrm{h}} \quad$ (Standard errors in parentheses)

\begin{tabular}{|c|c|c|c|c|c|c|c|c|c|c|c|c|c|c|c|c|c|c|}
\hline \multirow[b]{2}{*}{$\begin{array}{l}\mathrm{h} \\
\text { (1) } \\
\end{array}$} & \multicolumn{14}{|c|}{ Year dummies $\alpha_{s, \tau, \tau+h}(\times 100)$} & \multirow{2}{*}{$\begin{array}{c}\eta^{\mathrm{h}}= \\
\left(1 / \mathrm{N}^{\mathrm{h}}\right) \sum_{\tau} \alpha_{\mathrm{s}, \tau, \tau+\mathrm{h}} \\
(\times 100) \\
(16)\end{array}$} & \multirow{2}{*}{$\begin{array}{l}\text { Slope } \\
\phi_{\mathrm{S}}^{\mathrm{h}} \\
(17)\end{array}$} & \multirow{2}{*}{$\begin{array}{l}\text { No. } \\
\text { of } \\
\text { Obs. } \\
\text { (18) }\end{array}$} & \multirow[b]{2}{*}{$\begin{array}{l}\mathrm{R}^{2} \\
\text { (19) }\end{array}$} \\
\hline & $\begin{array}{c}94,94+\mathrm{h} \\
(2)\end{array}$ & $\begin{array}{c}95,95+h \\
(3)\end{array}$ & $\begin{array}{c}96,96+h \\
(4)\end{array}$ & $\begin{array}{c}97,97+\mathrm{h} \\
(5)\end{array}$ & $\begin{array}{c}98,98+h \\
(6)\end{array}$ & $\begin{array}{c}99,99+h \\
(7) \\
\end{array}$ & $\begin{array}{c}00,00+\mathrm{h} \\
(8)\end{array}$ & $\begin{array}{c}01,01+\mathrm{h} \\
(9)\end{array}$ & $\begin{array}{c}02,02+\mathrm{h} \\
(10)\end{array}$ & $\begin{array}{c}03,03+\mathrm{h} \\
(11) \\
\end{array}$ & $\begin{array}{c}04,04+\mathrm{h} \\
(12)\end{array}$ & $\begin{array}{c}05,05+\mathrm{h} \\
(13)\end{array}$ & $\begin{array}{c}06,06+h \\
(14)\end{array}$ & $\begin{array}{c}07,07+\mathrm{h} \\
(15)\end{array}$ & & & & \\
\hline \multicolumn{19}{|c|}{ B. Without overlapping observations } \\
\hline 1 & $\begin{array}{c}5.55 \\
(4.15)\end{array}$ & $\begin{array}{l}-2.52 \\
(2.52)\end{array}$ & $\begin{array}{l}-4.50 \\
(2.04)\end{array}$ & $\begin{array}{l}-13.17 \\
(3.14)\end{array}$ & $\begin{array}{l}-2.17 \\
(1.43)\end{array}$ & $\begin{array}{l}-3.39 \\
(1.89)\end{array}$ & $\begin{array}{l}-9.28 \\
(1.63)\end{array}$ & $\begin{array}{c}0.22 \\
(1.53)\end{array}$ & $\begin{array}{c}7.69 \\
(2.30)\end{array}$ & $\begin{array}{c}5.00 \\
(1.20)\end{array}$ & $\begin{array}{c}4.81 \\
(1.12)\end{array}$ & $\begin{array}{c}1.71 \\
(1.22)\end{array}$ & $\begin{array}{c}5.47 \\
(1.62)\end{array}$ & $\begin{array}{c}9.42 \\
(2.30)\end{array}$ & $\begin{array}{c}0.35 \\
(0.59)\end{array}$ & $\begin{array}{l}-0.11 \\
(0.07)\end{array}$ & 280 & 0.36 \\
\hline 2 & $\begin{array}{c}2.96 \\
(4.93)\end{array}$ & & $\begin{array}{c}-16.38 \\
(4.11)\end{array}$ & & $\begin{array}{l}-7.09 \\
(2.60)\end{array}$ & & $\begin{array}{l}-8.94 \\
(2.04)\end{array}$ & & $\begin{array}{l}12.00 \\
(3.24)\end{array}$ & & $\begin{array}{c}6.16 \\
(1.57)\end{array}$ & & $\begin{array}{l}14.95 \\
(3.09)\end{array}$ & & $\begin{array}{c}0.52 \\
(1.16)\end{array}$ & $\begin{array}{l}-0.28 \\
(0.15)\end{array}$ & 140 & 0.45 \\
\hline 3 & $\begin{array}{c}0.22 \\
(5.11)\end{array}$ & & & $\begin{array}{l}-14.00 \\
(3.55)\end{array}$ & & & $\begin{array}{l}-2.97 \\
(2.36)\end{array}$ & & & $\begin{array}{l}10.04 \\
(2.29)\end{array}$ & & & & & $\begin{array}{l}-1.68 \\
(1.89)\end{array}$ & $\begin{array}{l}-0.60 \\
(0.15)\end{array}$ & 80 & 0.45 \\
\hline 4 & $\begin{array}{l}-12.17 \\
(5.73)\end{array}$ & & & & $\begin{array}{l}-18.66 \\
(2.97)\end{array}$ & & & & $\begin{array}{l}16.07 \\
(3.37)\end{array}$ & & & & & & $\begin{array}{l}-4.92 \\
(2.46)\end{array}$ & $\begin{array}{l}-0.75 \\
(0.26)\end{array}$ & 60 & 0.58 \\
\hline 5 & $\begin{array}{c}-14.10 \\
(6.05)\end{array}$ & & & & & $\begin{array}{l}2.47 \\
(2.57)\end{array}$ & & & & & & & & & $\begin{array}{l}-5.82 \\
(3.57)\end{array}$ & $\begin{array}{l}-0.66 \\
(0.35)\end{array}$ & 40 & 0.36 \\
\hline 6 & $\begin{array}{r}-17.35 \\
(6.15)\end{array}$ & & & & & & $\begin{array}{c}9.47 \\
(3.68)\end{array}$ & & & & & & & & $\begin{array}{l}-3.94 \\
(3.66)\end{array}$ & $\begin{array}{l}-0.64 \\
(0.32)\end{array}$ & 40 & 0.49 \\
\hline 7 & $\begin{array}{l}-22.54 \\
(6.17)\end{array}$ & & & & & & & $\begin{array}{l}24.84 \\
(6.38)\end{array}$ & & & & & & & $\begin{array}{c}1.15 \\
(3.81)\end{array}$ & $\begin{array}{l}-0.97 \\
(0.38)\end{array}$ & 40 & 0.71 \\
\hline 8 & $\begin{array}{l}-24.96 \\
(6.67)\end{array}$ & & & & & & & & & & & & & & $\begin{array}{l}-24.96 \\
(6.67)\end{array}$ & $\begin{array}{l}-0.55 \\
(0.42)\end{array}$ & 20 & 0.09 \\
\hline 9 & $\begin{array}{r}-14.16 \\
(6.50)\end{array}$ & & & & & & & & & & & & & & $\begin{array}{l}-14.16 \\
(6.50)\end{array}$ & $\begin{array}{l}-0.79 \\
(0.51)\end{array}$ & 20 & 0.14 \\
\hline 10 & $\begin{array}{l}-7.82 \\
(6.74)\end{array}$ & & & & & & & & & & & & & & $\begin{array}{l}-7.82 \\
(6.74)\end{array}$ & $\begin{array}{l}-0.87 \\
(0.57)\end{array}$ & 20 & 0.15 \\
\hline 11 & $\begin{array}{l}-2.24 \\
(6.79)\end{array}$ & & & & & & & & & & & & & & $\begin{array}{l}-2.24 \\
(6.79)\end{array}$ & $\begin{array}{l}-0.91 \\
(0.58)\end{array}$ & 20 & 0.16 \\
\hline 12 & $\begin{array}{l}-0.18 \\
(7.00)\end{array}$ & & & & & & & & & & & & & & $\begin{array}{l}-0.18 \\
(7.00)\end{array}$ & $\begin{array}{l}-0.91 \\
(0.53)\end{array}$ & 20 & 0.15 \\
\hline 13 & $\begin{array}{c}7.67 \\
(6.62)\end{array}$ & & & & & & & & & & & & & & $\begin{array}{c}7.67 \\
(6.62)\end{array}$ & $\begin{array}{l}-1.15 \\
(0.50)\end{array}$ & 20 & 0.23 \\
\hline 14 & $\begin{array}{l}17.81 \\
(7.26)\end{array}$ & & & & & & & & & & & & & & $\begin{array}{l}17.81 \\
(7.26)\end{array}$ & $\begin{array}{l}-1.21 \\
(0.56)\end{array}$ & 20 & 0.22 \\
\hline
\end{tabular}

Note: Standard errors are robust, based on a cluster correction (Kleok, 1981). 
TABLE A10

PREDICTIVE REGRESSIONS WITH TIME DUMMIES, INFLATION DIFFERENTIALS, 20 COUNTRIES,

(ARGENTINA, BRAZIL, POLAND, RUSSIA OMITTED), 1994-2008

$\mathrm{r}_{\mathrm{c}, \mathrm{t}+\mathrm{h}}-\mathrm{r}_{\mathrm{c}, \mathrm{t}}=\sum_{\tau} \alpha_{\mathrm{r}, \tau, \tau+\mathrm{h}} \mathrm{D}_{\tau, \mathrm{t}}+\phi_{\mathrm{r}}^{\mathrm{h}} \mathrm{d}_{\mathrm{c}, \mathrm{t}}+\mathrm{u}_{\mathrm{r}, \mathrm{c}, \mathrm{t}}^{\mathrm{h}}$

(Standard errors in parentheses)

\begin{tabular}{|c|c|c|c|c|c|c|c|c|c|c|c|c|c|c|c|c|c|c|}
\hline \multirow[b]{2}{*}{$\mathrm{h}$} & \multicolumn{14}{|c|}{ Year dummies $\alpha_{\mathrm{r}, \tau, \tau+\mathrm{h}}(\times 100)$} & \multirow{2}{*}{$\begin{array}{c}\eta^{\mathrm{h}}= \\
\left(1 / \mathrm{N}^{\mathrm{h}}\right) \sum_{\tau} \alpha_{\mathrm{r}, \tau, \tau+\mathrm{h}} \\
(\times 100) \\
(16)\end{array}$} & \multirow{2}{*}{$\begin{array}{l}\text { Slope } \\
\phi_{\mathrm{r}}^{\mathrm{h}} \\
(17)\end{array}$} & \multirow{2}{*}{$\begin{array}{c}\text { No. } \\
\text { of } \\
\text { Obs. } \\
\text { (18) }\end{array}$} & \multirow{2}{*}{$\mathrm{R}^{2}$} \\
\hline & $\begin{array}{c}94,94+h \\
(2)\end{array}$ & $\begin{array}{c}95,95+h \\
(3)\end{array}$ & $\begin{array}{c}96,96+h \\
(4)\end{array}$ & $\begin{array}{c}97,97+h \\
(5)\end{array}$ & $\begin{array}{c}98,98+h \\
(6)\end{array}$ & $\begin{array}{c}99,99+\mathrm{h} \\
(7)\end{array}$ & $\begin{array}{c}00,00+\mathrm{h} \\
(8)\end{array}$ & $\begin{array}{c}01,01+\mathrm{h} \\
(9)\end{array}$ & $\begin{array}{c}02,02+\mathrm{h} \\
(10)\end{array}$ & $\begin{array}{c}03,03+\mathrm{h} \\
(11)\end{array}$ & $\begin{array}{c}04,04+h \\
(12)\end{array}$ & $\begin{array}{c}05,05+\mathrm{h} \\
(13)\end{array}$ & $\begin{array}{c}06,06+h \\
(14)\end{array}$ & $\begin{array}{c}07,07+h \\
(15)\end{array}$ & & & & \\
\hline \multicolumn{19}{|c|}{ A. With overlapping observations } \\
\hline 1 & $\begin{array}{c}3.23 \\
(1.88)\end{array}$ & $\begin{array}{c}2.34 \\
(1.83)\end{array}$ & $\begin{array}{c}2.57 \\
(1.50)\end{array}$ & $\begin{array}{l}-2.31 \\
(1.58)\end{array}$ & $\begin{array}{c}7.31 \\
(0.76)\end{array}$ & $\begin{array}{l}-2.64 \\
(0.64)\end{array}$ & $\begin{array}{c}1.60 \\
(1.04)\end{array}$ & $\begin{array}{c}2.94 \\
(1.32)\end{array}$ & $\begin{array}{l}-7.23 \\
(0.92)\end{array}$ & $\begin{array}{l}-5.58 \\
(0.96)\end{array}$ & $\begin{array}{l}-4.89 \\
(1.60)\end{array}$ & $\begin{array}{c}0.28 \\
(0.76)\end{array}$ & $\begin{array}{l}-6.32 \\
(1.13)\end{array}$ & $\begin{array}{c}1.68 \\
(1.65)\end{array}$ & $\begin{array}{l}-0.50 \\
(0.57)\end{array}$ & $\begin{array}{l}-0.15 \\
(0.03)\end{array}$ & 280 & 0.39 \\
\hline 2 & $\begin{array}{c}4.58 \\
(3.42)\end{array}$ & $\begin{array}{c}5.43 \\
(2.28)\end{array}$ & $\begin{array}{c}0.91 \\
(1.98)\end{array}$ & $\begin{array}{c}7.49 \\
(2.02)\end{array}$ & $\begin{array}{c}3.59 \\
(1.18)\end{array}$ & $\begin{array}{l}-0.22 \\
(1.12)\end{array}$ & $\begin{array}{c}5.43 \\
(1.59)\end{array}$ & $\begin{array}{l}-5.17 \\
(1.79)\end{array}$ & $\begin{array}{c}-13.08 \\
(1.31)\end{array}$ & $\begin{array}{r}-10.52 \\
(2.09)\end{array}$ & $\begin{array}{l}-4.72 \\
(1.93)\end{array}$ & $\begin{array}{l}-6.43 \\
(1.26)\end{array}$ & $\begin{array}{l}-4.52 \\
(1.78)\end{array}$ & & $\begin{array}{l}-1.33 \\
(1.09)\end{array}$ & $\begin{array}{l}-0.29 \\
(0.07)\end{array}$ & 260 & 0.39 \\
\hline 3 & $\begin{array}{c}6.27 \\
(4.12)\end{array}$ & $\begin{array}{c}3.52 \\
(2.91)\end{array}$ & $\begin{array}{c}10.78 \\
(2.65)\end{array}$ & $\begin{array}{c}5.83 \\
(2.37)\end{array}$ & $\begin{array}{c}5.46 \\
(1.64)\end{array}$ & $\begin{array}{c}4.50 \\
(1.72)\end{array}$ & $\begin{array}{l}-1.46 \\
(1.64)\end{array}$ & $\begin{array}{l}-11.23 \\
(2.09)\end{array}$ & $\begin{array}{l}-17.98 \\
(2.30)\end{array}$ & $\begin{array}{c}-10.20 \\
(2.22)\end{array}$ & $\begin{array}{l}-11.35 \\
(1.61)\end{array}$ & $\begin{array}{l}-4.85 \\
(2.04)\end{array}$ & & & $\begin{array}{l}-1.73 \\
(1.54)\end{array}$ & $\begin{array}{l}-0.38 \\
(0.09)\end{array}$ & 240 & 0.41 \\
\hline 4 & $\begin{array}{c}3.50 \\
(4.90)\end{array}$ & $\begin{array}{l}13.25 \\
(3.95)\end{array}$ & $\begin{array}{c}9.17 \\
(3.37)\end{array}$ & $\begin{array}{c}8.98 \\
(2.71)\end{array}$ & $\begin{array}{c}9.84 \\
(2.29)\end{array}$ & $\begin{array}{c}-1.85 \\
(1.90)\end{array}$ & $\begin{array}{l}-6.79 \\
(1.92)\end{array}$ & $\begin{array}{l}-16.27 \\
(3.13)\end{array}$ & $\begin{array}{l}-17.62 \\
(2.53)\end{array}$ & $\begin{array}{r}-16.73 \\
(1.88)\end{array}$ & $\begin{array}{c}-9.73 \\
(2.16)\end{array}$ & & & & $\begin{array}{l}-2.20 \\
(1.98)\end{array}$ & $\begin{array}{l}-0.43 \\
(0.13)\end{array}$ & 220 & 0.42 \\
\hline 5 & $\begin{array}{l}12.93 \\
(5.81)\end{array}$ & $\begin{array}{r}11.95 \\
(5.14)\end{array}$ & $\begin{array}{c}12.64 \\
(4.17)\end{array}$ & $\begin{array}{c}14.33 \\
(3.50)\end{array}$ & $\begin{array}{c}3.02 \\
(2.42)\end{array}$ & $\begin{array}{l}-6.89 \\
(2.16)\end{array}$ & $\begin{array}{l}-11.55 \\
(2.75)\end{array}$ & $\begin{array}{c}-16.34 \\
(3.66)\end{array}$ & $\begin{array}{l}-24.30 \\
(2.33)\end{array}$ & $\begin{array}{c}-15.16 \\
(2.40)\end{array}$ & & & & & $\begin{array}{l}-1.94 \\
(2.42)\end{array}$ & $\begin{array}{l}-0.49 \\
(0.18)\end{array}$ & 200 & 0.43 \\
\hline 6 & $\begin{array}{l}11.41 \\
(6.70)\end{array}$ & $\begin{array}{c}15.92 \\
(6.18)\end{array}$ & $\begin{array}{l}18.46 \\
(5.17)\end{array}$ & $\begin{array}{c}8.63 \\
(4.02)\end{array}$ & $\begin{array}{l}-2.65 \\
(2.70)\end{array}$ & $\begin{array}{l}-11.38 \\
(2.88)\end{array}$ & $\begin{array}{c}-11.41 \\
(2.96)\end{array}$ & $\begin{array}{l}-23.62 \\
(3.62)\end{array}$ & $\begin{array}{l}-22.98 \\
(2.79)\end{array}$ & & & & & & $\begin{array}{l}-1.96 \\
(2.87)\end{array}$ & $\begin{array}{l}-0.56 \\
(0.22)\end{array}$ & 180 & 0.39 \\
\hline 7 & $\begin{array}{l}14.83 \\
(7.40)\end{array}$ & $\begin{array}{l}21.93 \\
(7.17)\end{array}$ & $\begin{array}{r}13.04 \\
(5.76)\end{array}$ & $\begin{array}{c}4.19 \\
(4.48)\end{array}$ & $\begin{array}{c}-7.63 \\
(3.90)\end{array}$ & $\begin{array}{c}-10.82 \\
(3.00)\end{array}$ & $\begin{array}{l}-18.21 \\
(2.95)\end{array}$ & $\begin{array}{l}-22.68 \\
(4.21)\end{array}$ & & & & & & & $\begin{array}{l}-0.67 \\
(3.37)\end{array}$ & $\begin{array}{l}-0.63 \\
(0.27)\end{array}$ & 160 & 0.33 \\
\hline 8 & $\begin{array}{l}20.74 \\
(8.24)\end{array}$ & $\begin{array}{l}17.29 \\
(8.02)\end{array}$ & $\begin{array}{c}9.29 \\
(6.42)\end{array}$ & $\begin{array}{c}0.56 \\
(5.00)\end{array}$ & $\begin{array}{l}-7.92 \\
(4.17)\end{array}$ & $\begin{array}{l}-17.34 \\
(2.74)\end{array}$ & $\begin{array}{l}-17.14 \\
(3.11)\end{array}$ & & & & & & & & $\begin{array}{c}0.78 \\
(4.17)\end{array}$ & $\begin{array}{l}-0.73 \\
(0.30)\end{array}$ & 140 & 0.32 \\
\hline 9 & $\begin{array}{l}15.39 \\
(8.90)\end{array}$ & $\begin{array}{r}13.79 \\
(8.86)\end{array}$ & $\begin{array}{c}6.02 \\
(6.87)\end{array}$ & $\begin{array}{c}1.88 \\
(5.30)\end{array}$ & $\begin{array}{c}-15.10 \\
(4.03)\end{array}$ & $\begin{array}{c}-15.73 \\
(2.84)\end{array}$ & & & & & & & & & $\begin{array}{c}1.04 \\
(5.10)\end{array}$ & $\begin{array}{l}-0.81 \\
(0.33)\end{array}$ & 120 & 0.26 \\
\hline 10 & $\begin{array}{l}11.10 \\
(9.36)\end{array}$ & $\begin{array}{r}10.49 \\
(9.03)\end{array}$ & $\begin{array}{c}7.47 \\
(6.99)\end{array}$ & $\begin{array}{c}-3.98 \\
(5.39)\end{array}$ & $\begin{array}{l}-13.90 \\
(4.23)\end{array}$ & & & & & & & & & & $\begin{array}{c}2.24 \\
(5.98)\end{array}$ & $\begin{array}{l}-0.88 \\
(0.33)\end{array}$ & 100 & 0.23 \\
\hline 11 & $\begin{array}{c}8.01 \\
(9.72)\end{array}$ & $\begin{array}{l}13.18 \\
(8.94)\end{array}$ & $\begin{array}{c}2.63 \\
(6.97)\end{array}$ & $\begin{array}{l}-1.31 \\
(5.18)\end{array}$ & & & & & & & & & & & $\begin{array}{c}5.63 \\
(7.42)\end{array}$ & $\begin{array}{l}-1.00 \\
(0.32)\end{array}$ & 80 & 0.26 \\
\hline 12 & $\begin{array}{c}9.08 \\
(9.66)\end{array}$ & $\begin{array}{c}7.46 \\
(8.92)\end{array}$ & $\begin{array}{c}4.87 \\
(6.63)\end{array}$ & & & & & & & & & & & & $\begin{array}{c}7.14 \\
(8.14)\end{array}$ & $\begin{array}{l}-1.03 \\
(0.30)\end{array}$ & 60 & 0.27 \\
\hline 13 & $\begin{array}{c}2.48 \\
(9.28)\end{array}$ & $\begin{array}{c}8.77 \\
(7.88)\end{array}$ & & & & & & & & & & & & & $\begin{array}{c}5.63 \\
(8.36)\end{array}$ & $\begin{array}{l}-1.00 \\
(0.25)\end{array}$ & 40 & 0.25 \\
\hline 14 & $\begin{array}{c}1.60 \\
(8.12)\end{array}$ & & & & & & & & & & & & & & $\begin{array}{c}1.60 \\
(8.12)\end{array}$ & $\begin{array}{l}-0.72 \\
(0.53)\end{array}$ & 20 & 0.08 \\
\hline
\end{tabular}

(continued on next page) 
TABLE A10 (continued)

PREDICTIVE REGRESSIONS WITH TIME DUMMIES, INFLATION DIFFERENTIALS, 20 COUNTRIES,

(ARGENTINA, BRAZIL, POLAND, RUSSIA OMITTED), 1994-2008

$\mathrm{r}_{\mathrm{c}, \mathrm{t}+\mathrm{h}}-\mathrm{r}_{\mathrm{c}, \mathrm{t}}=\sum_{\tau} \alpha_{\mathrm{r}, \tau, \tau+\mathrm{h}} \mathrm{D}_{\tau, \mathrm{t}}+\phi_{\mathrm{r}}^{\mathrm{h}} \mathrm{d}_{\mathrm{c}, \mathrm{t}}+\mathrm{u}_{\mathrm{r}, \mathrm{c}, \mathrm{t}}^{\mathrm{h}} \quad$ (Standard errors in parentheses)

\begin{tabular}{|c|c|c|c|c|c|c|c|c|c|c|c|c|c|c|c|c|c|c|}
\hline \multirow[b]{2}{*}{$\begin{array}{l}\mathrm{h} \\
\text { (1) }\end{array}$} & \multirow[b]{2}{*}{$\begin{array}{l}94,94+h \\
(2) \\
\end{array}$} & \multirow[b]{2}{*}{$\begin{array}{l}95,95+\mathrm{h} \\
(3)\end{array}$} & \multirow[b]{2}{*}{$\begin{array}{c}96,96+h \\
(4) \\
\end{array}$} & \multirow[b]{2}{*}{$\begin{array}{c}97,97+\mathrm{h} \\
(5)\end{array}$} & \multirow[b]{2}{*}{$\begin{array}{c}98,98+h \\
(6)\end{array}$} & \multicolumn{9}{|c|}{ Year dummies $\alpha_{\mathrm{r}, \tau, \tau+\mathrm{h}} \quad(\times 100)$} & \multirow{2}{*}{$\begin{array}{c}\eta^{\mathrm{h}}= \\
\left(1 / \mathrm{N}^{\mathrm{h}}\right) \sum_{\tau} \alpha_{\mathrm{r}, \tau, \tau+\mathrm{h}} \\
(\times 100) \\
(16)\end{array}$} & \multirow{2}{*}{$\begin{array}{l}\text { Slope } \\
\phi_{\mathrm{r}}^{\mathrm{h}} \\
(17)\end{array}$} & \multirow{2}{*}{$\begin{array}{l}\text { No. } \\
\text { of } \\
\text { Obs. } \\
(18)\end{array}$} & \multirow[b]{2}{*}{$\begin{array}{l}\mathrm{R}^{2} \\
(19)\end{array}$} \\
\hline & & & & & & $\begin{array}{c}99,99+\mathrm{h} \\
(7) \\
\end{array}$ & $\begin{array}{c}00,00+\mathrm{h} \\
(8) \\
\end{array}$ & $\begin{array}{c}01,01+\mathrm{h} \\
(9) \\
\end{array}$ & $\begin{array}{c}02,02+\mathrm{h} \\
(10)\end{array}$ & $\begin{array}{c}03,03+\mathrm{h} \\
(11)\end{array}$ & $\begin{array}{c}04,04+\mathrm{h} \\
(12)\end{array}$ & $\begin{array}{c}05,05+h \\
(13)\end{array}$ & $\begin{array}{c}06,06+h \\
(14)\end{array}$ & $\begin{array}{c}07,07+h \\
(15)\end{array}$ & & & & \\
\hline \multicolumn{19}{|c|}{ B. Without overlapping observations } \\
\hline 1 & $\begin{array}{c}3.23 \\
(1.89)\end{array}$ & $\begin{array}{c}2.34 \\
(1.83)\end{array}$ & $\begin{array}{c}2.57 \\
(1.50)\end{array}$ & $\begin{array}{l}-2.31 \\
(1.58)\end{array}$ & $\begin{array}{c}7.31 \\
(0.77)\end{array}$ & $\begin{array}{l}-2.64 \\
(0.64)\end{array}$ & $\begin{array}{c}1.60 \\
(1.04)\end{array}$ & $\begin{array}{c}2.94 \\
(1.32)\end{array}$ & $\begin{array}{l}-7.23 \\
(0.92)\end{array}$ & $\begin{array}{l}-5.58 \\
(0.96)\end{array}$ & $\begin{array}{l}-4.89 \\
(1.60)\end{array}$ & $\begin{array}{c}0.28 \\
(0.76)\end{array}$ & $\begin{array}{l}-6.32 \\
(1.13)\end{array}$ & $\begin{array}{c}1.68 \\
(1.65)\end{array}$ & $\begin{array}{l}-0.50 \\
(0.57)\end{array}$ & $\begin{array}{l}-0.15 \\
(0.03)\end{array}$ & 280 & 0.39 \\
\hline 2 & $\begin{array}{c}4.04 \\
(3.14)\end{array}$ & & $\begin{array}{c}0.26 \\
(2.05)\end{array}$ & & $\begin{array}{c}4.17 \\
(1.42)\end{array}$ & & $\begin{array}{c}5.87 \\
(1.62)\end{array}$ & & $\begin{array}{l}-12.70 \\
(1.37)\end{array}$ & & $\begin{array}{l}-4.50 \\
(1.96)\end{array}$ & & $\begin{array}{l}-4.50 \\
(1.71)\end{array}$ & & $\begin{array}{l}-1.05 \\
(1.19)\end{array}$ & $\begin{array}{l}-0.23 \\
(0.08)\end{array}$ & 140 & 0.37 \\
\hline 3 & $\begin{array}{c}5.68 \\
(3.95)\end{array}$ & & & $\begin{array}{c}5.43 \\
(2.40)\end{array}$ & & & $\begin{array}{l}-0.99 \\
(1.88)\end{array}$ & & & $\begin{array}{l}-9.92 \\
(2.39)\end{array}$ & & & & & $\begin{array}{c}0.05 \\
(1.92)\end{array}$ & $\begin{array}{l}-0.32 \\
(0.13)\end{array}$ & 80 & 0.21 \\
\hline 4 & $\begin{array}{c}2.36 \\
(4.18)\end{array}$ & & & & $\begin{array}{l}11.05 \\
(3.31)\end{array}$ & & & & $\begin{array}{l}-16.82 \\
(3.29)\end{array}$ & & & & & & $\begin{array}{l}-1.14 \\
(2.99)\end{array}$ & $\begin{array}{l}-0.31 \\
(0.24)\end{array}$ & 60 & 0.41 \\
\hline 5 & $\begin{array}{l}12.22 \\
(5.52)\end{array}$ & & & & & $\begin{array}{l}-6.70 \\
(2.42)\end{array}$ & & & & & & & & & $\begin{array}{c}2.76 \\
(3.50)\end{array}$ & $\begin{array}{l}-0.42 \\
(0.33)\end{array}$ & 40 & 0.18 \\
\hline 6 & $\begin{array}{c}9.78 \\
(5.73)\end{array}$ & & & & & & $\begin{array}{l}-10.09 \\
(4.10)\end{array}$ & & & & & & & & $\begin{array}{c}-0.15 \\
(3.80)\end{array}$ & $\begin{array}{l}-0.40 \\
(0.29)\end{array}$ & 40 & 0.15 \\
\hline 7 & $\begin{array}{l}11.91 \\
(5.70)\end{array}$ & & & & & & & $\begin{array}{r}-18.63 \\
(5.88)\end{array}$ & & & & & & & $\begin{array}{l}-3.36 \\
(4.35)\end{array}$ & $\begin{array}{l}-0.33 \\
(0.33)\end{array}$ & 40 & 0.25 \\
\hline 8 & $\begin{array}{l}18.64 \\
(6.70)\end{array}$ & & & & & & & & & & & & & & $\begin{array}{l}18.64 \\
(6.70)\end{array}$ & $\begin{array}{l}-0.51 \\
(0.48)\end{array}$ & 20 & 0.06 \\
\hline 9 & $\begin{array}{c}11.82 \\
(7.09)\end{array}$ & & & & & & & & & & & & & & $\begin{array}{l}11.82 \\
(7.09)\end{array}$ & $\begin{array}{l}-0.45 \\
(0.53)\end{array}$ & 20 & 0.05 \\
\hline 10 & $\begin{array}{c}7.67 \\
(7.60)\end{array}$ & & & & & & & & & & & & & & $\begin{array}{c}7.67 \\
(7.60)\end{array}$ & $\begin{array}{l}-0.53 \\
(0.53)\end{array}$ & 20 & 0.06 \\
\hline 11 & $\begin{array}{c}4.30 \\
(7.72)\end{array}$ & & & & & & & & & & & & & & $\begin{array}{c}4.30 \\
(7.72)\end{array}$ & $\begin{array}{l}-0.62 \\
(0.56)\end{array}$ & 20 & 0.07 \\
\hline 12 & $\begin{array}{c}5.40 \\
(7.92)\end{array}$ & & & & & & & & & & & & & & $\begin{array}{c}5.40 \\
(7.92)\end{array}$ & $\begin{array}{l}-0.66 \\
(0.57)\end{array}$ & 20 & 0.07 \\
\hline 13 & $\begin{array}{l}-1.98 \\
(8.21)\end{array}$ & & & & & & & & & & & & & & $\begin{array}{l}-1.98 \\
(8.21)\end{array}$ & $\begin{array}{l}-0.54 \\
(0.54)\end{array}$ & 20 & 0.05 \\
\hline 14 & $\begin{array}{c}1.60 \\
(8.12)\end{array}$ & & & & & & & & & & & & & & $\begin{array}{c}1.60 \\
(8.12)\end{array}$ & $\begin{array}{l}-0.72 \\
(0.53)\end{array}$ & 20 & 0.08 \\
\hline
\end{tabular}


TABLE A11

SEEMINGLY UNRELATED REGRESSIONS UNDER FULL ADJUSTMENT WITH TIME DUMMIES,

20 COUNTRIES, (ARGENTINA, BRAZIL, POLAND, RUSSIA OMITTED), 1994-2008

$-\left(\mathrm{s}_{\mathrm{c}, \mathrm{t}+\mathrm{H}}{ }^{-\mathrm{s}_{\mathrm{c}, \mathrm{t}}}\right)=\sum_{\tau} \alpha_{\mathrm{s}, \tau, \tau+\mathrm{H}} \mathrm{D}_{\tau, \mathrm{t}}+\phi_{\mathrm{s}}^{\mathrm{H}} \mathrm{d}_{\mathrm{c}, \mathrm{t}}+\mathrm{u}_{\mathrm{s}, \mathrm{c}, \mathrm{t}}^{\mathrm{H}}$ and $\mathrm{r}_{\mathrm{c}, \mathrm{t}+\mathrm{H}} \mathrm{r}_{\mathrm{c}, \mathrm{t}}=\sum_{\tau} \alpha_{\mathrm{r}, \tau, \tau+\mathrm{H}} \mathrm{D}_{\tau, \mathrm{t}}+\phi_{\mathrm{r}}^{\mathrm{H}} \mathrm{d}_{\mathrm{c}, \mathrm{t}}+\mathrm{u}_{\mathrm{r}, \mathrm{c}, \mathrm{t}}^{\mathrm{H}} \quad$ with $\eta_{\mathrm{s}}^{\mathrm{H}}+\eta_{\mathrm{r}}^{\mathrm{H}}=0, \phi_{\mathrm{s}}^{\mathrm{H}}+\phi_{\mathrm{r}}^{\mathrm{H}}=-1$

(Standard errors in parentheses)

\begin{tabular}{|c|c|c|c|c|c|c|c|c|c|c|c|c|c|c|c|c|c|}
\hline \multirow[b]{2}{*}{$\begin{array}{l}\mathrm{H} \\
\text { (1) } \\
\end{array}$} & \multicolumn{14}{|c|}{ Year dummies $\alpha_{\mathrm{s}, \tau, \tau+\mathrm{H}}(\times 100)$} & \multirow{2}{*}{$\begin{array}{c}\eta^{\mathrm{H}}= \\
\left(1 / \mathrm{N}^{\mathrm{H}}\right) \sum_{\tau} \alpha_{\mathrm{s}, \tau, \tau+\mathrm{H}} \\
(\times 100) \\
(16)\end{array}$} & \multirow{2}{*}{$\begin{array}{l}\text { Slope } \\
\phi_{\mathrm{S}}^{\mathrm{H}} \\
(17)\end{array}$} & \multirow{2}{*}{$\begin{array}{c}\text { No. } \\
\text { of } \\
\text { Obs } \\
(18)\end{array}$} \\
\hline & $\begin{array}{c}94,94+\mathrm{H} \\
(2)\end{array}$ & $\begin{array}{c}95,95+\mathrm{H} \\
\text { (3) }\end{array}$ & $\begin{array}{c}96,96+\mathrm{H} \\
\text { (4) }\end{array}$ & $\begin{array}{c}97,97+\mathrm{H} \\
(5)\end{array}$ & $\begin{array}{c}98,98+\mathrm{H} \\
(6)\end{array}$ & $\begin{array}{c}99,99+\mathrm{H} \\
(7)\end{array}$ & $\begin{array}{c}00,00+\mathrm{H} \\
(8)\end{array}$ & $\begin{array}{c}01,01+\mathrm{H} \\
(9)\end{array}$ & $\begin{array}{c}02,02+\mathrm{H} \\
(10)\end{array}$ & $\begin{array}{c}03,03+\mathrm{H} \\
(11)\end{array}$ & $\begin{array}{c}04,04+\mathrm{H} \\
(12)\end{array}$ & $\begin{array}{c}05,05+\mathrm{H} \\
(13)\end{array}$ & $\begin{array}{c}06,06+\mathrm{H} \\
(14)\end{array}$ & $\begin{array}{c}07,07+\mathrm{H} \\
(15)\end{array}$ & & & \\
\hline \multicolumn{18}{|c|}{ A. With overlapping observations } \\
\hline 1 & $\begin{array}{l}10.63 \\
(2.23)\end{array}$ & $\begin{array}{c}5.52 \\
(2.25)\end{array}$ & $\begin{array}{c}1.49 \\
(2.23)\end{array}$ & $\begin{array}{l}-9.52 \\
(2.22)\end{array}$ & $\begin{array}{l}-6.66 \\
(2.23)\end{array}$ & $\begin{array}{l}-4.18 \\
(2.21)\end{array}$ & $\begin{array}{l}-12.60 \\
(2.22)\end{array}$ & $\begin{array}{l}-5.75 \\
(2.24)\end{array}$ & $\begin{array}{c}4.87 \\
(2.22)\end{array}$ & $\begin{array}{c}3.24 \\
(2.21)\end{array}$ & $\begin{array}{c}3.34 \\
(2.21)\end{array}$ & $\begin{array}{c}0.70 \\
(2.21)\end{array}$ & $\begin{array}{c}5.77 \\
(2.21)\end{array}$ & $\begin{array}{c}9.36 \\
(2.21)\end{array}$ & $\begin{array}{c}0.44 \\
(0.59)\end{array}$ & $\begin{array}{l}-0.58 \\
(0.03)\end{array}$ & 280 \\
\hline 3 & $\begin{array}{c}2.44 \\
(3.08)\end{array}$ & $\begin{array}{c}-12.30 \\
(3.15)\end{array}$ & $\begin{array}{l}-11.54 \\
(3.10)\end{array}$ & $\begin{array}{c}-11.74 \\
(3.06)\end{array}$ & $\begin{array}{c}-16.25 \\
(3.09)\end{array}$ & $\begin{array}{l}-8.95 \\
(3.05)\end{array}$ & $\begin{array}{l}-0.51 \\
(3.07)\end{array}$ & $\begin{array}{l}10.13 \\
(3.12)\end{array}$ & $\begin{array}{l}17.55 \\
(3.06)\end{array}$ & $\begin{array}{l}12.45 \\
(3.05)\end{array}$ & $\begin{array}{l}12.81 \\
(3.05)\end{array}$ & $\begin{array}{l}17.64 \\
(3.05)\end{array}$ & & & $\begin{array}{c}0.98 \\
(0.89)\end{array}$ & $\begin{array}{l}-0.58 \\
(0.05)\end{array}$ & 240 \\
\hline 4 & $\begin{array}{l}-11.11 \\
(3.40)\end{array}$ & $\begin{array}{l}-13.04 \\
(3.49)\end{array}$ & $\begin{array}{c}-14.30 \\
(3.42)\end{array}$ & $\begin{array}{l}-19.72 \\
(3.37)\end{array}$ & $\begin{array}{l}-13.84 \\
(3.40)\end{array}$ & $\begin{array}{c}0.07 \\
(3.34)\end{array}$ & $\begin{array}{c}5.66 \\
(3.38)\end{array}$ & $\begin{array}{l}16.12 \\
(3.45)\end{array}$ & $\begin{array}{l}20.23 \\
(3.37)\end{array}$ & $\begin{array}{l}18.55 \\
(3.35)\end{array}$ & $\begin{array}{l}22.93 \\
(3.35)\end{array}$ & & & & $\begin{array}{c}1.05 \\
(1.02)\end{array}$ & $\begin{array}{l}-0.57 \\
(0.06)\end{array}$ & 220 \\
\hline 5 & $\begin{array}{l}-12.85 \\
(3.71)\end{array}$ & $\begin{array}{l}-17.02 \\
(3.83)\end{array}$ & $\begin{array}{l}-23.48 \\
(3.74)\end{array}$ & $\begin{array}{l}-18.66 \\
(3.67)\end{array}$ & $\begin{array}{l}-5.66 \\
(3.72)\end{array}$ & $\begin{array}{c}5.13 \\
(3.64)\end{array}$ & $\begin{array}{l}10.58 \\
(3.68)\end{array}$ & $\begin{array}{l}17.97 \\
(3.78)\end{array}$ & $\begin{array}{l}25.38 \\
(3.67)\end{array}$ & $\begin{array}{l}27.68 \\
(3.65)\end{array}$ & & & & & $\begin{array}{c}0.91 \\
(1.17)\end{array}$ & $\begin{array}{l}-0.54 \\
(0.08)\end{array}$ & 200 \\
\hline 6 & $\begin{array}{l}-16.12 \\
(4.01)\end{array}$ & $\begin{array}{l}-25.63 \\
(4.16)\end{array}$ & $\begin{array}{l}-21.93 \\
(4.05)\end{array}$ & $\begin{array}{l}-10.34 \\
(3.96)\end{array}$ & $\begin{array}{c}-0.16 \\
(4.03)\end{array}$ & $\begin{array}{l}10.32 \\
(3.93)\end{array}$ & $\begin{array}{l}12.60 \\
(3.98)\end{array}$ & $\begin{array}{l}23.48 \\
(4.10)\end{array}$ & $\begin{array}{l}34.87 \\
(3.97)\end{array}$ & & & & & & $\begin{array}{c}0.79 \\
(1.34)\end{array}$ & $\begin{array}{l}-0.54 \\
(0.09)\end{array}$ & 180 \\
\hline 7 & $\begin{array}{l}-25.03 \\
(4.17)\end{array}$ & $\begin{array}{l}-24.28 \\
(4.36)\end{array}$ & $\begin{array}{l}-13.95 \\
(4.22)\end{array}$ & $\begin{array}{l}-5.41 \\
(4.11)\end{array}$ & $\begin{array}{c}4.14 \\
(4.19)\end{array}$ & $\begin{array}{l}11.58 \\
(4.06)\end{array}$ & $\begin{array}{l}17.19 \\
(4.13)\end{array}$ & $\begin{array}{l}31.99 \\
(4.28)\end{array}$ & & & & & & & $\begin{array}{c}-0.47 \\
(1.48)\end{array}$ & $\begin{array}{l}-0.56 \\
(0.10)\end{array}$ & 160 \\
\hline 8 & $\begin{array}{l}-24.50 \\
(4.36)\end{array}$ & $\begin{array}{r}-17.17 \\
(4.59)\end{array}$ & $\begin{array}{l}-9.67 \\
(4.42)\end{array}$ & $\begin{array}{l}-1.27 \\
(4.28)\end{array}$ & $\begin{array}{c}5.49 \\
(4.38)\end{array}$ & $\begin{array}{l}16.19 \\
(4.22)\end{array}$ & $\begin{array}{l}25.97 \\
(4.31)\end{array}$ & & & & & & & & $\begin{array}{c}-0.71 \\
(1.65)\end{array}$ & $\begin{array}{l}-0.53 \\
(0.12)\end{array}$ & 140 \\
\hline 9 & $\begin{array}{l}-17.38 \\
(4.78)\end{array}$ & $\begin{array}{l}-13.60 \\
(5.09)\end{array}$ & $\begin{array}{c}-5.95 \\
(4.86)\end{array}$ & $\begin{array}{c}-0.27 \\
(4.68)\end{array}$ & $\begin{array}{l}11.62 \\
(4.81)\end{array}$ & $\begin{array}{l}25.59 \\
(4.60)\end{array}$ & & & & & & & & & $\begin{array}{c}0.00 \\
(1.96)\end{array}$ & $\begin{array}{l}-0.44 \\
(0.14)\end{array}$ & 120 \\
\hline 10 & $\begin{array}{l}-12.84 \\
(5.25)\end{array}$ & $\begin{array}{l}-9.70 \\
(5.62)\end{array}$ & $\begin{array}{l}-4.99 \\
(5.35)\end{array}$ & $\begin{array}{c}4.45 \\
(5.13)\end{array}$ & $\begin{array}{l}21.42 \\
(5.28)\end{array}$ & & & & & & & & & & $\begin{array}{l}-0.33 \\
(2.38)\end{array}$ & $\begin{array}{c}-0.38 \\
(0.156)\end{array}$ & 100 \\
\hline 11 & $\begin{array}{l}-8.86 \\
(5.77)\end{array}$ & $\begin{array}{l}-9.40 \\
(6.23)\end{array}$ & $\begin{array}{c}-0.91 \\
(5.89)\end{array}$ & $\begin{array}{l}12.93 \\
(5.62)\end{array}$ & & & & & & & & & & & $\begin{array}{l}-1.56 \\
(2.94)\end{array}$ & $\begin{array}{l}-0.30 \\
(0.19)\end{array}$ & 80 \\
\hline 12 & $\begin{array}{l}-7.72 \\
(6.29)\end{array}$ & $\begin{array}{l}-4.91 \\
(6.85)\end{array}$ & $\begin{array}{c}7.69 \\
(6.44)\end{array}$ & & & & & & & & & & & & $\begin{array}{l}-1.65 \\
(3.77)\end{array}$ & $\begin{array}{l}-0.28 \\
(0.21)\end{array}$ & 60 \\
\hline 13 & $\begin{array}{l}-2.51 \\
(6.98)\end{array}$ & $\begin{array}{c}4.64 \\
(7.72)\end{array}$ & & & & & & & & & & & & & $\begin{array}{c}1.06 \\
(5.20)\end{array}$ & $\begin{array}{l}-0.33 \\
(0.26)\end{array}$ & 40 \\
\hline 14 & $\begin{array}{l}10.47 \\
(8.94)\end{array}$ & & & & & & & & & & & & & & $\begin{array}{l}10.47 \\
(8.94)\end{array}$ & $\begin{array}{l}-0.86 \\
(0.50)\end{array}$ & 20 \\
\hline
\end{tabular}


TABLE A11 (continued)

SEEMINGLY UNRELATED REGRESSIONS UNDER FULL ADJUSTMENT WITH TIME DUMMIES,

20 COUNTRIES (ARGENTINA, BRAZIL, POLAND, RUSSIA OMITTED), 1994-2008

$$
-\left(\mathrm{s}_{\mathrm{c}, \mathrm{t}+\mathrm{H}}-\mathrm{s}_{\mathrm{c}, \mathrm{t}}\right)=\sum_{\tau} \alpha_{\mathrm{s}, \tau, \tau+\mathrm{H}} \mathrm{D}_{\tau, \mathrm{t}}+\phi_{\mathrm{s}}^{\mathrm{H}} \mathrm{d}_{\mathrm{c}, \mathrm{t}}+\mathrm{u}_{\mathrm{s}, \mathrm{c}, \mathrm{t}}^{\mathrm{H}} \text { and } \mathrm{r}_{\mathrm{c}, \mathrm{t}+\mathrm{H}} \mathrm{r}_{\mathrm{c}, \mathrm{t}}=\sum_{\tau} \alpha_{\mathrm{r}, \tau, \tau+\mathrm{H}} \mathrm{D}_{\tau, \mathrm{t}}+\phi_{\mathrm{r}}^{\mathrm{H}} \mathrm{d}_{\mathrm{c}, \mathrm{t}}+\mathrm{u}_{\mathrm{r}, \mathrm{c}, \mathrm{t}}^{\mathrm{H}} \quad \text { with } \eta_{\mathrm{s}}^{\mathrm{H}}+\eta_{\mathrm{r}}^{\mathrm{H}}=0, \phi_{\mathrm{s}}^{\mathrm{H}}+\phi_{\mathrm{r}}^{\mathrm{H}}=-1
$$

(Standard errors in parentheses)

\begin{tabular}{|c|c|c|c|c|c|c|c|c|c|c|c|c|c|c|c|c|c|}
\hline \multirow[b]{2}{*}{$\begin{array}{l}\mathrm{H} \\
\text { (1) }\end{array}$} & \multicolumn{14}{|c|}{ Year dummies $\alpha_{\mathrm{s}, \tau, \tau+\mathrm{H}}(\times 100)$} & \multirow{2}{*}{$\begin{array}{c}\eta^{\mathrm{H}}= \\
\left(1 / \mathrm{N}^{\mathrm{H}}\right) \sum_{\tau} \alpha_{\mathrm{s}, \tau, \tau+\mathrm{H}} \\
(\times 100) \\
(16)\end{array}$} & \multirow{2}{*}{$\begin{array}{l}\text { Slope } \\
\phi_{\mathrm{S}}^{\mathrm{h}} \\
(17)\end{array}$} & \multirow{2}{*}{$\begin{array}{c}\text { No. } \\
\text { of } \\
\text { Obs } \\
(18)\end{array}$} \\
\hline & $\begin{array}{c}94,94+\mathrm{H} \\
(2)\end{array}$ & $\begin{array}{c}95,95+\mathrm{H} \\
(3)\end{array}$ & $\begin{array}{c}96,96+\mathrm{H} \\
(4)\end{array}$ & $\begin{array}{c}97,97+\mathrm{H} \\
(5)\end{array}$ & $\begin{array}{c}98,98+\mathrm{H} \\
(6)\end{array}$ & $\begin{array}{c}99,99+\mathrm{H} \\
(7)\end{array}$ & $\begin{array}{c}00,00+\mathrm{H} \\
(8)\end{array}$ & $\begin{array}{c}01,01+\mathrm{H} \\
(9)\end{array}$ & $\begin{array}{c}02,02+\mathrm{H} \\
(10)\end{array}$ & $\begin{array}{c}03,03+\mathrm{H} \\
(11)\end{array}$ & $\begin{array}{c}04,04+\mathrm{H} \\
(12)\end{array}$ & $\begin{array}{c}05,05+\mathrm{H} \\
(13)\end{array}$ & $\begin{array}{c}06,06+\mathrm{H} \\
(14)\end{array}$ & $\begin{array}{c}07,07+\mathrm{H} \\
(15)\end{array}$ & & & \\
\hline \multicolumn{18}{|c|}{ B. Without overlapping observations } \\
\hline 1 & $\begin{array}{l}10.63 \\
(2.23)\end{array}$ & $\begin{array}{c}5.52 \\
(2.25)\end{array}$ & $\begin{array}{c}1.49 \\
(2.23)\end{array}$ & $\begin{array}{l}-9.52 \\
(2.22)\end{array}$ & $\begin{array}{l}-6.66 \\
(2.23)\end{array}$ & $\begin{array}{l}-4.18 \\
(2.21)\end{array}$ & $\begin{array}{l}-12.60 \\
(2.22)\end{array}$ & $\begin{array}{l}-5.76 \\
(2.24)\end{array}$ & $\begin{array}{c}4.87 \\
(2.22)\end{array}$ & $\begin{array}{c}3.24 \\
(2.21)\end{array}$ & $\begin{array}{c}3.34 \\
(2.21)\end{array}$ & $\begin{array}{c}0.70 \\
(2.21)\end{array}$ & $\begin{array}{c}5.77 \\
(2.21)\end{array}$ & $\begin{array}{c}9.36 \\
(2.21)\end{array}$ & $\begin{array}{c}0.44 \\
(0.59)\end{array}$ & $\begin{array}{l}-0.58 \\
(0.03)\end{array}$ & 280 \\
\hline 2 & $\begin{array}{c}7.45 \\
(2.98)\end{array}$ & & $\begin{array}{l}-11.17 \\
(3.01)\end{array}$ & & $\begin{array}{c}-10.14 \\
(2.99)\end{array}$ & & $\begin{array}{l}-11.07 \\
(2.96)\end{array}$ & & $\begin{array}{l}10.27 \\
(2.95)\end{array}$ & & $\begin{array}{c}5.49 \\
(2.93)\end{array}$ & & $\begin{array}{l}15.68 \\
(2.92)\end{array}$ & & $\begin{array}{l}0.931 \\
(1.12)\end{array}$ & $\begin{array}{l}-0.66 \\
(0.06)\end{array}$ & 140 \\
\hline 3 & $\begin{array}{l}2.18 \\
(3.31)\end{array}$ & & & $\begin{array}{l}-12.26 \\
(3.22)\end{array}$ & & & $\begin{array}{l}-2.30 \\
(3.25)\end{array}$ & & & $\begin{array}{l}10.95 \\
(3.18)\end{array}$ & & & & & $\begin{array}{l}-0.36 \\
(1.62)\end{array}$ & $\begin{array}{l}-0.67 \\
(0.11)\end{array}$ & 80 \\
\hline 4 & $\begin{array}{l}-8.50 \\
(3.96)\end{array}$ & & & & $\begin{array}{r}-14.05 \\
(4.00)\end{array}$ & & & & $\begin{array}{l}20.51 \\
(3.82)\end{array}$ & & & & & & $\begin{array}{l}-0.68 \\
(2.27)\end{array}$ & $\begin{array}{l}-0.71 \\
(0.15)\end{array}$ & 60 \\
\hline 5 & $\begin{array}{l}-12.13 \\
(4.85)\end{array}$ & & & & & $\begin{array}{c}5.15 \\
(4.33)\end{array}$ & & & & & & & & & $\begin{array}{l}-3.49 \\
(2.16)\end{array}$ & $\begin{array}{l}-0.60 \\
(0.23)\end{array}$ & 40 \\
\hline 6 & $\begin{array}{l}-14.82 \\
(5.17)\end{array}$ & & & & & & $\begin{array}{l}12.49 \\
(5.02)\end{array}$ & & & & & & & & $\begin{array}{l}-1.17 \\
(3.60)\end{array}$ & $\begin{array}{l}-0.62 \\
(0.22)\end{array}$ & 40 \\
\hline 7 & $\begin{array}{l}-23.44 \\
(5.50)\end{array}$ & & & & & & & $\begin{array}{l}28.77 \\
(5.91)\end{array}$ & & & & & & & $\begin{array}{c}2.66 \\
(4.03)\end{array}$ & $\begin{array}{l}-0.76 \\
(0.23)\end{array}$ & 40 \\
\hline 8 & $\begin{array}{l}-25.60 \\
(7.03)\end{array}$ & & & & & & & & & & & & & & $\begin{array}{l}-25.60 \\
(7.03)\end{array}$ & $\begin{array}{l}-0.55 \\
(0.39)\end{array}$ & 20 \\
\hline 9 & $\begin{array}{l}-14.30 \\
(7.79)\end{array}$ & & & & & & & & & & & & & & $\begin{array}{l}-14.30 \\
(7.79)\end{array}$ & $\begin{array}{l}-0.80 \\
(0.44)\end{array}$ & 20 \\
\hline 10 & $\begin{array}{l}-7.77 \\
(8.43)\end{array}$ & & & & & & & & & & & & & & $\begin{array}{l}-7.77 \\
(8.43)\end{array}$ & $\begin{array}{l}-0.74 \\
(0.47)\end{array}$ & 20 \\
\hline 11 & $\begin{array}{l}-1.79 \\
(8.45)\end{array}$ & & & & & & & & & & & & & & $\begin{array}{l}-1.79 \\
(8.45)\end{array}$ & $\begin{array}{l}-1.02 \\
(0.47)\end{array}$ & 20 \\
\hline 12 & $\begin{array}{c}0.96 \\
(8.71)\end{array}$ & & & & & & & & & & & & & & $\begin{array}{c}0.96 \\
(8.71)\end{array}$ & $\begin{array}{l}-1.03 \\
(0.49)\end{array}$ & 20 \\
\hline 13 & $\begin{array}{c}7.91 \\
(8.45)\end{array}$ & & & & & & & & & & & & & & $\begin{array}{c}7.91 \\
(8.45)\end{array}$ & $\begin{array}{l}-1.17 \\
(0.47)\end{array}$ & 20 \\
\hline 14 & $\begin{array}{l}10.47 \\
(8.94)\end{array}$ & & & & & & & & & & & & & & $\begin{array}{l}10.47 \\
(8.94)\end{array}$ & $\begin{array}{l}-0.86 \\
(0.50)\end{array}$ & 20 \\
\hline
\end{tabular}




\section{TABLE A12 \\ SUMMARY OF PRESENTATION OF RESULTS, HIGH-INFLATION COUNTRIES INCLUDED AND EXCLUDED}

(Number of table containing relevant results)

\begin{tabular}{|c|c|c|}
\hline \multirow{2}{*}{$\begin{array}{l}\text { Impact of currency } \\
\text { mispricing on future } \\
\text { values of } \\
\text { (1) }\end{array}$} & \multicolumn{2}{|c|}{ High-inflation countries } \\
\hline & $\begin{array}{c}\text { Included } \\
\text { (2) }\end{array}$ & $\begin{array}{l}\text { Excluded } \\
\text { (3) }\end{array}$ \\
\hline $\begin{array}{l}\text { 1. Nominal exchange rate, } \\
\text { with time effects } \\
\text { - Excluded } \\
\text { - Included }\end{array}$ & $\begin{array}{l}6.1 \\
\text { A4 }\end{array}$ & $\begin{array}{l}\text { A7 } \\
\text { A9 }\end{array}$ \\
\hline $\begin{array}{l}\text { 2. Prices, with time effects } \\
\text { - Excluded } \\
\text { - Included }\end{array}$ & $\begin{array}{l}6.1 \\
\text { A5 } \\
\end{array}$ & $\begin{array}{c}\text { A7 } \\
\text { A10 }\end{array}$ \\
\hline $\begin{array}{l}\text { 3. Nominal rate and prices } \\
\text { jointly under full } \\
\text { adjustment, with time } \\
\text { effects } \\
\text { - Excluded } \\
\text { - Included }\end{array}$ & $\begin{array}{l}6.2 \\
\text { A6 }\end{array}$ & $\begin{array}{c}\text { A8 } \\
\text { A11 }\end{array}$ \\
\hline
\end{tabular}




\begin{tabular}{|c|c|c|}
\hline \multicolumn{3}{|c|}{$\begin{array}{c}\text { ECONOMICS DISCUSSION PAPERS } \\
2009\end{array}$} \\
\hline $\begin{array}{l}\text { DP } \\
\text { NUMBER }\end{array}$ & AUTHORS & TITLE \\
\hline 09.01 & Le, A.T. & $\begin{array}{l}\text { ENTRY INTO UNIVERSITY: ARE THE CHILDREN OF } \\
\text { IMMIGRANTS DISADVANTAGED? }\end{array}$ \\
\hline 09.02 & $\mathrm{Wu}, \mathrm{Y}$. & CHINA'S CAPITAL STOCK SERIES BY REGION AND SECTOR \\
\hline 09.03 & Chen, M.H. & $\begin{array}{l}\text { UNDERSTANDING WORLD COMMODITY PRICES RETURNS, } \\
\text { VOLATILITY AND DIVERSIFACATION }\end{array}$ \\
\hline 09.04 & Velagic, R. & UWA DISCUSSION PAPERS IN ECONOMICS: THE FIRST 650 \\
\hline 09.05 & McLure, M. & $\begin{array}{l}\text { ROYALTIES FOR REGIONS: ACCOUNTABILITY AND } \\
\text { SUSTAINABILITY }\end{array}$ \\
\hline 09.06 & Chen, A. and Groenewold, N. & $\begin{array}{l}\text { REDUCING REGIONAL DISPARITIES IN CHINA: AN } \\
\text { EVALUATION OF ALTERNATIVE POLICIES }\end{array}$ \\
\hline 09.07 & Groenewold, N. and Hagger, A. & $\begin{array}{l}\text { THE REGIONAL ECONOMIC EFFECTS OF IMMIGRATION: } \\
\text { SIMULATION RESULTS FROM A SMALL CGE MODEL. }\end{array}$ \\
\hline 09.08 & Clements, K. and Chen, D. & AFFLUENCE AND FOOD: SIMPLE WAY TO INFER INCOMES \\
\hline 09.09 & Clements, K. and Maesepp, M. & A SELF-REFLECTIVE INVERSE DEMAND SYSTEM \\
\hline 09.10 & Jones, C. & $\begin{array}{l}\text { MEASURING WESTERN AUSTRALIAN HOUSE PRICES: } \\
\text { METHODS AND IMPLICATIONS }\end{array}$ \\
\hline 09.11 & Siddique, M.A.B. & $\begin{array}{l}\text { WESTERN AUSTRALIA-JAPAN MINING CO-OPERATION: AN } \\
\text { HISTORICAL OVERVIEW }\end{array}$ \\
\hline 09.12 & Weber, E.J. & $\begin{array}{l}\text { PRE-INDUSTRIAL BIMETALLISM: THE INDEX COIN } \\
\text { HYPTHESIS }\end{array}$ \\
\hline 09.13 & McLure, M. & $\begin{array}{l}\text { PARETO AND PIGOU ON OPHELIMITY, UTILITY AND } \\
\text { WELFARE: IMPLICATIONS FOR PUBLIC FINANCE }\end{array}$ \\
\hline 09.14 & Weber, E.J. & $\begin{array}{l}\text { WILFRED EDWARD GRAHAM SALTER: THE MERITS OF A } \\
\text { CLASSICAL ECONOMIC EDUCATION }\end{array}$ \\
\hline 09.15 & Tyers, R. and Huang, L. & $\begin{array}{l}\text { COMBATING CHINA'S EXPORT CONTRACTION: FISCAL } \\
\text { EXPANSION OR ACCELERATED INDUSTRIAL REFORM }\end{array}$ \\
\hline 09.16 & $\begin{array}{l}\text { Zweifel, P., Plaff, D. and } \\
\text { Kühn, J. }\end{array}$ & $\begin{array}{l}\text { IS REGULATING THE SOLVENCY OF BANKS COUNTER- } \\
\text { PRODUCTIVE? }\end{array}$ \\
\hline 09.17 & Clements, K. & THE PHD CONFERENCE REACHES ADULTHOOD \\
\hline 09.18 & McLure, M. & $\begin{array}{l}\text { THIRTY YEARS OF ECONOMICS: UWA AND THE WA } \\
\text { BRANCH OF THE ECONOMIC SOCIETY FROM } 1963 \text { TO } 1992\end{array}$ \\
\hline 09.19 & Harris, R.G. and Robertson, P. & $\begin{array}{l}\text { TRADE, WAGES AND SKILL ACCUMULATION IN THE } \\
\text { EMERGING GIANTS }\end{array}$ \\
\hline 09.20 & $\begin{array}{l}\text { Peng, J., Cui, J., Qin, F. and } \\
\text { Groenewold, N. }\end{array}$ & STOCK PRICES AND THE MACRO ECONOMY IN CHINA \\
\hline 09.21 & Chen, A. and Groenewold, N. & $\begin{array}{l}\text { REGIONAL EQUALITY AND NATIONAL DEVELOPMENT IN } \\
\text { CHINA: IS THERE A TRADE-OFF? }\end{array}$ \\
\hline
\end{tabular}




\begin{tabular}{|c|c|c|}
\hline \multicolumn{3}{|c|}{$\begin{array}{c}\text { ECONOMICS DISCUSSION PAPERS } \\
2010\end{array}$} \\
\hline $\begin{array}{l}\text { DP } \\
\text { NUMBER }\end{array}$ & AUTHORS & TITLE \\
\hline 10.01 & Hendry, D.F. & $\begin{array}{l}\text { RESEARCH AND THE ACADEMIC: A TALE OF } \\
\text { TWO CULTURES }\end{array}$ \\
\hline 10.02 & McLure, M., Turkington, D. and Weber, E.J. & A CONVERSATION WITH ARNOLD ZELLNER \\
\hline 10.03 & $\begin{array}{l}\text { Butler, D.J., Burbank, V.K. and } \\
\text { Chisholm, J.S. }\end{array}$ & $\begin{array}{l}\text { THE FRAMES BEHIND THE GAMES: PLAYER'S } \\
\text { PERCEPTIONS OF PRISONER'S DILEMMA, } \\
\text { CHICKEN, DICTATOR, AND ULTIMATUM GAMES }\end{array}$ \\
\hline 10.04 & Harris, R.G., Robertson, P.E. and Xu, J.Y. & $\begin{array}{l}\text { THE INTERNATIONAL EFFECTS OF CHINA'S } \\
\text { GROWTH, TRADE AND EDUCATION BOOMS }\end{array}$ \\
\hline 10.05 & Clements, K.W., Mongey, S. and Si, J. & $\begin{array}{l}\text { THE DYNAMICS OF NEW RESOURCE PROJECTS } \\
\text { A PROGRESS REPORT }\end{array}$ \\
\hline 10.06 & Costello, G., Fraser, P., Groenewold, N. & $\begin{array}{l}\text { HOUSE PRICES, NON-FUNDAMENTAL } \\
\text { COMPONENTS AND INTERSTATE SPILLOVERS: } \\
\text { THE AUSTRALIAN EXPERIENCE }\end{array}$ \\
\hline 10.07 & Clements, $\mathrm{K}$. & $\begin{array}{l}\text { REPORT OF THE } 2009 \text { PHD CONFERENCE IN } \\
\text { ECONOMICS AND BUSINESS }\end{array}$ \\
\hline 10.08 & Robertson, P.E. & $\begin{array}{l}\text { INVESTMENT LED GROWTH IN INDIA: HINDU } \\
\text { FACT OR MYTHOLOGY? }\end{array}$ \\
\hline 10.09 & Fu, D., Wu, Y., Tang, Y. & $\begin{array}{l}\text { THE EFFECTS OF OWNERSHIP STRUCTURE AND } \\
\text { INDUSTRY CHARACTERISTICS ON EXPORT } \\
\text { PERFORMANCE }\end{array}$ \\
\hline 10.10 & $\mathrm{Wu}, \mathrm{Y}$. & $\begin{array}{l}\text { INNOVATION AND ECONOMIC GROWTH IN } \\
\text { CHINA }\end{array}$ \\
\hline 10.11 & Stephens, B.J. & $\begin{array}{l}\text { THE DETERMINANTS OF LABOUR FORCE } \\
\text { STATUS AMONG INDIGENOUS AUSTRALIANS }\end{array}$ \\
\hline 10.12 & Davies, $\mathrm{M}$. & $\begin{array}{l}\text { FINANCING THE BURRA BURRA MINES, SOUTH } \\
\text { AUSTRALIA: LIQUIDITY PROBLEMS AND } \\
\text { RESOLUTIONS }\end{array}$ \\
\hline 10.13 & Tyers, R., Zhang, Y. & APPRECIATING THE RENMINBI \\
\hline 10.14 & Clements, K.W., Lan, Y., Seah, S.P. & $\begin{array}{l}\text { THE BIG MAC INDEX TWO DECADES ON } \\
\text { AN EVALUATION OF BURGERNOMICS }\end{array}$ \\
\hline 10.15 & Robertson, P.E., Xu, J.Y. & $\begin{array}{l}\text { IN CHINA'S WAKE: } \\
\text { HAS ASIA GAINED FROM CHINA'S GROWTH? }\end{array}$ \\
\hline 10.16 & Clements, K.W., Izan, H.Y. & $\begin{array}{l}\text { THE PAY PARITY MATRIX: A TOOL FOR } \\
\text { ANALYSING THE STRUCTURE OF PAY }\end{array}$ \\
\hline 10.17 & Gao, G. & WORLD FOOD DEMAND \\
\hline 10.18 & $\mathrm{Wu}, \mathrm{Y}$. & $\begin{array}{l}\text { INDIGENOUS INNOVATION IN CHINA: } \\
\text { IMPLICATIONS FOR SUSTAINABLE GROWTH }\end{array}$ \\
\hline 10.19 & Robertson, P.E. & DECIPHERING THE HINDU GROWTH EPIC \\
\hline
\end{tabular}

